\title{
MANEJO DA FERTIRRIGAÇÃO E CONTROLE DA SALINIDADE NA CULTURA DO PIMENTÃO UTILIZANDO EXTRATORES DE SOLUÇÃO DO SOLO
}

\author{
ÊNIO FARIAS DE FRANÇA E SILVA
}

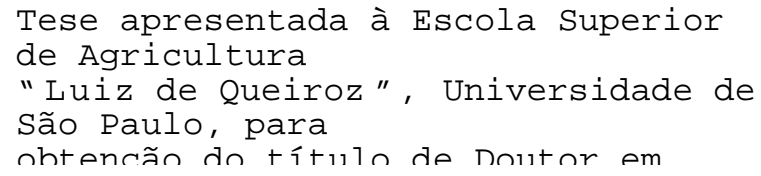

PIRACICABA

Estado de São Paulo - Brasil

Fevereiro - 2002 


\title{
MANEJO DA FERTIRRIGAÇÃO E CONTROLE DA SALINIDADE NA CULTURA DO PIMENTÃO UTILIZANDO EXTRATORES DE SOLUÇÃO DO SOLO
}

\section{ÊNIO FARIAS DE FRANÇA E SILVA}

Engenheiro Agrícola

Orientador: Prof. Dr. SERGIO NASCIMENTO DUARTE

\author{
Tese apresentada à Escola Superior de Agricultura \\ "Luiz de Queiroz", Universidade de São Paulo, para \\ obtenção do título de Doutor em Agronomia, Área de \\ Concentração: Irrigação e Drenagem.
}

PIRACICABA

Estado de São Paulo - Brasil

Fevereiro - 2002 
Dados Internacionais de Catalogação na Publicação (CIP) DIVISÃO DE BIBLIOTECA E DOCUMENTAÇÃO - ESALQ/USP

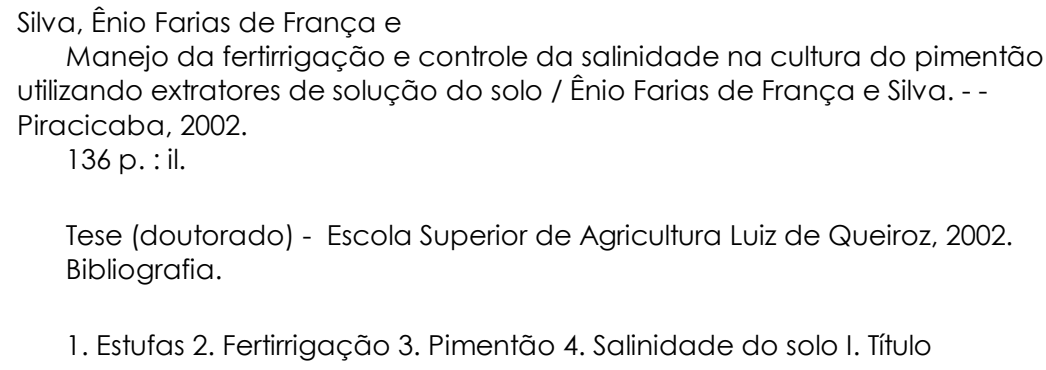

CDD 635.643 
Aos meus pais Sócrates Otávio de França

e Silva e Maria do Socorro Farias de

França e Silva, com todo amor

\section{OFEREÇO}

A minha amada esposa Renata Maia Araújo

de França e aos meus filhos

DEDICO 


\section{AGRADECIMENTOS}

- À DEUS, pela vida e por ter me dado inspiração e persistência nos momentos necessários;

- Ao Departamento de Engenharia Rural da Escola Superior de Agricultura "Luiz de Queiroz"/USP, pelo suporte disponibilizado;

- Ao Curso de Pós-Graduação em Irrigação e Drenagem pela oportunidade concedida para realização do curso e desenvolvimento do trabalho de tese;

- A CAPES pela concessão da bolsa de estudos;

- A Fundação de Apoio à Pesquisa do Estado de São Paulo pelo auxílio financeiro para o desenvolvimento da pesquisa;

- Ao Professor Sergio Nascimento Duarte pela orientação, estímulo, confiança depositada e sobre tudo pela amizade;

- Ao Professor Hans Raj Gheyi pelo incentivo, apoio técnico e emocional durante todo o tempo de realização do curso;

- Aos professores Antônio Enedi Boaretto, Rubens Duarte Coelho, Marcos Vinícius Folegatti pelas valiosas contribuições;

- Aos colegas de curso, em especial ao Dr. Anderson Soares Pereira, Flávio Favaro Blanco, Jarbas Honório de Miranda, Luiz Fernando Campeche e Maurício Coelho, pela ajuda e amizade durante o curso;

- Aos funcionários do Departamento de Engenharia Rural Sr. Antônio Gozzo, Antônio Cezar Rocha, Hélio Lemos e Gilmar Grigolon pela colaboração;

-A todos que direta ou indiretamente contribuíram para realização desse trabalho. 


\section{SUMÁRIO}

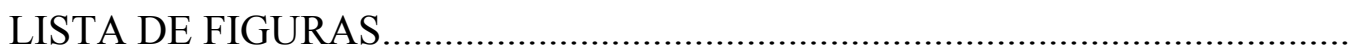

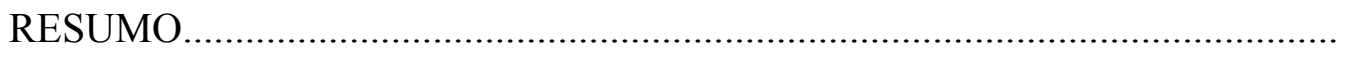

SUMMARY....

1 INTRODUÇÃO...

Página

viii

xiv

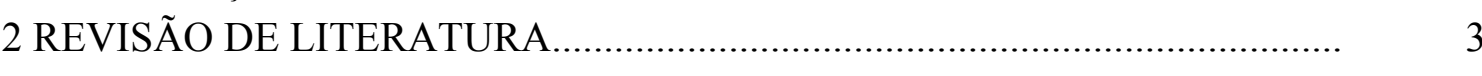

$2.1 \mathrm{O}$ processo de salinização dos solos.............................................................. 3

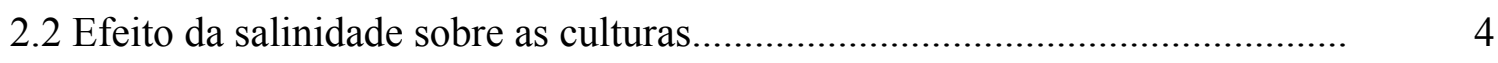

2.3 O cultivo sob ambiente protegido: vantagens e a salinização dos solos............ 7

2.4 Métodos de determinação da salinidade do solo............................................. 9

Metodologias para extração da solução do solo e o monitoramento de sua concentração iônica................................................................................ $\quad 10$

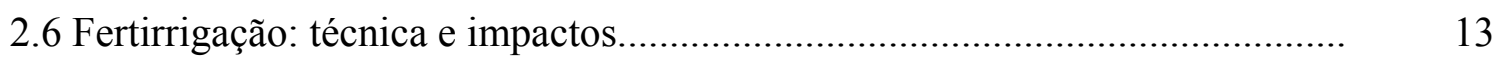

2.7 Aspectos nutricionais e suas relações com a salinidade.................................... 15

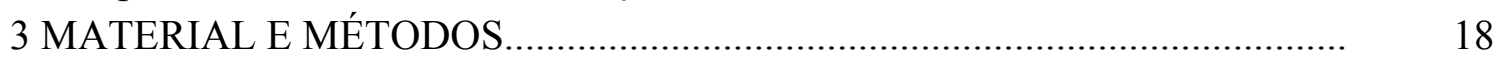

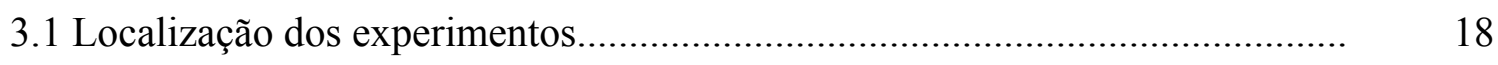

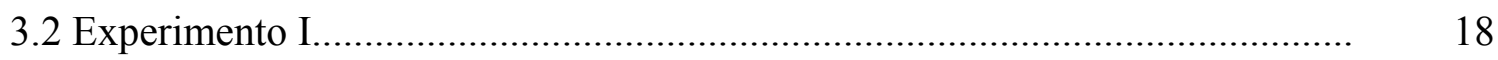

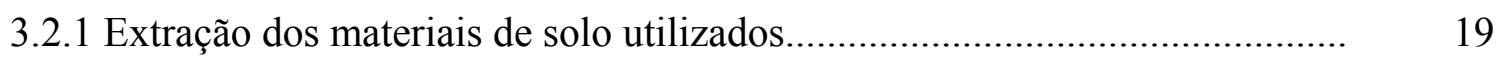

3.2.2 Caracterização físico-hídrica dos materiais de solo..................................... 19

3.2.3 Caracterização química dos materiais de solo............................................ 20

3.2.4 Construção das curvas de salinização.......................................................... 20

3.2.5 Testes iniciais dos extratores na determinação da salinidade do solo............ 21

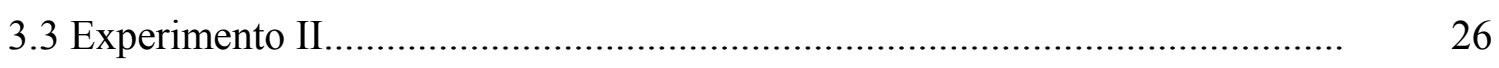

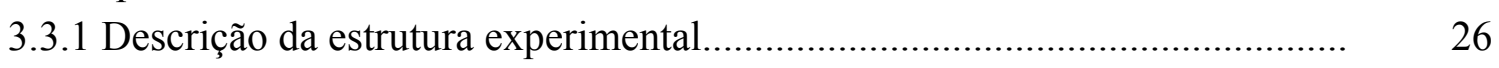

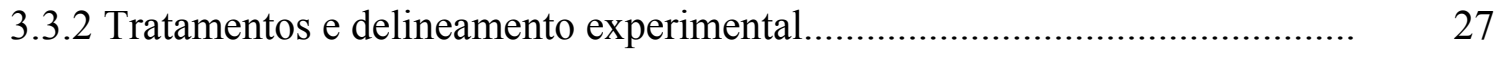

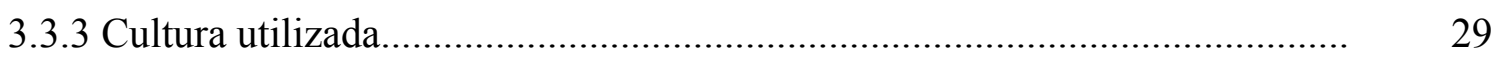

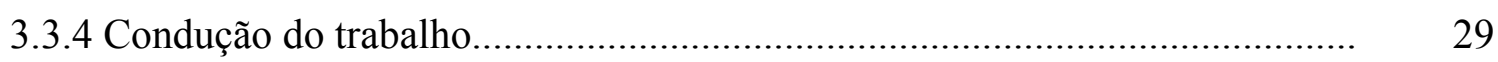

3.3.4.1 Acondicionamento e salinização dos materiais de solo............................. 29

3.3.4.2 Transplantio e condução das plantas........ 
3.3.4.3 Manejo da irrigação................................................................................. 31

3.3.4.4 Adubação.................................................................................... 32

3.3.4.5 Extração da solução do solo....................................................................... 33

3.3.5 Variáveis agroclimáticas e demanda hídrica................................................. 34

3.3.6 Variáveis relacionadas à cultura................................................................ 36

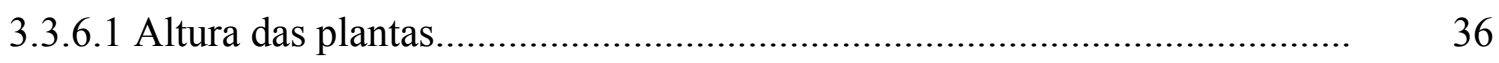

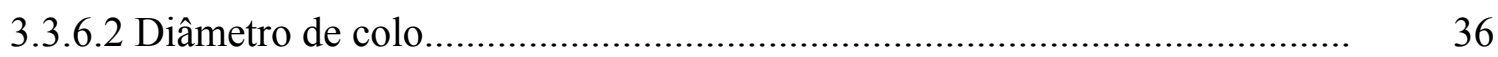

3.3.6.3 Rendimento e componentes de produção.................................................... 36

3.3.6.4 Massa seca dos frutos........................................................................ 37

3.3.6.5 Massa verde e seca da parte aérea das plantas........................................... 37

3.3.6.6 Níveis de nitrato e potássio na seiva da planta.............................................. 37

3.3.6.7 Teores de macronutrientes, sólidos solúveis totais e acidez nos frutos...... 38

3.3.6.8 Ajustamento osmótico das plantas.......................................................... 39

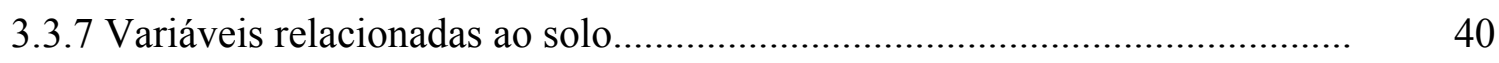

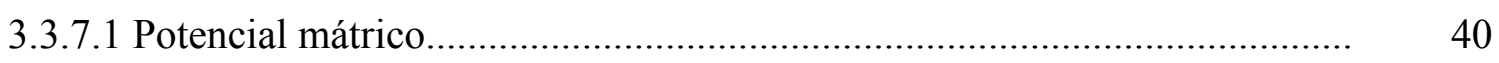

3.3.7.2 Condutividade elétrica, $\mathrm{pH}$ e concentração iônica na solução do solo....... 41

3.3.8 Análises estatística dos resultados................................................................ 41

4 RESULTADOS E DISCUSSÃO.............................................................

4.1 Resultados dos testes iniciais (Experimento I)............................................... 43

4.1.1 Propriedades físico-hídricas e químicas dos materiais de solo utilizados...... $\quad 43$

4.1.1.1 Material de solo retirado do Latossolo Vermelho Amarelo......................... 43

4.1.1.2 Material de solo retirado da Terra Roxa Estruturada................................... 44

4.1.2 Curvas de salinização dos solos................................................................

4.1.3 Teste preliminar dos extratores na determinação da salinidade do solo........ $\quad 49$

4.2 Resultados do cultivo em estufa plástica (Experimento II).............................. 54

4.2.1. Aspectos químicos na solução do solo........................................................... 54

4.2.1.1 Aspectos químicos para o Latossolo Vermelho Amarelo (franco- 64 arenoso)

4.2.1.2 Aspectos químicos para Terra Roxa Estruturada (franco-argiloso)............ 58

4.2.2 Monitoramento da salinidade do solo......................................................... 60

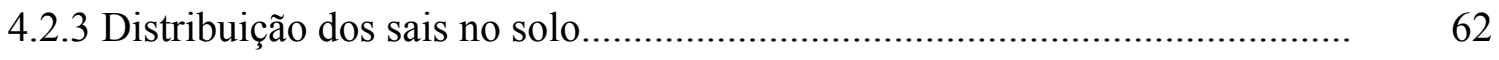

Comparação entre medidas de condutividade elétrica e concentração iônica determinadas nas soluções extraídas pela cápsula porosa e no extrato de saturação

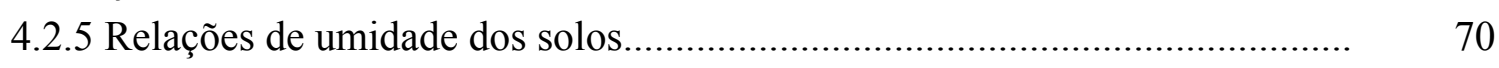

4.2.6 Características vegetativas....................................................................... 


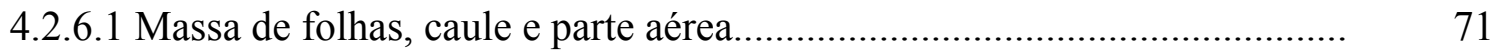

4.2.6.2 Altura de plantas............................................................................... $\quad 76$

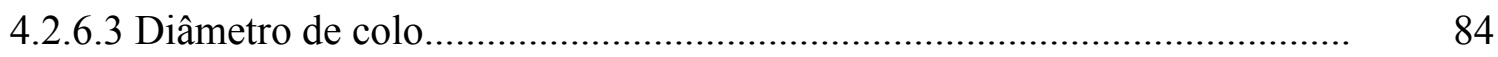

4.2.7 Produção e componentes de produção......................................................... 89

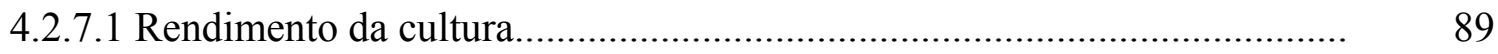

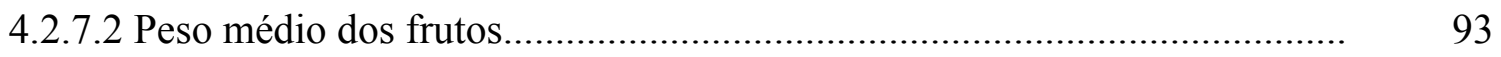

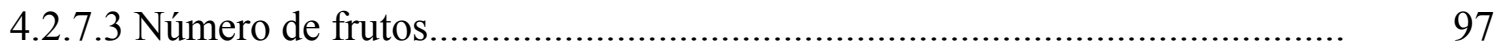

4.2.7.4 Porcentagem de matéria seca e espessura de casca dos frutos................... 101

4.2.7.5 Diâmetro e comprimento médio dos frutos.............................................. 104

4.2.7.6 Variáveis de qualidade e teores de macronutrientes nos frutos.................. 107

4.2.8 Teores de potássio e nitrato na seiva da planta........................................... 110

Comparação entre os valores de potássio e nitrato determinados em laboratório e em testes rápidos

4.2.10 Demanda hídrica da cultura sob condições salinas.................................... 115

4.2.11 Tolerância da cultura do pimentão à salinidade........................................ 118

Ajustamento osmótico do pimentão aos diferentes níveis de salinidade do

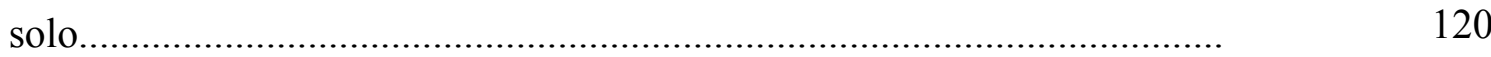

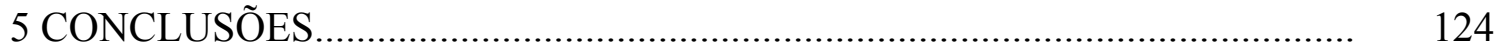

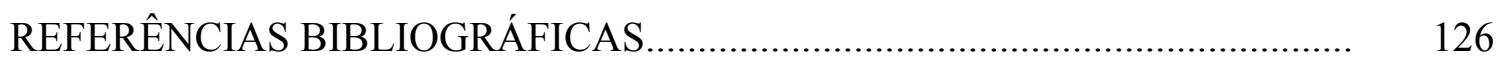




\section{LISTA DE FIGURAS}

1 Disposição dos vasos no experimento conduzido em laboratório..................... 24

2 Extração da solução do solo por aplicação de vácuo.......................................... 24

3 A) Vista frontal das estufas agrícolas utilizadas no experimento II ; B) Detalhe das janelas frontais..................................................................... 27

4 Croquis da área experimental.................................................................. 28

5 Linha lateral de plantio para efeito de bordadura........................................... 31

6 Equipamentos para aquisição de dados agroclimáticos: A) Datalogger (CR10); B) Mini tanque evaporimétrico automatizado; C) Psicrômetro com ventilação forçada; D) Radiômetros de radiação líquida, global e fotossinteticamente ativa.

7 Equipamentos para determinação da concentração iônica na seiva da planta. $\quad 38$

8 Equipamentos utilizados na determinação das curvas pressão volume............ $\quad 40$

9 Leitura da tensão da água do solo por meio de tensímetro eletrônico de punção

10 Curva característica de retenção da água no Latossolo Vermelho Amarelo

11 rva característica de retenção da água na Terra Roxa Estruturada...............

12 Curva de salinização artificial para o Latossolo Vermelho Amarelo............... 46

13 Curva de salinização artificial para a Terra Roxa Estruturada.......................... 46

14 Relação entre a condutividade elétrica (CE) do extrato da pasta de saturação calculada teoricamente e medida experimentalmente para o Latossolo Vermelho Amarelo.

15 Relação entre a condutividade elétrica (CE) do extrato da pasta de saturação calculada teoricamente e medida experimentalmente para a Terra Roxa Estruturada.

16 Condutividade elétrica, ao longo dos dias, da solução do Latossolo Vermelho Amarelo extraída com o extrator de cápsula porosa.

17 Relação entre os valores de condutividade elétrica do extrato de saturação (CEes) e condutividade elétrica da suspensão 1:2 (CE 1:2) para o Latossolo Vermelho Amarelo. 
18 Relação entre os valores de condutividade elétrica do extrato de saturação medida e estimada a partir da condutividade elétrica da suspensão 1:2, com correção em função da umidade para o Latossolo Vermelho Amarelo.

19 Relação entre os valores de condutividade elétrica do extrato de saturação (CEes) e condutividade elétrica da solução obtida com extrator de cápsula (CEscp) para o Latossolo Vermelho Amarelo.

20 Relação entre os valores de condutividade elétrica do extrato de saturação, medida e estimada a partir da condutividade elétrica da solução obtida com extrator de cápsula com correção em função da umidade para o Latossolo Vermelho Amarelo.

21 Diagrama de dispersão e equação de ajuste para o solo franco-arenoso entre: (A) condutividade elétrica, (B) potássio, (C) cálcio, (D) magnésio, (E) enxofre e $(F)$ fósforo na solução do solo e a salinidade inicial do solo para os diferentes manejos de fertirrigação.

22 Diagrama de dispersão e equação de ajuste para o solo franco-arenoso entre o nitrato na solução do solo e a salinidade inicial do solo para: (A) o manejo de fertirrigação tradicional e (B) o manejo de fertirrigação controlado.....

23 Diagrama de dispersão e equação de ajuste para o solo franco-arenoso entre o pH da solução do solo e a salinidade inicial do solo para para os diferentes manejos de fertirrigação

24 Diagrama de dispersão e equação de ajuste para o solo franco-argiloso entre: (A) condutividade elétrica, (B) potássio, (C) cálcio, (D) magnésio, (E) enxofre, (F) fósforo e $(G)$ nitrato na solução do solo e a salinidade inicial do solo para os diferentes manejos de fertirrigação.

25 Diagrama de dispersão e equação de ajuste para o solo franco-argiloso entre o pH da solução do solo e a salinidade inicial do solo para os diferentes manejos de fertirrigação.

26 Valores de condutividade elétrica na solução do solo ao longo do ciclo da cultura para: (A) solo franco-arenoso com manejo de fertirrigação tradicional, (B) solo franco-argiloso com manejo de fertirrigação tradicional, (C) solo franco-arenoso com manejo de fertirrigação controlado, (D) solo franco-argiloso com manejo de fertirrigação controlado

27 Distribuição espacial da condutividade elétrica nos vasos com salinidade inicial de $5 \mathrm{dS} \mathrm{m}^{-1}$ no solo franco-arenoso nas profundidades de (A) $0-10$, (B) $10-20$, (C) $20-30$ e (D) $30-40 \mathrm{~cm}$.

28 Distribuição espacial da condutividade elétrica nos vasos com salinidade inicial de $5 \mathrm{dS} \mathrm{m} \mathrm{m}^{-1}$ no solo franco-argiloso nas profundidades de (A) $0-10$, (B) $10-20$, (C) $20-30$ e (D) $30-40 \mathrm{~cm}$

29 Relação entre os valores de condutividade elétrica do extrato de saturação, medido e estimado a partir da condutividade elétrica da solução obtida com extrator de cápsula com correção em função da umidade para ambos os solos utilizados no experimentoII 
30 Relação entre os valores de: (A) $\mathrm{K}$, (B) $\mathrm{NO}_{3}$, (C) $\mathrm{Ca}$, (D) $\mathrm{Mg}$, (E) S e (F) P no extrato de saturação, medido e estimado a partir das concentrações correspondentes na solução obtida com extrator de cápsula com correção em função da umidade para ambos os solos utilizados no experimento II......

31 Potencial mátrico médio para os diferentes tratamentos ao longo do ciclo de pimentão

2 Porosidade média do solo livre de água (PLA) para os diferentes tratamentos ao longo do ciclo de pimentão.

33 Diagrama de dispersão e equação de ajuste para o solo franco-arenoso entre: (A) massa seca de folhas com manejo tradicional da fertirrigação, (B) massa seca de folhas com manejo controlado da fertirrigação, (C) massa seca do caule para ambos os manejos de fertirrigação, (D) massa seca da parte aérea com manejo tradicional da fertirrigação e (E) massa seca da parte aérea com manejo controlado da fertirrigação e a salinidade inicial do solo.

34 Diagrama de dispersão e equação de ajuste para o solo franco-arenoso entre: (A) massa verde de folhas com manejo tradicional da fertirrigação, (B) massa verde de folhas com manejo controlado da fertirrigação, (C) massa verde do caule para ambos os manejos de fertirrigação e (D) massa verde da parte aérea para ambos os manejos de fertirrigação e a salinidade inicial do solo.

35 Diagrama de dispersão e equação de ajuste para o solo franco-argiloso entre: (A) massa seca de folhas, (B) massa seca de caule, (C) massa seca da parte aérea, (D) massa verde de folhas, (E) massa verde do caule e (F) massa verde da parte aérea, para os ambos manejos e a salinidade inicial do solo.

36 Altura de plantas para os diferentes níveis de salinidade: (A) manejo tradicional de fertirrigação e (B) manejo controlado de fertirrigação para o solo franco-arenoso...

37 Diagrama de dispersão e equação de ajuste para o solo franco-arenoso entre: (A) altura de planta aos 30 DAT com o manejo tradicional da fertirrigação, (B) altura de planta aos 30 DAT com o manejo controlado da fertirrigação, (C) altura de planta aos 70 DAT para ambos os manejos da fertirrigação, (D) altura de planta aos 130 DAT para ambos os manejos da fertirrigação e (E) altura de planta aos 150 DAT para ambos os manejos da fertirrigação e a salinidade inicial do solo.

38 Altura de plantas para os diferentes níveis de salinidade: (A) manejo tradicional de fertirrigação e (B) manejo controlado de fertirrigação para o solo franco-argiloso. 
39 Diagrama de dispersão e equação de ajuste para o solo franco-argiloso entre: (A) altura de planta aos 30 DAT para ambos os manejos da fertirrigação, (B) altura de planta aos 70 DAT com o manejo tradicional da fertirrigação, (C) altura de planta aos 70 DAT com o manejo controlado da fertirrigação, (D) altura de planta aos 130 DAT com o manejo tradicional da fertirrigação, (E) altura de planta aos 130 DAT com o manejo controlado da fertirrigação e (F) altura de planta aos 150 DAT para ambos os manejos de fertirrigação e a salinidade inicial do solo..

40 Diâmetro de colo para os diferentes níveis de salinidade: (A) manejo tradicional de fertirrigação e (B) manejo controlado de fertirrigação para o solo franco-arenoso.

41 Diagrama de dispersão e equação de ajuste para o solo franco-arenoso entre: (A) diâmetro de colo aos 30 DAT para ambos os manejos da fertirrigação, (B) diâmetro de colo aos 70 DAT para ambos os manejos da fertirrigação, (C) diâmetro de colo aos 130 DAT para ambos os manejos da fertirrigação, (D) diâmetro de colo aos 150 DAT com o manejo tradicional da fertirrigação, e (E) diâmetro de colo aos 150 DAT com o manejo controlado da fertirrigação e a salinidade inicial do solo.

42 Diâmetro de colo para os diferentes níveis de salinidade: (A) manejo tradicional de fertirrigação e (B) manejo controlado de fertirrigação para o solo franco-argiloso...

43 Diagrama de dispersão e equação de ajuste para o solo franco-argiloso entre: (A) diâmetro de colo aos 30 DAT para ambos os manejos da fertirrigação, (B) diâmetro de colo aos 70 DAT com manejo tradicional da fertirrigação, (C) diâmetro de colo aos 70 DAT com manejo controlado da fertirrigação, (D) diâmetro de colo aos 130 DAT para ambos os manejos da fertirrigação (E) diâmetro de colo aos 150 DAT com o manejo tradicional da fertirrigação, e (F) diâmetro de colo aos 150 DAT com o manejo controlado da fertirrigação e a salinidade inicial do solo.

44 Diagrama de dispersão e equação de ajuste para o solo franco-arenoso entre o rendimento até: (A) 78 DAT para ambos os manejos de fertirrigação, (B) 114 DAT para o manejo tradicional da fertirrigação, (C) 114 DAT para o manejo controlado da fertirrigação e (D) 153 DAT para ambos os manejos de fertirrigação e a salinidade inicial do solo.

45 Diagrama de dispersão e equação de ajuste para o solo franco-argiloso entre o rendimento até: (A) 78 DAT, (B) 114 DAT e (C) 153 DAT para os diferentes manejos de fertirrigação e a salinidade inicial do solo.

46 Diagrama de dispersão e equação de ajuste para o solo franco-arenoso entre o peso médio de frutos até: (A) 78 DAT para o manejo tradicional da fertirrigação, (B) 78 DAT para o manejo controlado da fertirrigação, (C) 114 DAT para o manejo tradicional da fertirrigação, (D) 114 DAT para o manejo controlado da fertirrigação, (E)153 DAT para o manejo tradicional da fertirrigação e (F)153 DAT para o manejo controlado da fertirrigação e a salinidade inicial do solo. 
47 Diagrama de dispersão e equação de ajuste para o solo franco-argiloso entre o peso médio de frutos até: (A) 78 DAT, (B) 114 DAT e (C) 153 DAT para os diferentes manejos de fertirrigação e a salinidade inicial do solo......

48 Diagrama de dispersão e equação de ajuste para o solo franco-arenoso entre o número de frutos aos: (A) 78 DAT, (B) 114 DAT e (C) 153 DAT para os diferentes manejos de fertirrigação e a salinidade inicial do solo.

49 Diagrama de dispersão e equação de ajuste para o solo franco-argiloso entre o número de frutos aos: (A) 78 DAT, (B) 114 DAT e (C) 153 DAT para os diferentes manejos de fertirrigação e a salinidade inicial do solo.

50 Diagrama de dispersão e equação de ajuste para o solo franco-arenoso entre: (A) porcentagem de matéria seca e (B) espessura de casca e a salinidade inicial do solo.

51 Diagrama de dispersão e equação de ajuste para o solo franco-argiloso entre: (A) porcentagem de matéria seca e (B) espessura de casca e a salinidade inicial do solo.

52 Diagrama de dispersão e equação de ajuste para o solo franco-arenoso entre: (A) diâmetro de frutos com o manejo tradicional da fertirrigação, (B) diâmetro de frutos com o manejo controlado da fertirrigação, (C) comprimemto de frutos com o manejo tradicional da fertirrigação, (D) comprimento de frutos com o manejo controlado da fertirrigação e a salinidade inicial do solo.

53 Diagrama de dispersão e equação de ajuste para o solo franco-argiloso entre: (A) diâmetro de frutos e (B) comprimento de frutos para ambos os manejos de fertirrigação e a salinidade inicial do solo.

54 Quantificação do: (A) sólidos solúveis e (B)acidez titulável para os frutos dos diferentes tratamentos.

55 Concentração dos macronutrientes: $(\mathrm{A})$ nitrogênio, $(\mathrm{B})$ potássio, $(\mathrm{C})$ cálcio, (D) magnésio, (E) enxofre e $(F)$ fósforo nos frutos dos diferentes tratamentos.

56 Diagrama de dispersão e equação de ajuste para o solo franco-arenoso entre: (A) concentração de potássio na seiva com manejo tradicional da fertirrigação, (B) concentração de potássio na seiva com manejo controlado da fertirrigação e (C) concentração de nitrato na seiva para ambos os manejos de fertirrigação e a salinidade inicial do solo.

57 Diagrama de dispersão e equação de ajuste para o solo franco-argiloso entre: (A) concentração de potássio na seiva com manejo tradicional da fertirrigação, (B) concentração de potássio na seiva com manejo controlado da fertirrigação e (C) concentração de nitrato na seiva com manejo tradicional da fertirrigação e (D) concentração de nitrato na seiva com manejo controlado da fertirrigação e a salinidade inicial do solo.

58 Relação entre os valores de: (A) potássio e (B) nitrato determinados em laboratório e em campo por meio de testes rápidos.

59 Consumo hídrico médio para os solos: (A) franco-arenoso e (B) francoargiloso. 
60 Coeficientes da cultura para diferentes fases fenológicas.

61 (A) Evapotranspiração de referência pelo tanque evaporimétrico (ETL), por Penman-Montheith (ETPM) e pelo método da radiação (ETRad); da cultura (Etc) e real (Etr) para os diferentes níveis de salinidade do solo francoarenoso e (B) temperatura máxima, média e mínima ao longo do ciclo..........

62 Curva de tolerância do híbrido de pimentão "Elisa" à salinidade a partir dos resultados obtidos no presente experimento.

63 Curva Pressão volume obtida em folhas provenientes de planta de pimentão cultivada em solo franco-arenoso com salinidade do correspondente a $1 \mathrm{dS} \mathrm{m}^{-1}$

64 Curva Pressão volume obtida em folhas provenientes de planta de pimentão cultivada em solo franco-arenoso com salinidade do correspondente a $8 \mathrm{dS} \mathrm{m}^{-1}$

65 Curva Pressão volume obtida em folhas provenientes de planta de pimentão cultivada em solo franco-argiloso com salinidade do correspondente a $1 \mathrm{dS} \mathrm{m}^{-1}$

66 Curva Pressão volume obtida em folhas provenientes de planta de pimentão cultivada em solo franco-argiloso com salinidade do correspondente a $8 \mathrm{dS} \mathrm{m}^{-1}$ 


\title{
MANEJO DA FERTIRRIGAÇÃO E CONTROLE DA SALINIDADE NA CULTURA DO PIMENTÃO UTILIZANDO EXTRATORES DE SOLUÇÃO DO SOLO
}

\author{
Autor: ÊNIO FARIAS DE FRANÇA E SILVA \\ Orientador: Prof. Dr. SERGIO NASCIMENTO DUARTE
}

\section{RESUMO}

O presente trabalho foi realizado com o objetivo de avaliar a utilização de extratores providos de cápsulas cerâmicas no manejo da fertirrigação e no controle do processo de salinização em um cultivo de pimentão (Capsicum annuum L.), ocasionado pelo acúmulo de fertilizantes aplicados em excesso, a partir de um monitoramento da condutividade elétrica da solução do solo e de nutrientes específicos (potássio e nitrato) pelo uso de testes rápidos. Foram analisados os efeitos da técnica proposta no crescimento vegetativo e no rendimento obtido no cultivo de pimentão sob ambiente protegido. Utilizaram-se dois solos com texturas distintas, um franco arenoso e o outro franco argiloso, ambos contidos em vasos de $62 \mathrm{~L}$ e salinizados artificialmente a diferentes níveis de condutividade elétrica no extrato de saturação, variando de 1 até $9 \mathrm{dS} \mathrm{m}^{-1}$. Os resultados obtidos demonstraram que com a técnica proposta pode-se monitorar a concentração iônica da solução do solo além de possibilitar a determinação dos íons potássio e nitrato com alta precisão, cálcio e magnésio com precisão satisfatória e que não é recomendado a determinação da concentração de enxofre e fósforo na solução do solo. Observou-se também que o controle dessa solução em níveis desejados proporcionou um efeito benéfico no cultivo do pimentão além de evitar desequilíbrios 
iônicos e salinização dos solos. Os íons nitrato e potássio podem ser determinados e monitorados ao longo do ciclo da cultura pelo uso de testes rápidos. Os níveis crescentes de salinidade inicial do solo ocasionaram para o solo franco-arenoso uma redução no rendimento da cultura, bem como, nas variáveis vegetativas e consumo hídrico. Entretanto, para o solo franco-argiloso ocorreu uma tendência de incremento das variáveis de crescimento e produção com o aumento da salinidade inicial do solo, fato esse, atribuído à redução do efeito da salinidade inicial sobre as plantas de pimentão, ocasionada possivelmente pela distribuição de sais no solo. Os manejos da fertirrigação não proporcionaram efeitos discrepantes nas variáveis relacionadas ao crescimento e produção do pimentão, em virtude da recomendação e marcha de absorção de nutrientes escolhidos para o manejo tradicional adaptar-se bem a extração de nutrientes pela cultura. 


\title{
FERTIGATION MANAGEMENT AND SALINITY CONTROL IN BELL PEPER USING SOIL SOLUTION EXTRACTORS
}

\author{
Author: ÊNIO FARIAS DE FRANÇA E SILVA \\ Adviser: Prof. Dr. SERGIO NASCIMENTO DUARTE
}

\section{SUMMARY}

The objective of this study was evaluating the use of extractors provided of ceramic cups on fertigation management and on the control of salinization in cultivation of bell pepper (Capsicum annuum L.), caused by excessive fertilization, by means of monitoring the electrical conductivity of soil solution and specific nutrients (potassium and nitrate) using quick tests. The effects of the proposed technique on vegetative development and yield of bell pepper in greenhouse were analyzed. Two soils with different textures were used, sandy-loam and clay-loam, both packed in pots of $62 \mathrm{~L}$, which were artificially salinized in order to obtain electrical conductivities of the saturation extract varying from 1 to $9 \mathrm{dS} \mathrm{m}^{-1}$. Results showed that the proposed technique allows monitoring of ionic concentration of soil solution and permits the determination of the $\mathrm{K}$ and $\mathrm{NO}_{3}$ with high accuracy, $\mathrm{Ca}$ and $\mathrm{Mg}$ with satisfactory accuracy and are not recommended for determination of the $\mathrm{S}$ and $\mathrm{P}$ concentration in soil solution. Maintaining the nutrients concentration and electrical conductivity of the soil solution at desired levels provide many advantages for the cultivation of bell pepper in greenhouse besides avoiding ionic unbalances and soil salinization. $\mathrm{NO}_{3}$ and $\mathrm{K}$ concentrations may be determined and monitored along of crop season by quick test. The crescent levels of initial soil salinity decreased yield, vegetative variables and water uptake for the sandy loam soil. However, 
for the clay-loam soil an increasing tendency occurred for growing variables and yield with increasing initial soil salinity, probably because the low effect of initial soil salinity on crop development, which was caused by the salts distribution pattern in the soil. The different fertigation management did not produced disagreeing effects on variables related to crop growth and yield, because the chosen recommendation and uptake rate curve for the traditional fertigation management supplied the crop nutritional requirements. 


\section{INTRODUÇÃO}

A aplicação excessiva de fertilizantes via água de irrigação em cultivos de olerícolas sob ambiente protegido, pode ocasionar a salinização dos solos e desequilíbrios nutricionais nas plantas, em virtude principalmente de antagonismos iônicos. Estes fatores atuam diretamente na redução da produtividade das culturas, bem como na queda da qualidade do produto final. As recomendações de adubação tradicionais para cultivo em campo aberto adaptadas para serem utilizadas em ambiente protegido, via fertirrigação, na maioria das vezes, tendem a fornecer uma quantidade de nutrientes além daquela exigida pela cultura, visto a possibilidade de lixiviação desses ocasionada por precipitações, o que não ocorre em cultivos sob estufas plásticas.

Esses nutrientes aplicados em excesso não são absorvidos pela cultura e acumulam-se no solo ou são perdidos por percolação. Neste caso, a recomendação da aplicação de lâminas de lixiviação não parece ser a solução mais adequada, visto que os sais causadores destes processos foram adquiridos por investimento financeiro.

A manutenção da concentração de íons na solução do solo a níveis nos quais a salinidade apresente valores inferiores ao máximo tolerado pela cultura e superiores ao mínimo necessário para sua nutrição torna-se uma opção mais técnica e menos agressiva ao meio ambiente. O monitoramento da concentração exige determinações constantes e a freqüência dessas determinações pode ser elevada se o ciclo da cultura for curto, assim sendo, a utilização de extratores de solução do solo surge como uma alternativa viável.

Várias vantagens podem ser relacionadas ao método dos extratores de cápsula porosa na determinação e monitoramento da concentração iônica: a quantidade de íons na solução extraída pelos extratores é mais próxima da quantidade na solução do 
solo que é absorvida pela planta e os solutos dissolvidos serão aproximadamente os mesmos; a amostragem é sistemática, sempre no mesmo ponto e não destrutiva; a aferição da condutividade elétrica é praticamente instantânea.

Visto as vantagens relacionadas à obtenção da solução do solo, por meio de cápsulas porosas e da complexidade da determinação da concentração iônica da solução do solo com precisão, tornam-se necessários estudos visando avaliar a precisão e possibilidade da utilização da metodologia no auxílio ao manejo da fertirrigação e controle do processo de salinização do solo.

Dessa forma, esta técnica de obtenção da solução por intermédio de cápsulas porosas foi avaliada como uma alternativa a um custo reduzido, capaz de ser aplicada a situações de campo. Entretanto, dada às minúcias do sistema, é necessário calibrar o método para condições de cultivo específico.

Assim sendo, enumeraram-se as hipóteses abaixo:

1) É possível a utilização de cápsulas cerâmicas, como extratores de solução do solo, no auxílio ao manejo da fertirrigação, determinando a concentração de íons específicos.

2) O monitoramento da solução auxilia na tomada de decisão das quantidades de fertilizantes a serem aplicados no momento da fertirrigação e dessa forma evita a deficiência de nutrientes ou desperdício de fertilizantes.

3) A metodologia proposta é capaz de evitar a salinização do solo e/ou toxidez e desequilíbrios nutricionais das plantas causados pelo excesso de sais na solução do solo. 


\section{REVISÃO DE LITERATURA}

\subsection{O processo de salinização dos solos}

A salinização dos solos pode ter origem natural ou ser induzida pelo homem. Os processos naturais associados diretamente a pedogênese são os responsáveis pela maior parte da área salinizada no mundo (Tanji, 1990). Entretanto, a salinização causada pela ação do homem é a que traz maior impacto econômico, pois ocorre em áreas onde se realizou investimento de capital.

A salinização induzida pelo homem, denominada de secundária, está geralmente associada ao manejo inadequado da irrigação, ocorrendo principalmente em regiões áridas ou semi-áridas. Os fatores diretamente responsáveis pela salinização dos solos em áreas irrigadas são:

a) uso de água de irrigação com alta concentração salina;

b) elevação do lençol freático causada pelo manejo inadequado da irrigação, pelas perdas de água por infiltração em canais e reservatórios, e por deficiência de drenagem (Smedema, 1988);

c) aplicação de fertilizantes, de forma excessiva e pouco parcelada no decorrer do período, induzindo stress osmótico ao sistema radicular.

De maneira geral, o processo de salinização pode ser evitado ou desacelerado caso ocorram precipitações pluviométricas concentradas em quantidades suficientes, associadas a boa permeabilidade do solo ou sistema de drenagem eficiente, promovendo assim uma lavagem natural do perfil. Todavia, sob condições de plantio em estufa a lavagem natural é impossibilitada, passando o solo a se comportar de forma semelhante aos de regiões semi-áridas (Medeiros, 1998). 


\subsection{Efeito da salinidade sobre as culturas}

Em condições salinas, ocorre uma redução na disponibilidade de água, ou seja, com o acúmulo de sais no solo o potencial total da água do solo irá sofrer uma redução, ocasionado pela contribuição do potencial osmótico. Como a água tende a deslocar-se do ponto de maior para menor potencial, haverá um maior gasto de energia para a absorção de água, apesar do potencial osmótico não ser similar ao mátrico, já que as plantas adaptam-se diferentemente às condições de salinidade (Lima, 1997). Embora algumas plantas possuam mecanismos de ajuste osmótico e consigam sobreviver, o fato da planta entrar mais rapidamente em condições de estresse, provoca o fechamento dos estômatos reduzindo a fotossíntese e diminuindo assim a translocação de nutrientes da raiz para parte aérea, além de promover um gasto de energia para absorção de íons na forma ativa.

A elevada concentração eletrolítica da solução do solo pode ainda causar desequilíbrio nutricional, toxidade de alguns íons e interferência no equilíbrio hormonal, capazes de diminuir a plasticidade da célula e causar redução da permeabilidade da membrana citoplasmática, além de influenciar no processo da fotossíntese, já que o conteúdo de clorofila nas plantas é diminuído (Larcher, 1995). Conforme Cruciani (1987), sob condições de estresse salino, as folhas podem apresentar uma coloração verde azulada escura, maior espessura e cerosidade, enquanto as raízes mostram uma diminuição do alongamento e suberização, o que reduz a absorção de água e nutrientes.

Cada espécie apresenta determinado nível de tolerância à salinidade, a partir do qual o rendimento começa a decrescer; este ponto de transição é denominado de salinidade limiar. Ayers \& Westcot (1985) citam a cultura do pimentão como moderadamente sensível. Um modelo foi proposto por Maas \& Hoffman (1977) com a finalidade de avaliar a tolerância das culturas à salinidade, onde se obtem um patamar com produtividade de $100 \%$ até a salinidade limiar. A partir deste valor ocorre um decréscimo linear da produtividade com o aumento da salinidade do solo. Analisando diversos cultivos, para diferentes climas e variedades, Maas \& Hoffman (1977) citam que para a cultura do pimentão a salinidade limiar é igual a $1,5 \mathrm{dS} \mathrm{m}^{-1}$ e o decréscimo no 
rendimento relativo para cada unidade de incremento na condutividade elétrica no extrato de saturação que excede à limiar é igual a 14 \%. Medeiros (1998) encontrou para cultura do pimentão, híbrido "Luiz", cultivado em Piracicaba sob ambiente protegido, uma salinidade limiar igual a $1,55 \mathrm{dS} \mathrm{m}^{-1}$ e uma perda relativa no rendimento de $11,4 \%$, acima do limiar. Entretanto um parecer mais criterioso a respeito da tolerância de uma determinada cultura deve levar em consideração fatores locais, tais como, tipo de solo, clima e práticas de manejo da irrigação (Tanji, 1990).

A utilização de águas de qualidades inferiores (alta salinidade) para irrigação em estufas, somada a falta de um manejo apropriado de lixiviação de sais poderá propiciar alta concentração de íons específicos na solução do solo, como o sódio, proporcionando a adsorção destes no complexo sortivo e promovendo assim uma dispersão das argilas, pela ação na expansão da dupla camada difusa, tendo como conseqüência a redução na permeabilidade do solo, com conseqüente decréscimo na taxa de infiltração, além de prejudicar o desenvolvimento radicular das plantas cultivadas.

Determinados íons são prejudiciais certas espécies de plantas, dependendo da concentração que atinjam na solução do solo em decorrência da qualidade da água de irrigação utilizada. Dentre estes íons, destacam-se o cloreto, o sódio e o boro (Ayers \& Westcot, 1985; Rhoades \& Loveday, 1990).

O nível de dano que estes íons causam às plantas depende da absorção e da tolerância da cultura e mesmo em concentrações relativamente baixas estes íons podem causar injúrias às plantas de espécies sensíveis a salinidade, sendo estas inicialmente caracterizadas pela necrose marginal do limbo foliar e clorose internerval, reduzindo a produtividade proporcionalmente ao aumento no acúmulo destes íons nas folhas. As culturas anuais mais tolerantes não sofrem injúrias a baixas concentrações, porém quase todas apresentam sintomas de toxidez ou morrem quando a concentração é elevada (Ayers \& Westcot, 1985).

A toxidez mais comum é a toxidez por cloretos advindos da água de irrigação. Como esse íon praticamente não é adsorvido pelos colóides do solo, a quase totalidade do cloreto presente na solução do solo apresenta-se altamente disponível para as plantas. Após ser absorvido pelas raízes, o cloreto é translocado para as folhas onde se 
acumula em decorrência do processo de transpiração. Em culturas sensíveis como o citrus, concentrações acima de $0,3 \%$ de cloreto na matéria seca da folha podem provocar sintomas de toxicidade, enquanto que culturas mais tolerantes como a batata podem acumular até 4 a 5\% de cloreto sem apresentar sintomas de toxicidade (Ayers \& Westcot, 1985). De acordo com Maas \& Grattan (1999) o valor limiar para a cultura do pimentão é de $15 \mathrm{~mol} \mathrm{~m}^{-3}$ de cloreto no extrato de saturação, com decréscimos na produção de $1,4 \%$ para cada incremento de $1 \mathrm{~mol} \mathrm{~m}^{-3}$ acima do limiar.

A toxidez por sódio não é tão facilmente diagnosticada como a toxidez por cloreto. Entretanto, segundo Ayers \& Westcot (1985), têm sido registrados muitos casos de toxidez por sódio devido à utilização de água com alta concentração deste íon na irrigação (alta RAS). Ao contrário dos sintomas de toxicidade do cloreto, que tem início no ápice das folhas, os sintomas de toxidez por sódio aparecem na forma de queimaduras ou necroses ao longo das bordas da folha. Estes sintomas aparecem primeiro nas folhas mais velhas e em suas bordas e, à medida que o problema se intensifica, a necrose espalha-se progressivamente pela área internerval até o centro do limbo foliar.

Os sintomas de toxidez por boro normalmente iniciam-se na forma de clorose, manchas ou secamento das pontas e bordas das folhas velhas, que caminham em direção do centro da folha pelos espaços entre as nervuras. Em alguns casos pode ocorrer exudação de goma do caule e ramos, como na amendoeira e em outras lenhosas que não exibem os sintomas típicos (Tanji, 1990).

Na maioria das culturas, os sintomas aparecem quando a concentração de boro na folha excede $250-300 \mathrm{mg} \mathrm{kg}^{-1}$ de matéria seca. Porém, algumas culturas como a macieira, pereira, pessegueiro e outras, não acumulam grande quantidade de boro nas folhas e, portanto, a toxidez por boro deve ser avaliada a partir da análise do solo e água e pelos sintomas na planta. Maas (1990) cita o pimentão como uma cultura moderadamente sensível, com concentração limiar de 1 até $2 \mathrm{~g} \mathrm{~m}^{-3}$ na solução do solo. 


\subsection{0 cultivo sob ambiente protegido: vantagens e a salinização dos solos}

O cultivo em estufas pode ser uma ferramenta efetiva para o aumento da produtividade, pois promove uma proteção contra chuvas indesejáveis, granizos e geadas, além de reduzir o ataque de pragas e consumo de água de irrigação por unidade produzida, chegando a uma economia de 50\% (Stanghellini, 1993).

Nos últimos anos observou-se um aumento no cultivo em estufas, notadamente nos países mediterrâneos (Gálvez et al., 1993). No Brasil, pode-se verificar tal ocorrência nas regiões Sudeste e Sul. Entretanto, devido ao manejo inadequado do potencial osmótico da solução do solo, os rendimentos da maioria das hortaliças e flores cultivadas vêm sendo diminuídos quando se faz plantios sucessivos nos mesmos locais.

O processo de salinização dos solos sob condições de ambiente protegido está relacionado diretamente ao acúmulo de sais em excesso na solução do solo. Existem duas causas que proporcionam o acúmulo de sais nos solos com maior freqüência no cultivo comercial sob estufas. A primeira se deve a utilização de águas de qualidade inferior provindas de poços, com alto teor de cloretos, carbonatos e bicarbonatos de sódio, cálcio e magnésio e a segunda em virtude da adição de fertilizantes de elevados índices salinos em quantidades superiores à requerida para a nutrição das plantas, sendo esta última mais freqüentemente encontrada.

Caso a salinização seja conseqüência da utilização de águas de qualidade inferior, a principal prática de controle consiste em permitir que lâminas excedentes de irrigação percolem no perfil do solo e garantam um equilíbrio favorável dos sais na zona radicular da cultura. Essa lâmina de lixiviação pode ser aplicada intencionalmente ou pode ocorrer como conseqüência das perdas espontâneas proporcionadas pela irrigação. A lâmina total a ser aplicada pode ser calculada com base na evapotranspiração, na condutividade elétrica da água de irrigação e na tolerância da cultura a salinidade. A razão entre a lâmina percolada além da zona radicular e a lâmina total aplicada é denominada na literatura de fração de lixiviação. Entretanto, para que esta prática de controle seja eficiente é necessário que a drenagem do solo seja adequada, garantindo, 
além da aeração, que o fluxo descendente prevaleça sobre o ascendente no perfil do solo e que os sais lixiviados sejam eliminados mediante drenagem (Shalhevet, 1994).

Estudos realizados pelo Departamento de Águas e Energia Elétrica do Estado de São Paulo (D.A.E.E.), têm demonstrado que a qualidade da água subterrânea algumas vezes pode ser inadequada para fins de irrigação. Na região de Piracicaba, por exemplo, segundo Oliveira \& Salati (1981) é comum a ocorrência de poços com águas ricas em cloretos e sulfatos de sódio, com teores de sais que podem propiciar uma condutividade elétrica (CE) que algumas vezes ultrapassa a 3,0 dS m $\mathrm{m}^{-1}$ e com uma razão de adsorção de sódio capaz de promover a sodificação dos solos.

A irrigação praticada em estufas, entretanto, faz uso principalmente de águas superficiais captadas em rios e em córregos, águas estas que possuem baixos teores de sais. Assim sendo, parece ser a adubação excessiva a principal causa do problema de salinização. Neste caso a remoção do excesso de sais por meio da aplicação de uma fração de lixiviação não seria a técnica mais indicada, visto que, esses fertilizantes foram adquiridos com custo financeiro, além de que atingindo o lençol freático estes sais promoverão eutrofização das águas e podem possibilitar em condições favoráveis aumento no desenvolvimento de algas e microorganismos (Silva et al., 1999).

Preocupado em garantir altas produtividades, principalmente no cultivo de hortaliças, e qualidade elevada no caso de flores, os agricultores muitas vezes aplicam quantidades elevadas de material orgânico que por si só seriam suficientes para fornecer os nutrientes exigido pelas plantas. Assim, tendo em vista que o agricultor possui a prerrogativa de aplicar adubos com parcimônia, o controle da salinização em estufas parece poder ser garantido por meio do monitoramento da concentração de sais da solução do solo, como sugerido por Burgeño (1996). Esta metodologia permite ainda conhecer a concentração de íons específicos (nutrientes) na solução do solo, evitando assim uma possível deficiência ou excesso o que poderia causar toxidez, antagonismo e ou inibição a alguns nutrientes. 


\subsection{Métodos de determinação da salinidade do solo}

Dentre os métodos empregados para estimar a concentração de sais no solo, a medida dos valores da condutividade elétrica de soluções do solo é o método mais prático. A condutividade elétrica de uma solução representa a facilidade que esta tem em transportar corrente elétrica, ou seja, mede a resistência à passagem dos elétrons, que é função da quantidade de solutos iônicos presentes na solução. Geralmente, a concentração de sais dissolvidos na solução do solo expressa em termos da condutividade elétrica a $25^{\circ} \mathrm{C}$ envolve um processo bastante simples e rápido e tem uma precisão em torno de $90 \%$ para estimar o teor de sais na solução do solo (Doneen, 1975). A CE normalmente é expressa em dS m $\mathrm{m}^{-1}$ ou mmho $\mathrm{cm}^{-1}$ a $25^{\circ} \mathrm{C}$. Além desta, outras unidades podem ser utilizadas para expressar a concentração de sais na água, como meq $\mathrm{L}^{-1}$, mmol L $\mathrm{L}^{-1}$, ppm ou mg L $\mathrm{L}^{-1}$ e $\mathrm{L}^{-1}$.

A determinação da condutividade elétrica pode ser feita em soluções de solo a diversos níveis de umidade, todavia a quantificação da condutividade elétrica do extrato de saturação (CEes) é mais evidenciada na literatura e portanto tida como método padrão, ou seja, a solução extraída de uma pasta saturada por vácuo utilizando funis de Buckner acoplados a kitassatos. As classificações de solos salinizados fixam valores limites em termos de condutividade elétrica do extrato de saturação. Dentre estas classificações destacam-se a classificação do Laboratório de Salinidade dos Estados Unidos, a qual estabelece o valor de $4 \mathrm{dS} \mathrm{m}^{-1}$ como limite entre solo salino e não salino (Richards, 1954) e a do Comitê de Terminologia da Sociedade Americana de Ciência do Solo, que fixa o valor limite em $2 \mathrm{dS} \mathrm{m}^{-1}$ (Bohn et al., 1985). Todavia, a determinação da CEes exige um bom treinamento técnico, além de certas precauções em relação à textura do solo (Queiroz et al., 1997). Rhoades (1994) afirma que podem ser cometidos erros quanto à identificação do ponto em que o solo já se encontra ou não saturado. Outra desvantagem deste método refere-se ao fato do mesmo configurar-se como trabalhoso e lento, devido à exigência de um repouso de 12 horas. Acrescenta-se ainda a necessidade encontrada em alguns solos argilosos e ou sódicos de tempo de extração superior a 24 horas. 
Geralmente o método de determinação da condutividade elétrica no extrato saturado tem se revelado excessivamente trabalhoso para um controle rotineiro em nível de propriedade rural. Experiências bem sucedidas vêm sendo realizadas com os métodos do extrato $1: 1 ; 1: 2,5$ ou 1:5 (Pereira et al. 1981), mas, em algumas condições o excesso de diluição poderá promover a solubilização de certos sais de baixa solubilidade (Richards, 1954).

Uma das alternativas seria a determinação da salinidade na solução do solo em sua umidade natural, obtida por meio de extratores, visto que, essa é a própria condição explorada pela planta e a diluição de sais nessa solução seria aproximadamente a absorvida pelas raízes (Burgueño, 1996). Outra forma de determinar a salinidade do solo em condições de campo seria pelo uso de equipamentos de instalação direta no solo e eletromagnéticos, como o probe e o portátil EM-38 sugeridos por Rhoades et al. (1999). Entretanto, esses são de custo elevado para aquisição por parte de produtores, em comparação aos extratores de solução.

\subsection{Metodologias para extração da solução do solo e o monitoramento de sua concentração iônica}

Desde o início do século XX, diversos pesquisadores procuram aperfeiçoar aparatos para extração da solução do solo, de forma que a solução apresentese o mais próximo da realidade em termos de concentração iônica. Dentre eles citam-se os trabalhos de Lipman (1918) que propunha a extração da solução por compactação de uma amostra de solo à umidade elevada, Krugel et al. (1935) que utilizou cápsulas cerâmicas para extrair a solução do solo com a finalidade de investigar a fertilidade dessa e Richards (1941) que fez uso de uma câmara de pressão para promover a retirada da solução.

Diversas são as técnicas para retirar a solução do solo. Wolt (1994) cita vários métodos: a) deslocamento da solução em coluna pela adição ou retirada de gases ou adição de líquidos (Parker, 1921; Wolt et al., 1989 e Ross \& Bartlett, 1990) , b) centrifugação a baixa (Gillman, 1976) e alta pressão (Elkhatib et al., 1987), c) câmara de 
pressão (Richards, 1941), d) por vácuo no extrato saturado e soluções aquosas (Richards, 1954), e) métodos de adsorção molecular (Baker, 1973; Norvell \& Lidsay, 1982), e f) extratores providos de cápsulas porosas (Reeve \& Doering, 1965).

Entretanto, Silva et al. (1999) citam que a extração da solução do solo por intermédio de cápsulas porosas em umidades próximas a capacidade máxima de retenção de água é de fácil execução e que várias vantagens podem ser relacionadas ao método: a solução corresponde à umidade equivalente ao momento em que a solução do solo é absorvida pela planta e assim os solutos dissolvidos são os mesmos que a planta estaria absorvendo; a amostragem é sistemática, verdadeiramente pontual e não destrutiva; a aferição da condutividade elétrica é praticamente instantânea. A solução do solo pode ainda ser extraída em diferentes níveis de umidade do solo, até o limite de 70 $\mathrm{kPa}$, sendo estas quantificadas por meio da instalação de tensiômetros e curva de retenção de água pelo solo, com relativa precisão.

Uma vez que o monitoramento periódico tenha sido estabelecido, a concentração de fertilizantes aplicados via água de irrigação, geralmente com freqüência diária ou em intervalos de poucos dias, pode ser controlada de forma a manter a concentração da solução do solo oscilando em uma faixa de CE adequada (Burgueño, 1996). Garante-se, dessa forma, alta disponibilidade de nutrientes sem a ocorrência de problemas osmóticos. Considerando-se que a aplicação de fertilizantes esteja monitorada, não há geralmente necessidade de aplicações intencionais de frações de lixiviação de manutenção, evitando assim possíveis desperdícios com água, energia e fertilizantes.

Burgueño (1996) cita ainda que, a aplicação de fertilizantes deve ser diferenciada ao longo do ciclo da cultura, visto que, a absorção de nutrientes específicos é função da fase fenológica da cultura. É inevitável que, com o passar do tempo, ocorram certos desequilíbrios nutricionais em virtude da dificuldade de quantificar com precisão os nutrientes absorvidos pela planta e as interferências inerentes do complexo de troca catiônica do sistema solo. Tendo em vista a ocorrência de situações onde se perde o controle sobre o equilíbrio dos nutrientes no solo, quando se realiza apenas o monitoramento da condutividade elétrica da solução, pode-se estabelecer um 
acompanhamento também de alguns nutrientes na solução do solo, por meio de utilização de teste rápidos cujos equipamentos são de preços acessíveis e de fácil utilização no campo.

Silva et al. (1999) afirmam que o conhecimento da composição química da solução do solo, bem como da condutividade elétrica é importante para verificar a disponibilidade de nutrientes ao longo do ciclo de uma cultura. Entretanto, a amostragem e a realização de análise periódica de solo, com a finalidade de acompanhar as concentrações dos íons na solução, durante as fases de crescimento e desenvolvimento da cultura são inviáveis economicamente em uma atividade agrícola comercial, além de não ser uma metodologia instantânea, que possibilita tomadas de decisão imediatas.

Arenas et al. (1996), constataram que o monitoramento da concentração dos íons nitrato, potássio, cálcio, magnésio, sódio e cloreto na solução do solo pode ser realizado a partir da extração dessa solução por intermédio de cápsula cerâmica e que a predição de fósforo por esta metodologia não é aceitável.

Todavia, é bem verdade que a solução do solo tem composição bastante variável no tempo e no espaço, devido a uma série de processos dinâmicos entre as fases sólidas e líquidas do solo e absorção seletiva de nutrientes pelas raízes. Sposito (1984) enfatiza a complexidade da determinação da atividade e concentração de íons na solução do solo. Dentre os principais problemas cita-se: a) dificilmente a solução do solo pode ser considerada diluída homogeneamente, b) em virtude das variações físico-químicas das superfícies, a variação de intensidade do vácuo no processo de sucção interfere na amostragem, ou seja, pequenas sucções esvaziam poros grandes e sucções maiores esvaziam poros menores e como cada poro tem uma concentração iônica diferente, os resultados são variáveis, c) e para complicar ainda mais, existe variação iônica dentro do mesmo poro, dada a proximidade das cargas trocáveis no complexo sortivo.

A concentração iônica da solução do solo depende de procedimentos observados durante a extração. Wolt (1994) cita como fatores interferentes na amostragem o tempo da extração, a zona de influência da cápsula, a tensão aplicada e o material condutor. De acordo com Morrison \& Lowery (1990) a zona de influência de 
uma cápsula cerâmica é resultado das características físico-hídricas do solo, do volume da amostra e da taxa de vácuo aplicado.

Segundo Riga \& Charpentier (1998) o tamanho da cápsula e o tempo que a mesma é submetida ao vácuo são fatores que influenciam no equilíbrio iônico na solução do solo. Os autores constataram que quanto maior a cápsula cerâmica, maior o tempo para que a solução atinja o equilíbrio iônico.

Grover \& Lamborn (1970) citam uma possível contaminação da solução do solo por sais retidos nos poros da cápsula e sugerem uma lavagem com solução de HCl. Entretanto, Silva et al. (1999) observaram que esta contaminação não é sensível na determinação da condutividade elétrica da solução do solo quando se utilizam cápsulas novas apenas lavadas com água destilada.

\subsection{Fertirrigação: técnica e impactos}

Segundo Lopez (2001) a fertirrigação é a técnica que permite aplicar fertilizantes às culturas de forma racional, via água de irrigação. Papadopoulos (1999) enfatiza a necessidade de aumentar a produtividade agrícola em virtude do incremento populacional e cita a fertirrigação como uma prática intensiva capaz de promover esse acréscimo nos rendimentos a serem alcançados. $\mathrm{O}$ mesmo autor evidencia ainda que a explosão demográfica anda em sentido contrário à disponibilidade dos recursos naturais e de novas terras aptas a expansão da agricultura. Assim sendo, a agricultura intensiva, desde que bem manejada, surge como uma alternativa capaz de aumentar a produção sem causar danos irreversíveis ao meio ambiente.

Dentre as vantagens da fertirrigação pode-se citar: menor uso de mão-deobra e fertilizantes; aplicação de fertilizantes no momento e no local que a planta necessita tendo como conseqüência uma maior eficiência de uso dos nutrientes pela planta, visto a possibilidade de parcelar a aplicação de forma desejada, além de proporcionar uma boa uniformidade de aplicação. Em contrapartida, existem alguns aspectos limitantes como: falta de recomendações apropriadas, disponibilidade de produtos específicos e sistema de irrigação mal dimensionado, pode coibir a utilização 
dessa técnica, ou, se for praticada de forma inadequada poderá trazer consequências ao meio ambiente, entre elas, a salinização das áreas irrigadas (Sousa \& Souza, 1993).

Lopez (2000) afirma que a fertirrigação bem planejada possibilita o uso mais eficiente da água e dos nutrientes por ela carreados, proporcionando assim a redução no acúmulo de sais no solo e de desequilíbrios hídricos e nutricionais, bem como a lixiviação de nutrientes capazes de atingir o lençol freático eutrofizando os cursos d'água.

Sousa \& Souza (1992) relatam que na prática da fertirrigação são pontos imprescindíveis o conhecimento das propriedades do solo, principalmente no que diz respeito a textura, $\mathrm{pH}$, teor de cátions trocáveis e em solução, densidade, permeabilidade, condutividade elétrica e de propriedades da água como a concentração de sais e $\mathrm{pH}$. Por exemplo solos arenosos, muito permeáveis e com baixa capacidade de retenção de nutrientes, favorecem a lixiviação de nutrientes, particularmente os nitratos, que contribuem para a contaminação progressiva das águas subterrâneas (Serrano et al., 1993).

O uso de alguns fertilizantes utilizados na fertirrigação, como por exemplo ácido fosfórico e sulfatos de um modo geral, tem a capacidade de acidificar o solo, sendo este problema potencializado quando a irrigação for localizada (Vitti et al. 1994). A redução do pH do solo indisponibiliza a absorção de alguns nutrientes (Malavolta et al.,1997). Entretanto, algumas fontes com efeito alcalino, como os nitratos, tem efeito direto na volatilização da amônia (Villas Bôas et al., 1999).

$\mathrm{Na}$ fertirrigação a salinização poderá ser acelerada pelo uso de fertilizantes mais salinos, normalmente de menor custo e mais atrativos ao agricultor. $\mathrm{O}$ poder de salinização do adubo pode ser medido pelos índices de salinidade global e parcial (Villas Bôas et al., 1994). O índice global representa de forma relativa o poder de salinização dos fertilizantes, onde atribui-se o índice 100 ao nitrato de sódio e os índices dos demais fertilizantes são dados comparativamente a essa referência. $O$ índice parcial considera o índice salino por unidade de nutriente; para se obter o índice parcial basta dividir o índice global pela porcentagem de nutriente que o adubo fornece. A Tabela 1 apresenta os índices de salinidade para alguns dos fertilizantes mais utilizados. 
Tabela 1. Índices de salinidade de alguns dos fertilizantes mais utilizados

\begin{tabular}{|c|c|c|}
\hline Adubos & Índice global & Índice parcial \\
\hline \multicolumn{3}{|c|}{ Adubos nitrogenados } \\
\hline Nitrato de amônio $(35,0 \%)$ & 104,7 & 2,99 \\
\hline Sulfato de amônio $(21,2 \%)$ & 69,0 & 3,25 \\
\hline Nitrato de cálcio $(11,9 \%)$ & 52,5 & 4,41 \\
\hline Cianamida cálcica $(21,0 \%)$ & 31,0 & 1,48 \\
\hline Nitrato de sódio $(13,8 \%)$ & 73,6 & 5,34 \\
\hline Nitrato de sódio $(16,5 \%)$ & 100,0 & 6,06 \\
\hline MAP - fosfato monoamônico $(12,2 \%)$ & 29,9 & 2,45 \\
\hline DAP - fosfato diamônico $(21,2 \%)$ & 34,3 & 1,61 \\
\hline Uréia $(46,6 \%)$ & 75,4 & 1,62 \\
\hline \multicolumn{3}{|c|}{ Adubos fosfatados } \\
\hline MAP $(61,7 \%)$ & 29,9 & 0,49 \\
\hline DAP $(53,8 \%)$ & 34,3 & 0,64 \\
\hline Superfosfato simples $(16,0 \%)$ & 7,8 & 0,49 \\
\hline Superfosfato simples $(18,0 \%)$ & 7,8 & 0,43 \\
\hline Superfosfato simples $(20,0 \%)$ & 7,8 & 0,39 \\
\hline Superfosfato triplo $(45,0 \%)$ & 10,1 & 0,22 \\
\hline \multicolumn{3}{|c|}{ Adubos potássicos } \\
\hline Cloreto de potássio $(60,0 \%)$ & 116,3 & 1,94 \\
\hline Nitrato de potássio $(44,0 \%)$ & 73,6 & 11,58 \\
\hline Sulfato de potássio $(54,0 \%)$ & 46,1 & 0,85 \\
\hline Sulfato de potássio + magnésio $(21,9 \%)$ & 43,2 & 1,97 \\
\hline \multicolumn{3}{|l|}{ Outros } \\
\hline Carbonato de cálcio $(56,6 \%)$ & 4,7 & 0,083 \\
\hline Calcário dolomítico $(19,0 \%)$ & 0,8 & 0,042 \\
\hline Gesso - sulfato de cálcio $(32,6 \%)$ & 8,1 & 0,247 \\
\hline
\end{tabular}

Fonte: Lorenz \& Maynard ${ }^{1}$ citado por Villas Bôas et al. (1999)

\subsection{Aspectos nutricionais e suas relações com a salinidade}

As plantas necessitam de nutrientes minerais para o seu crescimento e desenvolvimento natural. Em condições de solos salinos ocorrem, na maioria das vezes, desordens nutricionais, que causam relações antagônicas entre nutrientes na planta, as quais podem reduzir significativamente os rendimentos das culturas (Grattan \& Grieve, 1993).

\footnotetext{
${ }^{1}$ LORENS, O.A.; MAYNARD, D.N. Knott's Handbook for vegetables growers. 3. ed. New York: John Wiley, 1988. 456p.
} 
Nutrientes em excesso podem reduzir os rendimentos das culturas e sua qualidade. Por exemplo: presença de manchas em frutas ou em folhagens podem prejudicar a comercialização dos produtos e ter como conseqüência a redução do preço final (Ayers \& Westcot, 1991).

Cada nutriente tem sua função específica no crescimento e desenvolvimento vegetal. Fernandes (1971) mostra que os nutrientes mais absorvidos pelos frutos de pimentão são o nitrogênio e o potássio. Segundo Malavolta et al. (1997), o nitrogênio tem a função de estimular a formação e o desenvolvimento das gemas vegetativas e produtivas, além de participar da absorção iônica, fotossíntese, respiração, multiplicação e diferenciação celular. Este nutriente é absorvido prioritariamente pela planta nas formas de $\mathrm{NH}_{4}{ }^{+}$e $\mathrm{NO}_{3}{ }^{-}$. O sintoma visual da deficiência do nitrogênio é um característico amarelecimento específico nas folhas velhas.

De acordo com Faquin (1994) o potássio é responsável pela ativação enzimática, tem função de osmoregulação, na fotossíntese e no transporte de carboidratos. É absorvido pela planta na forma de $\mathrm{K}^{+}$e tem como sintomas visuais de deficiência presença de queimaduras nas margens das folhas mais velhas, pecíolos mais curtos e mais rígidos, internódios mais curtos e caules mais finos.

Fernandes (1971), em condições de campo, observou que a extração de macronutrientes por um cultivo de pimentão foi de $84,3 \mathrm{~kg} \mathrm{ha}^{-1}$ de potássio, $64,8 \mathrm{~kg} \mathrm{ha}^{-1}$ de cálcio, 51,2 $\mathrm{kg} \mathrm{ha}^{-1}$ de nitrogênio, 8,4 $\mathrm{kg} \mathrm{ha}^{-1}$ de magnésio, 5,4 $\mathrm{kg} \mathrm{ha}^{-1}$ de enxofre e 4,8 $\mathrm{kg} \mathrm{ha}^{-1}$ de fósforo.

Os nutrientes estão disponíveis quando encontram-se na forma solúvel e com balanço iônico adequado na solução do solo. A capacidade de troca catiônica de um solo é inversamente proporcional ao equilíbrio da solução nutritiva (Marfà, 1987). Segundo Santos \& Muraoka (1997) as propriedades químicas e físicas dos solos salinizados restringem a disponibilidade de nutrientes para as plantas, requerendo a adoção de práticas de manejo baseadas na interação salinidade-fertilidade, para tornar viável economicamente uma exploração agrícola.

Segundo Grattan \& Grieve (1993) a disponibilidade e absorção de nutrientes por uma planta depende do $\mathrm{pH}$, da concentração e composição iônica na 
solução do solo; das relações entre íons $\left(\mathrm{Na} / \mathrm{Ca}, \mathrm{Na} / \mathrm{K}, \mathrm{Ca} / \mathrm{Mg}\right.$ e $\mathrm{Cl} / \mathrm{NO}_{3}$, principalmente), e de diversos outros fatores ambientais edáficos e não edáficos.

Em uma curva de resposta de rendimentos em função de doses nutricionais, existe um ponto a partir do qual a produção máxima é alcançada e mantida em um patamar até que seja alcançada uma concentração daquele íon na solução do solo em que a produção começa a ser reduzida. Esse intervalo, entre condições de deficiência nutricional e toxidez depende particularmente do nutriente e das condições de salinidade do solo (Grattan \& Grieve, 1993). Bernstein, et al. (1974) divergem de Mass (1990) afirmando que ocorre uma interação entre a salinidade e a fertilidade dos solos, enquanto que Mass (1990) afirma que o fator que pode interferir nos rendimentos é o fator mais limitante.

De acordo com Hagin \& Tucker (1982), a elevação do teor de $\mathrm{K}^{+}$em solo salino causa distúrbio nas plantas cultivadas. $\mathrm{O}$ excesso de $\mathrm{Cl}^{-}$em solos salinos provoca redução de ânions orgânicos, fundamentais para o crescimento máximo das culturas. Entretanto, Grieve et al. (2001) relatam que manter os níveis adequados de potássio é de suma importância, visto que, altas concentrações de sódio na solução do solo além de interferir na absorção de potássio podem causar distúrbios nas membranas das raízes alterando a seletividade do sistema radicular em absorver preferencialmente potássio em relação ao sódio.

Grattan \& Grieve (1993) afirmam que o sódio em quantidade excessiva além de reduzir a absorção de potássio e cálcio pelas plantas prejudica a distribuição interna desses elementos. Alguns estudos mostram que a adição desses elementos em solos salinos pode reduzir o efeito da salinidade. A presença de íons em excesso pode ainda causar deficiências em função de competitividade entre eles. Como exemplo, o sódio em quantidade elevada pode causar deficiências nutricionais de cálcio e/ou potássio. Já o cálcio, em quantidades elevadas, possibilita a deficiência de magnésio. 


\section{MATERIAL E MÉTODOS}

\subsection{Localização dos experimentos}

Os trabalhos experimentais foram realizados em duas etapas: a primeira etapa, denominada Experimento I, foi desenvolvida em laboratório, enquanto que, a segunda etapa, denominada Experimento II, foi desenvolvida em duas estufas agrícolas. Ambos os experimentos foram realizados em dependências do Departamento de Engenharia Rural da Escola Superior de Agricultura "Luiz de Queiroz"-USP, no

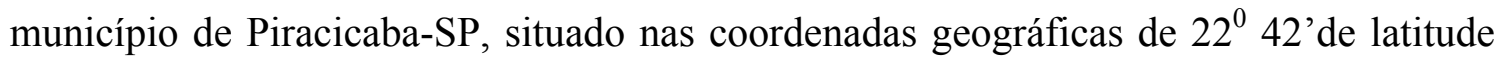
Sul e $47^{0} 38$ ' de longitude Oeste, a uma altitude de $540 \mathrm{~m}$.

A seguir estão apresentadas as metodologias adotadas em cada um dos experimentos:

\subsection{Experimento I}

A primeira etapa do experimento consistiu na realização de testes iniciais, os quais permitiram caracterizar os dois materiais de solo, um franco-arenoso e um franco-argiloso, quanto às suas propriedades físico-hídricas e químicas. Esses materiais de solo foram utilizados posteriormente no decorrer da pesquisa. Nesses testes preliminares foram, também, construídas curvas artificiais de salinização, para ambos os solos, visando conhecer o processo de salinização destes aos níveis iniciais necessários para a realização do segundo experimento. Realizou-se também testes em laboratório com a finalidade de avaliar a eficiência dos extratores na determinação da salinidade do 
solo, comparando os resultados com a metodologia padrão, ou seja, determinação da condutividade elétrica do extrato de saturação.

\subsubsection{Extração dos materiais de solo utilizados}

Foram utilizados dois materiais de solo. O primeiro material de solo foi retirado de um perfil classificado como Latossolo Vermelho Amarelo, fase arenosa, denominado Série "Sertãozinho", localizado nas coordenadas geográficas de $22^{\circ} 43$ ' 14' de latitude Sul e 47 36' 47', de longitude Oeste. O segundo, foi retirado de um perfil classificado como Terra Roxa Estruturada, fase argilosa, denominado de Série

“Luiz de Queiroz", localizado nas coordenadas geográficas de $22^{\circ} 42^{\prime} 44^{\prime}$ ' de latitude Sul e 47 $37^{\prime}$ '44', de longitude Oeste.

Ambos os materiais foram extraídos da camada de solo limitada entre a superfície e a profundidade de $30 \mathrm{~cm}$ no perfil, em locais não cultivados há pelo menos 5 anos, ou seja, em “descanso". Para extração e transporte foram utilizados uma retroescavadeira e um caminhão basculante. Após o transporte, estes solos foram passados em peneiras com malha de $2 \mathrm{~mm}$ e acondicionados em tulhas, isoladas por lonas plásticas. O volume total de materiais de solo extraído foi de $12 \mathrm{~m}^{3}$, suficiente para a realização de todo os trabalhos experimentais relativos à pesquisa.

\subsubsection{Caracterização físico-hídrica dos materiais de solo}

As propriedades físicas analisadas foram as seguintes: a)granulometria dos solos, conforme metodologia proposta por Bouyoucus (1951); b)densidade de partículas, determinada pelo método do picnômetro e c) densidade global, determinada pelo método da proveta, ambos recomendados pela EMBRAPA (1997).

As curvas características de retenção de água para ambos os materiais de solo foram construídas para tensões de até $80 \mathrm{kPa}$, utilizando-se solo acondicionado em vasos plásticos. Após a instalação de um tensiômetro para cada vaso os solos foram saturados e durante o processo de secamento foram realizadas pesagens e leituras 
tensiométricas concomitantemente. A umidade do solo em sua máxima capacidade de retenção foi determinada por pesagem após a saturação do solo e drenagem livre por 48 h, sendo o solo isolado da atmosfera por um plástico, com a finalidade de evitar a evaporação. Utilizou-se seis repetições para cada tipo de material, tanto para a construção das curvas características quanto para determinação da capacidade máxima de retenção dos materiais de solo.

\subsubsection{Caracterização química dos materiais de solo}

Os materiais de solo utilizados foram caracterizados quanto às propriedades químicas, determinando-se a concentração dos cátions, tanto na forma adsorvida quanto na solução e ânions na solução. Os cátions trocáveis foram analisados de acordo com os métodos citados pela EMBRAPA (1997). Para determinação da concentração dos íons solúveis foram confeccionadas pastas na umidade de saturação, das quais foram extraídas as soluções por intermédio de sucção, de acordo com a metodologia proposta por Richards (1949).

\subsubsection{Construção das curvas de salinização}

A obtenção das curvas artificiais de salinização teve como objetivo direcionar o processo de salinização realizado nos vasos na segunda etapa do trabalho. As mesmas foram construídas para ambos os materiais de solo utilizados, francoarenoso e franco-argiloso, acondicionando-se os mesmos em vasos de plástico e adicionando-se quantidades de sais conhecidas. Após alcançado o equilíbrio no processo iônico foi determinada a condutividade elétrica do extrato de saturação. Para constatação do período necessário ao qual ocorrera o equilíbrio iônico no processo de troca catiônica foi realizado um teste, no qual, por meio do uso de extratores de cápsula porosa, retirouse a solução do solo diariamente e determinou-se a condutividade elétrica. $\mathrm{O}$ equilíbrio foi alcançado no momento em que a condutividade elétrica da solução do solo manteve- 
se constante ao longo do tempo, ou seja, no segundo dia após a aplicação da solução salinizadora.

Simultaneamente à elevação da umidade do solo dos vasos à sua máxima capacidade de retenção foram adicionados os sais fertilizantes, diluídos na água, obtendo assim a salinização do solo com valores de condutividade elétrica do extrato de saturação almejados $\left(1,0,2,0,3,0,4,0,5,0,6,0,7,0,8,0,9,0\right.$ e $\left.10,0 \mathrm{dS} \mathrm{m}^{-1}\right)$. A proporção, bem como os tipos de sais aplicados foram os mesmos utilizados por Medeiros (1998), o qual, seguiu as recomendações referentes à cultura de pimentão, para NPK de Bar-Yosef (1991) e para Ca e Mg de Vivancos (1993). As quantidades de sais adicionados foram estimadas pela equação 1, apresentada por Richards (1954):

$$
\mathrm{QS}=\mathrm{CE}_{\mathrm{es}} \cdot 640 . \mathrm{V}_{\mathrm{s}}
$$

em que

QS = quantidade de sais aplicados, mg por vaso;

$\mathrm{V}_{\mathrm{s}}=$ volume de água presente no solo quando este estiver saturado, L por vaso;

$\mathrm{CE}_{\text {es }}=$ condutividade elétrica requerida no extrato de saturação, $\mathrm{dS} \mathrm{m}^{-1}$.

Dois dias após a adição das diversas soluções salinas foram retiradas amostras de solo dos vasos na camada de 0 a $20 \mathrm{~cm}$, após uma raspagem na qual se eliminou $2 \mathrm{~cm}$ da superfície do solo. A partir dessa amostragem determinou-se a condutividade elétrica do extrato de saturação real, ou seja, aquela que correspondeu aos valores encontrados no solo. As curvas de salinização foram construídas por meio de diagramas de dispersão, onde foram plotados os valores de condutividade encontrados versus as quantidades de sais correspondentemente aplicadas.

3.2.5 Testes iniciais dos extratores na determinação da salinidade do solo

Com a finalidade de avaliar o uso de extratores providos de cápsulas cerâmicas na determinação da condutividade elétrica da solução do solo foi conduzido um teste inicial, comparando os resultados obtidos por essa metodologia com os 
métodos mais usuais de determinação de salinidade no solo. O teste foi conduzido no Laboratório de Física do Solo do Departamento de Engenharia Rural, no qual se utilizou o primeiro material de solo (Latossolo Vermelho-Amarelo). Este material foi acondicionado em vasos de $14 \mathrm{~L}$, tendo em sua base uma camada de envelope de $2 \mathrm{~cm}$ (brita + manta sintética).

O processo de salinização do solo ocorreu durante o cultivo de dois ciclos consecutivos de alface, onde, utilizaram-se águas de irrigação com quatro concentrações de sais $\left(\mathrm{C} 1=1,0 ; \mathrm{C} 2=2,5 ; \mathrm{C} 3=4,0\right.$ e $\left.\mathrm{C} 4=5,5 \mathrm{dS} \mathrm{m}^{-1}\right)$ sobre as quais foram acrescidas, semanalmente, duas lâminas de lixiviação ( $\mathrm{L} 1=10 \%$ e L2 $=30 \%$ ), gerando assim diferentes níveis de salinidade inicial do solo.

Os tratamentos em fatorial possuíram seis repetições, totalizando 48 vasos. A concentração da água $\mathrm{C} 1$ foi obtida diluindo-se a $1 / 3$ uma solução hidropônica proposta por Furlani (1995); as demais águas continham, além da mesma quantidade de solução hidropônica, $\mathrm{NaCl}$ e $\mathrm{CaCl}_{2}$ na proporção de $\mathrm{Na}: \mathrm{Ca}$ de $1: 1$, em termos de mmol L ${ }^{-1}$, com a finalidade de elevar a condutividade elétrica aos valores especificados anteriormente. Com antecedência de um mês antes do primeiro plantio da alface, foram adicionados, aos vasos, $10 \mathrm{~g}$ de $\mathrm{CaCO}_{3}$, visando-se corrigir a acidez do solo. Após a colheita da alface no segundo ciclo, foi adicionada água destilada aos vasos, em volume suficiente para elevar a umidade destes à máxima capacidade de retenção; desta forma, corrigiu-se a heterogeneidade nos níveis de umidade, no momento da retirada da solução analisada.

A pasta saturada para determinação de CEes foi preparada utilizando-se $250 \mathrm{~g}$ de solo seco e adicionando-se água destilada até o ponto de saturação; durante este procedimento, mediu-se o volume de água destilada utilizada para calcular a umidade de saturação. As pastas foram colocadas em repouso por um período de $20 \mathrm{~h}$ e, em seguida, retirou-se por meio de sucção a $80 \mathrm{kPa}$, os extratos saturados, nos quais foi medida a condutividade elétrica.

Para o preparo da solução 1:2 (solo seco: água destilada) foram pesados $50 \mathrm{~g}$ de solo seco, proveniente dos vasos, aos quais foram adicionados $100 \mathrm{~mL}$ de água destilada e, após agitação por um período de 15 minutos, a suspensão foi colocada em 
repouso por $2 \mathrm{~h}$ e determinou-se a $\mathrm{CE}_{1: 2}$ no sobrenadante, como executado por Medeiros (1998).

A profundidades de $15 \mathrm{~cm}$ instalaram-se os extratores de solução nos vasos, providos de cápsulas porosas de cerâmica em sua extremidade inferior. Essas cápsulas já tinham sido testadas quanto a uma possível contaminação da solução por sais, visto que alguns resíduos poderiam estar presentes nos poros, proporcionando um intercâmbio catiônico como citam Grover \& Lamborn (1970). Aos extratores foi aplicado vácuo de $80 \mathrm{kPa}$ e após o seu preenchimento, coletou-se a solução. Determinou-se a umidade do solo na profundidade da cápsula porosa, pelo método gravimétrico, com a finalidade de se corrigir o efeito da umidade do solo sobre a condutividade elétrica da solução, enquanto as medidas de condutividade elétrica foram também corrigidas em função da temperatura e expressas em valores a $25^{\circ} \mathrm{C}$.

A Figura 1 ilustra a disposição dos vasos no experimento e a Figura 2 a utilização de um vacuômetro para auxiliar na extração da solução do solo por meio de cápsulas porosas. Existe a possibilidade de se utilizar bombas manuais, e seringas descartáveis, mais práticas quando da utilização no campo. 


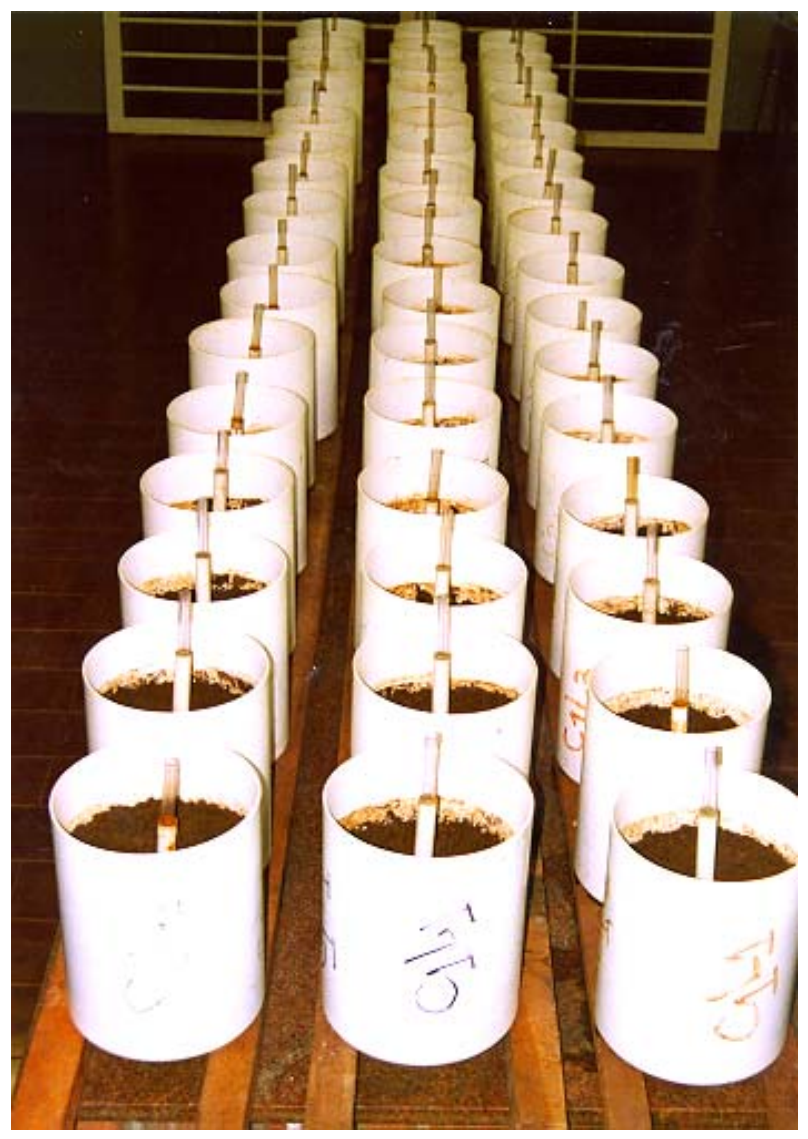

Figura 1 - Disposição dos vasos no experimento conduzido em laboratório

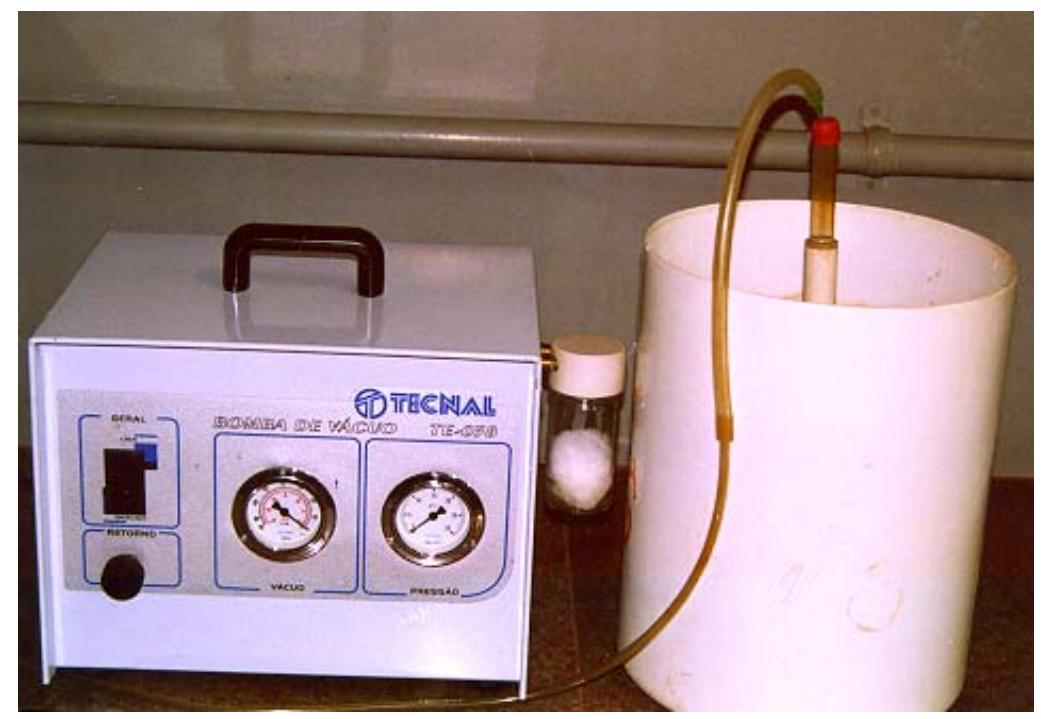

Figura 2 - Extração da solução do solo por aplicação de vácuo 
O método da solução 1:2 e o do extrator de solução foram comparados com o método-padrão da pasta saturada, por intermédio de análise de regressão. Visando-se analisar o efeito da interferência dos diversos níveis de umidade, correspondente a cada um dos métodos, sobre os valores de condutividade elétrica, foram realizadas correções em relação à umidade do método-padrão (CEes) ou seja, umidade de saturação, utilizando-se as umidades no momento de retirada da solução do solo pelo extrator de cápsula porosa e a umidade relativa ao método 1:2; para tal, foram empregadas as equações 2 e 3 respectivamente:

$$
\begin{gathered}
\text { CEes }_{\text {estimada }} \operatorname{scp}=\frac{\text { CEscp } \cdot \text { Uscp }}{U s} \\
\mathrm{CEes}_{\text {estimata }} 1: 2=\frac{\mathrm{CE}_{1: 2} \cdot \mathrm{U}_{1: 2}}{\mathrm{Us}}
\end{gathered}
$$

em que

CEes estimada $\mathrm{scp}=$ condutividade elétrica do extrato de saturação estimada a partir da condutividade elétrica da solução do solo obtida com extrator de cápsula, sendo corrigida para a umidade da pasta saturada, $\mathrm{dS} \mathrm{m}{ }^{-1}$;

CEscp $=\quad$ condutividade elétrica da solução do solo obtida com extrator de cápsula porosa, $\mathrm{dS} \mathrm{m}^{-1}$;

Uscp $=\quad$ umidade do solo no momento da retirada da solução com o extrator de cápsula porosa, $\mathrm{g} \mathrm{g}^{-1}$;

Us $=\quad$ umidade do solo na pasta saturada, $\mathrm{g} \mathrm{g}^{-1}$;

CEes estimada $1: 2=$ condutividade elétrica do extrato de saturação estimada a partir da condutividade elétrica da solução diluída 1:2, sendo corrigida para a umidade da pasta saturada, dS m ${ }^{-1}$;

$\mathrm{CE}_{1: 2}=\quad$ condutividade elétrica na solução diluída $1: 2, \mathrm{dS} \mathrm{m}^{-1}$;

$\mathrm{U}_{1: 2}=\quad$ umidade existente na solução diluída 1:2, ou seja, 2 gramas de água por 1 grama de solo, $\mathrm{g} \mathrm{g}^{-1}$. 
Apesar do ajuste relacionado à quantidade de sais e condutividade elétrica de uma solução não ser linear optou-se pela utilização desses modelos, em virtude da praticidade para uso em campo e da estreita faixa de condutividade elétrica determinada na maioria dos casos. O intervalo no qual constam os valores de condutividade elétrica encontrados proporciona a utilização de um ajuste linear com uma precisão satisfatória.

\subsection{Experimento II}

\subsubsection{Descrição da estrutura experimental}

O Experimento II foi conduzido em duas estufas de plástico com cobertura em arco, apresentando cada uma $6,40 \mathrm{~m}$ de largura e $22,5 \mathrm{~m}$ de comprimento. As paredes laterais e frontais foram confeccionadas com telas tipo clarite, possuindo um rodapé de $20 \mathrm{~cm}$ em concreto armado. As mesmas possuíam cortinas laterais, as quais permitiram reduzir a variação de temperatura em seu interior e proteger contra chuvas de vento. A cobertura consistiu de manta de polietileno de baixa densidade, transparente, com $0,10 \mathrm{~mm}$ de espessura, tratada contra a ação de raios ultravioletas. A estrutura experimental foi provida de energia elétrica e de abastecimento de água com baixo teor de sais (Figura 3A).

Foram construídas janelas frontais (Figura 3B), localizadas nos arcos, com o objetivo de reduzir a temperatura abaixo de $27^{\circ} \mathrm{C}$, visto que, foram alcançadas altas temperaturas durante o período de cultivo, o qual coincidiu com a época mais quente do ano. As janelas tiveram uma boa eficiência na redução da temperatura em virtude das mesmas localizarem-se na parte superior da estufa, área de acúmulo de calor, e por processo convectivo as massas com temperaturas elevadas apresentaram um deslocamento no sentido das janelas laterais. 


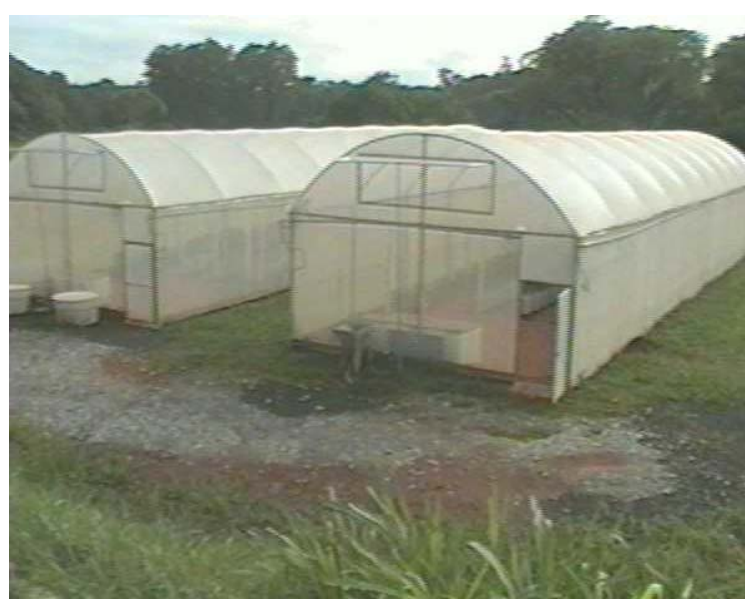

(A)

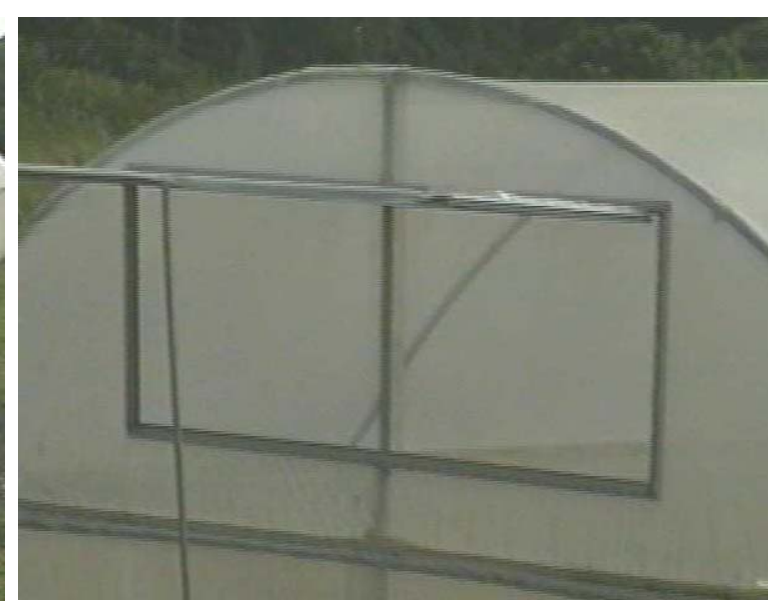

(B)

Figura 3 - A) Vista frontal das estufas agrícolas utilizadas no experimento II ; B) Detalhe das janelas frontais

\subsubsection{Tratamentos e delineamento experimental}

Os tratamentos foram compostos em um esquema fatorial completo (9x2x2) com: 9 níveis de salinidade inicial do solo $(\mathrm{N} 1=1, \mathrm{~N} 2=2, \mathrm{~N} 3=3, \mathrm{~N} 4=4, \mathrm{~N} 5=$ $5, \mathrm{~N} 6=6, \mathrm{~N} 7=7, \mathrm{~N} 8=8$ e $\left.\mathrm{N} 9=9 \mathrm{dS} \mathrm{m}{ }^{-1}\right) ; 2$ solos com diferentes texturas $(\mathrm{S} 1=$ francoarenoso e S2= franco-argiloso) e 2 manejos de fertirrigação (M1= tradicional e M2= com controle da concentração iônica da solução do solo). O delineamento estatístico adotado foi em blocos casualizados, com 4 repetições, resultando em 144 parcelas experimentais, ou seja, 144 vasos de 62 L, dispostos conforme a Figura 4. 


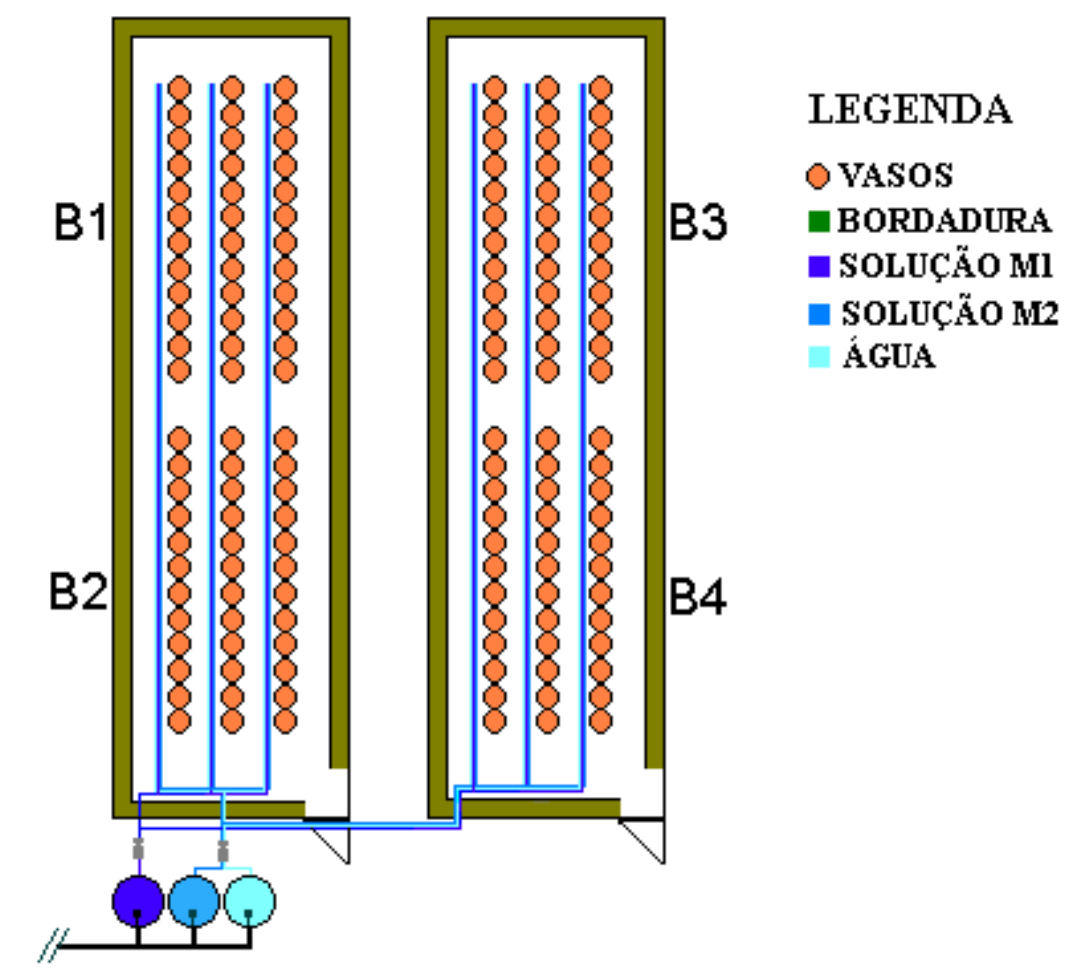

Figura 4 - Croquis da área experimental

Os diversos níveis de salinidade inicial do solo (N1, N2, N3, N4, N5, N6, N7, N8 e N9) simularam diversos estágios de salinização do solo, possivelmente encontrados quando detectado o problema por parte dos agricultores. Estes níveis possibilitaram verificar os efeitos da salinização na redução do crescimento, desenvolvimento e produção da cultura implantada. Foi possível também avaliar a eficiência do extrator de solução, associado ao manejo de fertirrigação M2, sobre o controle da salinização do solo em várias concentrações iônicas na solução do solo e avaliar o efeito de diferentes concentrações iônicas parciais sob a cultura.

A utilização de dois materiais de solo, um com textura franco-arenosa (S1) e o outro com textura franco-argilosa (S2) teve como finalidade observar a interferência de uma maior quantidade de argila nos manejos de fertirrigação utilizados, visto que, parte dos íons aplicados seriam adsorvidos no complexo de troca. Desta forma, o manejo da fertirrigação onde a concentração de íons na solução do solo foi 
monitorada teve um caráter corretivo e pôde ser convenientemente testado para dois solos de diferentes texturas.

Os diferentes manejos de fertirrigação estudados: tradicional, com manejo pré-estabelecido com base na marcha de absorção de nutrientes pela cultura (M1) e o controlado, com base na concentração de íons na solução do solo (M2), teve por objetivo avaliar o comportamento da disponibilidade e de concentrações tóxicas de nutrientes, bem como do processo de salinização do solo. Comparou-se assim, os resultados obtidos pela metodologia proposta (M2) com os obtidos na metodologia tradicional (M1).

\subsubsection{Cultura utilizada}

Utilizou-se um híbrido de pimentão (Capsicum annuum, L.), denominado comercialmente de "Elisa", procedente da Rogers. O fruto tem formato retangular e tamanho médio, apresenta alta percentagem de quatro lóculos bem definidos. Os frutos, quando maduros, apresentam coloração vermelha e espessura de polpa grossa $(7 \mathrm{~mm})$. As plantas atingem a primeira colheita por volta dos 100 dias após semeadura, e se adaptam muito bem ao cultivo protegido.

\subsubsection{Condução do trabalho}

\subsubsection{Acondicionamento e salinização dos materiais de solo}

Os diferentes materiais de solo, peneirados em malha de $2 \mathrm{~mm}$ e armazenados em tulha, foram acondicionados em vasos plásticos de $62 \mathrm{~L}$, com $42 \mathrm{~cm}$ de diâmetro e $54 \mathrm{~cm}$ de altura. Os vasos foram perfurados e providos de um sistema de drenagem em sua parte inferior, com $3 \mathrm{~cm}$ de brita $\mathrm{n}^{\mathbf{0}} 1$ e manta poliéster. $\mathrm{O}$ preenchimento foi realizado de modo semelhante à forma utilizada na determinação da densidade global pelo método da proveta.

A utilização de vasos permitiu que o experimento fosse realizado com solos diferentes em um mesmo local e em um mesmo tempo, sendo que o tamanho dos 
vasos escolhidos não ocasionou uma restrição no desenvolvimento do sistema radicular das plantas de pimentão.

A salinização do solo se deu por meio da aplicação de uma solução salina, sendo que, as quantidades de sais adicionadas foram determinadas pela curva de salinização correspondente a cada solo, gerada pelo experimento I e a quantidade de água foi a necessária para elevar a umidade do solo a capacidade de campo. Após a adição da solução foram retiradas amostras dos vasos para aferir a condutividade elétrica do extrato de saturação. Comparou-se a salinidade determinada com a desejada e quando necessário foi adicionada uma nova solução salina de ajuste, baseada no mesmo princípio citado anteriormente.

\subsubsection{Transplantio e condução das plantas}

O transplantio foi realizado no dia 11/10/2000, 45 dias após a semeadura, colocando-se uma muda por vaso, sendo essas uniformes com $15 \mathrm{~cm}$ de altura e 4 pares de folhas. Estas mudas foram adquiridas de um viveirista especializado, conforme recomendado por Tivelli (1998). As mudas apresentaram um pegamento de 100\%, sendo que apenas uma planta teve de ser replantada, em virtude de um ataque individual de formigas cortadeiras. Até 10 dias após o transplante a irrigação foi suficiente apenas para promover o pegamento, não sendo realizado eventos de fertirrigação. Os vasos foram posicionados de forma que as plantas ficaram espaçadas de $0,5 \mathrm{~m}$ entre plantas e $1,2 \mathrm{~m}$ entre linhas. Foi implantada uma linha de plantio junto à tela das estufas, a qual funcionou como bordadura (Figura 5). 


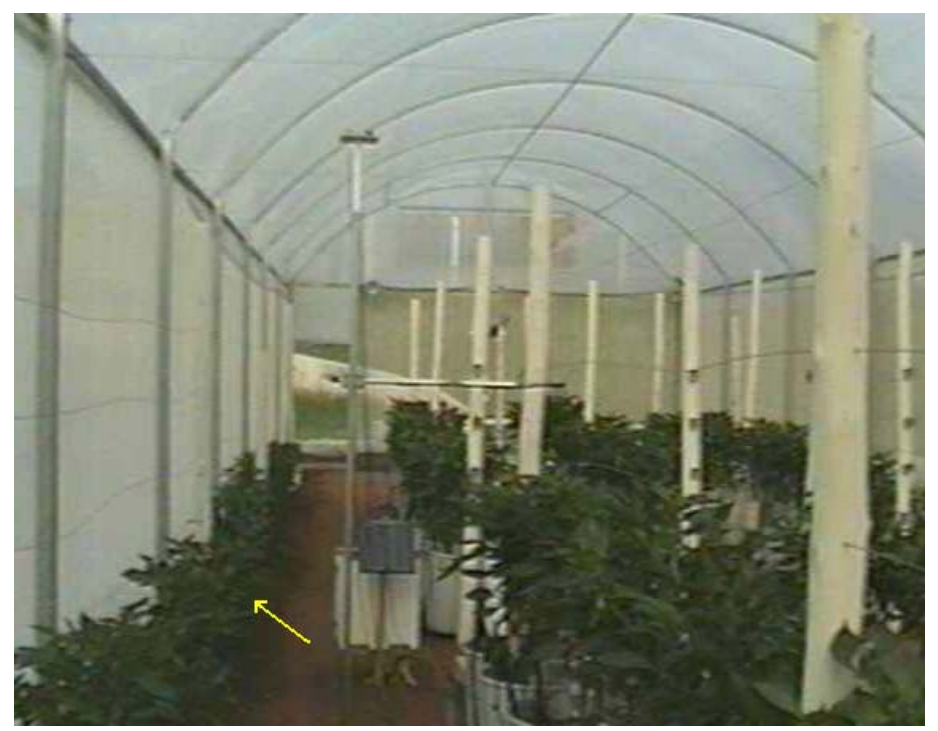

Figura 5 - Linha lateral de plantio para efeito de bordadura

O tutoramento foi em espaldeira simples, com as hastes conduzidas de maneira tal a formar um renque. Cada haste foi amarrada em arames dispostos horizontalmente e espaçados de $30 \mathrm{~cm}$ um dos outros. A desbrota foi realizada de maneira a eliminar os brotos laterais que se formam abaixo da primeira bifurcação e aqueles formados internamente. A primeira flor que surgiu na bifurcação foi eliminada.

\subsubsection{Manejo da irrigação}

Foi adotado um sistema de irrigação por gotejamento, utilizando um emissor com vazão de $2 \mathrm{~L} \mathrm{~h}^{-1}$ por planta, sendo que os vasos dos tratamentos M2 possuíram dois gotejadores, um para aplicar solução de fertirrigação e outro para aplicar só água, quando a aplicação de fertilizantes não era necessária, evitando assim uma possível contaminação. O sistema instalado em campo possuía um coeficiente de uniformidade de Christiansen (CUC) igual à 93,2\%.

Junto a cada fileira de vasos passaram três linhas de PVC, a primeira com solução aplicada nos tratamentos com manejo M1, a segunda com solução para os tratamentos com manejo M2 e a terceira com água, utilizada no caso de não ser necessário fertirrigar os tratamentos com manejo M2. Os gotejadores foram acoplados 
nas linhas de tubos de PVC correspondentes por meio de microtubos de polietileno. Nestes microtubos foram instalados microregistros, com os quais foi possível aplicar o volume de água diferenciadamente.

O manejo de irrigação foi baseado em dados de umidade do solo, obtidos pela utilização de tensiômetros instalados a $20 \mathrm{~cm}$ de profundidade e de curvas características de retenção de água no solo, construídas durante o experimento I. O momento do evento de irrigação foi dado quando a média das leituras tensiométricas de todos os vasos atingia $30 \mathrm{kPa}$ e a quantidade de água aplicada foi a suficiente para elevar a umidade à capacidade de campo.

O volume de água aplicado foi calculado a partir da curva característica de retenção da água no solo e das médias das leituras tensiométricas para cada nível de salinidade e tipo de solo, separadamente.

\subsubsection{Adubação}

A aplicação dos fertilizantes foi realizada via água de irrigação, sendo o manejo diferenciado para os tratamentos M1 e M2. Para o tratamento M1 foram utilizadas as recomendações propostas por Bar-Yosef (1991) para NPK e Vivancos (1993) para Ca e Mg, correspondendo a $270 \mathrm{~kg} \mathrm{ha}^{-1}$ de N, $50 \mathrm{~kg} \mathrm{ha}^{-1}$ de $\mathrm{P}_{2} \mathrm{O}_{5}, 580 \mathrm{~kg} \mathrm{ha}^{-1}$ de $\mathrm{K}_{2} \mathrm{O}$ e $13 \mathrm{~kg} \mathrm{ha}^{-1}$ de $\mathrm{MgO}$, respectivamente, sendo observada a marcha de absorção da cultura. Por meio da estimativa de consumo da água ao longo do ciclo foi feita uma programação da aplicação dos fertilizantes. A freqüência da fertirrigação para este tratamento seguiu a mesma freqüência da irrigação.

Para o tratamento referente ao manejo M2, inicialmente, foi utilizada a mesma recomendação do manejo M1. Entretanto, posteriormente neste manejo não foi pré-estabelecida a freqüência nem a proporção dos fertilizantes aplicados. A fertirrigação só foi realizada quando a condutividade elétrica na solução do solo estava em média $20 \%$ abaixo dos níveis iniciais de salinização do solo para cada tratamento e esta foi cessada quando a condutividade atingia, em média, 20\% acima dos mesmos níveis iniciais. A concentração iônica parcial na solução do solo foi corrigida da mesma 
forma e na mesma magnitude, $20 \%$ acima e abaixo, para todos os macronutrientes, tendo-se como base a média percentual de cada um dos tratamentos. Desta forma a concentração iônica total e de íons específicos na solução do solo foi que controlou o manejo da fertirrigação. Quando não era necessário aplicar fertilizantes o evento de irrigação foi realizado só com água.

Os fertilizantes aplicados foram previamente dissolvidos em soluções estoque, ou seja, em concentrações elevadas. De acordo com o programado para o tratamento M1 ou conforme o necessário para o tratamento M2, volumes destas soluções foram diluídas nas águas de irrigação, contidas em caixas de amianto correspondentes para cada tratamento.

Utilizou-se como fertilizantes os seguintes produtos: nitrato de cálcio, cloreto de potássio, sulfato de amônio, sulfato de magnésio e ácido fosfórico.

\subsubsection{Extração da solução do solo}

A solução do solo foi obtida utilizando-se extratores providos de cápsulas cerâmicas em sua extremidade inferior e borrachas especiais com vedação de silicone na extremidade superior. Foi promovida uma tensão de aproximadamente $80 \mathrm{kPa}$ por meio de uma bomba de vácuo. As cápsulas foram localizadas a uma profundidade de $20 \mathrm{~cm}$ da superfície do solo. A aplicação do vácuo aos extratores se deu $12 \mathrm{~h}$ após a irrigação. Neste momento foi verificada a umidade do solo, por meio de tensiometria. Os extratores foram instalados opostamente aos tensiômetros, a uma distância de $10 \mathrm{~cm}$ da planta.

Ao início e término do ciclo da cultura foram retiradas amostras de solo para a preparação da pasta de saturação, adicionando-se água destilada aos poucos, sempre medindo o volume para o posterior cálculo da umidade de saturação, sendo descontados, posteriormente, também a umidade residual, visto que o solo utilizado foi seco ao ar. As pastas foram colocadas em repouso por um período de $20 \mathrm{~h}$ e em seguida foram retirados os extratos de saturação por meio de sucção, conforme metodologia proposta por Richards (1954). 
Os valores de condutividade elétrica e concentração de íons macronutrientes medidos na solução retirada a partir dos extratores de cápsula porosa a diferentes umidades do solo foram comparados com os valores obtidos pelo método padrão, ou seja, pela medição da condutividade elétrica e concentração de íons macronutrientes no extrato da pasta saturada. Para tal foi realizada uma análise de regressão, sendo corrigidos os valores de leitura de condutividade elétrica da solução em função da umidade de saturação por intermédio da equação 2 .

\subsubsection{Variáveis agroclimáticas e demanda hídrica}

Por intermédio de sensores apropriados e sistema de aquisição eletrônica de dados (Datalogger - CR10) foram medidos a cada segundo com média de 30 minutos, as seguintes variáveis climáticas: a) temperatura e umidade relativa do ar; b) radiação global, líquida e fotossiteticamente ativa e c) evaporação. Com base nesses dados foi possível estimar a evapotranspiração pelos modelos matemáticos sugeridos por PenmanMontheith (ETPM) e pelo método da radiação (ETRad), citados por Pereira et al. (1997) e compará-los aos valores de consumo determinados pelo balanço hídrico. Os equipamentos utilizados podem ser visualizados na Figura 6.

Como o consumo de água pelas culturas é influenciado também pelo incremento da salinidade do solo, determinou-se a redução na evapotranspiração e quantificaram-se os coeficientes que levam em consideração a acúmulo de sais no solo. Esses coeficientes foram denominados de coeficiente de cultura $(\mathrm{Kc})$ para o tratamento não salino e de coeficiente de salinidade (Ks) para os demais. A evapotranspiração de referência por evaporação (ETL) foi estimada com base em leituras diárias da evaporação em mini-tanque ( $0,6 \mathrm{~m}$ de diâm e $0,3 \mathrm{~m}$ de profundidade) e coeficiente de tanque (Kp) igual a 1, conforme recomendação de Medeiros et al. (1997).

A evapotranspiração da cultura (ETc) foi determinada a partir do balanço hídrico. Para determinação do Kc do pimentão, foi dividido o ciclo fenológico em quatros fases, de acordo com Doorenbos \& Pruitt (1977): A primeira fase compreendeu a fase inicial com duração de 30 dias; a segunda fase compreendeu a fase de crescimento 
com duração de 40 dias; a terceira fase compreendeu a fase intermediária com duração de 60 dias e a fase final com duração de 20 dias.

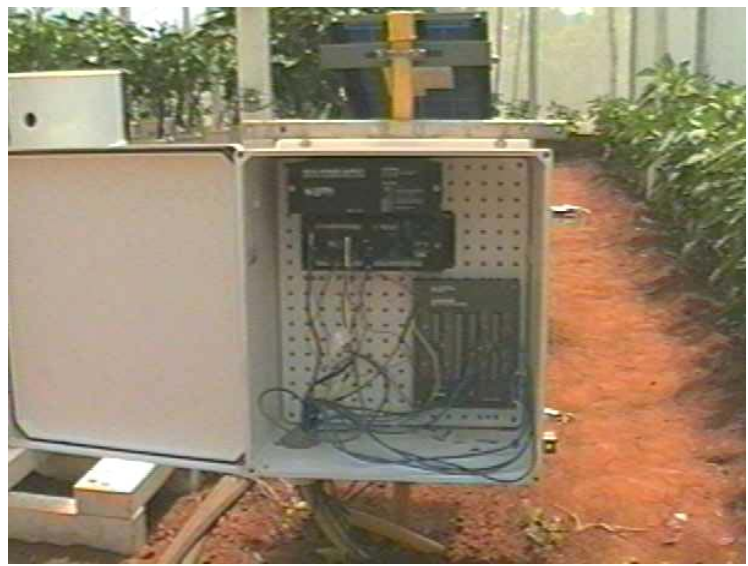

(A)

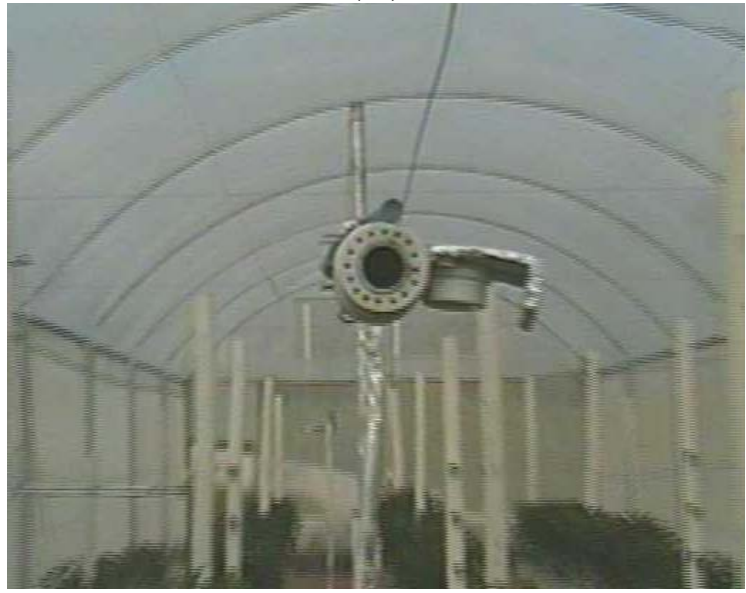

(C)

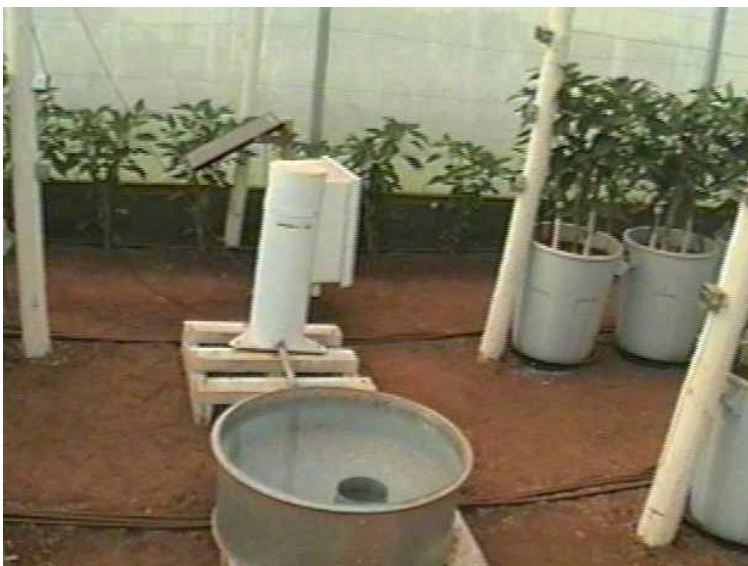

(B)

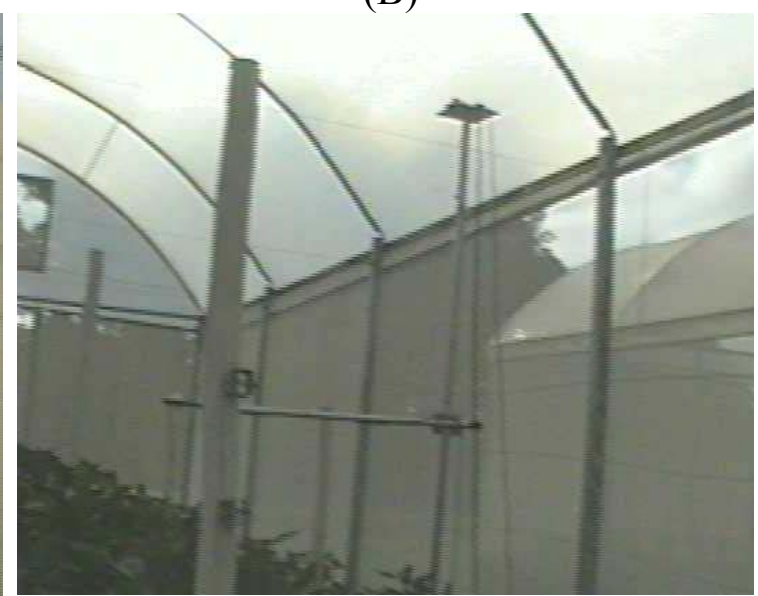

(D)

Figura 6 - Equipamentos para aquisição de dados agroclimáticos: A) Datalogger (CR10); B) Mini tanque evaporimétrico automatizado; C) Psicrômetro com ventilação forçada; D) Radiômetros de radiação líquida, global e fotossinteticamente ativa

O Kc foi calculado com base na razão entre ETc e ETL. Em função dos níveis crescentes de salinidade do solo, determinou-se a evapotranspiração real (ETr), visto que o incremento no acúmulo de sais representa um decréscimo na evapotranspiração da cultura. Esse decréscimo foi quantificado por um coeficiente de salinidade (Ks), representado matematicamente pela equação 4: 


$$
\mathrm{Ks}=\frac{\mathrm{ETr}}{\mathrm{ETL} \cdot \mathrm{Kc}}
$$

Os dados de $\mathrm{Kc}$ calculados foram comparados com os valores encontrados por Medeiros (1998) e Doorenbos \& Kassam (1979) para cada fase fenológica da cultura estudada.

\subsubsection{Variáveis relacionadas à cultura}

\subsubsection{Altura das plantas}

As medições foram realizadas semanalmente em todas as plantas até o final do ciclo da cultura, com o auxílio de uma trena graduada em centímetros e tomando como referencia superior o ápice do ramo mais alto e como referência inferior a superfície do solo.

\subsubsection{Diâmetro de colo}

Foram realizadas medições quinzenais do diâmetro do colo de todas as plantas do início ao final do ciclo da cultura, tendo como referência $1 \mathrm{~cm}$ de altura em relação à superfície do solo, com o auxílio de um paquímetro digital e escala de leitura em milímetros.

\subsubsection{Rendimento e componentes de produção}

Após o início do período produtivo, com a primeira colheita realizada no dia $05 / 12 / 2000$, foram feitas colheitas semanais determinando-se o número de frutos por planta, produção, dimensões dos frutos (largura e comprimento) e peso médio dos frutos em todas as colheitas. Determinou-se a espessura de casca para todos os frutos durante a 
primeira e última colheita. $\mathrm{O}$ diâmetro foi determinado na terça parte superior do fruto e nesse local foi feita uma inserção afim de possibilitar a medida da espessura de casca.

\subsubsection{Massa seca dos frutos}

Foi realizada por ocasião da primeira e última colheita, utilizando-se um fruto comercial por planta. Os frutos foram secados em estufa ventilada e com temperatura de $65^{\circ} \mathrm{C}$, até atingirem peso constante. Foram realizadas análises por regressões matemáticas com a finalidade de estabelecer a relação entre matéria seca e verde nos frutos.

\subsubsection{Massa verde e seca da parte aérea das plantas}

No final do ciclo produtivo foram determinadas separadamente para as folhas e caule a massa verde e seca da parte aérea das plantas. Ao final do ciclo retirouse todas as plantas e imediatamente as mesmas foram colocadas em sacos plásticos, com

a finalidade de evitar perdas por transpiração; em seguida determinou-se a biomassa verde total de cada planta descontando-se a tara. Os sacos plásticos foram abertos e retirou-se as folhas, determinado-se a biomassa verde do caule. A biomassa verde das folhas foi determinada pela diferença entre as variáveis biomassa total e biomassa do caule. As partes foram colocadas em estufa ventilada, a uma temperatura de $65^{\circ} \mathrm{C}$ e após alcançado o equilíbrio determinou-se a massa seca do caule e folhas. Por regressão linear simples estimou-se a proporção de massa seca em relação a verde.

\subsubsection{Níveis de nitrato e potássio na seiva da planta}

As concentrações de nitrato e potássio na seiva foram determinadas em intervalos de 21 dias a partir do transplantio, por meio de teste rápido de campo, utilizando medidores de íon compacto marca Horiba (Figura 7). As medidas foram realizadas na seiva extraída do pecíolo de uma folha expandida, retirada sempre dos 
ramos intermediários, sendo uma folha por planta. A extração da seiva no pecíolo foi realizada com o auxílio de uma prensa manual.

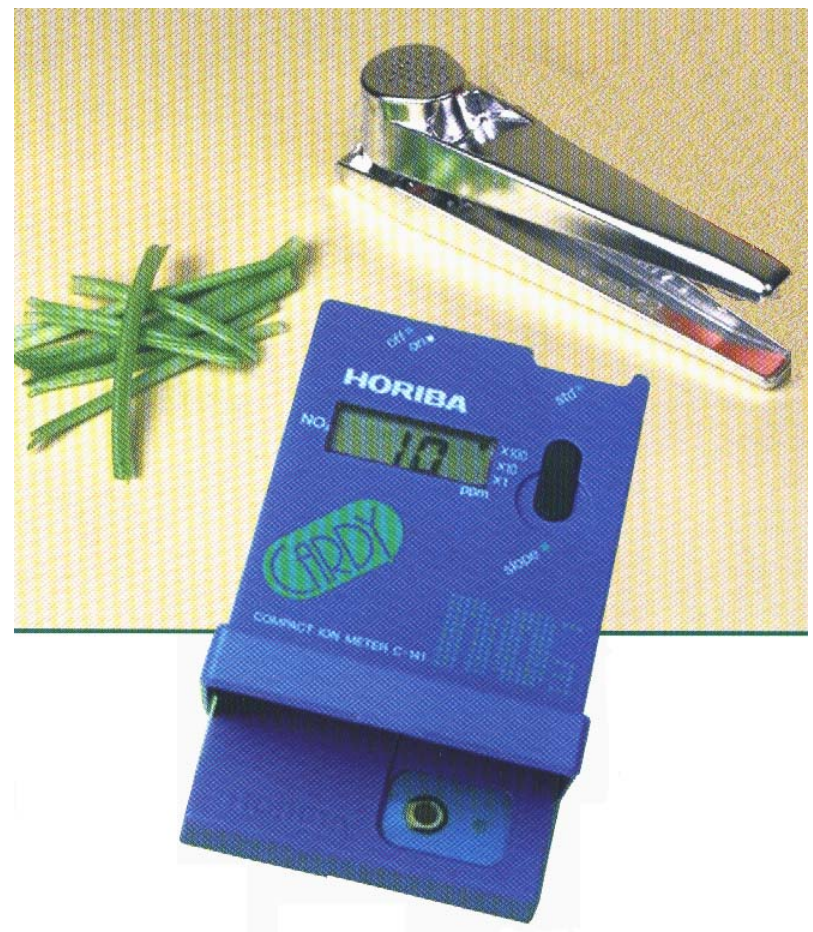

Figura 7 - Equipamentos para determinação da concentração iônica na seiva da planta

\subsubsection{Teores de macronutrientes, sólidos solúveis totais e acidez nos frutos}

As determinações de macronutrientes, sólidos solúveis totais e acidez nos frutos foram realizadas em amostras compostas de um fruto comercial de cada bloco, para cada tratamento, por ocasião da última colheita. Os macronutrientes nos frutos foram determinados em laboratório segundo a metodologia sugerida por Malavolta et al. (1997). Os sólidos solúveis totais foram medidos por meio de um refratômetro digital, após filtragem do homogenato em gaze, e os resultados foram expressos em ${ }^{\circ}$ Brix, segundo AOAC (1990). A acidez total titulável foi determinada com $\mathrm{NaOH} 0,1 \mathrm{~N}$, de acordo com o Instituto Adofo Lutz (1985), e os resultados foram expressos em \% de ácido cítrico. 


\subsubsection{Ajustamento osmótico das plantas}

O ajustamento osmótico das plantas aos diversos níveis de salinidade do solo foi determinado durante as fases fenológicas de crescimento e desenvolvimento da cultura, de acordo com a metodologia das curvas de pressão-volume, utilizada por Marur (1999). Aos 70 dias após o transplante, período que correspondeu ao término da fase de crescimento da cultura, duas folhas opostas e expandidas de cada tratamento foram coletadas em madrugada posterior à irrigação (antes do alvorecer) para construção de curvas pressão volume (PV). Com a finalidade de se evitar algum problema de perda de continuidade da seiva nos vasos xilemáticos e manutenção da qualidade do material após a saturação, os pecíolos foram cortados submersos em água destilada em tubos de ensaios apropriados, sem haver contato da água com a folha, embalados e em seguida levados à geladeira até atingir à turgescência plena.

As curvas de PV foram determinadas utilizando-se câmara de pressão (Scholander et al., 1965), uma balança com precisão de 0,0001g e uma seringa com precisão de $0,2 \mu \mathrm{L}$ (Figura 8). As folhas foram colocadas na câmara e aplicados incrementos de pressão médios de $0,2 \mathrm{MPa}$, sendo a seiva coletada em seringa a cada incremento na pressão e registrada na balança. As curvas PV foram determinadas relacionando-se o inverso do potencial da água e o volume de seiva extraída pelo pecíolo (considerando a densidade igual a 1) quando ocorria o equilíbrio em relação a pressão aplicada. A construção das curvas permitiu a avaliação dos seguintes parâmetros (Boyer, 1995): potencial osmótico na turgescência plena $\left(\Psi_{\text {osm }}{ }^{100}\right)$ estimado pelo prolongamento da reta ajustada aos pontos da porção linear da curva pressão volume; potencial osmótico na turgescência zero $\left(\Psi_{\mathrm{osm}}^{0}\right)$ representado pelo ponto inicial da porção linear extrapolado ao eixo das ordenadas. 


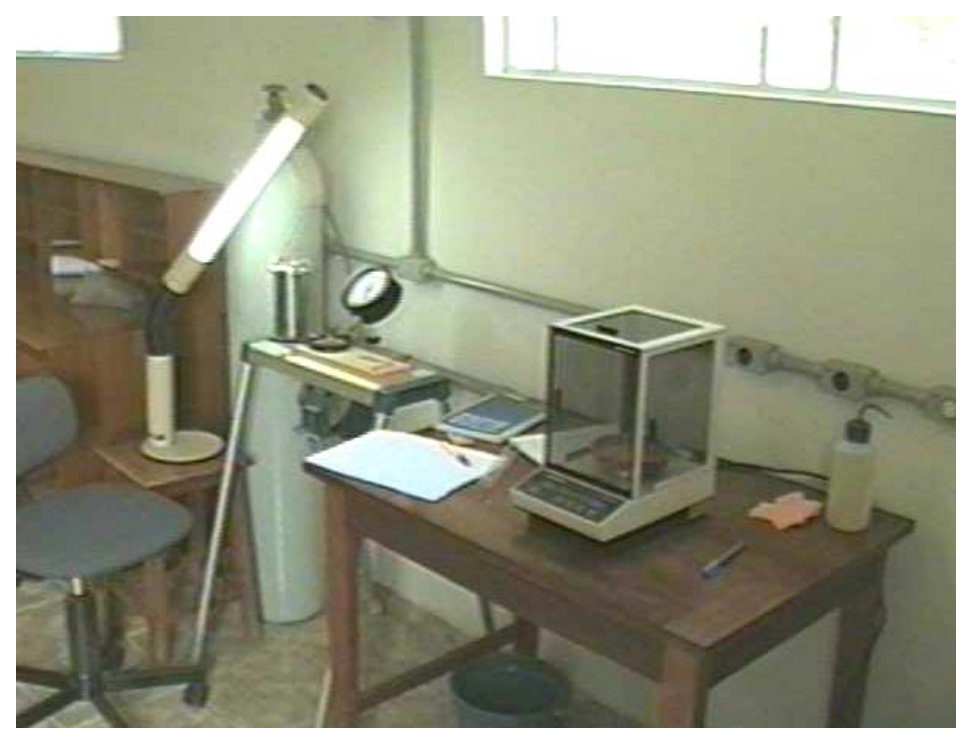

Figura 8 - Equipamentos utilizados na determinação das curvas pressão volume

\subsubsection{Variáveis relacionadas ao solo}

\subsubsection{Potencial mátrico}

O potencial mátrico médio foi determinado durante o ciclo da cultura para a profundidade de $20 \mathrm{~cm}$, monitorado a partir de tensiômetros. As leituras foram realizadas diariamente, sempre as 7:00h com o auxílio de tensímetros eletrônicos de punção como pode ser observado na Figura 9. 


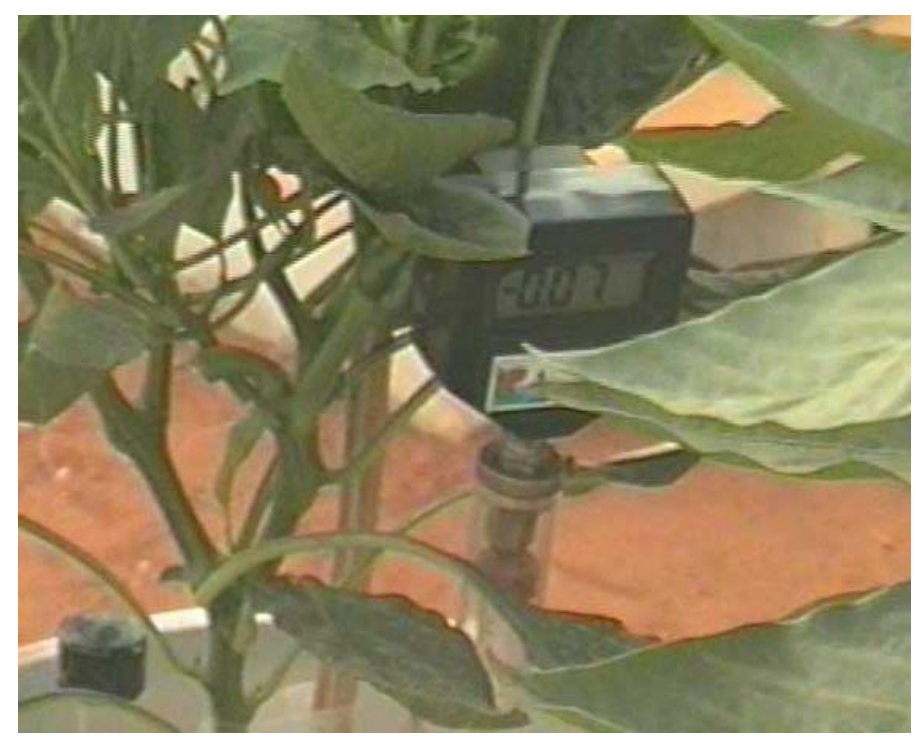

Figura 9 - Leitura da tensão da água do solo por meio de tensímetro eletrônico de punção

\subsubsection{Condutividade elétrica, pH e concentração iônica na solução do solo}

A condutividade elétrica da solução foi medida após o término de cada evento de irrigação, utilizando-se para extração, cápsulas porosas sob vácuo e condutivimetros de bancada microprocessados. A concentração dos níveis de nitrato, potássio na solução do solo foram determinadas semanalmente por utilização de testes rápidos e de todos os macronutrientes, quinzenalmente, em análises laboratoriais, conforme metodologia proposta pela EMBRAPA (1997).

\subsubsection{Análises estatística dos resultados}

Com a finalidade de realizar a análise de variância, inicialmente foi verificado se foram satisfeitas as exigências de seu modelo matemático, conforme as recomendações de Barbin (1994): aditividade do modelo, normalidade independência e homogeneidade da variância dos erros. As variáveis foram analisadas estatisticamente pelo teste de F, desdobrando as análises sempre que a interação foi significativa. Em virtude da disparidade da tendência dos resultados relativos aos diferentes solos 
utilizados no experimento II, tornou-se necessário desdobrar sempre a análise em relação ao referido fator.

O fator quantitativo relativo aos níveis de salinidade do solo foi analisado estatisticamente por meio de regressão, enquanto que os fatores solo e manejo da fertirrigação foram analisados por teste de comparação de médias (teste de Tukey). Como os fatores manejo e solo possuíam apenas dois tratamentos não se apresentaram letras indicadoras. A diferença entre ambos os tratamentos foi demonstrado apenas pelo teste de F. 


\title{
4 RESULTADOS E DISCUSSÃO
}

\subsection{Resultados dos testes iniciais (Experimento I)}

\subsubsection{Propriedades físico-hídricas e químicas dos materiais de solo utilizados}

\subsubsection{Material de solo retirado do Latossolo Vermelho Amarelo}

\begin{abstract}
No material de solo retirado da camada de 0 a $30 \mathrm{~cm}$ do perfil classificado como Latossolo Vermelho Amarelo obtiveram-se as seguintes características físicas: Granulometria: 18,5\% de argila, 12,0\% de silte e 69,5 de \% areia. Classificação segundo (USDA): Franco-arenoso ; densidade de partículas de $2,66 \mathrm{~g} \mathrm{~cm}^{-3}$ e densidade global igual a $1,10 \mathrm{~g} \mathrm{~cm}^{-3}$. Os valores de umidade do solo seco ao ar e capacidade máxima de retenção foram de $2,01 \%$ e $21,44 \%$ à base de peso, respectivamente.
\end{abstract}

A Figura 10 ilustra a curva característica de retenção da água no solo, determinada em vasos, sendo a umidade utilizada em sua construção representada com base em peso. A estimativa da curva por meio de regressão exponencial simples permitiu obter um coeficiente de determinação $\left(\mathrm{R}^{2}\right)$ de 0,9096 . 


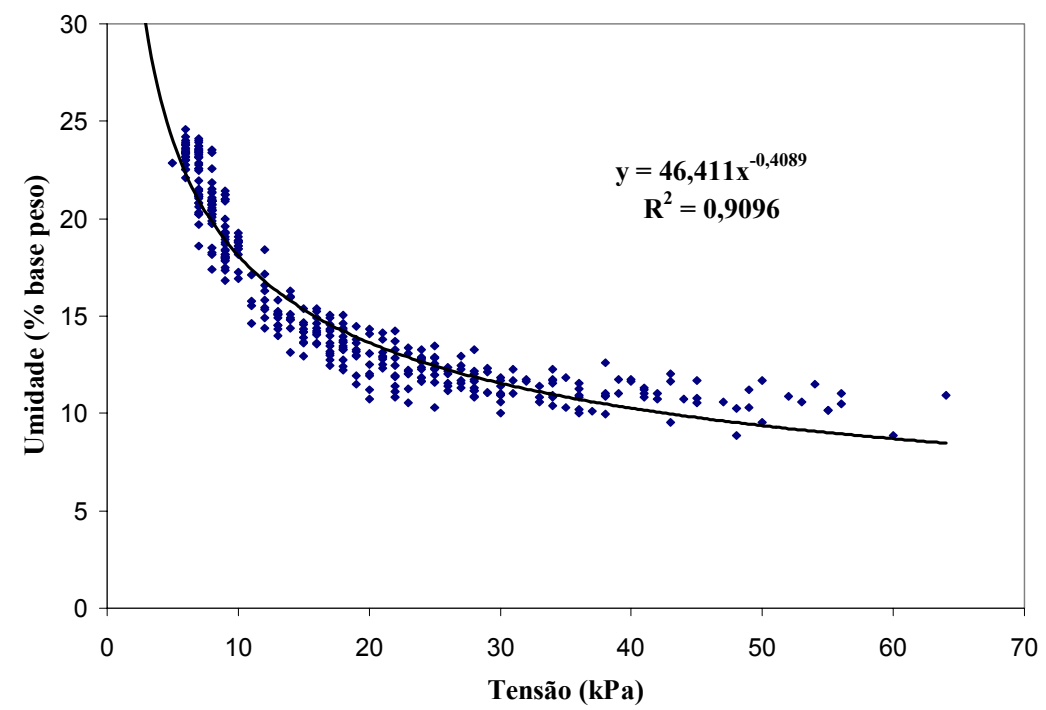

Figura 10 - Curva característica de retenção da água no Latossolo Vermelho Amarelo

Os valores de algumas propriedades químicas determinadas em amostras extraídas do material de solo retirado do Latossolo Vermelho Amarelo estão dispostos na Tabela 2.

Tabela 2. Propriedades químicas determinadas no Latossolo Vermelho Amarelo antes do testes preliminares

\begin{tabular}{|c|c|c|c|c|c|c|c|c|c|}
\hline $\begin{array}{c}\mathrm{pH} \\
\mathrm{CaCl}_{2}\end{array}$ & $\begin{array}{c}\mathrm{M} . \mathrm{O} \\
\mathrm{G} \mathrm{dm}^{-3}\end{array}$ & $\begin{array}{c}\mathrm{P} \\
\mathrm{mg} \mathrm{dm}^{-3}\end{array}$ & $\mathrm{~K}$ & $\mathrm{Ca}$ & $\mathrm{Mg}$ & $\begin{array}{c}\mathrm{H}+\mathrm{Al} \\
\mathrm{mmol}_{\mathrm{c}} \mathrm{dm}^{-3}\end{array}$ & SB & $\mathrm{T}$ & $\begin{array}{l}\mathrm{V} \\
(\%)\end{array}$ \\
\hline 4,6 & 21 & 5 & 1,8 & 24 & 9 & 31 & 34,8 & 65,8 & 53 \\
\hline
\end{tabular}

\subsubsection{Material de solo retirado da Terra Roxa Estruturada}

Para material de solo retirado da camada de 0 a $30 \mathrm{~cm}$ do perfil classificado como Terra Roxa Estruturada obtiveram-se as seguintes características físicas: Granulometria: $40,2 \%$ de argila, $17,5 \%$ de silte e $42,3 \%$ de areia. Classificação segundo (USDA): Franco-argiloso; densidade de partículas igual a $2,92 \mathrm{~g} \mathrm{~cm}^{-3} \mathrm{e}$ densidade global igual a $1,13 \mathrm{~g} \mathrm{~cm}^{-3}$. Os valores de umidade do solo seco ao ar e capacidade máxima de retenção foram de $5,68 \%$ e $27,66 \%$ à base de peso, respectivamente. 
A Figura 11 ilustra a curva característica de retenção da água no solo, determinada em vasos, sendo a umidade utilizada em sua construção representada com base em peso. A estimativa da curva por meio de regressão exponencial simples permitiu obter um coeficiente de determinação $\left(\mathrm{R}^{2}\right)$ de 0,9143 .

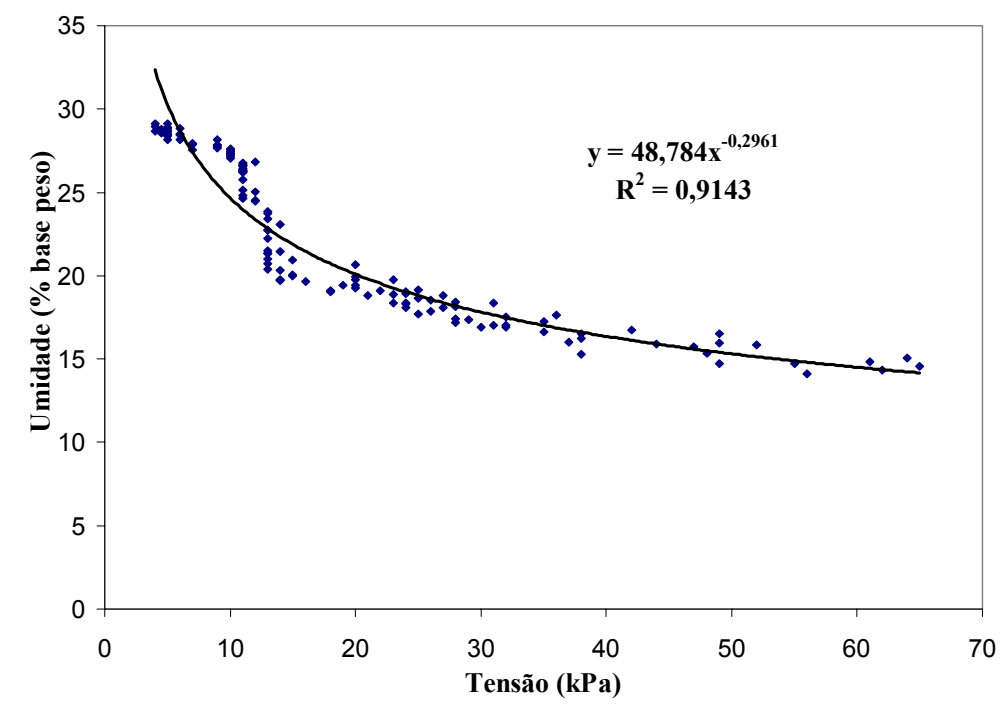

Figura 11 - Curva característica de retenção da água na Terra Roxa Estruturada

Os valores de algumas propriedades químicas determinadas em amostras extraídas do material de solo da Terra Roxa Estruturada estão dispostos na Tabela 3.

Tabela 3. Propriedades químicas determinadas na Terra Roxa Estruturada antes do testes preliminares

\begin{tabular}{cccccccccc}
\hline $\begin{array}{c}\mathrm{pH} \\
\mathrm{CaCl}_{2}\end{array}$ & $\begin{array}{c}\mathrm{M} \cdot \mathrm{O} \mathrm{g} \mathrm{dm}^{-3} \\
\mathrm{mg} \mathrm{dm}^{-3}\end{array}$ & $\mathrm{~K}$ & $\mathrm{Ca}$ & $\mathrm{Mg}$ & $\begin{array}{c}\mathrm{H}+\mathrm{Al} \\
\mathrm{mmol}_{\mathrm{c}} \mathrm{dm}^{-3}\end{array}$ & $\mathrm{SB}$ & $\mathrm{T}$ & $\begin{array}{c}\mathrm{V} \\
(\%)\end{array}$ \\
\hline 4,9 & 17 & 4 & 0,9 & 44 & 10 & 38 & 54,9 & 92,9 & 59 \\
\hline $\mathrm{MO}=$ matéria orgânica
\end{tabular}

\subsubsection{Curvas de salinização dos solos}

As Figuras 12 e 13 apresentam as curvas artificiais de salinização para os solos de textura mais arenosa e mais argilosa, respectivamente. Estes gráficos de dispersão possibilitam estimar as quantidades de sais a serem adicionadas com a finalidade de obter-se uma condutividade elétrica no extrato de saturação desejável com 
boa precisão. Nota-se que para ambos os solos utilizados o coeficiente de determinação foi superior a 0,97 .

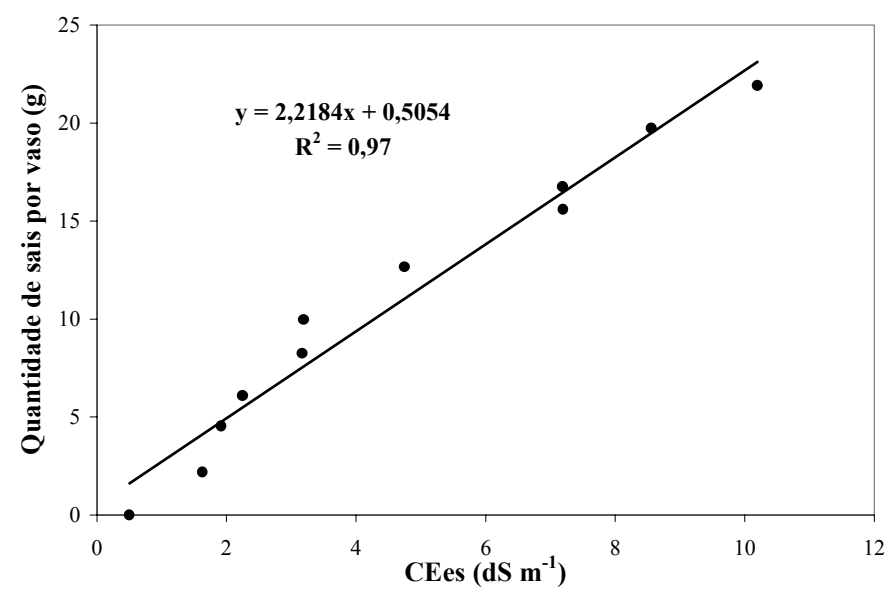

Figura 12 - Curva de salinização artificial para o Latossolo Vermelho Amarelo

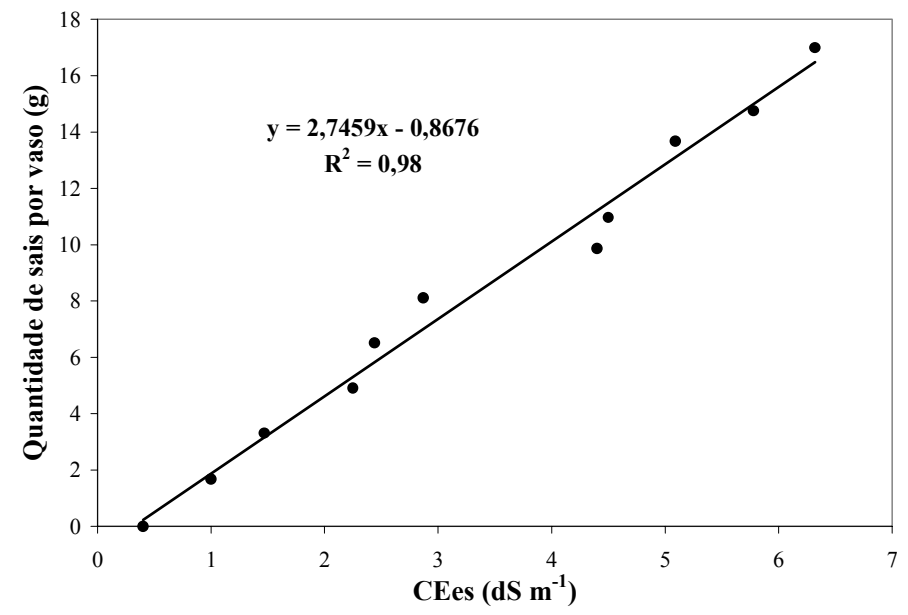

Figura 13 - Curva de salinização artificial para a Terra Roxa Estruturada

Na Figura 14 e 15 pode-se observar, por meio de um gráfico de dispersão, a relação entre a condutividade elétrica do extrato da pasta de saturação estimada por meio da equação 1 e, a condutividade elétrica do extrato de saturação medida 
experimentalmente para o Latossolo Vermelho-Amarelo e para a Terra Roxa Estruturada, respectivamente.

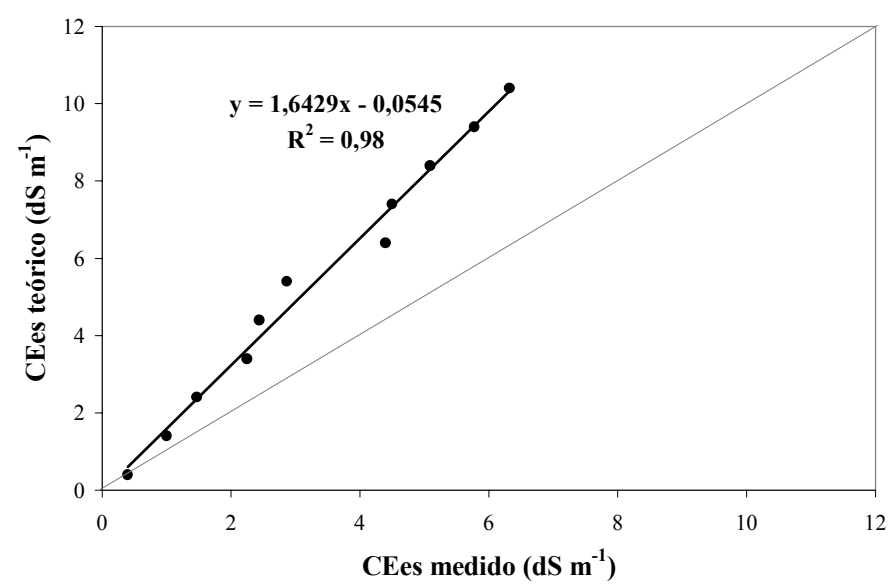

Figura 14 - Relação entre a condutividade elétrica (CE) do extrato da pasta de saturação calculada teoricamente e medida experimentalmente para o Latossolo Vermelho Amarelo

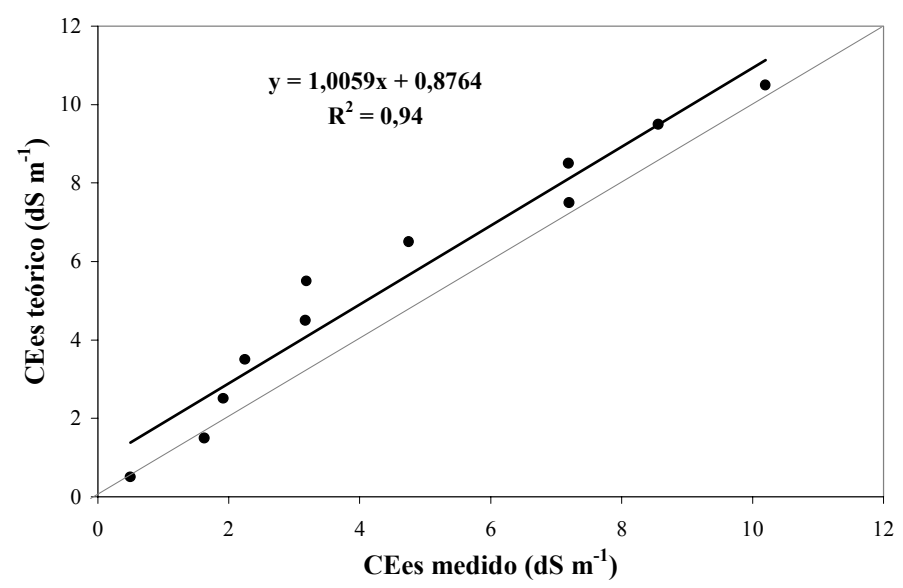

Figura 15 - Relação entre a condutividade elétrica (CE) do extrato da pasta de saturação calculada teoricamente e medida experimentalmente para a Terra Roxa Estruturada

Comparando os resultados obtidos para os solos estudados, esperava-se que no solo mais arenoso, ou seja, o Latossolo Vermelho Amarelo, a relação entre a condutividade elétrica estimada pela equação 1 e a medida fosse mais próxima a 1 , mostrando uma menor adsorção iônica em relação ao solo mais argiloso, em virtude da menor capacidade de troca deste solo. Entretanto, este fato não foi observado. Este fato 
pode ter ocorrido devido a maior quantidade de íons adsorvidos pelo Latossolo Vermelho-Amarelo em relação à Terra Roxa Estruturada, visto que, este solo encontrava-se com a soma de bases proporcionalmente inferior, sendo necessário maiores quantidades de íons para saturar o complexo sortivo. Outro aspecto a ser observado é que a fórmula representada pela equação 1 é um modelo geral, assim sendo, os sais utilizados podem não seguir o mesmo comportamento.

$\mathrm{Na}$ Terra Roxa Estruturada a estimativa da condutividade elétrica no extrato de saturação foi satisfatória em relação aos valores medidos, subestimando estes em apenas $0,6 \%$ com $\mathrm{R}^{2}$ acima de 0,94 . Nota-se que o cálculo teórico superestimou o valor real. Este fato se deve possivelmente à adsorção de íons no complexo coloidal do solo, que consequentemente diminui a concentração dessa solução e sua respectiva condutividade elétrica.

A Figura 16 ilustra o monitoramento da condutividade elétrica da solução do Latossolo Vermelho Amarelo amostrada ao longo dos dias após a salinização dos vasos. Verificou-se que os processos de adsorção para os diferentes níveis de salinidade apresentaram características distintas.

Para os diversos níveis de salinidade estudados obteve-se uma tendência de queda entre o momento da salinização e o segundo dia de extração. De maneira geral, o estudo permitiu concluir que após o segundo dia da salinização o sistema encontravase em equilíbrio osmótico, portanto, após dois dias da salinização do solo pode-se iniciar um estudo posterior de tolerância de determinada cultura à salinidade. 


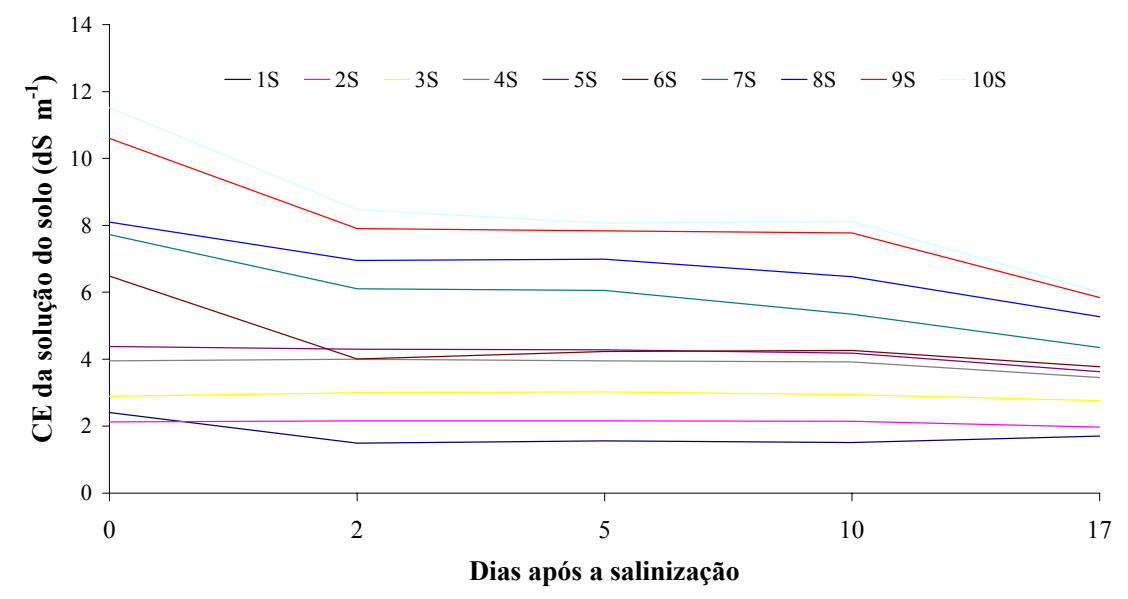

Figura 16 - Condutividade elétrica ao longo dos dias, da solução do Latossolo Vermelho Amarelo extraída com o extrator de cápsula porosa

Dessa forma pode-se verificar que a salinização artificial do solo requer a elaboração de curvas para que sejam produzidos solos com a condutividade elétrica no extrato de saturação desejadas. Cálculos teóricos podem acarretar erros em virtude de diversos fatores interferentes. Na salinização artificial de um solo para um posterior estudo de tolerância é necessário um prazo de dois dias após o momento da adição da solução salinizadora para que o solo alcance o equilíbrio osmótico para maioria dos tratamentos, entretanto, para os níveis de salinidade de 8 a $10 \mathrm{dS} \mathrm{m}^{-1}$ observou-se que ocorreu um pequeno declínio na salinidade do solo, possivelmente em virtude de processos de adsorção potencializado pela alta concentração na solução do solo. Nesse caso torna-se necessário um ajuste antes do início do estudo de tolerância.

\subsubsection{Teste preliminar dos extratores na determinação da salinidade do solo}

Pode-se verificar nas Figuras 18 e 20 que, de maneira geral, os métodos de estimativa da salinidade do solo estudado, ou seja, as medidas de condutividade elétrica da solução diluída 1:2 e da condutividade elétrica da solução do solo obtida com extrator de cápsula porosa, apresentaram boa correlação quando comparados com o método da condutividade elétrica do extrato de saturação do Latossolo Vermelho Amarelo. 
Na Figura 17 observa-se um coeficiente de determinação $\left(\mathrm{R}^{2}\right)$ igual à 0,92 , quando realizada uma regressão linear entre os valores de condutividade da solução diluída 1:2 e do extrato de saturação, em que as leituras do método 1:2 correspondem, em média, a 15,48\% do método padrão. Quando foram corrigidos, os diferentes níveis de umidade para umidade da pasta saturada e construíu-se um diagrama de dispersão com uma reta de ajuste linear e seu correspondente coeficiente de determinação $\left(\mathrm{R}^{2}\right)$ que objetiva comparar os valores entre os métodos (Figura 18). Neste caso percebeu-se que a condutividade elétrica do extrato de saturação, estimada a partir das leituras de condutividade elétrica do método solução diluída 1:2, com a umidade corrigida, superou a condutividade elétrica do extrato de saturação medida em cerca de $25 \%$ com um $\mathrm{R}^{2}$ igual a 0,92 . Utilizou-se afim de auxiliar a comparação os métodos estatísticos preconizados por Willmott (1981) e Kolmogorov \& Smirnov apresentados por Campos (1983); os mesmos estão representados simbolicamente pelos termos Id e $\mathrm{D}$, respectivamente. $\mathrm{O}$ valor de Id igual a 0,91 representa que os pontos não mostraram dispersão elevada em relação a reta 1:1 e o valor de D igual a 0,24 , quando comparado pelos valores tabelados no teste, representa que os métodos comparados são diferentes significativamente a $5 \%$ de probabilidade.

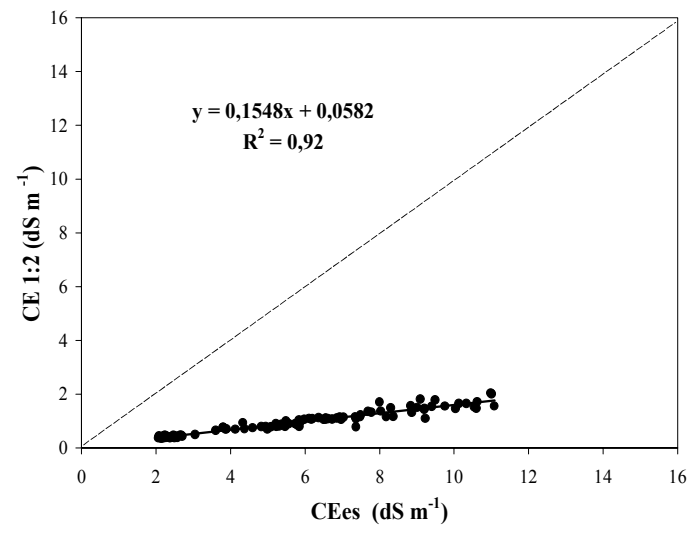

Figura 17 - Relação entre os valores de condutividade elétrica do extrato de saturação (CEes) e condutividade elétrica da suspensão 1:2 (CE 1:2) para o Latossolo Vermelho Amarelo 


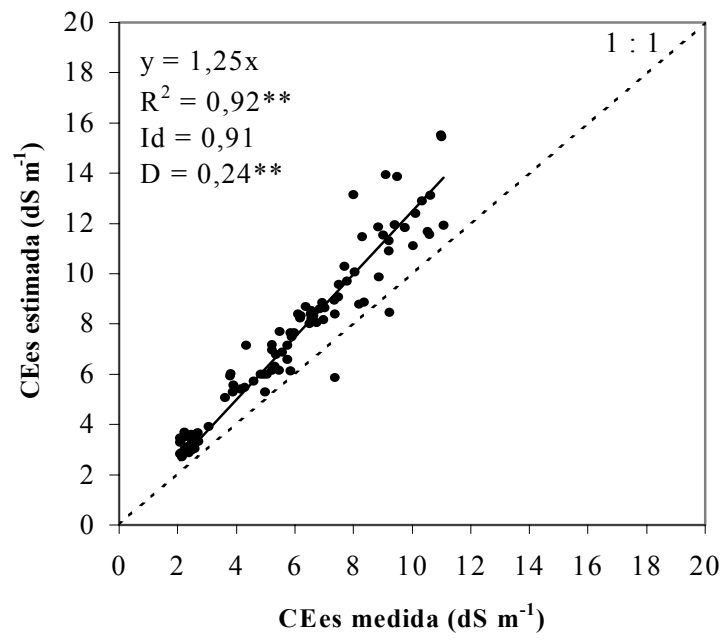

Figura 18 - Relação entre os valores de condutividade elétrica do extrato de saturação medida e estimada a partir da condutividade elétrica da suspensão 1:2, com correção em função da umidade para o Latossolo Vermelho Amarelo

Possivelmente, este fato se deveu à solubilização do carbonato de cálcio aplicado no início do experimento, visto que o volume de água utilizado neste método é bem maior que o utilizado no método padrão, em torno de 7,7 vezes para o solo utilizado, o qual possui umidade média da pasta saturada de $26 \%$ a base de peso.

Conforme Hoorn \& Alphen (1994) o $\mathrm{CaCO}_{3}$ é responsável por um incremento entre 0,8 a $1,0 \mathrm{dS} \mathrm{m}^{-1}$ na condutividade elétrica da suspenção $1: 2$, visto que o maior volume de água utilizado proporciona a solubilização deste sal. De maneira geral pode-se observar o mesmo comportamento na diferença entre a condutividade elétrica do extrato de saturação determinada e estimada com base na condutividade elétrica medida na suspensão 1:2 após correção de umidade.

As leituras de condutividade elétrica da solução do solo obtida com o extrator de cápsula porosa correlacionadas ao método padrão, apresentaram um coeficiente de determinação $\left(\mathrm{R}^{2}\right)$ igual a 0,94 , obtendo-se, em média, valores de condutividade elétrica da solução do solo superiores à condutividade elétrica do extrato de saturação, em 19,35\% (Figura 19). Após a correção das diferentes umidades, inerentes aos métodos, pode-se notar que os valores da condutividade elétrica do extrato de saturação estimados pelas leituras de condutividade elétrica da solução do solo 
extraídos pelas cápsulas, com correção para umidade da pasta saturada e a condutividade elétrica do extrato de saturação medida apresentaram coeficiente angular igual a 1, e um $\mathrm{R}^{2}$ de 0,93 (Figura 20). O valor de Id de 0,98 indica uma leve dispersão dos dados em relação a reta 1:1 e o valor de $\mathrm{D}$ igual a 0,10 mostrou que ambos os métodos não diferiram significativamente. Neste caso, a solubilização do carbonato de cálcio pode não ter acontecido em função da pequena diferença no volume de água nos dois métodos, quando comparado ao método da suspensão 1:2.

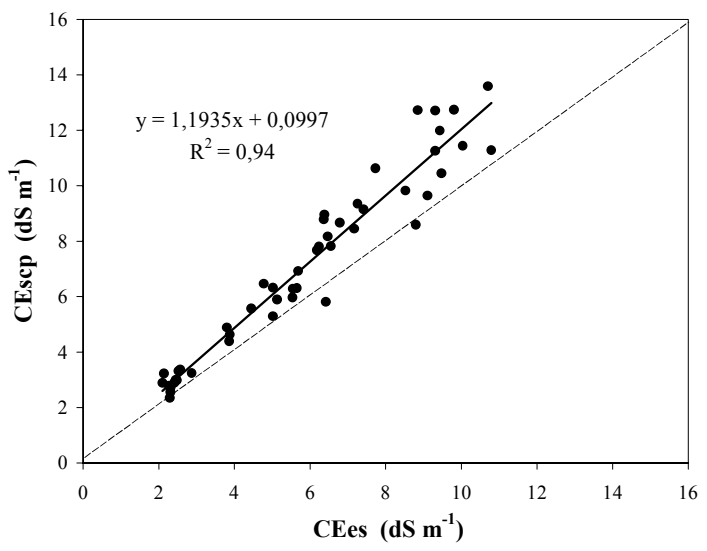

Figura 19 - Relação entre os valores de condutividade elétrica do extrato de saturação (CEes) e condutividade elétrica da solução obtida com extrator de cápsula (CEscp) para o Latossolo Vermelho Amarelo

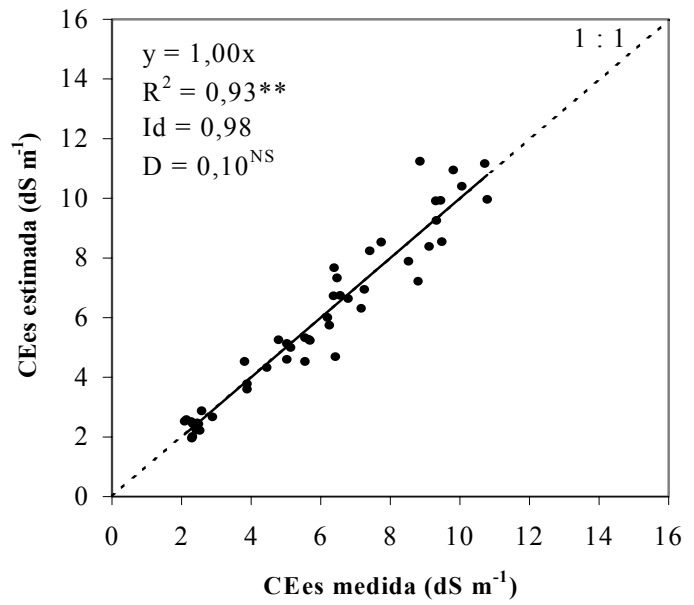

Figura 20 - Relação entre os valores de condutividade elétrica do extrato de saturação, medida e estimada a partir da condutividade elétrica da solução obtida com extrator de cápsula com correção em função da umidade para o Latossolo Vermelho Amarelo 
Segundo Rhoades et al. (1999) o método da suspensão 1:2 recomendado por Sonnevelt \& Ende (1971) apresenta como inconveniente a diferença elevada entre o conteúdo relativo de água, quando o método é empregado em um solo arenoso e em um solo argiloso e comparado com a quantidade de água presente na pasta saturada.

Esta observação evidencia-se como mais uma vantagem da utilização de extratores de cápsulas porosas, visto que quando extraída a solução do solo, o solo se encontra em umidade equivalente à umidade no momento da absorção da solução nutritiva pelas plantas, além de que os íons solubilizados em ambas situações citadas serão os mesmos. Portanto, o método de medida da condutividade elétrica da solução extraída por cápsulas porosas poderá ser utilizado, mesmo que no solo ocorra presença de sais de baixa solubilidade, bastando, pois, que sejam conhecidas a umidade do solo no momento da extração e a umidade da pasta saturada.

Desta forma, e por intermédio da correção da umidade, pode ser estimada a condutividade elétrica do extrato de saturação facilitando, assim, a comparação com trabalhos publicados de tolerância de culturas e classificação dos solos quanto à salinidade. No teste das cápsulas quanto a uma possível contaminação, constatou-se que as cápsulas de cerâmica utilizadas não alteraram a leitura da condutividade elétrica das soluções, nem de água destilada.

A utilização das cápsulas porosas mostrou-se de fácil utilização, visto que o solo se encontrava próximo à capacidade máxima de retenção, o que corresponde às condições de cultivo em ambiente protegido e em que se utilizam irrigações localizadas e de alta freqüência. Recomenda-se a utilização do método de medição da condutividade elétrica da solução obtida com extrator de cápsula, visto a sua facilidade, versatilidade e praticidade, em relação aos demais métodos. 


\subsection{Resultados do cultivo em estufa plástica (Experimento II)}

\subsubsection{Aspectos químicos na solução do solo}

As características químicas dos solos utilizados no ensaio foram influenciadas significativamente pelos níveis de salinidade impostos ao início do experimento. Todas as variáveis analisadas, ou seja, condutividade elétrica da solução do solo, $\mathrm{pH}$ e concentração de macronutrientes apresentaram diferenças ao nível de $1 \%$ de probabilidade pelo teste de F (Tabela 4). Observou-se que, para maioria das variáveis, os tratamentos relativos ao fator solo, assim como a interação entre o fator salinidade e o fator solo, apresentaram diferenças significativas, dessa forma, foram desdobradas as análises de variância e regressões em relação aos tratamentos estudados.

Tabela 4. Resumo da análise de variância para a condutividade elétrica e concentrações de macronutrientes médias ao longo do ciclo na solução do solo.

\begin{tabular}{|c|c|c|c|c|c|c|c|c|}
\hline \multirow{2}{*}{$\begin{array}{l}\text { Causa da } \\
\text { Variação }\end{array}$} & \multicolumn{8}{|c|}{ Estatística F } \\
\hline & CE - sol & $\mathrm{K}$ & $\mathrm{Ca}$ & $\mathrm{Mg}$ & $\mathrm{S}$ & $\mathrm{P}$ & $\mathrm{NO}_{3}$ & $\mathrm{pH}$ \\
\hline \multicolumn{9}{|l|}{ Tratamentos: } \\
\hline Blocos & 0,21 & 1,03 & 0,06 & 1,15 & 0,82 & 1,09 & 1,10 & 0,32 \\
\hline Salinidade (N) & $154,70 * *$ & $25,05 * *$ & $22,69 * *$ & $16,74^{* *}$ & $8,53 * *$ & $4,56 * *$ & $43,25 * *$ & $6,34 * *$ \\
\hline Solo (S) & $68,51 * *$ & $514,84 * *$ & 1,06 & 0,71 & $122,74 * *$ & $79,67 * *$ & $21,91 * *$ & $11,70^{* *}$ \\
\hline Manejo (M) & 0,03 & 0,53 & 0,71 & 0,44 & 0,55 & 0,54 & $10,94 * *$ & 0,59 \\
\hline \multicolumn{9}{|l|}{ Interações: } \\
\hline $\mathrm{N} \times \mathrm{S}$ & $5,21 *$ & $16,51 * *$ & 1,07 & 1,36 & $6,23 * *$ & 1,45 & $13,66^{* *}$ & 0,22 \\
\hline $\mathrm{N} \times \mathrm{M}$ & $2,16^{*}$ & 0,75 & 0,52 & 0,54 & 0,30 & 1,71 & $3,89 * *$ & 1,10 \\
\hline $\mathrm{S} \times \mathrm{M}$ & 0,86 & 0,11 & 1,95 & 0,58 & 0,47 & 0,01 & 1,45 & 2,81 \\
\hline $\mathrm{N} \times \mathrm{S} \times \mathrm{M}$ & 1,51 & 0,35 & 0,01 & 0,59 & 0,14 & 1,30 & 1,51 & 1,34 \\
\hline
\end{tabular}

\subsubsection{Aspectos químicos para o Latossolo Vermelho Amarelo (franco-arenoso)}

Os valores médios da condutividade elétrica e concentração dos macronutrientes, ao longo do ciclo de cultivo de pimentão, na solução do solo francoarenoso foram influenciados significativamente pelos níveis de salinidade impostos ao início do tratamento. $\mathrm{Na}$ Tabela 5 são demonstradas as diferenças observadas após 
análise pelo teste de $\mathrm{F}$; verifica-se que as variáveis diferiram entre si ao nível de $1 \%$ de significância. Entretanto entre os manejos de fertirrigação empregados apenas a variável concentração de nitrato mostrou diferença, além do efeito conjunto entre salinidade e manejo, apresentando uma média $25,67 \mathrm{mmol}_{\mathrm{c}} \mathrm{L}^{-1}$ para o manejo da fertirrigação tradicional contra $30,82 \mathrm{mmol}_{\mathrm{c}} \mathrm{L}^{-1}$ para o manejo da fertirrigação controlado. Esses resultados eram esperados, em virtude da adição crescente de fertilizantes no momento da salinização no início do experimento afim de incrementar a salinidade inicial do solo. Conforme Rhoades et al. (1999) os valores de condutividade elétrica são diretamente proporcionais à soma dos cátions presentes na solução do solo.

Tabela 5. Resumo da análise de variância para a condutividade elétrica e concentrações de macronutrientes médias ao longo do ciclo na solução do solo francoarenoso.

\begin{tabular}{|c|c|c|c|c|c|c|c|c|}
\hline \multirow{2}{*}{$\begin{array}{l}\text { Causa da } \\
\text { Variação }\end{array}$} & \multicolumn{8}{|c|}{ Estatística F } \\
\hline & $\mathrm{CE}-$ sol & $\mathrm{K}$ & $\mathrm{Ca}$ & $\mathrm{Mg}$ & $\mathrm{S}$ & $\mathrm{P}$ & $\mathrm{NO}_{3}$ & $\mathrm{pH}$ \\
\hline \multicolumn{9}{|l|}{ Tratamentos: } \\
\hline Blocos & 0,36 & 0,90 & 0,06 & 0,42 & 0,24 & 0,56 & 0,96 & 2,57 \\
\hline Salinidade (N) & $61,21 * *$ & $21,08 * *$ & $9,61 * *$ & $7,87 * *$ & $7,37 * *$ & $5,67 * *$ & $47,20 * *$ & $5,83^{* *}$ \\
\hline Manejo (M) & 0,37 & 0,29 & 1,06 & 0,07 & 0,05 & 0,62 & $9,02 * *$ & 2,83 \\
\hline \multicolumn{9}{|l|}{ Interações: } \\
\hline $\mathrm{N} \times \mathrm{M}$ & 1,20 & 0,48 & 0,57 & 0,34 & 0,25 & 0,91 & $4,01 * *$ & 1,19 \\
\hline
\end{tabular}

A Figura 21 ilustra a dispersão dos dados e equação de ajuste para os valores médios ao longo do ciclo de condutividade elétrica, de potássio, de cálcio, de magnésio, de enxofre e de fósforo na solução do solo franco-arenoso. Tanto a condutividade elétrica quanto os demais macronutrientes apresentam um ajuste linear crescente em função do incremento da salinidade inicial do solo.

Os valores de condutividade elétrica média na solução do solo francoarenoso, ao longo do ciclo da cultura, mostraram uma forte correlação com a salinidade inicial do solo, apresentando um coeficiente de determinação $\left(\mathrm{R}^{2}\right)$ significativo a $1 \%$ da probabilidade e com valor de 0,93, o que pode ser comprovado visualmente pela pequena dispersão dos pontos em relação a linha de ajuste (Figura $21 \mathrm{~A}$ ). A reta de ajuste apresenta uma tendência de incremento da condutividade elétrica na solução do 
solo a medida que a salinidade do solo aumenta com comportamento semelhante para ambos os manejos de fertirrigação os quais não diferiram significativamente pelo teste de F.

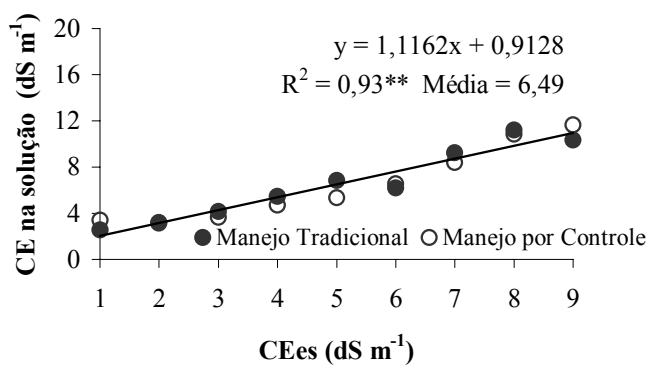

(A)

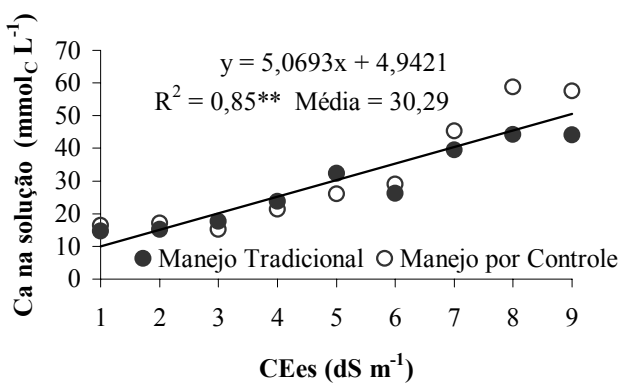

(C)

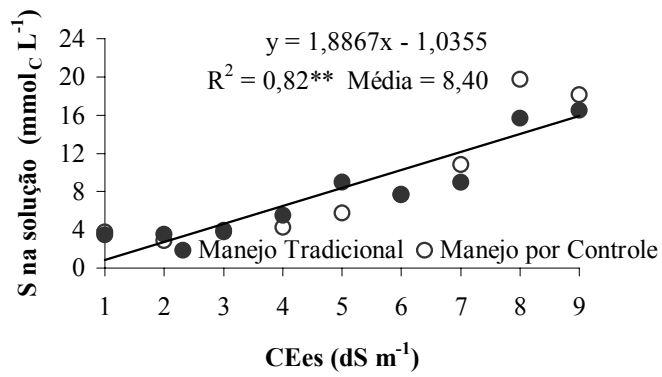

(E)

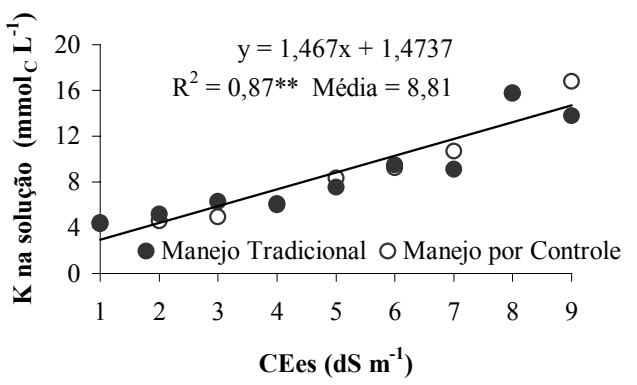

(B)

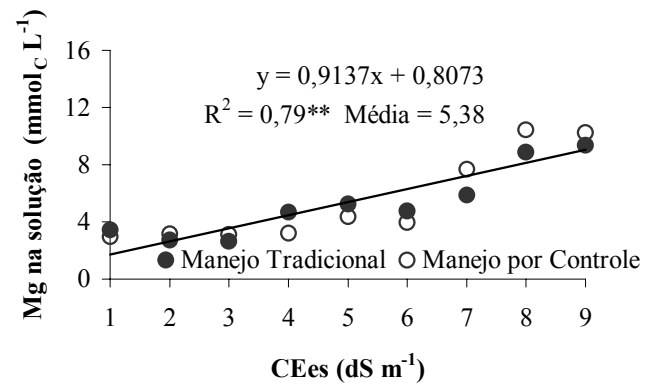

(D)

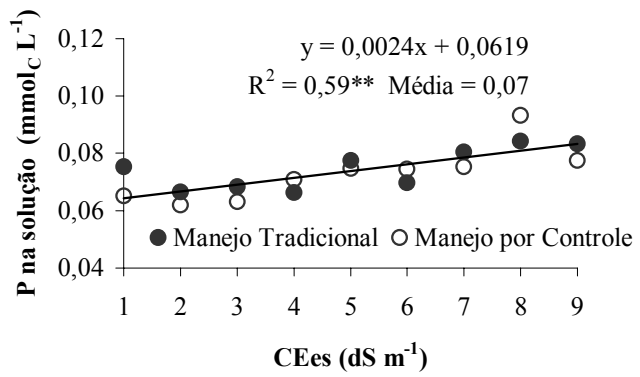

(F)

Figura 21 - Diagrama de dispersão e equação de ajuste para o solo franco-arenoso entre: (A) condutividade elétrica, (B) potássio, (C) cálcio, (D) magnésio, (E) enxofre e (F) fósforo na solução do solo e a salinidade inicial do solo para os diferentes manejos de fertirrigação

Na Figura 21, os gráficos (B), (C), (D), (E) e (F) ilustram a regressão para as concentrações de potássio, cálcio, magnésio, enxofre e fósforo, respectivamente. Todas as concentrações dos nutrientes citados apresentaram um ajuste linear crescente para ambos os manejos de fertirrigação. A correlação entre as concentrações 
determinadas na solução do solo e a salinidade inicial foi confirmada a partir da significância nos coeficientes de determinação, todos significativos ao nível de $1 \%$. Os valores de $\mathrm{R}^{2}$ variaram entre 0,87 e 0,59, para os nutrientes potássio e fósforo, respectivamente.

O nitrato na solução do solo também apresentou concentração crescente com o incremento na salinidade do solo franco-arenoso para os diferentes manejos de fertirrigação empregados (Figura 22). Entretanto o ajuste entre os manejos diferiram apresentando-se linear para o manejo tradicional e polinomial quadrático para o manejo controlado. Todavia, pode-se perceber que os pontos relacionados à salinidade de até $6 \mathrm{dS} \mathrm{m}^{-1}$ no extrato de saturação conferem uma concentração semelhante aos níveis de salinidade, ou seja, em torno de $15 \mathrm{mmol}_{\mathrm{c}} \mathrm{L}^{-1}$. Em ambas as regressões, o nitrato na solução e a salinidade mostram um boa correlação com $\mathrm{R}^{2}$ igual a 0,74 para o manejo tradicional e 0,89 para o manejo controlado. A menor dispersão dos dados médios em relação a curva de ajuste para o manejo controlado pode ser atribuída as correções nas doses do nutriente específico ao longo do ciclo de cultivo.

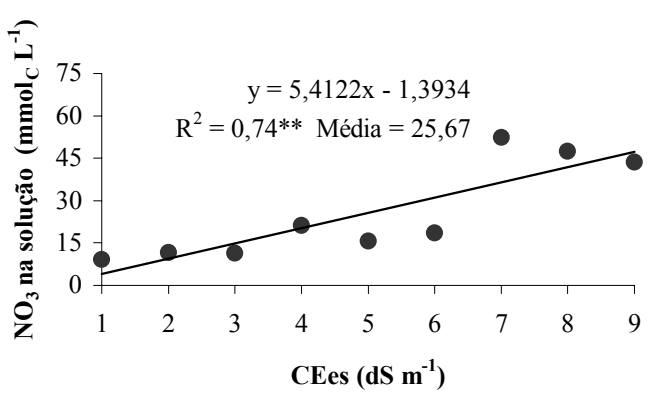

(A)

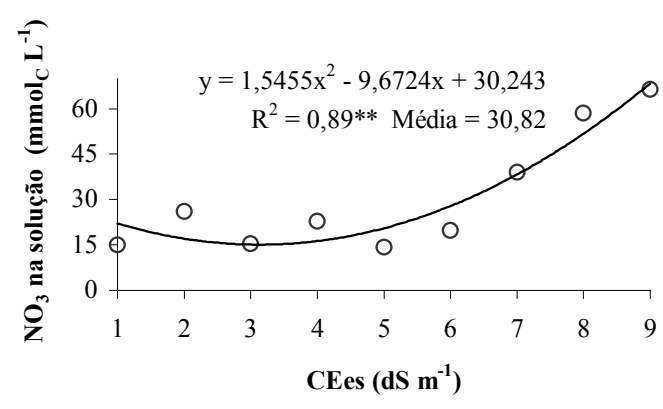

(B)

Figura 22 - Diagrama de dispersão e equação de ajuste para o solo franco-arenoso entre o nitrato na solução do solo e a salinidade inicial do solo para: (A) o manejo de fertirrigação tradicional e (B) o manejo de fertirrigação controlado

Os resultados de pH na solução do solo em função da salinidade para o solo franco-arenoso e para os diferentes manejos da fertirrigação estão apresentados na Figura 23. Os valores médios para os diferentes níveis de salinidade determinaram uma tendência linear decrescente com incremento da salinidade. Apesar do vácuo na câmara do extrator interferir indiretamente no $\mathrm{pH}$, como é exposto por Grover \& Lamborn 
(1970), este decréscimo no pH pode ser atribuído a adição crescente de ácido fosfórico e sulfatos em relação aos níveis de salinidade no momento da salinização do solo.

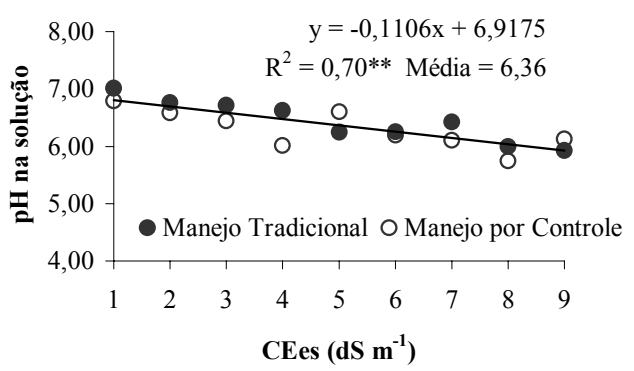

Figura 23 - Diagrama de dispersão e equação de ajuste para o solo franco-arenoso entre o pH da solução do solo e a salinidade inicial do solo para para os diferentes manejos de fertirrigação

\subsubsection{Aspectos químicos para Terra Roxa Estruturada (franco-argiloso)}

$\mathrm{Na}$ Tabela 6 pode-se observar que a salinidade inicial do solo francoargiloso promoveu diferenças significativas na condutividade elétrica da solução do solo, no pH e na concentração da maioria dos macronutrientes estudados, excetuando-se o magnésio e fósforo. Não ocorreu diferenças para os diferentes manejos estudados, entretanto, houve efeito significativo da interação entre salinidade e manejo, indicando que a dispersão foi diferente à cada manejo, porém a tendência dos dados não diferem.

Tabela 6. Resumo da análise de variância para a condutividade elétrica e concentrações de macronutrientes médias ao longo do ciclo na solução do solo francoargiloso

\begin{tabular}{|c|c|c|c|c|c|c|c|c|}
\hline \multirow{2}{*}{$\begin{array}{l}\text { Causa da } \\
\text { Variação }\end{array}$} & \multicolumn{8}{|c|}{ Estatística F } \\
\hline & CE - sol & $\mathrm{K}$ & $\mathrm{Ca}$ & $\mathrm{Mg}$ & $\mathrm{S}$ & $\mathrm{P}$ & $\mathrm{NO}_{3}$ & $\mathrm{pH}$ \\
\hline \multicolumn{9}{|l|}{ Tratamentos: } \\
\hline Blocos & 0,71 & 0,84 & 0,62 & 1,14 & 0,61 & 1,14 & 0,29 & 0,93 \\
\hline Salinidade (N) & $161,69^{* *}$ & $6,51 * *$ & $17,86^{* *}$ & 11,36 & $5,81 * *$ & 1,31 & $6,50 * *$ & $2,41 *$ \\
\hline Manejo (M) & 0,78 & 0,91 & 1,06 & 0,01 & 0,03 & 0,39 & 2,31 & 0,71 \\
\hline \multicolumn{9}{|l|}{ Interações: } \\
\hline $\mathrm{N} \times \mathrm{M}$ & $4,65 * *$ & 2,01 & 0,76 & 0,37 & 1,37 & 1,90 & 1,11 & 1,36 \\
\hline
\end{tabular}




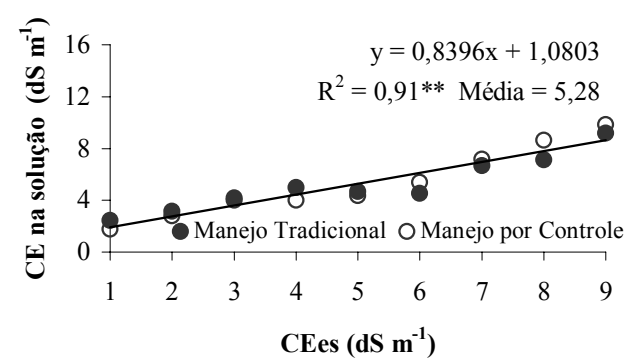

(A)

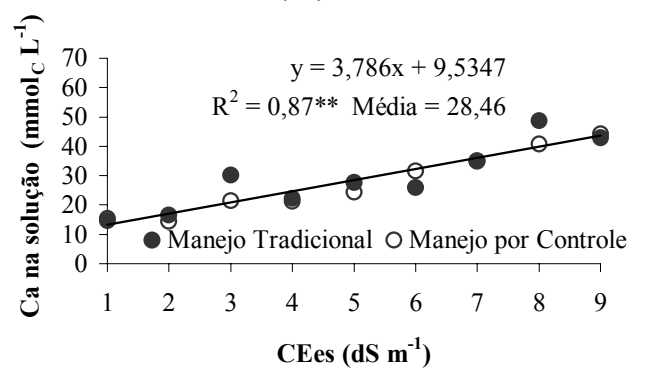

(C)

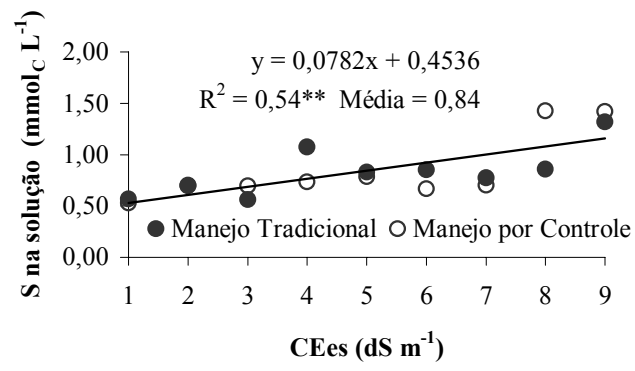

(E)

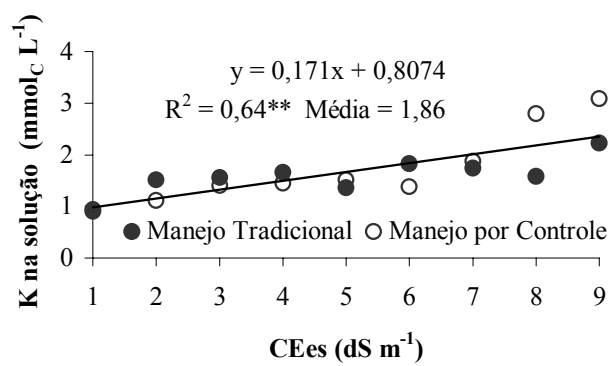

(B)

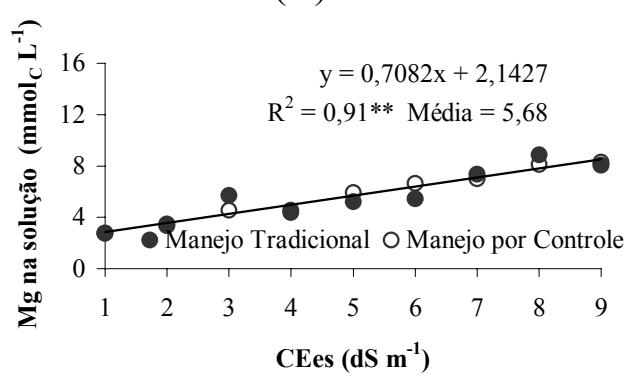

(D)

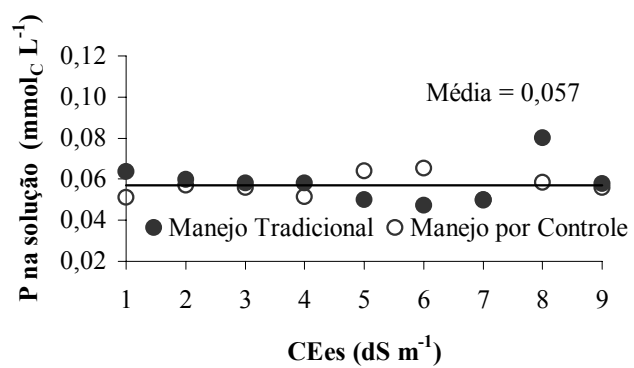

(F)

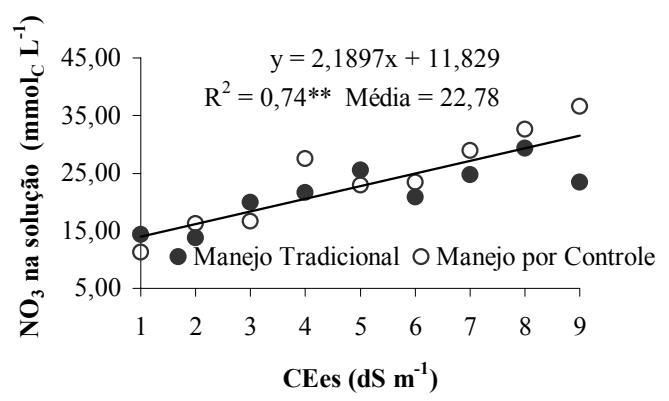

(G)

Figura 24 - Diagrama de dispersão e equação de ajuste para o solo franco-argiloso entre: (A) condutividade elétrica, (B) potássio, (C) cálcio, (D) magnésio, (E) enxofre, $(F)$ fósforo e $(G)$ nitrato na solução do solo e a salinidade inicial do solo para os diferentes manejos de fertirrigação

Os diagramas de dispersão dispostos na Figura 24 apresentam ajustes lineares crescentes para os macronutrientes estudados. Em todos os diagramas as 
variáveis apresentaram correlação em relação à salinidade, visto que os coeficientes de determinação foram significativos, apesar de alguns casos, como o enxofre, o valor de $\mathrm{R}^{2}$ ser de 0,54 , causado pela dispersão em relação a reta de ajuste. Na Figura $24(\mathrm{~F})$ pode-se notar que o fósforo não apresentou diferenças significativas entre a sua concentração e a salinidade inicial do solo e que sua média foi igual a $0,057 \mathrm{mmol}_{\mathrm{c}} \mathrm{L}^{-1}$. Esse fato deve-se a maior fixação do fósforo na Terra Roxa Estruturada, quando comparada ao Latossolo Vermelho-Amarelo.

Os resultados de pH na solução do solo em função da salinidade para o solo franco-argiloso e para os diferentes manejos da fertirrigação podem se observados na Figura 25. Os valores médios para os diferentes níveis de salinidade determinaram uma tendência linear decrescente com incremento da salinidade; assim como ocorreu no solo franco-arenoso, este decréscimo no $\mathrm{pH}$ pode ser atribuído a adição crescente de ácido fosfórico e sulfatos em relação aos níveis de salinidade no momento da salinização do solo. A correlação foi significativa, entretanto $\mathrm{o} \mathrm{R}^{2}$ de 0,49 mostra uma maior dispersão do pH para o solo franco-argiloso. Comparando a redução entre o pH do solo franc0-arenoso e franco argiloso nota-se uma menor inclinação na reta, isso deve-se ao maior poder tampão do solo com maior quantidade de partículas de argila.

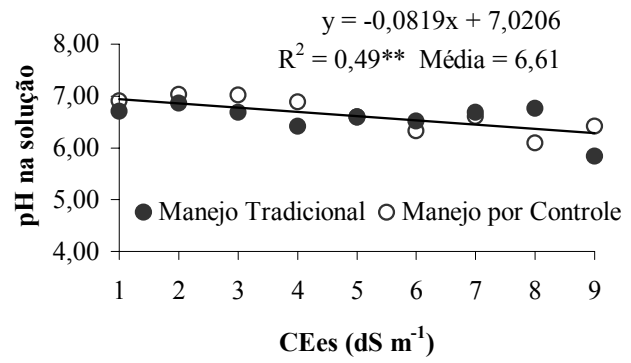

Figura 25 - Diagrama de dispersão e equação de ajuste para o solo franco-argiloso entre o pH da solução do solo e a salinidade inicial do solo os diferentes manejos de fertirrigação

\subsubsection{Monitoramento da salinidade do solo}

Na Figura 26 estão apresentados os valores de condutividade elétrica da solução do solo extraída por meio de cápsulas cerâmicas instaladas a $20 \mathrm{~cm}$ de 
profundidade para os diferentes manejos de fertirrigação ao longo do ciclo da cultura. Nota-se que para o solo franco-arenoso as linhas que se referem a condutividade elétrica da solução do solo ao longo do ciclo, para as diferentes salinidade iniciais do solo, retratam picos mais acentuados que no solo franco argiloso, esse fato pode ser atribuído a maior quantidade de argila presente no segundo solo a qual proporciona à solução um maior equilíbrio, em virtude da maior possibilidade de troca catiônica.

Comparando os gráficos referentes ao manejo tradicional e controlado pode-se verificar uma orientação com menos cruzamentos de curvas no manejo controlado, além de se poder visualizar um aumento na salinidade no final do ciclo para os diferentes solos no manejo tradicional, com mais ênfase ao solo arenoso, no qual apenas os níveis referentes a 8 e $9 \mathrm{dS} \mathrm{m}^{-1}$ de salinidade inicial não mostraram alterações.

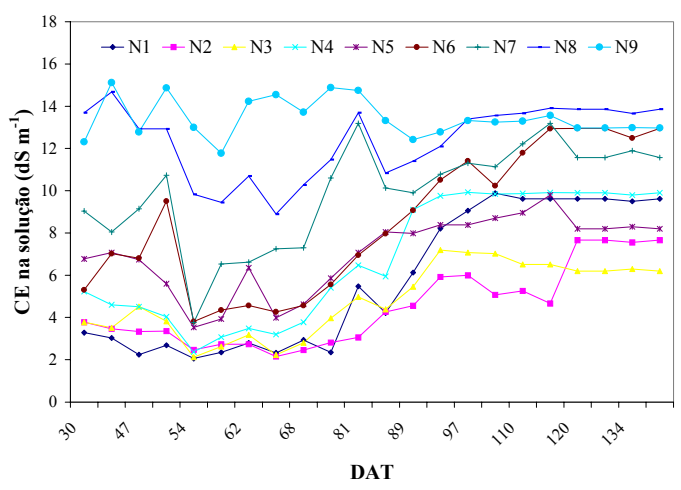

(A)

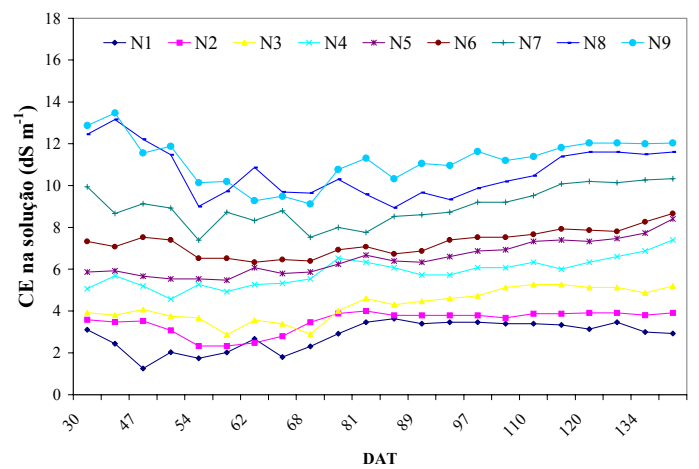

(C)

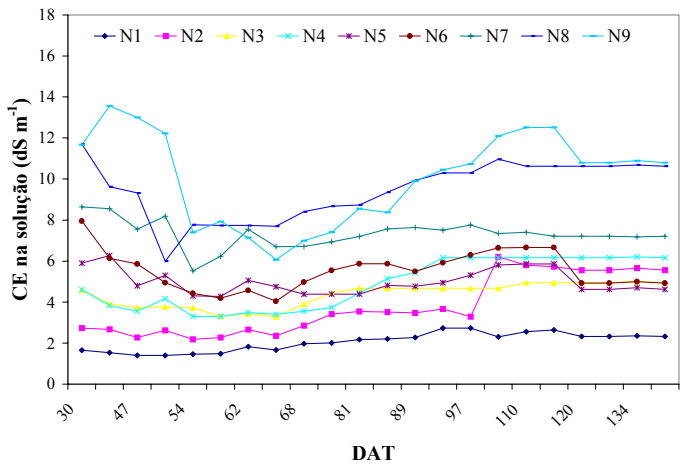

(B)

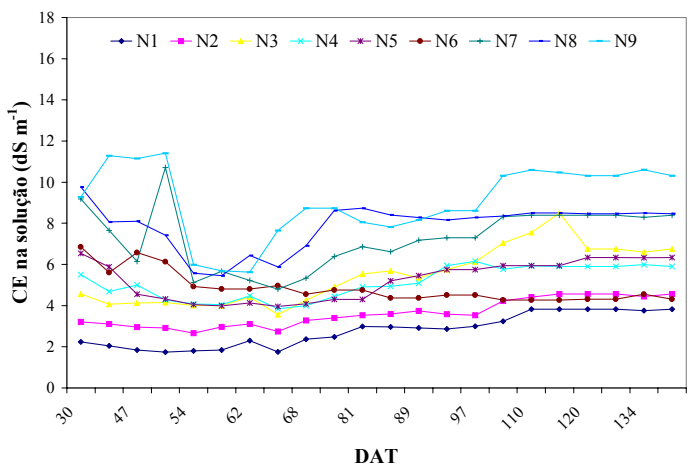

(D)

Figura 26 - Valores de condutividade elétrica na solução do solo ao longo do ciclo da cultura para: (A) solo franco-arenoso com manejo de fertirrigação tradicional, (B) solo franco-argiloso com manejo de fertirrigação tradicional, (C) solo franco-arenoso com manejo de fertirrigação controlado, (D) solo franco-argiloso com manejo de fertirrigação controlado 
Esse fato permite inferir que a salinidade no solo pode ser controlada a partir do conhecimento da salinidade do solo ao longo do ciclo da cultura e da correção das quantidades aplicadas de fertilizantes. Durante o ciclo foram realizadas oito correções nas quantidades de fertilizantes aplicadas no solo franco-arenoso contra quatro no solo franco-argiloso. Em ciclos sucessivos, pequenos aumentos na salinidade do solo como foi observado no final deste ciclo podem acarretar maiores prejuízos.

As concentrações parciais dos nutrientes também foram determinadas ao longo do ciclo da cultura e não diferiram do comportamento da condutividade elétrica; mesmo assim permitiu corrigir em duas oportunidades as quantidades de cálcio, magnésio e nitrato aplicados via fertirrigação.

Outro aspecto de grande valia é a constância dos valores das variáveis determinadas em leituras sucessivas ao longo do tempo. Isso reforça a proposição de monitorar a concentração total ou parcial de íons ao longo do tempo em locais fixos.

\subsubsection{Distribuição dos sais nos solos}

Diversos estudos têm demonstrado que o acúmulo de sais no solo na irrigação por gotejamento se dá na periferia do bulbo e na camada superficial do solo (Bresler, 1975; Medeiros, 1998; Blanco, 1999). Entretanto, estudos realizados em vasos para determinação da tolerância das culturas à salinidade, associados à irrigação localizada, geralmente não levam em consideração a distribuição de sais no solo ao final do período de cultivo.

Nos experimentos em vasos, a interferência causada pelas paredes do recipiente na distribuição de água e sais pode resultar em uma situação que favoreça o aumento ou a redução da concentração de sais na região radicular, podendo interferir na tolerância da cultura. Nestes casos é utilizado como sistema de irrigação o gotejamento, o qual, proporciona a formação de um bulbo molhado com concentrações salinas mais elevadas em sua periferia e reduzidas próximo aos emissores, como afirma Or (2000). Com isso, é importante que em ensaios conduzidos em vasos, a distribuição espacial da 
condutividade elétrica seja avaliada para que se obtenha um resultado mais preciso das condições às quais a cultura foi submetida.

Como os dados analisados no presente trabalho apresentaram tendências e ajustes completamente opostos, para o fator solo, desenvolveu-se esse estudo a partir de determinações da condutividade elétrica 1:2, em amostras pontuais, com camadas de $10 \mathrm{~cm}$, construindo-se isolinhas de salinidade, para vasos com salinidade inicial do solo de $5 \mathrm{dS} \mathrm{m} \mathrm{m}^{-1}$ e ambos os solos, com a finalidade de auxiliar na compreensão desses resultados.

Como se observa nas Figuras 27 e 28, a salinidade do solo mostrou uma distribuição espacial desuniforme, em corte transversal, para os solos franco-arenoso e franco-argiloso, respectivamente, sendo os resultados de salinidade determinados coerentes com a salinidade intermediária de $5 \mathrm{dS} \mathrm{m}^{-1}$. A salinidade média na camada 0 à $20 \mathrm{~cm}$, onde se concentra a maior parte do sistema radicular, foi superior para o solo franco-arenoso. Enquanto que a maioria dos sais no solo franco-argiloso localizou-se nas camadas mais inferiores e nas extremidades do vaso.

Com isso, verifica-se que a ocorrência do arraste dos sais para a periferia do bulbo molhado foi superior para o solo franco-argiloso, em relação ao solo franco arenoso, possivelmente em função do formato do bulbo, que para o solo franco-arenoso corresponde metaforicamente a uma cenoura e para o solo franco-argiloso a uma cebola. Assim sendo, o fluxo de sais no solo acompanhou o caminhamento da frente de molhamento, concordando com a teoria apresentada por Bresler (1975) e a menor presença de sais na superfície do solo franco-argiloso deve-se à alta freqüência de irrigação e à umidade constante nessa interface.

Observou-se visualmente que, o desenvolvimento do sistema radicular no solo franco-arenoso foi superior ao solo franco-argiloso. No solo franco-argiloso observou-se que grande parte das raízes se localizava próxima à região do gotejador, e como foi nessa região que as plantas absorveram a quase totalidade da água e nutrientes necessários para seu desenvolvimento, em condições mais salinas as plantas seriam beneficiadas em relação à diminuição nos rendimentos ocasionada pela redução no potencial osmótico. Além de que, o incremento na salinidade possivelmente funcionou 
como estoque de nutrientes, acumulados nas camadas adjacentes, os quais movimentavam-se para o sistema radicular por difusão.

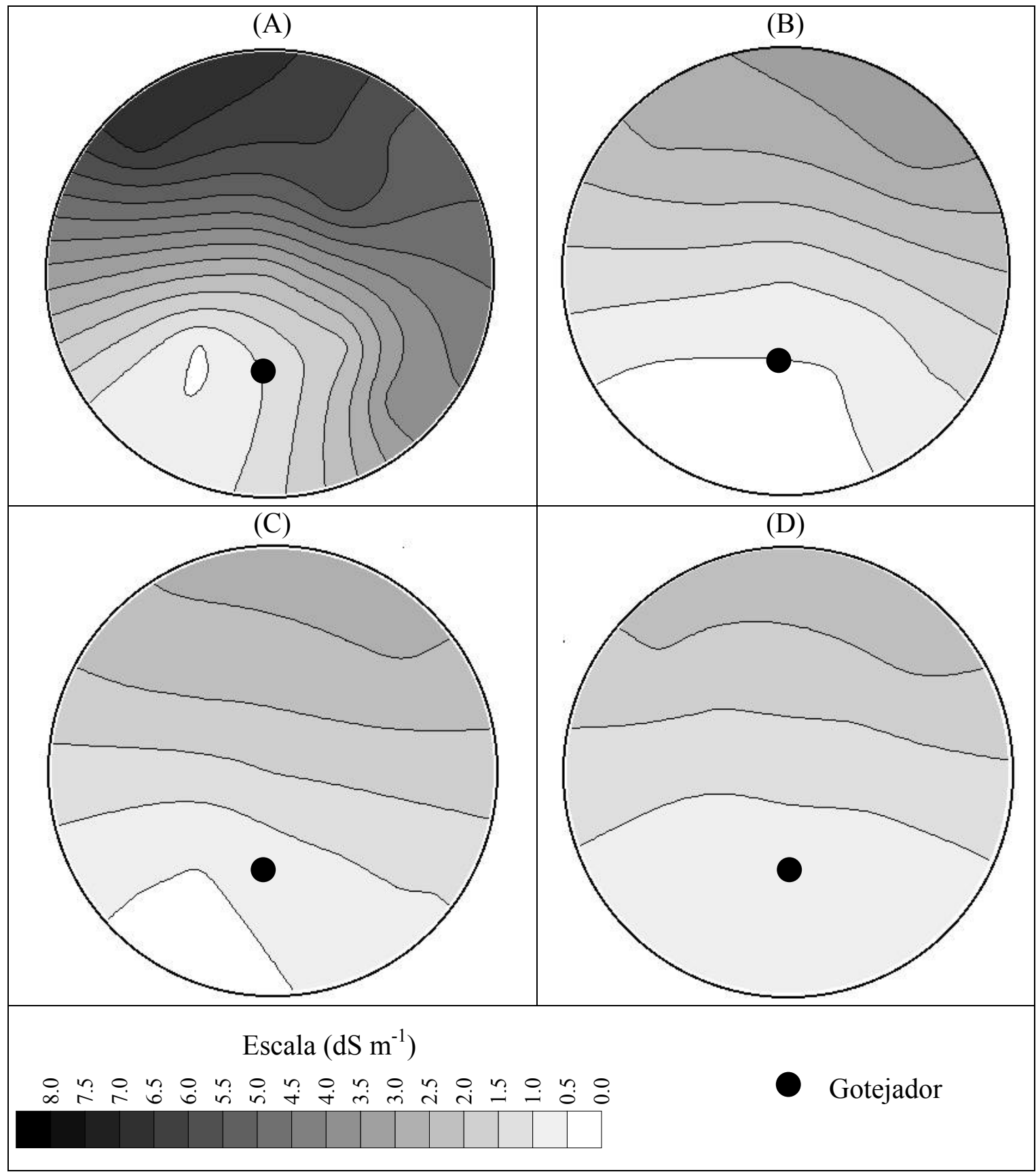

Figura 27 - Distribuição espacial da condutividade elétrica nos vasos com salinidade inicial de $5 \mathrm{dS} \mathrm{m}^{-1}$ no solo franco-arenoso nas profundidades de (A) 0-10, (B) 10-20, (C) 20-30 e (D) 30-40 cm 


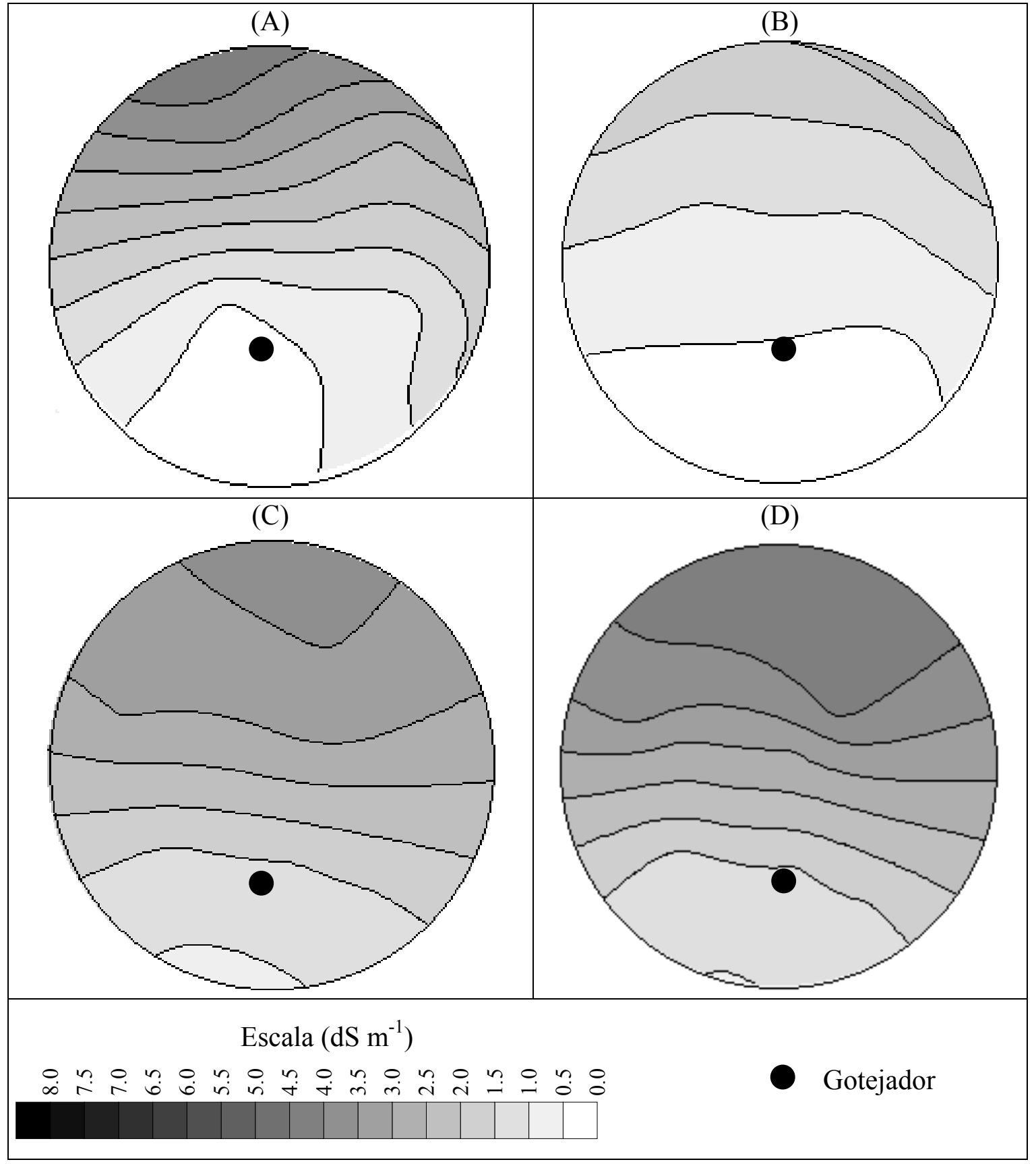

Figura 28 - Distribuição espacial da condutividade elétrica nos vasos com salinidade inicial de $5 \mathrm{dS} \mathrm{m} \mathrm{m}^{-1}$ no solo franco-argiloso nas profundidades de (A) $0-10$, (B) $10-20$, (C) $20-30 \mathrm{e}$ (D) $30-40 \mathrm{~cm}$ 


\title{
4.2.4 Comparação entre medidas de condutividade elétrica e concentração iônica determinadas nas soluções extraídas pela cápsula porosa e no extrato de saturação
}

\begin{abstract}
A Figura 29 ilustra uma regressão linear entre os valores de condutividade elétrica medidos no extrato de saturação e estimados a partir da condutividade elétrica da solução do solo com correção para umidade da pasta saturada.
\end{abstract} Nota-se que as determinações da condutividade elétrica na solução obtidas via extrator podem ser utilizadas para estimar os valores medidos no extrato saturado, quando corrigida para a umidade de saturação. A correlação desses valores com os medidos no extrato de saturação mostram o coeficiente de determinação $\left(\mathrm{R}^{2}\right)$ significativo e igual a 0,96, e o índice de concordância de Willmott em relação a reta 1:1 igual a 0,99.

Isto demonstra que os resultados encontrados podem ser considerados satisfatórios, caso seja levado em consideração que a determinação da umidade do solo foi realizada utilizando-se tensiômetros, os quais implicam em medida indireta e de menor precisão. Os valores de condutividade elétrica obtidos com os extratores de cápsulas porosas e corrigidos para a umidade da pasta subestimaram os medidos no extrato da pasta saturada em torno de apenas 3\%. Pelo teste de Komolgorov-Smirnov os métodos não diferem entre si com um nível de significância de 5\% e o coeficiente D gerado pelo método apresentou um valor calculado de 0,10 .

Assim sendo, pode-se afirmar que, em relação à condutividade elétrica, o método proposto, ou seja, o da cápsula porosa, pode ser utilizado com precisão e exatidão satisfatória na determinação e monitoramento da salinidade do solo. 


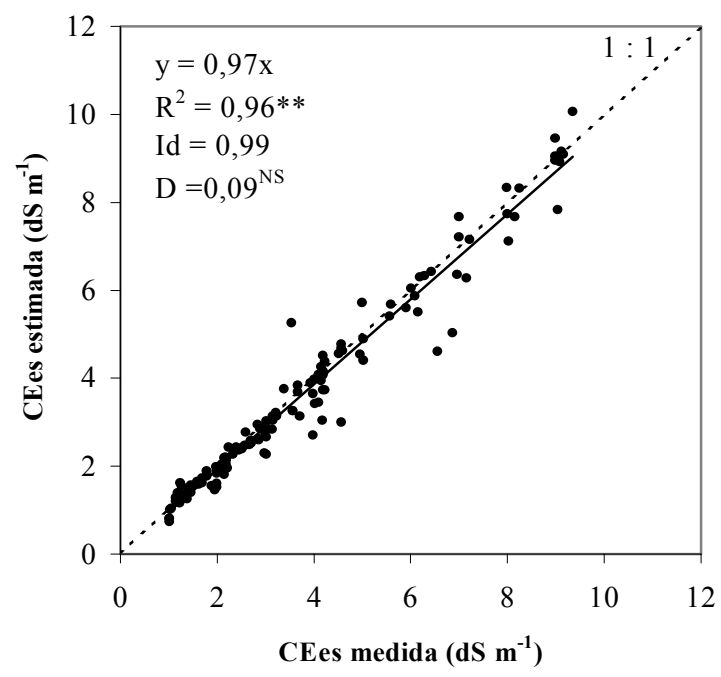

Figura 29 - Relação entre os valores de condutividade elétrica do extrato de saturação, medido e estimado a partir da condutividade elétrica da solução obtida com extrator de cápsula com correção em função da umidade para ambos os solos utilizados no experimentoII

Na Figura 30 observa-se a comparação entre as concentrações iônicas determinadas na solução do solo e corrigidas para umidade de saturação e as determinadas no extrato de saturação. Os diagramas (A), (B), (C), (D), (E) e (F) demonstrados na Figura 30 são relativos aos nutrientes potássio, nitrato, cálcio, magnésio, enxofre e fósforo, respectivamente. As determinações de potássio nas amostras retiradas pelas duas metodologias apresentaram forte correlação com $\mathrm{R}^{2}$ significativo e igual a 0,95 , ou seja, com uma precisão de $95 \%$ pode-se afirmar que a concentração de potássio medida na solução do solo e corrigida para umidade de saturação superestimou em média o medido no extrato saturado em $4 \%$. O índice de concordância de Willmott de 0,99 mostra que a metodologia proposta, ou seja, da solução do solo, tem uma boa exatidão em relação a metodologia padrão, ou seja , a determinação no extrato de saturação. O D calculado de Kolmogorov-Smirnov de 0,07 foi inferior ao tabelado, representando assim que os métodos não diferiram entre si. Esse resultado vem a corroborar com o trabalho realizado por Silva et al. (2000b), em cultivo de tomates, o qual sugere que a concentração de potássio pode ser determinada pelo uso de cápsulas porosas. 


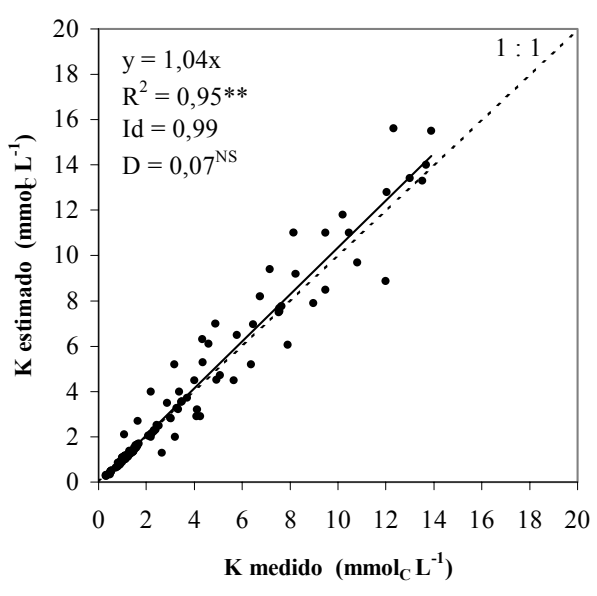

(A)

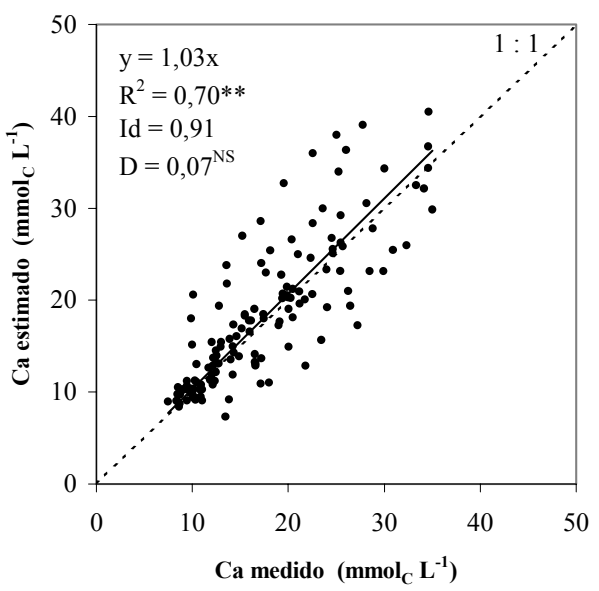

(C)

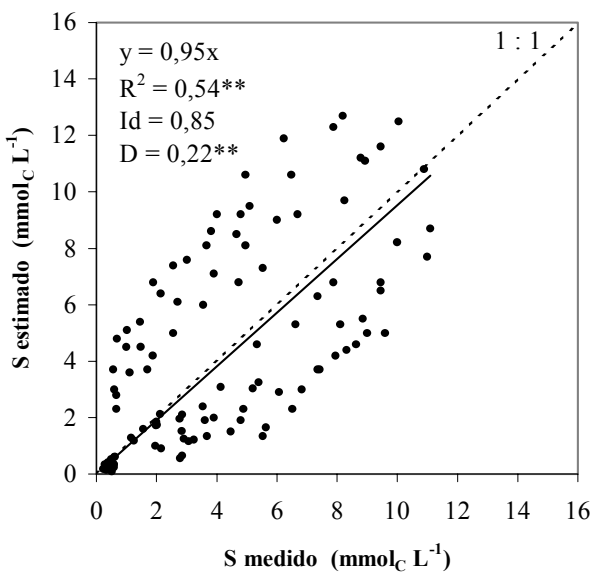

(E)

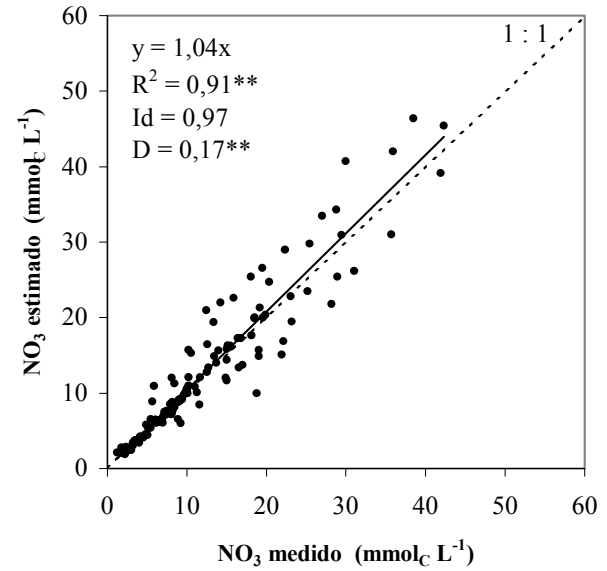

(B)

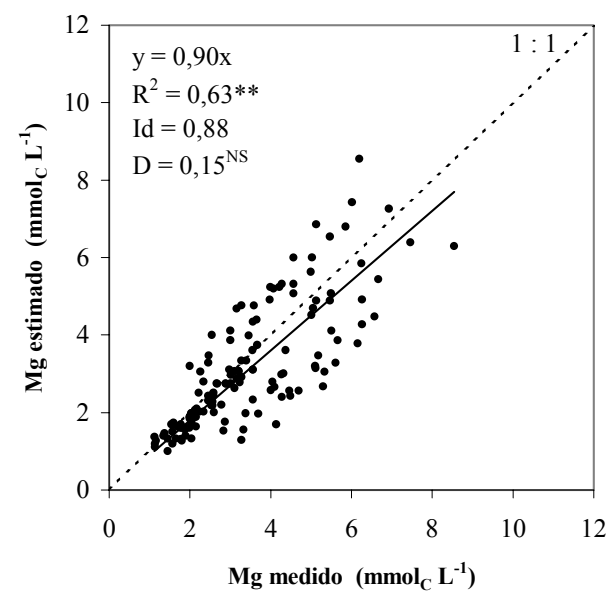

(D)

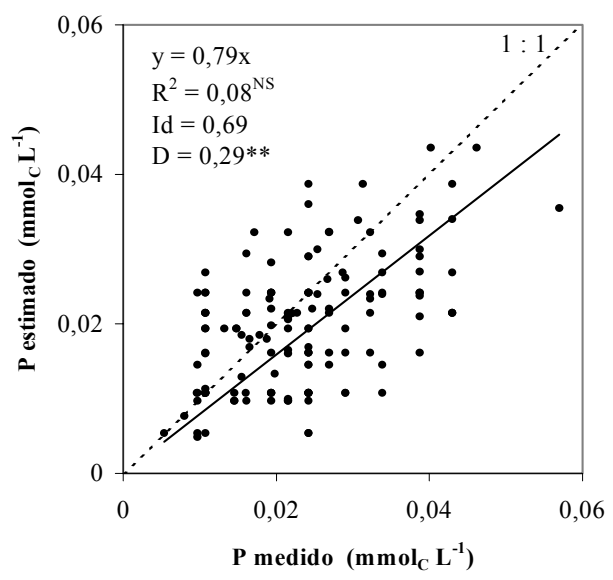

(F)

Figura 30 - Relação entre os valores de: (A) K, (B) $\mathrm{NO}_{3}$, (C) $\mathrm{Ca}$, (D) $\mathrm{Mg}$, (E) S e (F) P no extrato de saturação, medido e estimado a partir das concentrações correspondentes na solução obtida com extrator de cápsula com correção em função da umidade para ambos os solos utilizados no experimento II 
A regressão (B) da Figura 30 se refere a comparação entre a determinação do nitrato na solução do solo com correção para umidade de saturação e no extrato de saturação. Os valores de $\mathrm{R}^{2}$ de 0,91 e índice de concordância de 0,97 confirmam boa precisão e exatidão, resultados semelhantes são apresentados por Silva et al. (2000b). O coeficiente angular da regressão retrata que o método proposto superestima o padrão em 4\%. Entretanto o valor de D foi significativo a um nível de significância de 5\% e sugere que o método necessita de ajuste prévio para ser comparado ao padrão.

As concentrações de cálcio e magnésio na solução do solo quando comparadas em função da metodologia proposta e padrão apresentam uma correlação apenas razoável se comparado aos demais íons supra citados, com $\mathrm{R}^{2}$ de 0,70 e 0,63, respectivamente (Figura $30 \mathrm{C}$ e D). As determinações na solução do solo com correção em função da umidade superestimaram em 3\% e subestimaram em 10\% os valores determinados no extrato de saturação para os nutrientes cálcio e magnésio. O teste de Kolmogorov-Smirnov retrata que ambos os métodos, ou seja, o proposto e o padrão não diferem entre si significativamente a $5 \%$ de probabilidade.

Nos gráficos (E) e (F) da Figura 30, são comparados os nutrientes enxofre e fósforo determinados na solução do solo com correção de umidade e no extrato de saturação. Para os dois íons, as metodologias empregadas são significativamente diferentes pelo teste de Kolmogorov-Smirnov a um nível de 5\% de probabilidade.

A fraca correlação e a ausência de correlação representadas pelo coeficiente de determinação, os quais apresentam valores de 0,54 e 0,08 para o enxofre e fósforo, respectivamente e o baixo índice de concordância de Willmott de 0,85 e 0,69, permite afirmar que a metodologia que propõe a determinação desses íons após extração pela cápsula cerâmica e correção de umidade para saturação não é capaz de estimar com exatidão e precisão a concentração no extrato de saturação. A dispersão dos pontos no diagrama correspondente as concentrações de fósforo pode ser atribuída a mobilidade desse íon, ou seja, da fixação desse no solo. Já a dispersão em relação ao enxofre pode ter relação com reações químicas promotoras de precipitação na forma de sais sulfatos. 


\subsubsection{Relações de umidade dos solos}

Na Figura 31 pode-se observar o potencial mátrico médio do solo ao longo do ciclo de pimentão para os solos utilizados. De acordo com os resultados obtidos pode-se afirmar que o controle de umidade no solo a partir das leituras tensiométricas e curvas características de umidade no solo foi eficiente ao longo de todo o ciclo da cultura.

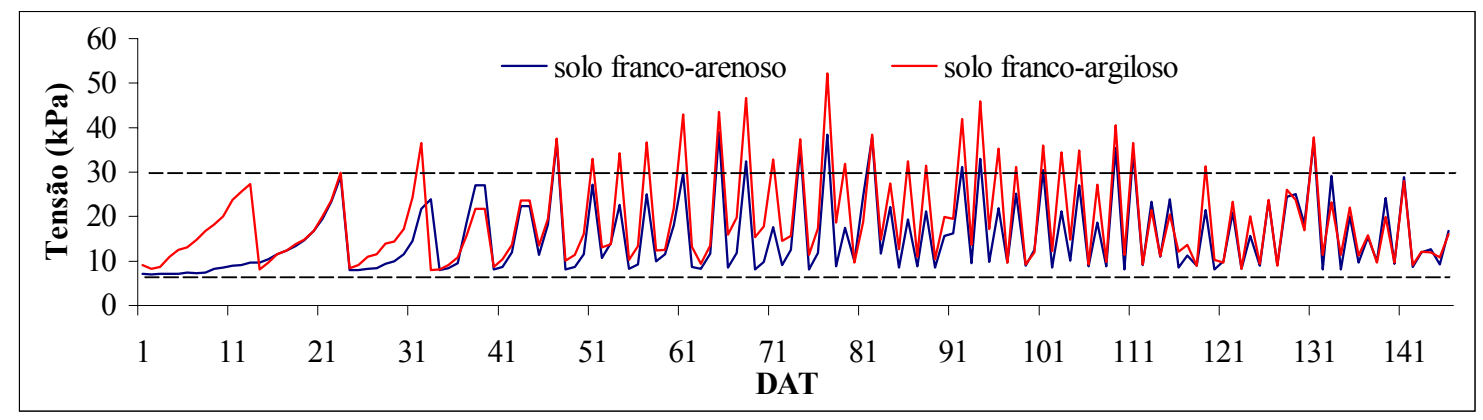

Figura 31 - Potencial mátrico médio para os diferentes tratamentos ao longo do ciclo de pimentão

Determinou-se a porosidade média livre de água para os dois solos afim de observar se a aeração dos solos estariam comprometendo o crescimento e desenvolvimento das plantas (Figura 32). A porosidade livre de água foi calculada com base na diferença entre a umidade atual e a de saturação dos solos. Os resultados apresentados mostram que a porcentagem de poros livres de água, tanto para o solo franco-arenoso quanto para o solo franco-argiloso, foi adequada para o fornecimento de oxigênio necessário ao processo respiratório do sistema radicular. Segundo Cruciani (1987), para maioria das culturas o valor mínimo necessário de porosidade livre está entre 10 e $20 \%$.

Dessa forma, o diferente desenvolvimento entre o sistema radicular das plantas para as diferentes texturas de solo possivelmente deve-se a outra forma de impedimento. Ou ainda, a proximidade das raízes da região do gotejador pode sugerir que em virtude da alta freqüência e da capacidade de retenção da água pelo solo francoargiloso não tornou-se necessário um maior aprofundamento do sistema radicular. 


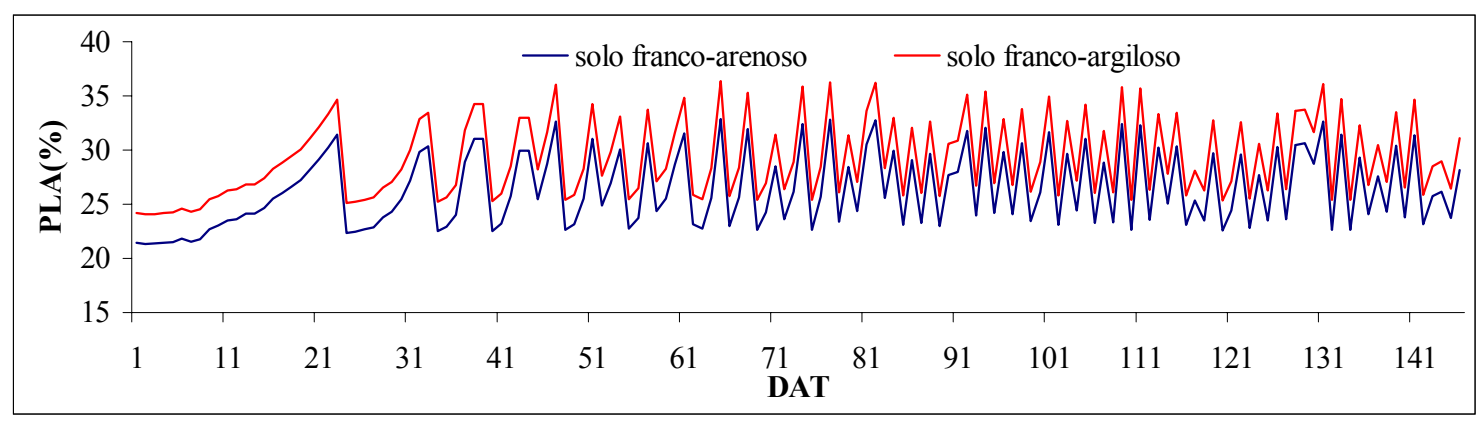

Figura 32 - Porosidade média do solo livre de água (PLA) para os diferentes tratamentos ao longo do ciclo de pimentão

\subsubsection{Características vegetativas}

\subsubsection{Massa de folhas, caule e parte aérea}

A massa seca representa fisiologicamente o crescimento da planta ao longo do ciclo, com forte correlação em relação a altura de plantas e pode ainda representar a fotossíntese líquida. A massa, verde por sua vez, possibilita interpretar o suprimento hídrico da planta. Na Tabela 7 está apresentado um resumo da análise de variância para as variáveis massa de folha, caule e parte aérea, seca e verde. Pelo teste de F verificou-se que todas as variáveis diferiram significativamente a $1 \%$ em função da salinidade do solo. Da mesma forma, o fator solo interferiu nas variáveis, assim como a interação entre esse fatores. Dessa forma, realizou-se o estudo em separado para os diferentes tipos de solo.

No solo franco-arenoso (Tabela 8) a massa seca da folha foi afetada significativamente pela salinidade inicial, pelo manejo da fertirrigação e pela interação desses fatores. A massa seca do caule diferiu significativamente em função da salinidade, entretanto não houve efeito significativo da manejo de fertirrigação. O efeito combinado dos fatores salinidade e manejo também foi verificado. A massa seca da parte aérea diferiu em função da salinidade, do manejo e da interação entre eles.

Medeiros (1998) também encontrou diferença significativa de 1\% pelo teste de F para massa seca em função da salinidade, para o híbrido de pimentão Luiz. 
Tabela 7. Resumo da análise de variância para massa de folhas, massa de caule e massa da parte aérea, seca e verde, em função de níveis de salinidade, para diferentes tipos de solo e manejo

\begin{tabular}{ccccccc}
\hline \multirow{2}{*}{$\begin{array}{c}\text { Causa da } \\
\text { Variação }\end{array}$} & MSF & MSC & MSPA & MVF & MVC & MVPA \\
\hline Tratamentos: & & & & & \\
Blocos & 2,33 & 0,87 & 1,49 & 2,55 & $3,17 *$ & $4,02 * *$ \\
Salinidade (N) & $6,04 * *$ & $4,13^{* *}$ & $5,85^{* *}$ & $7,03 * *$ & $6,62^{* *}$ & $6,89 * *$ \\
Solo (S) & $59,99^{* *}$ & $86,14^{* *}$ & $98,11^{* *}$ & $69,85^{* *}$ & $127,8^{* *}$ & $136,97 * *$ \\
Manejo (M) & $18,58^{* *}$ & 1,39 & 2,73 & $9,18^{* *}$ & 0,01 & 3,30 \\
Interações: & & & & & & \\
N x S & $22,66^{* *}$ & $21,21^{* *}$ & $27,75^{* *}$ & $12,22 * *$ & $8,76^{* *}$ & $14,33^{* *}$ \\
N x M & 1,29 & $3,75^{* *}$ & $2,41 *$ & 1,42 & 1,45 & 1,05 \\
S x M & $4,89 *$ & 0,01 & 1,33 & 1,95 & 0,26 & 0,33 \\
N x S x M & 1,61 & $6,15^{* *}$ & $3,36^{* *}$ & 1,86 & $3,60 * *$ & $2,51 *$ \\
\hline
\end{tabular}

** Significativo ao nível de $1 \%$ de probabilidade pelo teste $\mathrm{F}$

* Significativo ao nível de $5 \%$ de probabilidade pelo teste $\mathrm{F}$

A salinidade do solo franco-arenoso influenciou significativamente a massa verde das folhas e da parte aérea, enquanto que o manejo da fertirrigação teve efeito apenas para a massa verde das folhas, ambas ao nível de 1\% de significância.

Tabela 8. Resumo da análise de variância para massa de folhas, massa de caule e massa da parte aérea, seca e verde, em função de níveis de salinidade e manejo da fertirrigação para o solo franco-arenoso

\begin{tabular}{|c|c|c|c|c|c|c|}
\hline \multirow{2}{*}{$\begin{array}{l}\text { Causa da } \\
\text { Variação }\end{array}$} & \multicolumn{6}{|c|}{ Estatística F } \\
\hline & MSF & $\mathrm{MSC}$ & MSPA & MVF & MVC & MVPA \\
\hline \multicolumn{7}{|l|}{ Tratamentos: } \\
\hline Blocos & $3,66^{*}$ & $2,82 *$ & $4,78 * *$ & $3,56^{*}$ & $3,73^{*}$ & $4,98 * *$ \\
\hline Salinidade (N) & $15,50 * *$ & $10,54 * *$ & $16,48 * *$ & $6,89 * *$ & 2,01 & $3,21 * *$ \\
\hline Manejo (M) & $30,18^{* *}$ & 0,956 & $5,66^{*}$ & $12,60 * *$ & 0,15 & 2,81 \\
\hline \multicolumn{7}{|l|}{ Interações: } \\
\hline $\mathrm{N} \times \mathrm{M}$ & 1,86 & $4,87 * *$ & $2,82 *$ & 2,01 & $2,24 *$ & 1,68 \\
\hline
\end{tabular}

A variável massa seca mostrou uma tendência de decréscimo com o incremento da salinidade no solo franco-arenoso, para folha, caule e parte aérea. Para 
folha e parte aérea o ajuste foi linear com queda de 3,61 a 7,01, respectivamente. Enquanto que para o caule o ajuste foi quadrático com o valor máximo para salinidade de aproximadamente $4 \mathrm{dS} \mathrm{m}^{-1}$ (Figura 33).

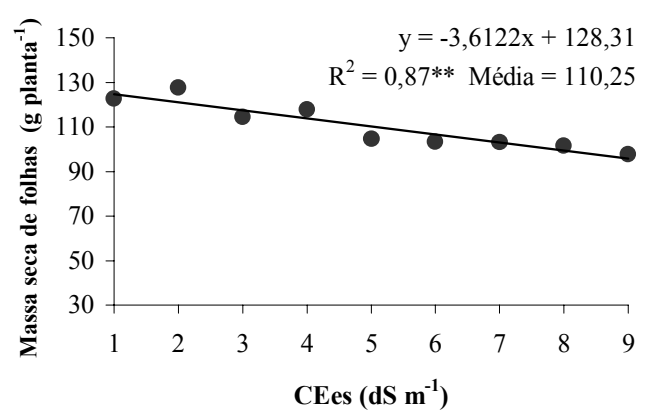

(A)

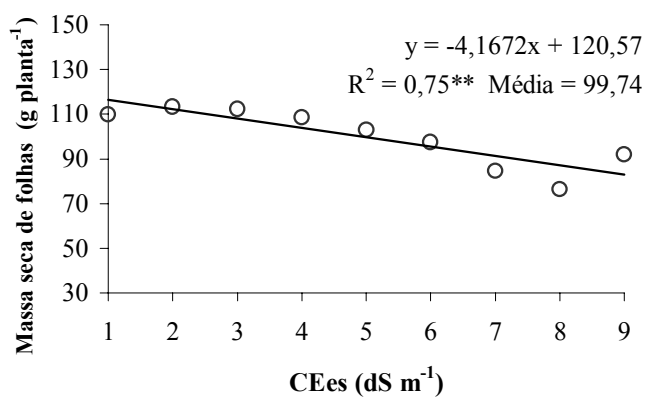

(B)

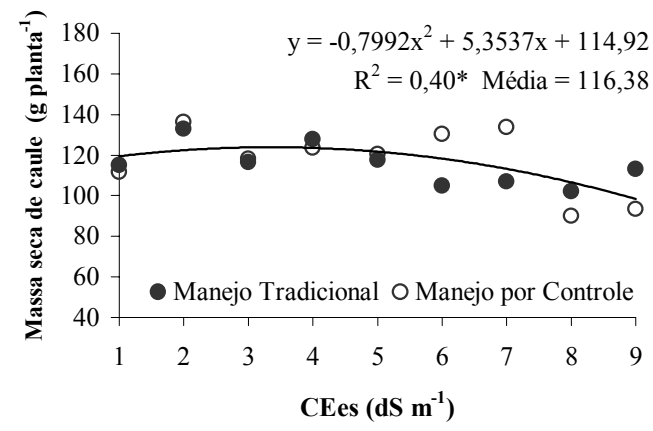

(C)

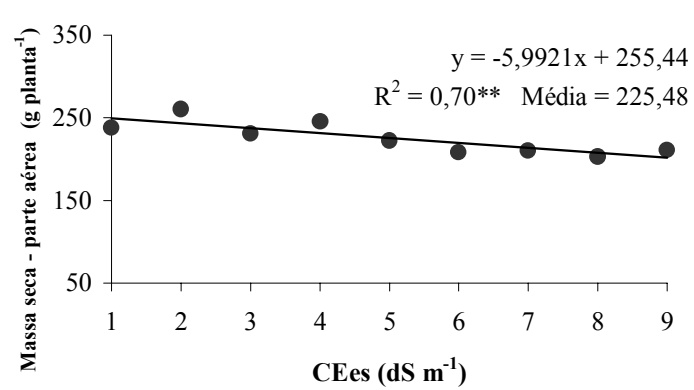

(D)

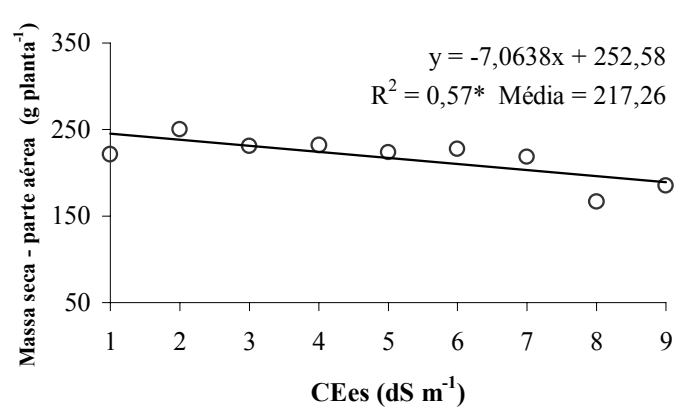

(E)

Figura 33 - Diagrama de dispersão e equação de ajuste para o solo franco-arenoso entre: (A) massa seca de folhas com manejo tradicional da fertirrigação, (B) massa seca de folhas com manejo controlado da fertirrigação, (C) massa seca do caule para ambos os manejos de fertirrigação, (D) massa seca da parte aérea com manejo tradicional da fertirrigação e (E) massa seca da parte aérea com manejo controlado da fertirrigação e a salinidade inicial do solo 
Na Figura 34 são apresentados os diagramas de dispersão das variáveis massa fresca das folhas, caule e parte aérea em função da salinidade inicial do solo franco-arenoso. Observa-se nos gráficos (A) e (B) um ajuste linear decrescente para variável massa fresca de folhas. $\mathrm{O}^{2}$ igual à 0,41 e 0,63 para os manejos da fertirrigação tradicional e controlado, respectivamente, ilustra a dispersão dos dados em relação a reta de ajuste.

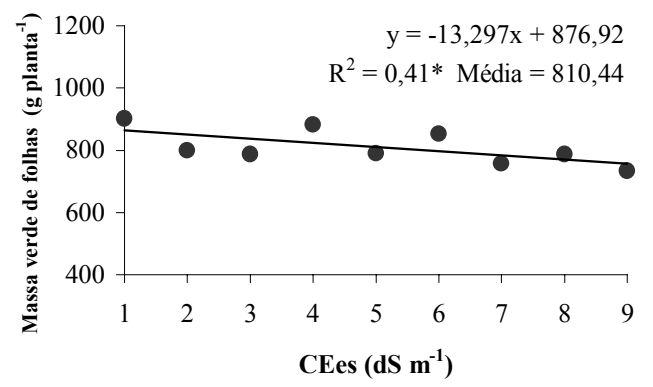

(A)

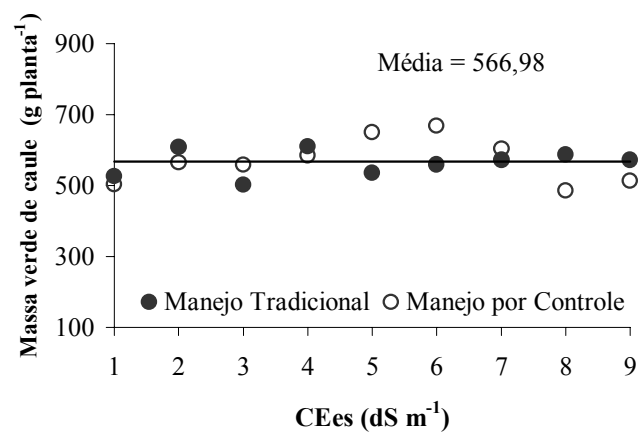

(C)

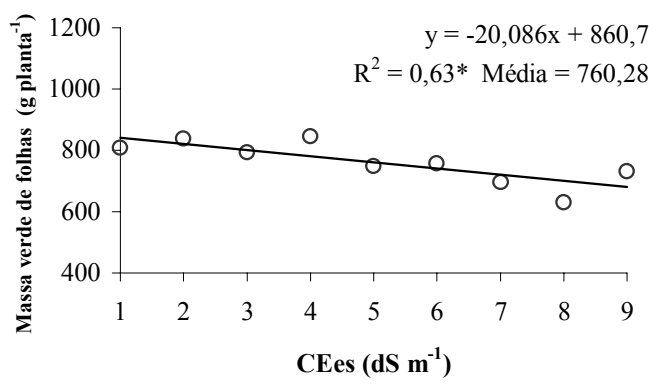

(B)

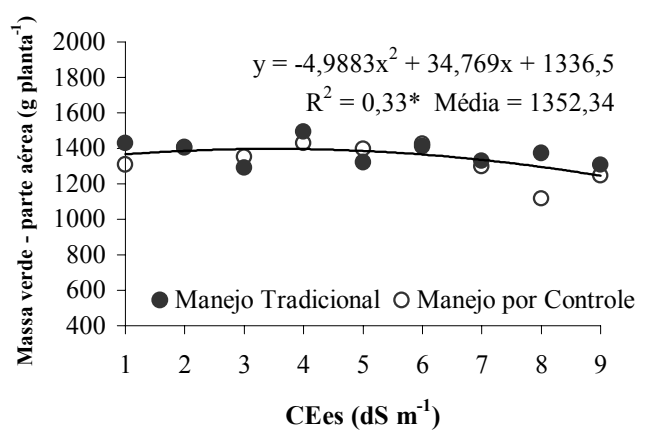

(D)

Figura 34 - Diagrama de dispersão e equação de ajuste para o solo franco-arenoso entre: (A) massa verde de folhas com manejo tradicional da fertirrigação, (B) massa verde de folhas com manejo controlado da fertirrigação, (C) massa verde do caule para ambos os manejos de fertirrigação e (D) massa verde da parte aérea para ambos os manejos de fertirrigação e a salinidade inicial do solo

As variáveis massa fresca do caule e da parte aérea não apresentam uma tendência definida para ambos os manejos da fertirrigação e para o solo franco-arenoso. A média para essas variáveis são respectivamente 566,98 g e 1352,43 g.

A Tabela 9 refere-se ao resumo da análise de variância para o solo franco-argiloso. Nela pode-se verificar que as variáveis relacionadas a massa seca e 
verde das folhas, caule e parte aérea foram influenciadas significativamente pelos níveis de salinidade inicial do solo. $\mathrm{O}$ fator manejo da fertirrigação não foi significativo para as mesmas variáveis.

Tabela 9. Resumo da análise de variância para massa de folhas, massa de caule e massa da parte aérea, seca e verde, em função de níveis de salinidade e manejo da fertirrigação para o solo franco-argiloso

\begin{tabular}{|c|c|c|c|c|c|c|}
\hline \multirow{2}{*}{$\begin{array}{l}\text { Causa da } \\
\text { Variação }\end{array}$} & \multicolumn{6}{|c|}{ Estatística F } \\
\hline & MSF & MSC & MSPA & MVF & MVC & MVPA \\
\hline \multicolumn{7}{|l|}{ Tratamentos: } \\
\hline Blocos & 2,06 & $4,75^{* *}$ & $2,95^{*}$ & 1,90 & $3,69^{*}$ & $3,58^{*}$ \\
\hline Salinidade $(\mathrm{N})$ & $14,88^{* *}$ & $18,81 * *$ & $20,71^{* *}$ & $12,18^{* *}$ & $22,95 * *$ & $22,21 * *$ \\
\hline Manejo (M) & 1,84 & 0,67 & 0,12 & 1,17 & 0,14 & 0,95 \\
\hline \multicolumn{7}{|l|}{ Interações: } \\
\hline $\mathrm{N} \times \mathrm{M}$ & 1,33 & $6,62 * *$ & $3,57 * *$ & 1,50 & $3,90^{* *}$ & $2,29 *$ \\
\hline
\end{tabular}

Para o solo franco-argiloso o ajuste predominante para todas as variáveis foi o linear crescente. Todavia, os valores dos coeficientes de determinação $\left(R^{2}\right)$ que variaram entre 0,20 e 0,63 , apesar de significativos, mostram a fraca correlação entre as variáveis e a salinidade do solo; pode-se também observar a dispersão dos pontos em relação a reta de ajuste (Figura 35 ).

Os valores obtidos para as variáveis massa de folhas, caule e parte aérea, seca e verde no presente experimento são considerados altos se comparados aos resultados apresentados por Villas Bôas (2001) utilizando o mesmo híbrido, o qual obteve um valor máximo para peso seco da parte aérea de $150,4 \mathrm{~g}$ por planta. No presente experimente obtiveram-se valores superiores a $250,0 \mathrm{~g}$ por planta, para o tratamento não salinizado, ou seja, com $1 \mathrm{dS} \mathrm{m}^{-1}$ de salinidade inicial. 


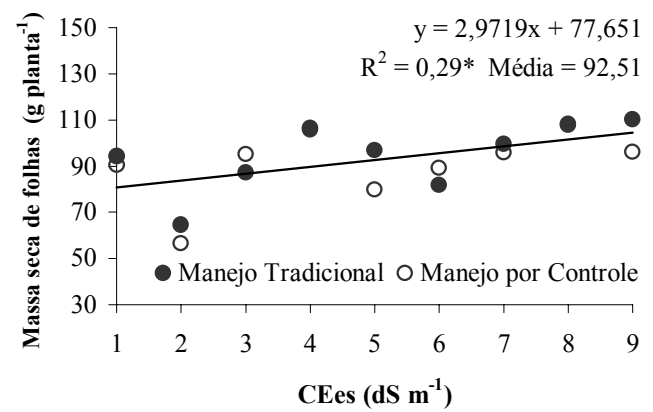

(A)

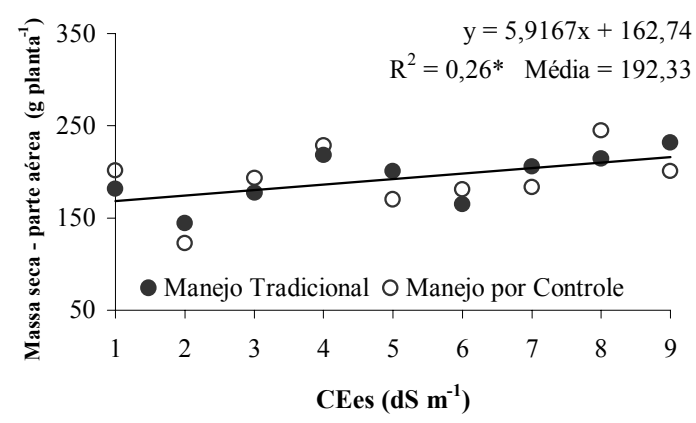

(C)

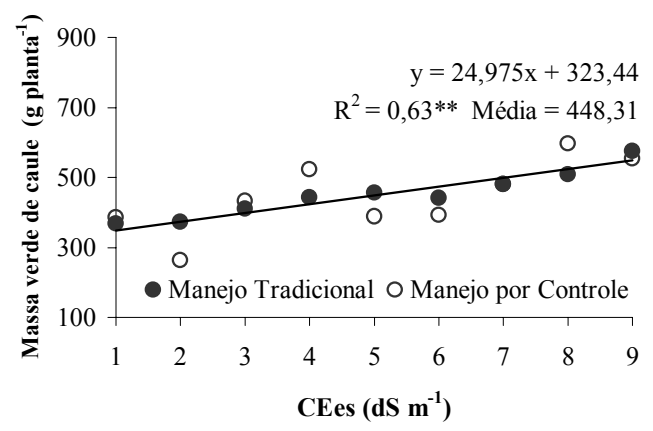

(E)

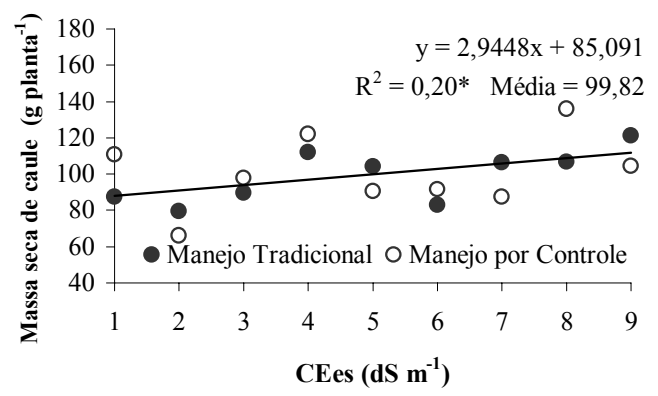

(B)

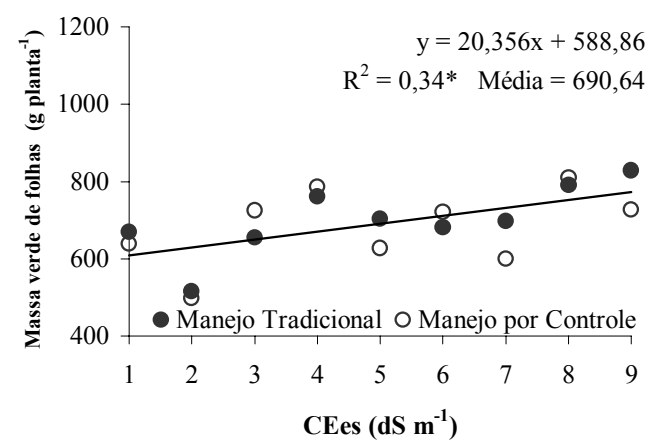

(D)

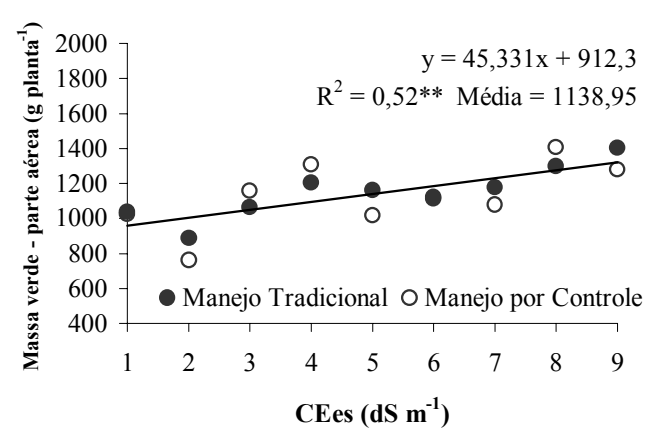

(F)

Figura 35 - Diagrama de dispersão e equação de ajuste para o solo franco-argiloso entre: (A) massa seca de folhas, (B) massa seca de caule, (C) massa seca da parte aérea, (D) massa verde de folhas, (E) massa verde do caule e (F) massa verde da parte aérea, para os ambos manejos e a salinidade inicial do solo

\subsubsection{Altura de plantas}

A altura das plantas foi afetada significativamente pela salinidade inicial e pelo tipo de solo, excetuando-se a análise realizada aos 70 DAT que mostrou diferença significativa para manejo da fertirrigação. A maioria das interações foi significativa 
como pode-se observar na Tabela 10, assim sendo, foi realizada análises em relação a cada solo.

Tabela 10. Resumo da análise de variância para altura de planta em função de níveis de salinidade, para diferentes tipos de solo e manejo

\begin{tabular}{ccccc}
\hline \multirow{2}{*}{$\begin{array}{c}\text { Causa da } \\
\text { Variação }\end{array}$} & \multicolumn{4}{c}{ Estatística F } \\
& Altura de Planta \\
& 30 dias & 70 dias & 130 dias & 150 dias \\
\hline Tratamentos: & & & \\
Blocos & $5,90^{* *}$ & 2,46 & $3,847^{*}$ & 0,88 \\
Salinidade (N) & $3,12^{* *}$ & $8,90^{* *}$ & $2,23^{*}$ & $3,74^{* *}$ \\
Solo (S) & $26,40^{* *}$ & 0,54 & $40,44^{* *}$ & $11,39^{* *}$ \\
Manejo (M) & 2,36 & $10,41^{* *}$ & 2,18 & 0,04 \\
Interações: & & & & \\
N x S & $8,83^{* *}$ & $33,22^{* *}$ & $2,49^{*}$ & $2,63^{*}$ \\
N x M & 0,62 & $3,58^{* *}$ & $3,47^{* *}$ & $3,55^{* *}$ \\
S x M & 1,41 & $17,16^{* *}$ & $17,70^{* *}$ & $6,34^{*}$ \\
N x S x M & 0,69 & $3,64^{* *}$ & $5,52^{* *}$ & $2,38^{*}$ \\
\hline
\end{tabular}

** Significativo ao nível de $1 \%$ de probabilidade pelo teste $\mathrm{F}$

* Significativo ao nível de $5 \%$ de probabilidade pelo teste $\mathrm{F}$

Na Tabela 11 observa-se que para o solo franco arenoso as análises de variância realizadas com dados até 30 DAT e 70 DAT mostraram diferença significativa causada pela salinidade do solo pelo teste de F a 1\% e aos 150 DAT a altura de planta diferiu significativamente a um nível de $5 \%$. Em relação ao fator manejo da fertirrigação apenas aos 30 DAT ocorreu diferença significativa, assim como houve o efeito combinado entre os fatores nível de salinidade e manejo da fertirrigação.

A diferença nos resultados obtidos no presente experimento contrasta com a diferença dos valores determinados por Medeiros (1998), o mesmo cita que a salinidade do solo não influenciou significativamente na altura de plantas. O híbrido Luiz, utilizado por Medeiros (1998), alcançou valores médios de 161,9 cm de altura aos 165 dias após o transplante. 
Tabela 11. Resumo da análise de variância para altura de planta em função de níveis de salinidade e manejo da fertirrigação para o solo franco-arenoso

\begin{tabular}{|c|c|c|c|c|}
\hline \multirow{2}{*}{$\begin{array}{l}\text { Causa da } \\
\text { Variação }\end{array}$} & \multicolumn{4}{|c|}{$\begin{array}{c}\text { Estatística F } \\
\text { Altura de Planta }\end{array}$} \\
\hline & 30 dias & 70 dias & 130 dias & 150 dias \\
\hline \multicolumn{5}{|l|}{ Tratamentos: } \\
\hline Blocos & $7,13 * *$ & $2,92 *$ & 1,67 & 1,00 \\
\hline Salinidade (N) & $10,27 * *$ & $34,99 * *$ & 1,09 & $2,78^{*}$ \\
\hline Manejo (M) & $5,92 *$ & 0,43 & 2,97 & 2,76 \\
\hline \multicolumn{5}{|l|}{ Interações: } \\
\hline $\mathrm{N} \times \mathrm{M}$ & $7,13 * *$ & 2,92 & 1,67 & 1,00 \\
\hline
\end{tabular}

** Significativo ao nível de $1 \%$ de probabilidade pelo teste $\mathrm{F}$

* Significativo ao nível de $5 \%$ de probabilidade pelo teste $\mathrm{F}$

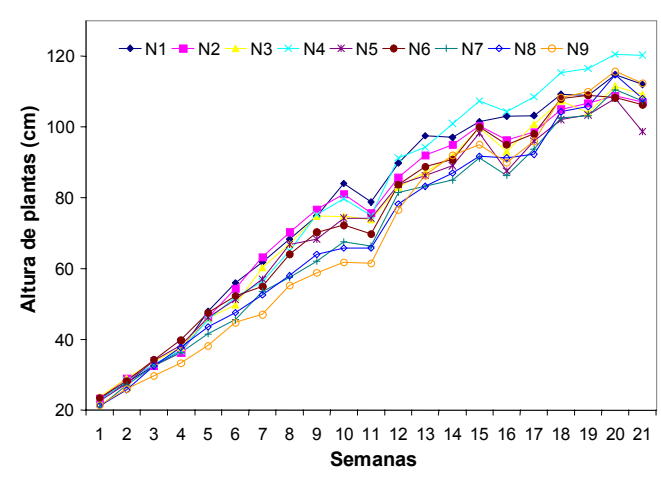

(A)

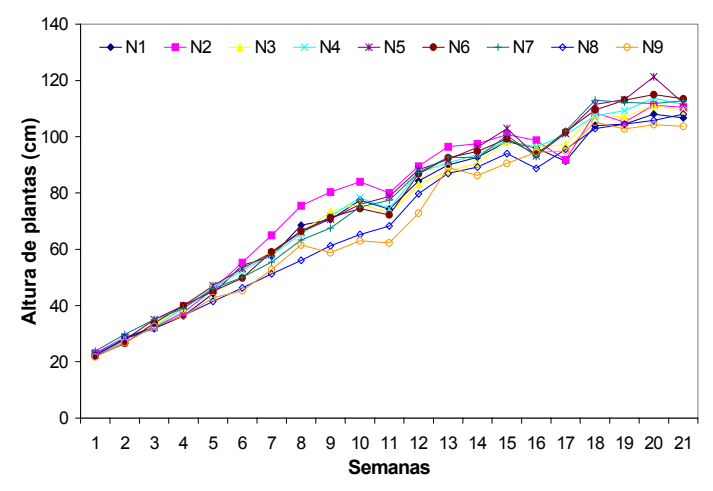

(B)

Figura 36 - Altura de plantas para os diferentes níveis de salinidade: (A) manejo tradicional de fertirrigação e (B) manejo controlado de fertirrigação para o solo franco-arenoso

A Figura 36 ilustra o crescimento das plantas ao longo do ciclo da cultura para os diferentes manejos de fertirrigação, para o solo franco-arenoso. Nota-se que o crescimento para ambos os tratamentos mostrou-se uniforme, com destaque para o período até a sexta semana após o transplantio. Pode-se observar também, em alguns pontos específicos, na décima e na décima sexta semana, por exemplo, um decréscimo na altura média das plantas. Esses decréscimos ocorrem, justamente, nos momentos em que as plantas estavam com um grande carga de frutos e assim os ramos superiores apresentavam altura menor em relação as semanas anteriores. 
As análises de regressão apresentadas nos gráficos (A) e (B) da Figura 37 são referentes a altura de planta para o solo franco-arenoso realizadas aos 30 DAT para o manejo da fertirrigação tradicional e controlado, respectivamente. Em ambos nota-se um ajuste polinomial quadrático, ou seja, a salinidade proporcionou um maior crescimento da planta até um máximo obtido aproximadamente com a salinidade inicial de $5 \mathrm{dS} \mathrm{m}^{-1} \mathrm{e}$ a partir desse ponto ocorre um decréscimo da altura. Entretanto, aos 70 DAT a análise mostra um ajuste linear. Todavia as análises realizadas aos 30 DAT e aos 70 DAT sugerem uma boa correlação entre a altura de planta e a salinidade inicial do solo.

O gráfico (D) da Figura 37 apresenta apenas os valores médios da altura de plantas para os diferentes níveis de salinidade do solo franco-arenoso. Entretanto para esse caso não houve diferenças significativas pelo teste de $\mathrm{F}$ e a variável apresentou um valor médio geral de $108,18 \mathrm{~cm}$.

Os resultados analisados aos $150 \mathrm{DAT}$, podem ser verificados no gráfico (E) da Figura 37, onde os valores médios não apresentaram correlação em relação aos níveis de salinidade inicial do solo. Apesar da redução na altura de plantas a partir do nível de salinidade do solo de $5 \mathrm{dS} \mathrm{m}^{-1}$ a discrepância dos valores médios em relação ao ajuste proporcionou um coeficiente de determinação não significativo. Este fato pode ser explicado em virtude da própria arquitetura da planta de pimentão, ou seja, os frutos ao término de sua formação promoviam uma carga aos ramos ponteiros e reduziam assim a altura das plantas que apresentaram um valor médio para ambos os tratamentos de $109,43 \mathrm{~cm}$.

Os valores médios de altura de plantas encontrados ao final do ciclo assemelham-se aos obtidos por Tivelli (1999) e Villas Bôas (2001), os quais trabalhando com o mesmo híbrido determinaram alturas médias de $1,08 \mathrm{~cm} \mathrm{e} 1,09 \mathrm{~cm}$, respectivamente. Esses resultados asseguram que não ocorreu limitação no crescimento das plantas ocasionada pelo plantio em vasos, visto que, tanto no presente experimento quanto no realizado por Villas Bôas (2001) (também cultivado em vasos) os resultados não diferiram do experimento conduzido no solo por Tivelli (1999), além de que os rendimentos alcançados em ambos experimentos realizados em vasos foram superiores ao realizado no solo. 


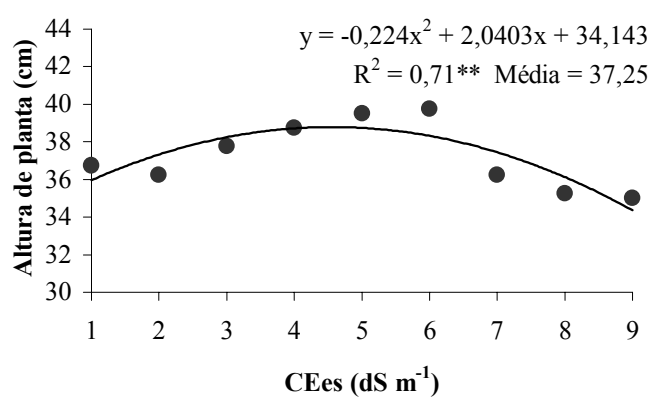

(A)

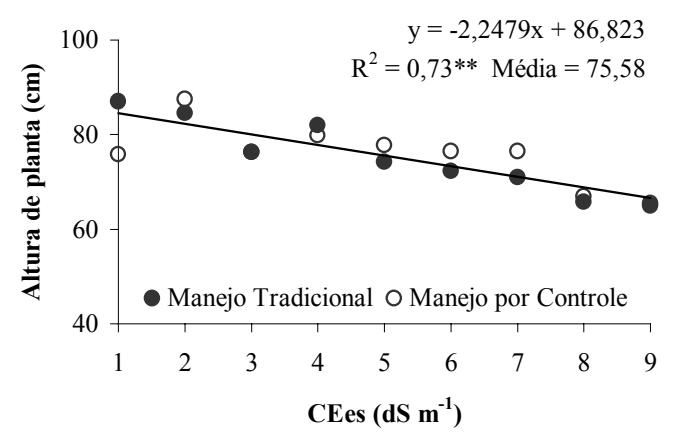

(C)

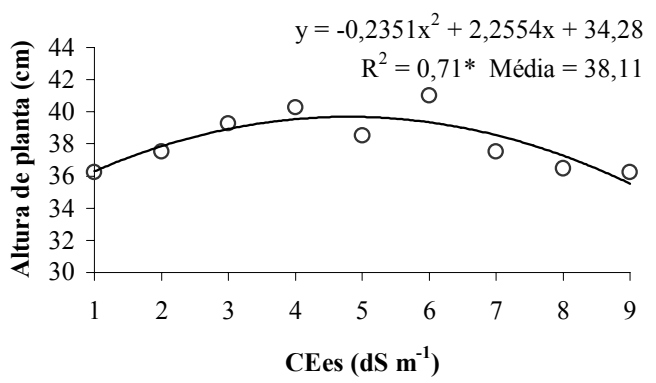

(B)

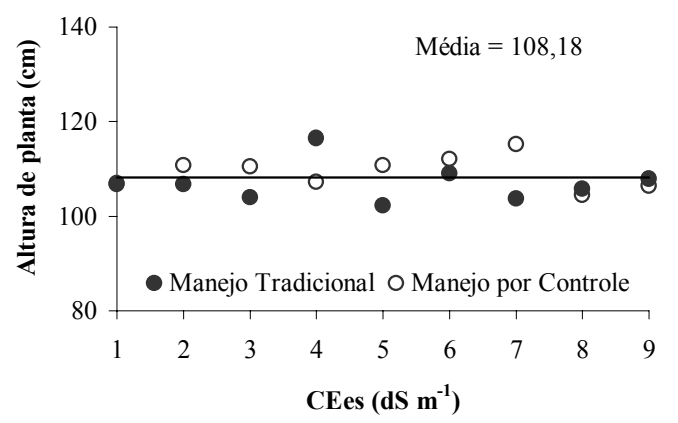

(D)

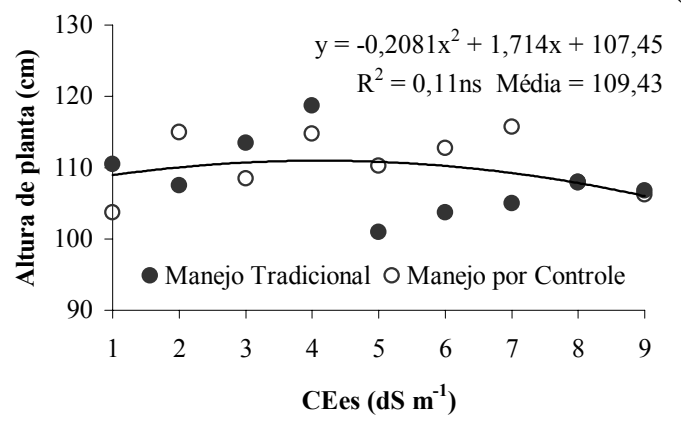

(E)

Figura 37 - Diagrama de dispersão e equação de ajuste para o solo franco-arenoso entre: (A) altura de planta aos 30 DAT com o manejo tradicional da fertirrigação, (B) altura de planta aos 30 DAT com o manejo controlado da fertirrigação, (C) altura de planta aos 70 DAT para ambos os manejos da fertirrigação, (D) altura de planta aos 130 DAT para ambos os manejos da fertirrigação e (E) altura de planta aos 150 DAT para ambos os manejos da fertirrigação e a salinidade inicial do solo

$\mathrm{Na}$ Tabela 12 verifica-se que a salinidade inicial do solo afetou significativamente a altura das plantas para o solo franco-argiloso. O manejo da fertirrigação só proporcionou diferenças significativas para as análises realizadas aos 70 DAT e aos 130 DAT. 
Tabela 12. Resumo da análise de variância para altura de planta em função de níveis de salinidade, em função de níveis de salinidade e manejo da fertirrigação para o solo franco-argiloso

\begin{tabular}{|c|c|c|c|c|}
\hline \multirow{3}{*}{$\begin{array}{l}\text { Causa da } \\
\text { Variação }\end{array}$} & \multirow{2}{*}{\multicolumn{4}{|c|}{$\begin{array}{c}\text { Estatística F } \\
\text { Altura de Planta }\end{array}$}} \\
\hline & & & & \\
\hline & 30 dias & 70 dias & 130 dias & 150 dias \\
\hline \multicolumn{5}{|l|}{ Tratamentos: } \\
\hline Blocos & 1,66 & 0,28 & 2,54 & 1,09 \\
\hline Salinidade (N) & $3,99 * *$ & $7,66 * *$ & $4,25 * *$ & $3,60 * *$ \\
\hline Manejo (M) & 0,05 & $26,03 * *$ & $20,44^{* *}$ & 3,64 \\
\hline \multicolumn{5}{|l|}{ Interações: } \\
\hline $\mathrm{N} \times \mathrm{M}$ & 1,66 & 0,28 & 2,54 & 1,09 \\
\hline
\end{tabular}

A Figura 38 apresenta o monitoramento da altura de plantas ao longo do ciclo da cultura para os diferentes manejos de fertirrigação e para o solo franco-argiloso. Nota-se que o crescimento para ambos os tratamentos mostrou-se uniforme até a terceira semana após o transplantio. Pode-se observar que a partir desse ponto a altura das plantas passa a ser influenciada pelos diferentes tratamentos. Assim como ocorreu no solo franco-arenoso, em alguns períodos do ciclo, nota-se decréscimo da altura das plantas, possivelmente esses decréscimos ocorrem, justamente, nos momentos em que as plantas estavam com uma grande carga de frutos, e assim, os ramos superiores apresentavam altura menor em relação às semanas anteriores. Visto que, a altura de planta era medida tendo como referencia superior o ápice do ramo mais alto e como referência inferior a superfície do solo. 


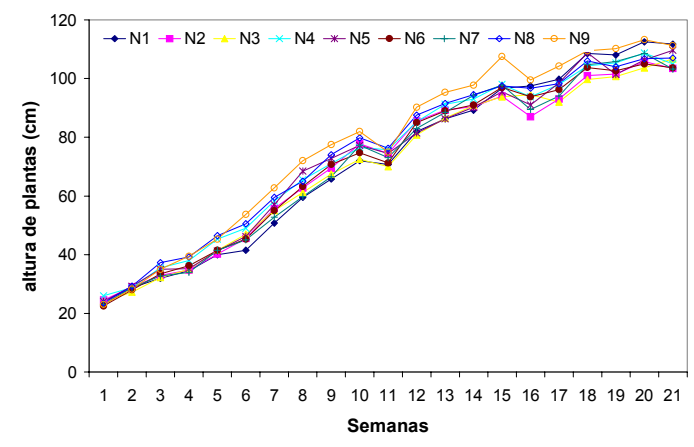

(A)

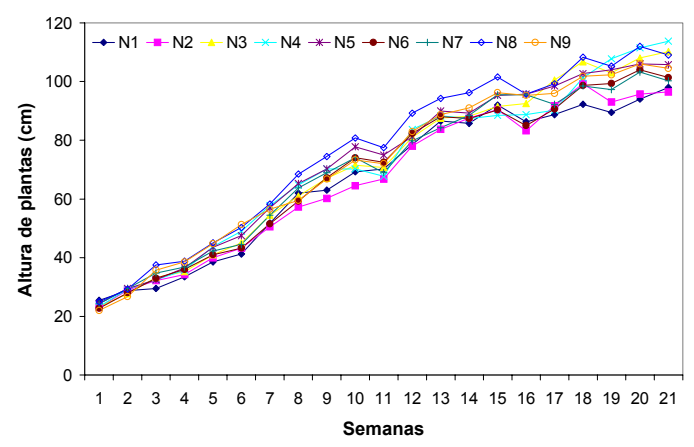

(B)

Figura 38 - Altura de plantas para os diferentes níveis de salinidade: (A) manejo tradicional de fertirrigação e (B) manejo controlado de fertirrigação para o solo franco-argiloso

$\mathrm{Na}$ Figura 39 pode-se verificar que a altura de plantas cultivadas no solo franco-arenoso, para os diferentes manejos de fertirrigação e aos 30 dias após transplante, mostrou uma tendência de incremento com um aumento da salinidade inicial do solo, com um ajuste quadrático e com um coeficiente de determinação $\left(R^{2}\right)$ de 0,76 , o que retrata uma boa correlação entre altura de plantas e a salinidade inicail do solo. Aos 70 dias após o transplante, para o manejo da fertirrigação tradicional e controlado a tendência também foi crescente, entretanto os ajustes foram linear. O coeficiente de determinação de 0,51 e de 0,57 não mostra uma forte correlação entre as variáveis. Aos 130 dias após o transplante, para o manejo da fertirrigação controlado não houve diferença significativa e o valor médio foi de 100,22 cm. Todavia para o manejo tradicional apesar de não apresentar uma tendência não definida o ajuste foi quadrático e o coeficiente de determinação foi de 0,76 . Para a regressão realizada com os dados referentes aos 150 dias a dispersão ocasionou a não significância do coeficiente de determinação, mostrando assim que não existe correlação entre as variáveis. 


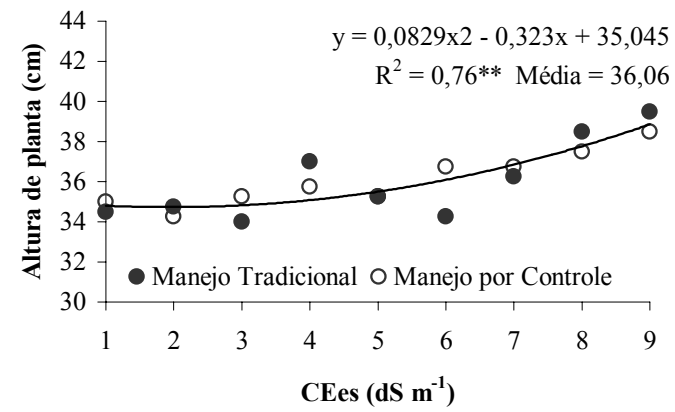

(A)

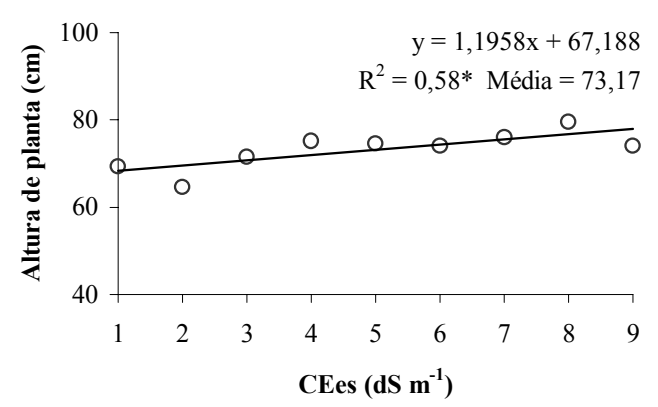

(C)

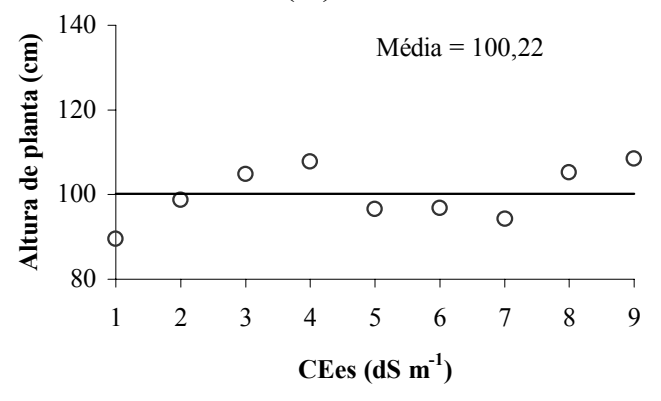

(E)

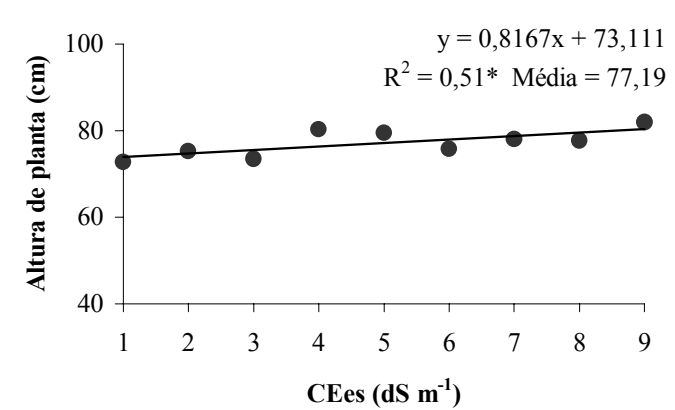

(B)

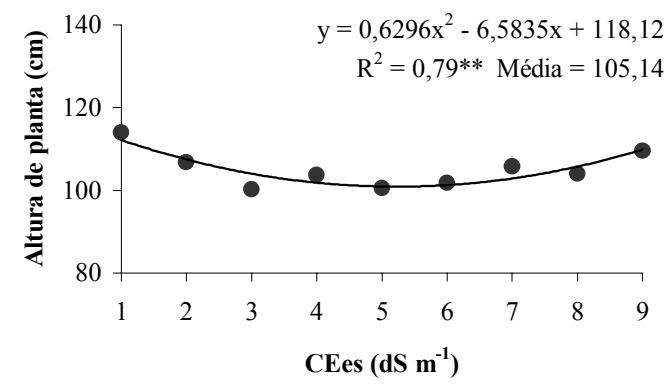

(D)

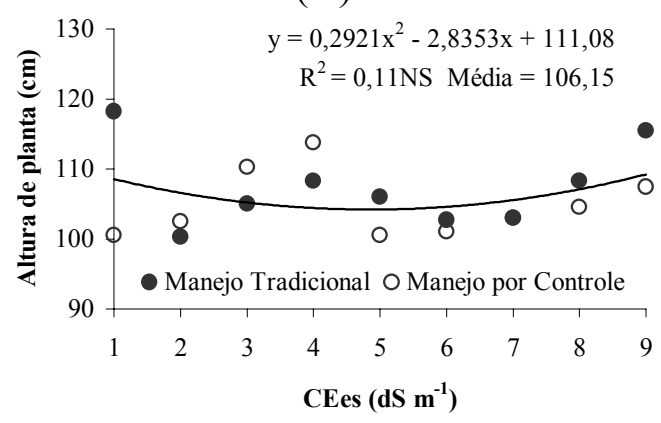

(F)

Figura 39 - Diagrama de dispersão e equação de ajuste para o solo franco-argiloso entre: (A) altura de planta aos 30 DAT para ambos os manejos da fertirrigação, (B) altura de planta aos 70 DAT com o manejo tradicional da fertirrigação, (C) altura de planta aos 70 DAT com o manejo controlado da fertirrigação, (D) altura de planta aos 130 DAT com o manejo tradicional da fertirrigação, (E) altura de planta aos 130 DAT com o manejo controlado da fertirrigação e (F) altura de planta aos 150 DAT para ambos os manejos de fertirrigação e a salinidade inicial do solo 


\subsubsection{Diâmetro de colo}

$\mathrm{Na}$ Tabela 13 pode-se verificar que para as diferentes épocas estudadas a variável diâmetro de colo diferiu significativamente em função da salinidade inicial do solo, do tipo de solo e da interação entre esses fatores. $\mathrm{O}$ manejo da fertirrigação afetou significativamente o diâmetro de colo apenas para 150 DAT. Como a interação entre salinidade e solo foi significativa, estudou-se a variável para cada tipo de solo.

Assim como nas demais variáveis de crescimento, as tendências discrepantes em relação ao diferentes solos fortalecem a consistência dos resultados e reforçam a tese que a distribuição da sais no vaso pode ter favorecido as plantas cultivadas no solo franco-argiloso.

Tabela 13. Resumo da análise de variância para diâmetro de colo, em função de níveis de salinidade, para diferentes tipos de solo e manejo

\begin{tabular}{ccccc}
\hline \multirow{2}{*}{$\begin{array}{c}\text { Causa da } \\
\text { Variação }\end{array}$} & \multicolumn{4}{c}{ Estatística F } \\
& 30 dias & 70 dias & 130 dias & 150 dias \\
\hline Tratamentos: & & & \\
Blocos & $4,88^{* *}$ & 1,09 & $3,63^{*}$ & $4,52^{* *}$ \\
Salinidade (N) & $4,29^{* *}$ & $5.78^{* *}$ & $3,01^{* *}$ & $7,60^{* *}$ \\
Solo (S) & $173,12^{* *}$ & $69.00^{* *}$ & $7,13^{* *}$ & $14,24^{* *}$ \\
Manejo (M) & 0,20 & 0,26 & 0,47 & $17,74^{* *}$ \\
Interações: & & & & \\
N x S & $4,81 * *$ & $12.58^{* *}$ & $6,48^{* *}$ & $8,68^{* *}$ \\
N x M & 1,21 & 1,41 & $2,02^{*}$ & $3,55^{* *}$ \\
S x M & 0,50 & $12.04^{* *}$ & 0,27 & 1,08 \\
N x S x M & 1,39 & 1,33 & $3,30^{* *}$ & $4,86^{* *}$ \\
\hline
\end{tabular}

** Significativo ao nível de $1 \%$ de probabilidade pelo teste $\mathrm{F}$

* Significativo ao nível de 5\% de probabilidade pelo teste $\mathrm{F}$

$\mathrm{Na}$ Tabela 14 pode-se observar que para o solo franco-arenoso o diâmetro de colo foi influenciado significativamente pela salinidade em todas as épocas analisadas. Apenas aos 150 DAT o manejo da fertirrigação afetou significativamente o diâmetro de colo. 
Tabela 14. Resumo da análise de variância para diâmetro de colo, em função de níveis de salinidade e manejo da fertirrigação para o solo franco-arenoso

\begin{tabular}{|c|c|c|c|c|}
\hline \multirow{3}{*}{$\begin{array}{l}\text { Causa da } \\
\text { Variação }\end{array}$} & \multirow{2}{*}{\multicolumn{4}{|c|}{$\begin{array}{c}\text { Estatística F } \\
\text { Diâmetro de Colo }\end{array}$}} \\
\hline & & & & \\
\hline & 30 dias & 70 dias & 130 dias & 150 dias \\
\hline \multicolumn{5}{|l|}{ Tratamentos: } \\
\hline Blocos & $2,80 *$ & 0,79 & $4,23 * *$ & 2,36 \\
\hline Salinidade (N) & $2,14^{*}$ & $7,06 * *$ & $4,66 * *$ & $4,64 * *$ \\
\hline Manejo (M) & 0,03 & 3,80 & 1,08 & $5,33 *$ \\
\hline \multicolumn{5}{|l|}{ Interações: } \\
\hline $\mathrm{N} \times \mathrm{M}$ & 0,50 & 1,43 & $3,44 * *$ & $6,66^{* *}$ \\
\hline
\end{tabular}

Na Figura 40 estão apresentados os valores de diâmetro de colo ao longo do ciclo da cultura para os diferentes manejos de fertirrigação e para o solo franco arenoso. Os valores de diâmetro de colo passam a variar entre tratamentos a partir da segunda semana e apresentam crescimento homogêneo ao longo de todo o ciclo.

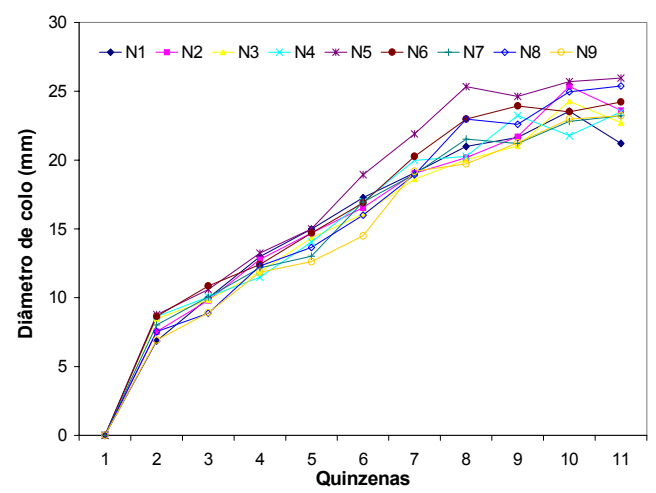

(A)

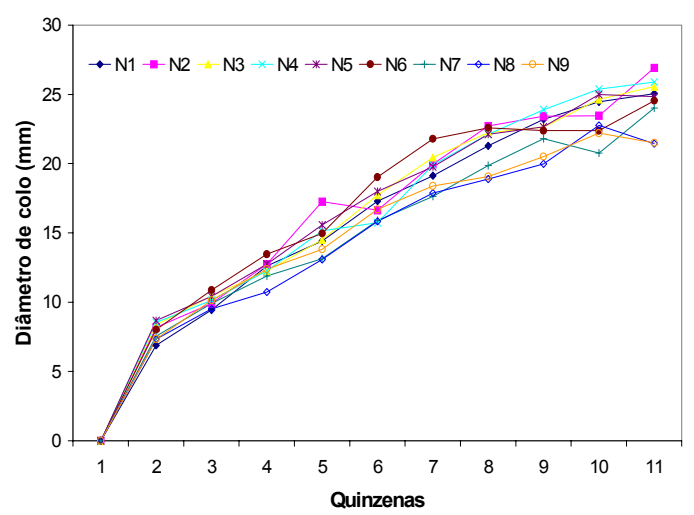

(B)

Figura 40 - Diâmetro de colo para os diferentes níveis de salinidade: (A) manejo tradicional de fertirrigação e (B) manejo controlado de fertirrigação para o solo franco-arenoso

As regressões de diâmetro de colo em função da salinidade do solo estão dispostas na Figura 41. Para as análises realizadas aos 30 DAT, 70 DAT e 130 DAT o ajuste foi polinomial quadrático com uma ligeira tendência a queda em função do 
incremento na salinidade. Os valores de $\mathrm{R}^{2}$ retratam a dispersão dos pontos em relação a reta ajustada.

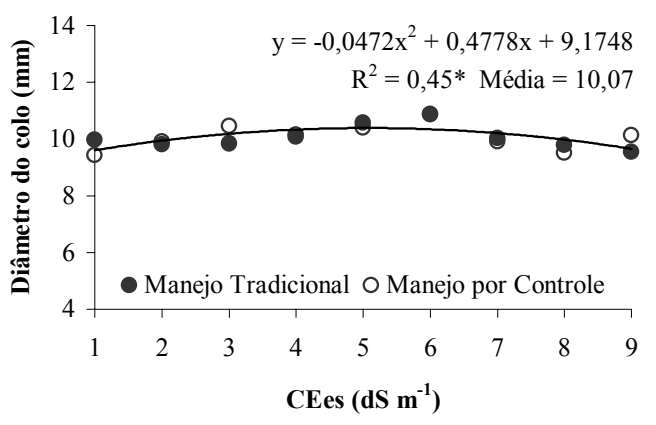

(A)

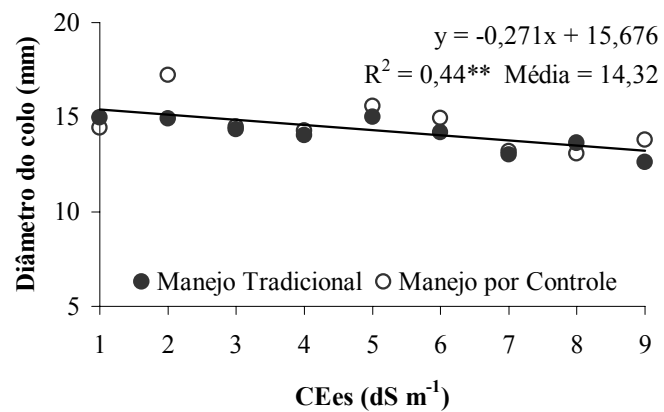

(B)

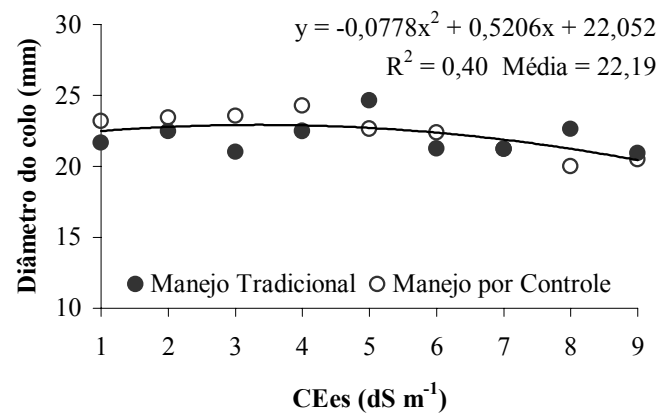

(C)

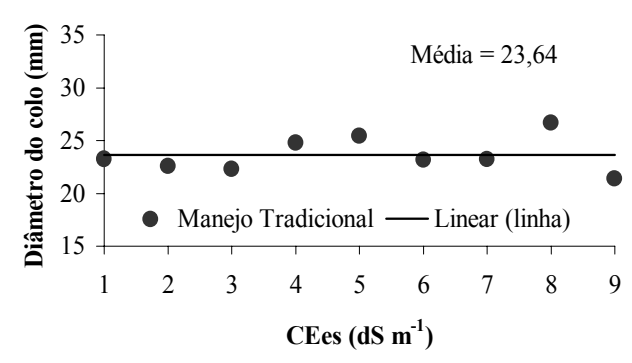

(D)

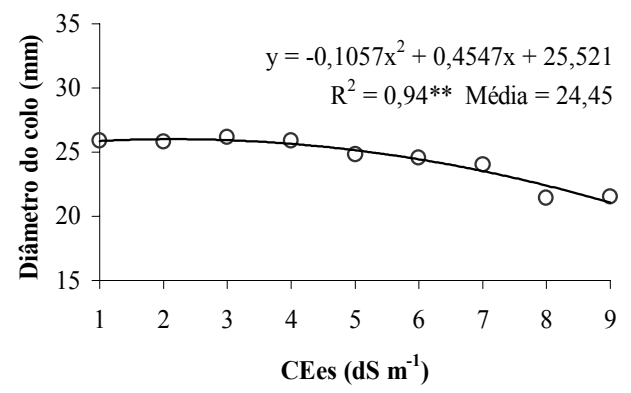

(E)

Figura 41 - Diagrama de dispersão e equação de ajuste para o solo franco-arenoso entre: (A) diâmetro de colo aos 30 DAT para ambos os manejos da fertirrigação, (B) diâmetro de colo aos 70 DAT para ambos os manejos da fertirrigação, (C) diâmetro de colo aos 130 DAT para ambos os manejos da fertirrigação, (D) diâmetro de colo aos 150 DAT com o manejo tradicional da fertirrigação, e (E) diâmetro de colo aos 150 DAT com o manejo controlado da fertirrigação e a salinidade inicial do solo 
$\mathrm{Na}$ Tabela 15 pode-se observar que para o solo franco-argiloso o diâmetro de colo foi influenciado significativamente pela salinidade em todas as épocas analisadas. Apenas aos 70 DAT e aos 150 DAT o manejo da fertirrigação afetou significativamente o diâmetro de colo.

Tabela 15. Resumo da análise de variância para diâmetro de colo, em função de níveis de salinidade e manejo da fertirrigação para o solo franco-argiloso

Causa da

Variação

Tratamentos:

Blocos

Salinidade (N)

Manejo (M)

Interações:

N x M 2,40*

** Significativ

* Significativo ao nível de $5 \%$ de probabilidade pelo teste $\mathrm{F}$
Estatística F

Diâmetro de Colo

30 dias 70 dias 130 dias

$\begin{array}{ccc}5,95^{* *} & 1,27 & 0,81 \\ 8,00^{* *} & 11,97 * * & 4,65^{* *} \\ 0,77 & 9,28^{* *} & 0,01 \\ & 1,27 & 2,20 * \\ 2,40 * & \text { nível de } 1 \% \text { de probabilidade pelo teste } \mathrm{F} \\ \text { nível de } 5 \% \text { de probabilidade pelo teste } \mathrm{F}\end{array}$
150 dias

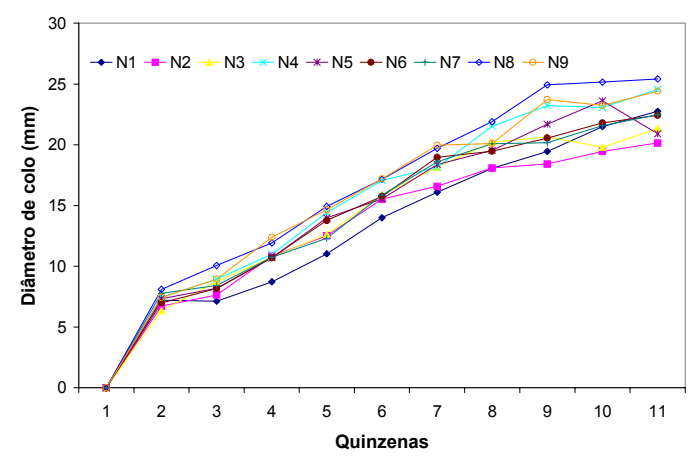

(A)

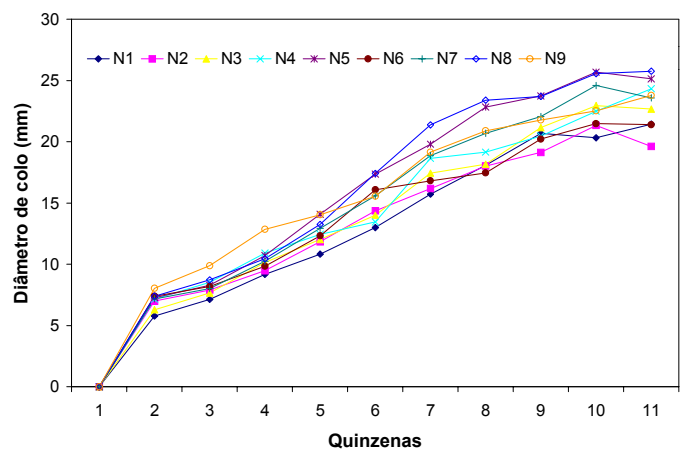

(B)

Figura 42 - Diâmetro de colo para os diferentes níveis de salinidade: (A) manejo tradicional de fertirrigação e (B) manejo controlado de fertirrigação para o solo franco-argiloso

Na Figura 42 estão apresentados os valores de diâmetro de colo ao longo do ciclo da cultura para os diferentes manejos de fertirrigação e para o solo franco argiloso. Os valores de diâmetro de colo passam a variar entre tratamentos a partir da segunda semana e apresenta crescimento homogêneo ao longo de todo o ciclo. 


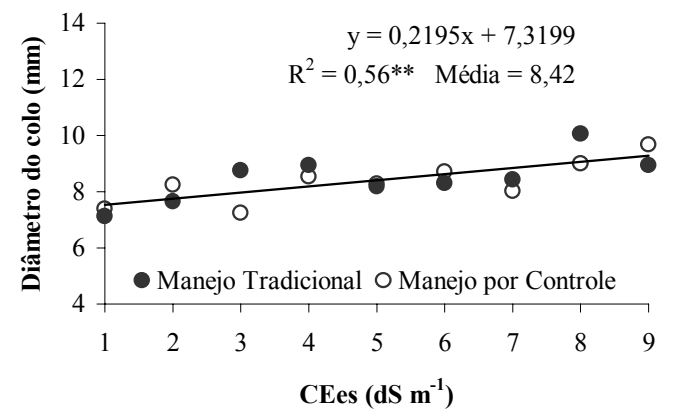

(A)

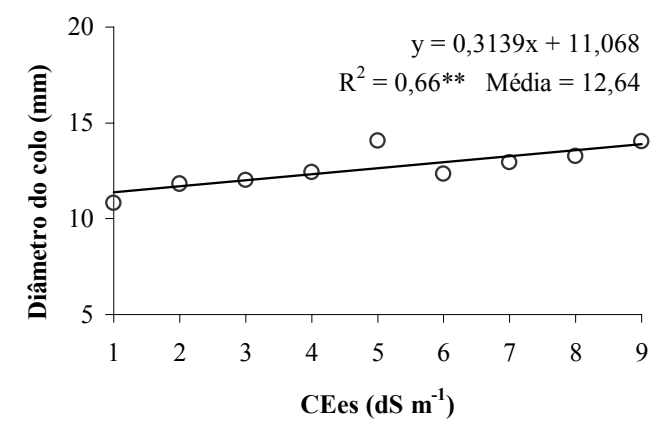

(C)

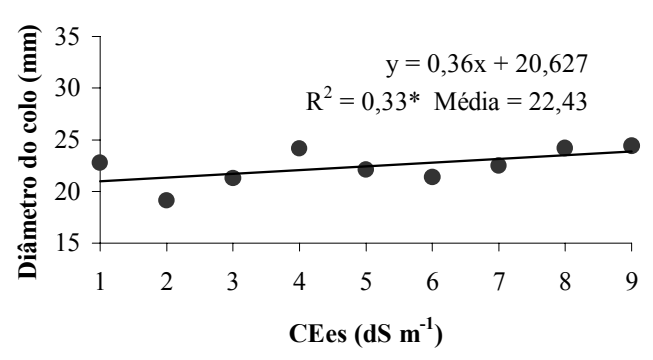

(E)

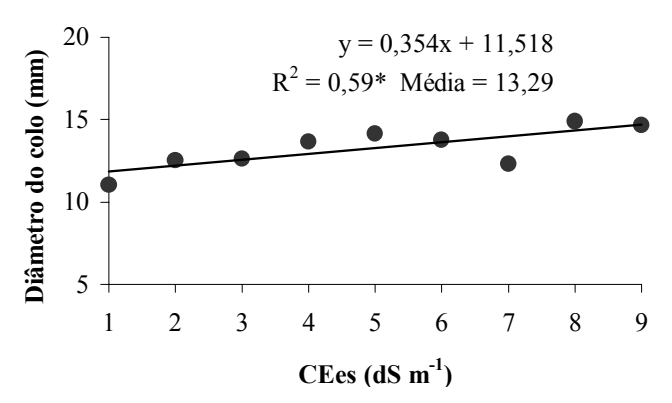

(B)

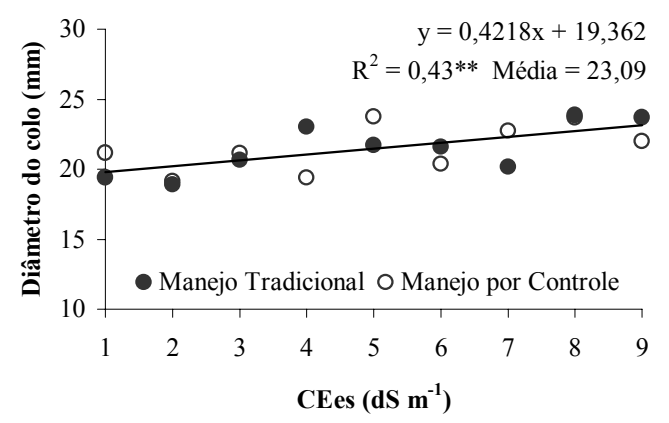

(D)

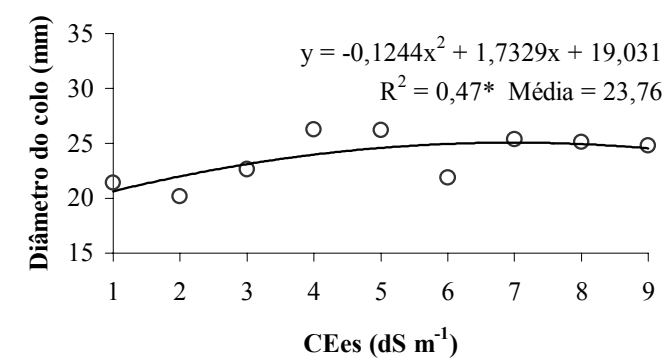

(F)

Figura 43 - Diagrama de dispersão e equação de ajuste para o solo franco-argiloso entre: (A) diâmetro de colo aos 30 DAT para ambos os manejos da fertirrigação, (B) diâmetro de colo aos 70 DAT com manejo tradicional da fertirrigação, (C) diâmetro de colo aos 70 DAT com manejo controlado da fertirrigação, (D) diâmetro de colo aos 130 DAT para ambos os manejos da fertirrigação (E) diâmetro de colo aos 150 DAT com o manejo tradicional da fertirrigação, e (F) diâmetro de colo aos 150 DAT com o manejo controlado da fertirrigação e a salinidade inicial do solo

As regressões de diâmetro de colo em função da salinidade do solo franco-argiloso estão dispostas na Figura 43. Para as análises realizadas aos 30 DAT, 70 DAT e 130 DAT o ajuste foi linear com uma ligeira tendência a ascenção em função do 
incremento na salinidade. Os valores de $\mathrm{R}^{2}$ retratam a dispersão dos pontos em relação a reta ajustada.

Todos os valores determinados ao final do ciclo em relação ao diâmetro de colo mostraram-se superiores aos valores obtidos por Villas Bôas (2001), o qual apresentou valores médios variando entre 12 e $19 \mathrm{~mm}$.

\subsubsection{Produção e componentes de produção}

\subsubsection{Rendimento da cultura}

Conforme os resultados apresentados na Tabela 16 pode-se observar que os rendimentos da cultura foram afetados pela salinidade do solo em todas as épocas analisadas, corroborando com os resultados alcançados por Medeiros (1998). O fator solo também foi significativo excetuando-se a análise para 78 dias após transplante (DAT). Entretanto, o manejo da fertirrigação apenas apresentou diferença significativa após 153 DAT. A significância das interações entre os fatores empregados sugere que esses sejam estudados separadamente, ou seja, que se desdobre a análise de variância.

Tabela 16. Resumo da análise de variância para rendimento em função de níveis de salinidade, para os diferentes tipos de solo e manejo estudados

\begin{tabular}{cccc}
\hline Causa da & \multicolumn{3}{c}{$\begin{array}{c}\text { Estatística F } \\
\text { Rendimento }(\mathrm{g}) \\
114 \text { dias }\end{array}$} \\
Variação & 78 dias & $5.34^{* *}$ & $9.72^{* *}$ \\
\hline Tratamentos: & & $15.25^{* *}$ & $15.50^{* *}$ \\
Blocos & 2,56 & $6.80^{*}$ & $10.62^{* *}$ \\
Salinidade (N) & $8.52^{* *}$ & 3,31 & $5.35^{*}$ \\
Solo (S) & 2,94 & & \\
Manejo (M) & 0,28 & $34.11^{* *}$ & $24.13^{* *}$ \\
Interações: & & $4.98^{* *}$ & $3.0^{* *}$ \\
N x S & $30.11^{* *}$ & $9.04^{* *}$ & 0,91 \\
N x M & $2.49 *$ & $3.24 * *$ & $2.21^{* *}$ \\
S x M & 2,36 & 1,93 & \\
N x S x M & &
\end{tabular}

** Significativo ao nível de $1 \%$ de probabilidade pelo teste $\mathrm{F}$

* Significativo ao nível de 5\% de probabilidade pelo teste $\mathrm{F}$ 
$\mathrm{Na}$ Tabela 17 verifica-se que para o solo franco-arenoso a salinidade do solo interferiu no rendimento da cultura para todas as épocas estudadas. Já o manejo da fertirrigação apresentou diferença significativa pelo teste de F ao nível de $1 \%$ e 5\%, para a análise realizada aos 114 e 153 DAT, respectivamente.

Tabela 17 - Resumo da análise de variância para rendimento em função de níveis de salinidade e manejo da fertirrigação para o solo franco-arenoso

\begin{tabular}{cccc}
\hline Causa da & \multicolumn{3}{c}{$\begin{array}{c}\text { Estatística F } \\
\text { Rendimento }(\mathrm{g}) \\
114 \text { dias }\end{array}$} \\
Variação & 78 dias & 153 dias \\
\hline Tratamentos: & 0,69 & 2,39 & $4,29 * *$ \\
Blocos & $34,96^{* *}$ & $28,54^{* *}$ & $29,93^{* *}$ \\
Salinidade (N) & 2,57 & $8,12^{* *}$ & $4,80^{*}$ \\
Manejo (M) & & & \\
Interações: & 1,22 & $2,12^{*}$ & 1,87 \\
N x M & &
\end{tabular}

** Significativo ao nível de $1 \%$ de probabilidade pelo teste $\mathrm{F}$

* Significativo ao nível de $5 \%$ de probabilidade pelo teste $\mathrm{F}$

As análises de regressão apresentadas na Figura 44 seguem um ajuste polinomial quadrático para todas a épocas em que foram realizadas para o solo francoarenoso. Os coeficientes de determinação $\left(\mathrm{R}^{2}\right)$, variando entre 0,76 e 0,95 , indicam uma boa correlação entre a salinidade do solo e a variável rendimento. Os valores de rendimentos médios são analisados separadamente para 114 DAT devido a diferente tendência das curvas para os manejos de fertirrigação tradicional e controlado.

Em média obteve-se ao final do experimento aproximadamente um rendimento de $2 \mathrm{~kg}$ por planta, assim representado dado o cultivo em vasos. Esse resultado está acima da média dos rendimentos obtidos pelos agricultores, mesmo sob condições desfavoráveis de estresse salino. Caso seja considerado o espaçamento entre os vasos e suas produções individuais pode-se quantificar um rendimento de aproximadamente $37.000 \mathrm{~kg} \mathrm{ha}^{-1}$. Villas Bôas (2001) alcançou uma produção máxima de 2,74 kg por planta utilizando o mesmo híbrido de pimentão (Elisa); o autor relata resultados de outros pesquisadores, os quais obtiveram rendimentos variando entre 1,30 e $2,78 \mathrm{~kg}$ por planta para o mesmo híbrido. 


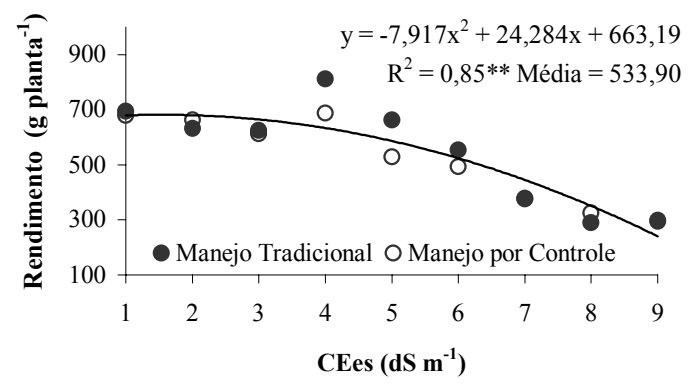

(A)

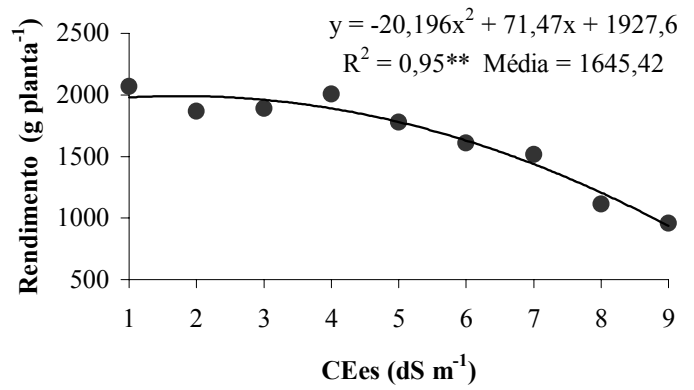

(B)

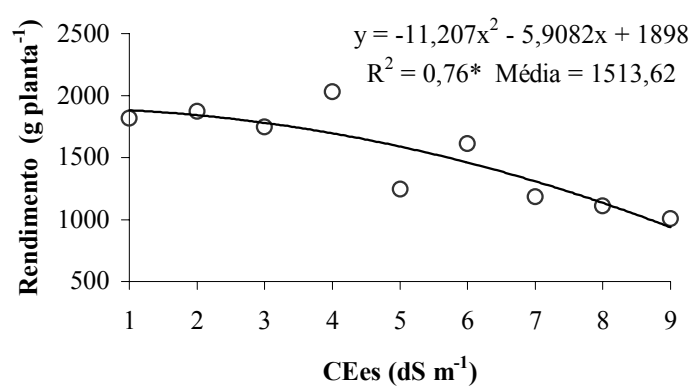

(C)

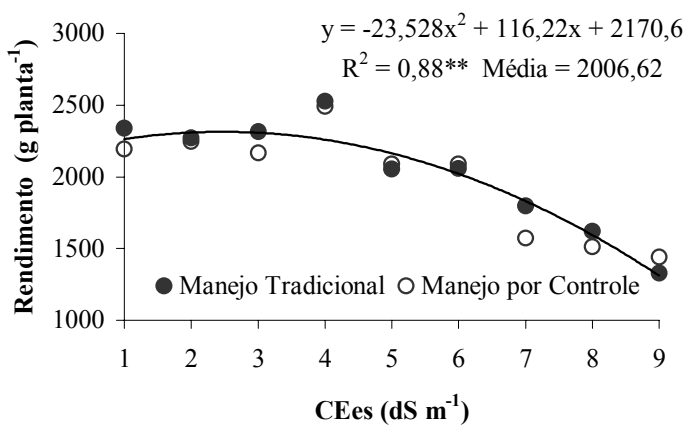

(D)

Figura 44 - Diagrama de dispersão e equação de ajuste para o solo franco-arenoso entre o rendimento até: (A) 78 DAT para ambos os manejos de fertirrigação, (B) 114 DAT para o manejo tradicional da fertirrigação, (C) 114 DAT para o manejo controlado da fertirrigação e (D) 153 DAT para ambos os manejos de fertirrigação e a salinidade inicial do solo

O rendimento foi influenciado significativamente pela salinidade do solo para o solo franco-argiloso para todos as épocas analisadas pelo teste de F, sendo as diferenças significativas a $1 \%$ de probabilidade (Tabela 18). O mesmo foi observado para interação entre salinidade e manejo, mostrando que a dispersão de dados entre os 
manejos foi diferenciada. Entretanto, a tendência entre os diferentes manejos mostrou-se semelhante e optou-se pela análise conjunta entre os tratamentos, nesse caso.

Tabela 18. Resumo da análise de variância para rendimento em função de níveis de salinidade e manejo da fertirrigação para o solo franco-argiloso

\begin{tabular}{|c|c|c|c|}
\hline \multirow{2}{*}{$\begin{array}{l}\text { Causa da } \\
\text { Variação }\end{array}$} & \multicolumn{3}{|c|}{$\begin{array}{c}\text { Estatística F } \\
\text { Rendimento }(\mathrm{g})\end{array}$} \\
\hline & 78 dias & 114 dias & 153 dias \\
\hline \multicolumn{4}{|l|}{ Tratamentos: } \\
\hline Blocos & 2,28 & $5,73 * *$ & $5,64 * *$ \\
\hline Salinidade (N) & $8,02 * *$ & $11,69 * *$ & $6,83 * *$ \\
\hline Manejo (M) & 0,43 & 1,28 & 0,99 \\
\hline \multicolumn{4}{|l|}{ Interações: } \\
\hline $\mathrm{N} \times \mathrm{M}$ & $2,86 * *$ & $9,36 * *$ & $3,41 * *$ \\
\hline
\end{tabular}

O rendimento alcançado para os diferentes tratamentos no solo francoargiloso apresentou um ajuste polinomial quadrático com uma fraca correlação entre a salinidade e a variável rendimento, com $\mathrm{R}^{2}$ variando entre 0,37 e 0,43 (Figura 45). As tendências das curvas obtidas pelas regressões indicam que a salinidade teve um efeito positivo no rendimento para as diferentes épocas de estudo. Este resultado, não esperado, possivelmente ocorreu em função da distribuição de sais no vaso, em virtude do sistema de irrigação por gotejamento e da alta freqüência de irrigação, além do que, o desenvolvimento do sistema radicular para o solo franco-argiloso foi inferior ao desenvolvimento observado visualmente no solo franco-arenoso e no solo francoargiloso quase a totalidade das raízes apresentava-se no local onde a salinidade do solo mostra os menores valores de condutividade elétrica. Outro aspecto possível de ser citado deve-se as relações entre os íons na forma solúvel e adsorvida, regida pelo tipo e quantidade de argila presente, isso permite uma menor variação na condutividade elétrica da solução, mesmo com a aplicação de fertilizante em maiores quantidades.

Os manejos de fertirrigação utilizados não diferiram economicamente, possivelmente em conseqüência da utilização de recomendações adequadas para um ciclo de cultivo. Entretanto, como já foi citado, cultivos sucessivos podem causar aumento na salinidade e redução nos rendimentos alcançados. 


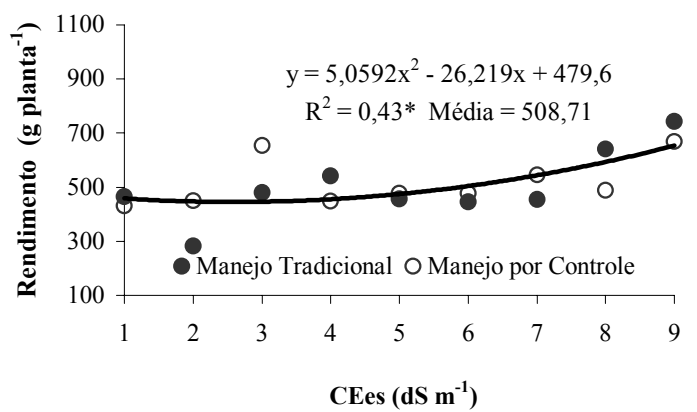

(A)

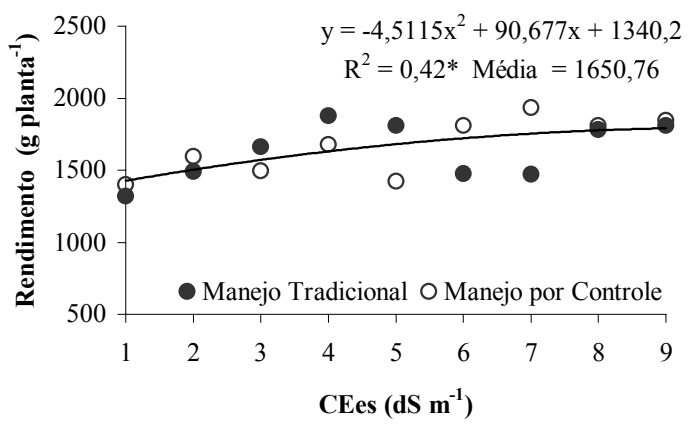

(B)

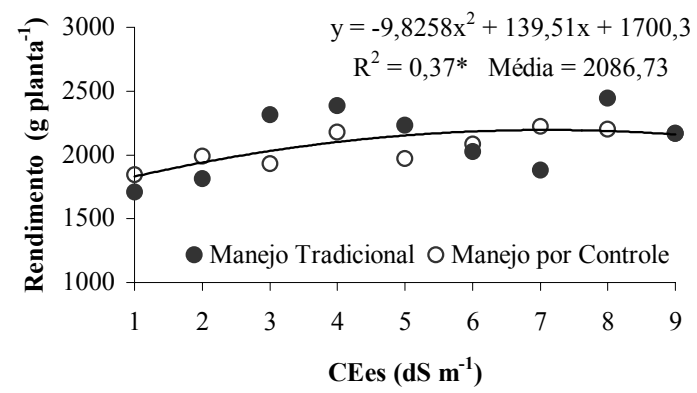

(C)

Figura 45 - Diagrama de dispersão e equação de ajuste para o solo franco-argiloso entre o rendimento até: (A) 78 DAT, (B) 114 DAT e (C) 153 DAT para os diferentes manejos de fertirrigação e a salinidade inicial do solo

\subsubsection{Peso médio de frutos}

O peso médio de frutos diferiu significativamente pelo teste de $\mathrm{F}$ para as três fases analisadas em relação ao fator solo. A salinidade apenas interferiu significativamente para a análise de variância realizada aos 114 DAT. As interações entre salinidade e solo foram significativas, assim sendo, torna-se necessário o estudo em separado para os diferentes solos utilizados no ensaio. Em relação ao manejo de fertirrigação, esse interferiu significativamente o peso médio de frutos ao final do ciclo (Tabela 19). 
Tabela 19. Resumo da análise de variância para peso médio de frutos em função de níveis de salinidade, para diferentes tipos de solo e manejo

\begin{tabular}{|c|c|c|c|}
\hline \multirow{2}{*}{$\begin{array}{l}\text { Causa da } \\
\text { Variação }\end{array}$} & \multicolumn{3}{|c|}{$\begin{array}{c}\text { Estatística F } \\
\text { Peso Médio de Frutos }(\mathrm{g})\end{array}$} \\
\hline & 78 dias & 114 dias & 153 dias \\
\hline \multicolumn{4}{|l|}{ Tratamentos: } \\
\hline Blocos & 0,43 & 0,80 & 65,94 \\
\hline Salinidade $(\mathrm{N})$ & 1,28 & $2.98 * *$ & 1,98 \\
\hline Solo (S) & $5.77 *$ & $31.35 * *$ & $6.76^{*}$ \\
\hline Manejo (M) & 1,01 & 3,83 & $10.32 * *$ \\
\hline \multicolumn{4}{|l|}{ Interações: } \\
\hline $\mathrm{N} \times \mathrm{S}$ & 1,79 & $3.18 * *$ & $5.69 * *$ \\
\hline $\mathrm{N} \times \mathrm{M}$ & 0,86 & 1,38 & 1,11 \\
\hline $\mathrm{S} \times \mathrm{M}$ & 0,40 & 0,74 & 0,51 \\
\hline $\mathrm{N} \times \mathrm{S} \times \mathrm{M}$ & 0,94 & 1,49 & 1,16 \\
\hline
\end{tabular}

$\mathrm{Na}$ Tabela 20 pode-se verificar que para o solo franco-arenoso os fatores salinidade inicial do solo e manejos de fertirrigação interferiram significativamente na variável peso médio de frutos ao nível de 1\% pelo teste de F após 114 DAT. Pode-se notar ainda que a interação entre ambos os tratamentos contribuiu nessa diferenciação para análise nos 114 DAT.

Tabela 20. Resumo da análise de variância para peso médio de frutos em função de níveis de salinidade e manejo da fertirrigação para o solo franco-arenoso

\begin{tabular}{|c|c|c|c|}
\hline \multirow{2}{*}{$\begin{array}{l}\text { Causa da } \\
\text { Variação }\end{array}$} & \multicolumn{3}{|c|}{$\begin{array}{c}\text { Estatística F } \\
\text { Peso Médio de Frutos }(\mathrm{g})\end{array}$} \\
\hline & 78 dias & 114 dias & 153 dias \\
\hline \multicolumn{4}{|l|}{ Tratamentos: } \\
\hline Blocos & 0,43 & $3,05^{*}$ & $29,35 * *$ \\
\hline Salinidade $(\mathrm{N})$ & 2,08 & $12,28 * *$ & $6,63 * *$ \\
\hline Manejo (M) & 1,70 & $8,32 * *$ & $7,91 * *$ \\
\hline \multicolumn{4}{|l|}{ Interações: } \\
\hline $\mathrm{N} \times \mathrm{M}$ & 1,04 & $3,23 * *$ & 1,34 \\
\hline
\end{tabular}

** Significativo ao nível de $1 \%$ de probabilidade pelo teste $\mathrm{F}$

* Significativo ao nível de 5\% de probabilidade pelo teste $\mathrm{F}$ 
A Figura 46 apresenta as regressões para o solo franco-arenoso em diferentes épocas de análise e para os diferentes manejos de fertirrigação. De maneira geral, com o incremento da salinidade ocorreu um decréscimo no peso médio dos frutos, sendo o melhor ajuste linear ou polinomial quadrático.

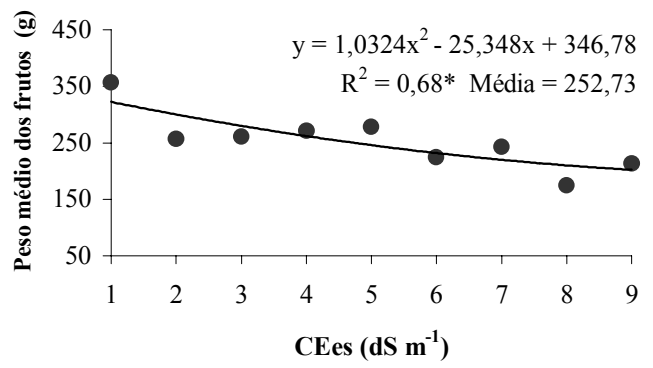

(A)

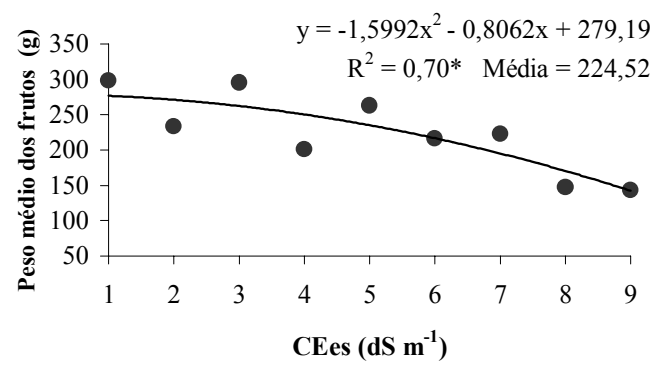

(C)

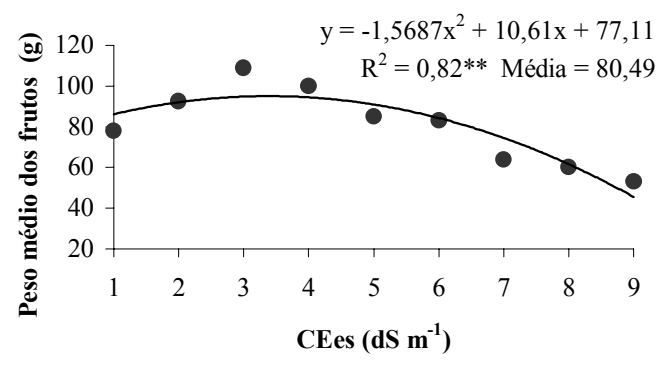

(E)

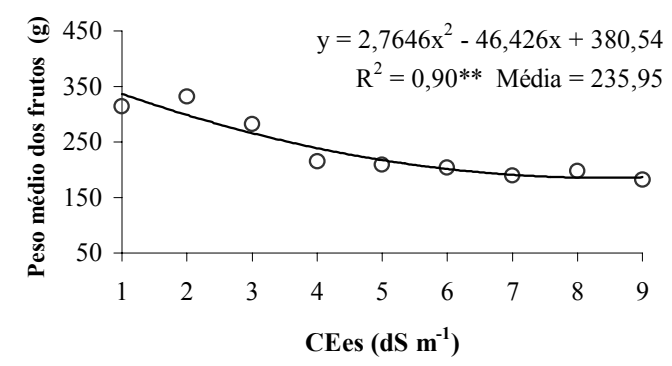

(B)

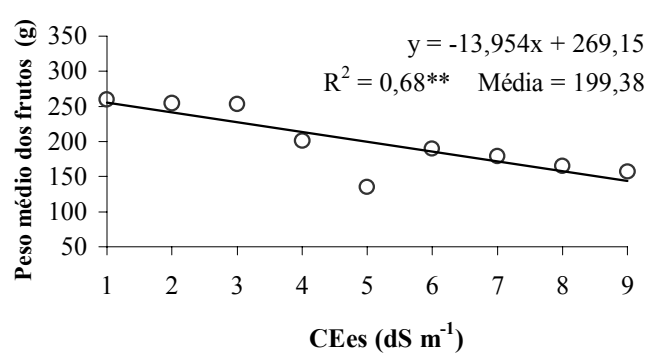

(D)

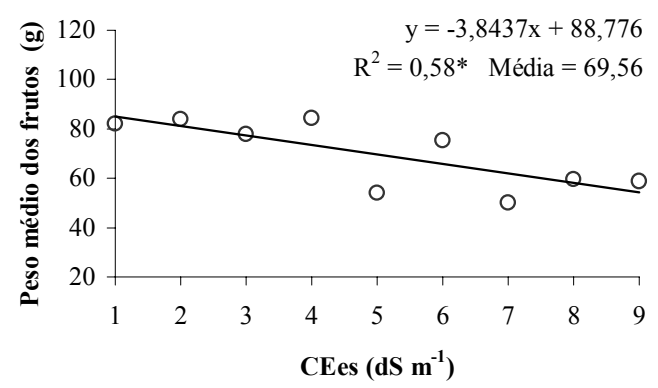

(F)

Figura 46 - Diagrama de dispersão e equação de ajuste para o solo franco-arenoso entre o peso médio de frutos até: (A) 78 DAT para o manejo tradicional da fertirrigação, (B) 78 DAT para o manejo controlado da fertirrigação, (C) 114 DAT para o manejo tradicional da fertirrigação, (D) 114 DAT para o manejo controlado da fertirrigação, (E)153 DAT para o manejo tradicional da fertirrigação e (F)153 DAT para o manejo controlado da fertirrigação e a salinidade inicial do solo 
Em média o manejo de fertirrigação tradicional superou o controlado com valores respectivos de $252,73 \mathrm{~g}$ por fruto e $235,95 \mathrm{~g}$ por fruto aos $78 \mathrm{DAT}$, de $224,52 \mathrm{~g}$ por fruto e $199,38 \mathrm{~g}$ por fruto aos $114 \mathrm{DAT}$ e $80,49 \mathrm{~g}$ por fruto e $69,56 \mathrm{~g}$ por fruto aos 153 DAT. Dessa forma nota-se uma redução no peso médio do fruto ao longo do tempo.

Em relação ao solo franco-argiloso, como pode ser observado na Tabela 21, não ocorreu efeito significativo dos fatores salinidade inicial do solo e manejo da fertirrigação sobre a variável peso médio de frutos.

Tabela 21. Resumo da análise de variância para peso médio de frutos em função de níveis de salinidade e manejo da fertirrigação para o solo franco-argiloso

\begin{tabular}{|c|c|c|c|}
\hline \multirow{2}{*}{$\begin{array}{l}\text { Causa da } \\
\text { Variação }\end{array}$} & \multicolumn{3}{|c|}{$\begin{array}{c}\text { Estatística F } \\
\text { Peso Médio de Frutos }(\mathrm{g})\end{array}$} \\
\hline & 78 dias & 114 dias & 153 dias \\
\hline \multicolumn{4}{|l|}{ Tratamentos: } \\
\hline Blocos & 0,96 & 0,68 & $36,76^{* *}$ \\
\hline Salinidade (N) & 1,18 & 0,21 & 1,15 \\
\hline Manejo (M) & 0,06 & 0,41 & 3,01 \\
\hline \multicolumn{4}{|l|}{ Interações: } \\
\hline $\mathrm{N} x \mathrm{M}$ & 0,81 & 0,90 & 0,93 \\
\hline
\end{tabular}

** Significativo ao nível de $1 \%$ de probabilidade pelo teste $\mathrm{F}$

* Significativo ao nível de $5 \%$ de probabilidade pelo teste $\mathrm{F}$

Na Figura 47 estão dispostos os valores médios do peso médio de frutos para o solo franco-argiloso em função da salinidade do solo e uma reta representando o valor médio para cada fase analisada. O peso médio de frutos obtido foi de 299,28 g por fruto até 78 DAT, 261,95 g por fruto até 114 DAT e 82,26 g por fruto 153 DAT. Novamente, como aconteceu com o solo franco-arenoso, o peso médio de frutos foi reduzido ao longo do ciclo da cultura, concordando com os resultados obtidos por Medeiros (1998). 


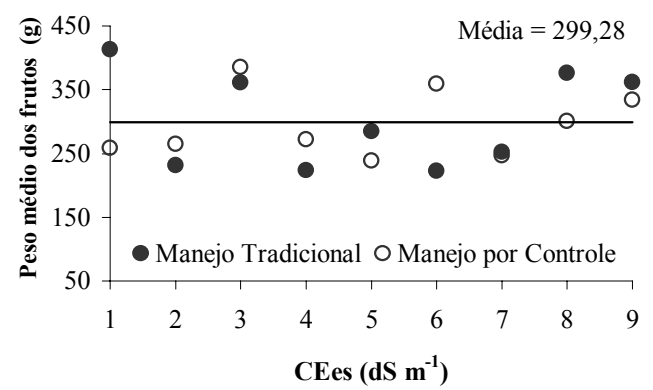

(A)

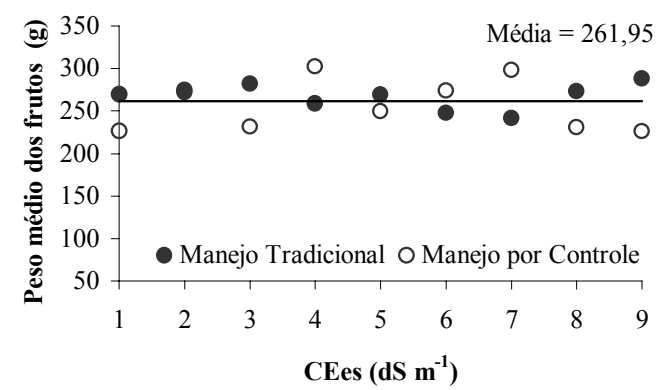

(B)

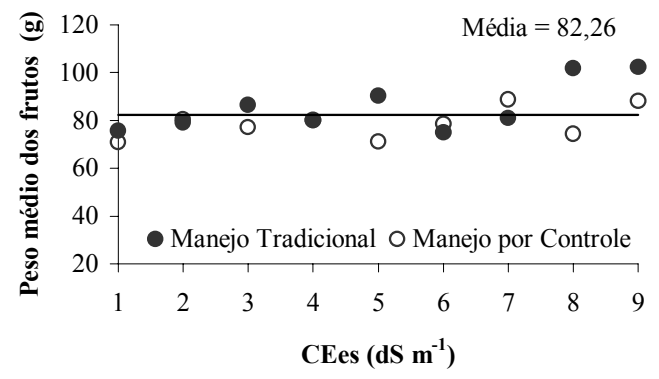

(C)

Figura 47 - Diagrama de dispersão e equação de ajuste para o solo franco-argiloso entre o peso médio de frutos até: (A) 78 DAT, (B) 114 DAT e (C) 153 DAT para os diferentes manejos de fertirrigação e a salinidade inicial do solo

\subsubsection{Número de frutos}

O número de frutos por planta foi analisado aos 78 DAT, 114 DAT e 153 DAT (Tabela 22). A salinidade inicial do solo mostrou efeito significativo apenas para a análise realizada aos 114 DAT. Todavia, o fator solo diferiu significativamente para as análises aos 78 DAT e 114 DAT, assim como as interações entre os fatores salinidade e solo. Procedeu-se assim a analise de variância tanto para o solo franco-arenoso como para o solo-franco argiloso de forma separada. 
Tabela 22. Resumo da análise de variância para número de frutos em função de níveis de salinidade, para diferentes tipos de solo e manejo

\begin{tabular}{cccc}
\hline $\begin{array}{c}\text { Causa da } \\
\text { Variação }\end{array}$ & 78 dias & $\begin{array}{c}\text { Estatística F } \\
\text { Número de Frutos } \\
114 \text { dias }\end{array}$ \\
\hline Tratamentos: & 2,21 & $4.78^{* *}$ & $243.57^{* *}$ \\
Blocos & 1,66 & $4.11^{* *}$ & 0,95 \\
Salinidade (N) & $14.30^{* *}$ & $25.32^{* *}$ & 2,44 \\
Solo (S) & 0,07 & 2,67 & 2,44 \\
Manejo (M) & & & \\
Interações: & $2.81^{* *}$ & $2.96^{* *}$ & 0,72 \\
N x S & 0,40 & 0,68 & 0,11 \\
N x M & 0,29 & 0,40 & 0,58 \\
S x M & 1,44 & 1,71 & 1,21 \\
N x S x M &
\end{tabular}

** Significativo ao nível de $1 \%$ de probabilidade pelo teste $\mathrm{F}$

$\mathrm{Na}$ Tabela 23 pode-se verificar que para o solo franco-arenoso a salinidade interferiu no número de frutos nas análises de variância realizadas com os dados referentes a 78 DAT e 114 DAT. Para o manejo da fertirrigação não houve diferenças significativas pelo teste de F.

Tabela 23. Resumo da análise de variância para número de frutos em função de níveis de salinidade e manejo da fertirrigação para o solo franco-arenoso

\begin{tabular}{|c|c|c|c|}
\hline $\begin{array}{l}\text { Causa da } \\
\text { Variação }\end{array}$ & \multicolumn{3}{|c|}{$\begin{array}{c}\text { Estatística F } \\
\text { Número de Frutos }\end{array}$} \\
\hline Tratamentos: & & & \\
\hline Blocos & 1,41 & $3,31 *$ & $118,08 * *$ \\
\hline Salinidade (N) & $2,98 * *$ & $5,65 * *$ & 0,80 \\
\hline Manejo (M) & 0,31 & 0,54 & 2,60 \\
\hline Interações: & & & \\
\hline $\mathrm{N} \times \mathrm{M}$ & 0,62 & 1,59 & 0,82 \\
\hline
\end{tabular}

O ajuste polinomial quadrático foi o que apresentou melhor correlação para a análise de regressão referente aos dados até 78 DAT e 114 DAT, apresentando um coeficiente de determinação $\left(\mathrm{R}^{2}\right)$ igual à 0,63 e 0,28 , respectivamente. Assim sendo, 
observa-se que a variável não apresentou uma forte correlação com a salinidade inicial para o solo franco-arenoso (Figura 48). A análise para os dados até 153 DAT não apresentou diferença significativa, todavia, na Figura 37 estão apresentados os valores médios em função da salinidade, os quais apresentaram uma média geral de 28,94 frutos por planta.

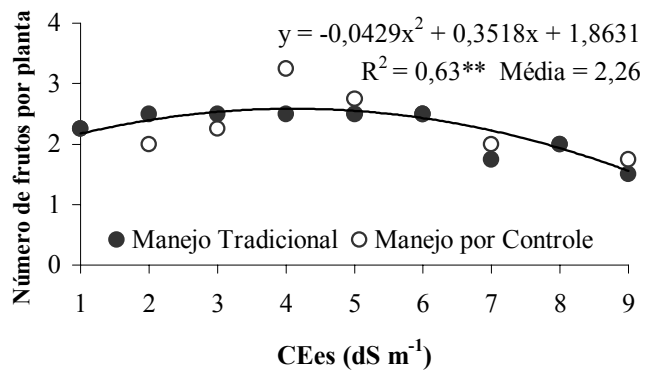

(A)

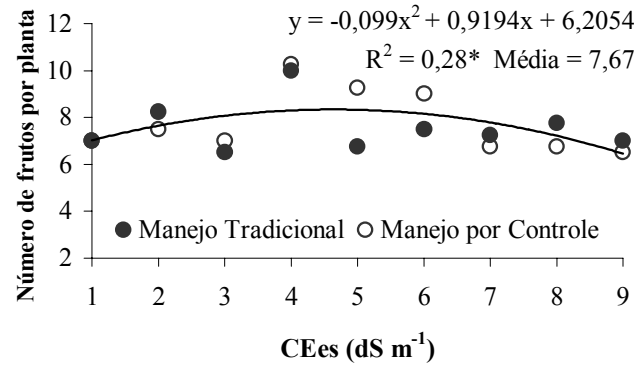

(B)

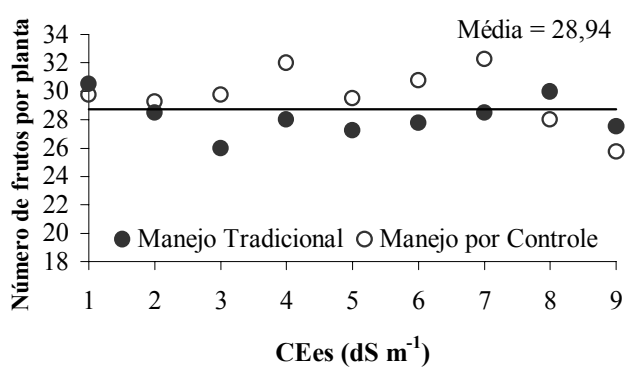

(C)

Figura 48 - Diagrama de dispersão e equação de ajuste para o solo franco-arenoso entre o número de frutos aos: (A) 78 DAT, (B) 114 DAT e (C) 153 DAT para os diferentes manejos de fertirrigação e a salinidade inicial do solo

O número de frutos por planta para o solo franco-argiloso não diferiu significativamente pelo teste de $\mathrm{F}$ em função de nenhum dos fatores empregados (Tabela 24).

Discordando do que foi abordado por Medeiros (1998), a redução nos rendimentos alcançados para o solo franco-arenoso foi influenciada mais pelo peso médio dos frutos que pelo número de frutos. Medeiros (1998) encontrou números de frutos variando entre 20 e 14 frutos por planta ao final do ciclo, no presente experimento o número de frutos variou em torno de 28 frutos por planta. 
Tabela 24. Resumo da análise de variância para número de frutos em função de níveis de salinidade e manejo da fertirrigação para o solo franco-argiloso

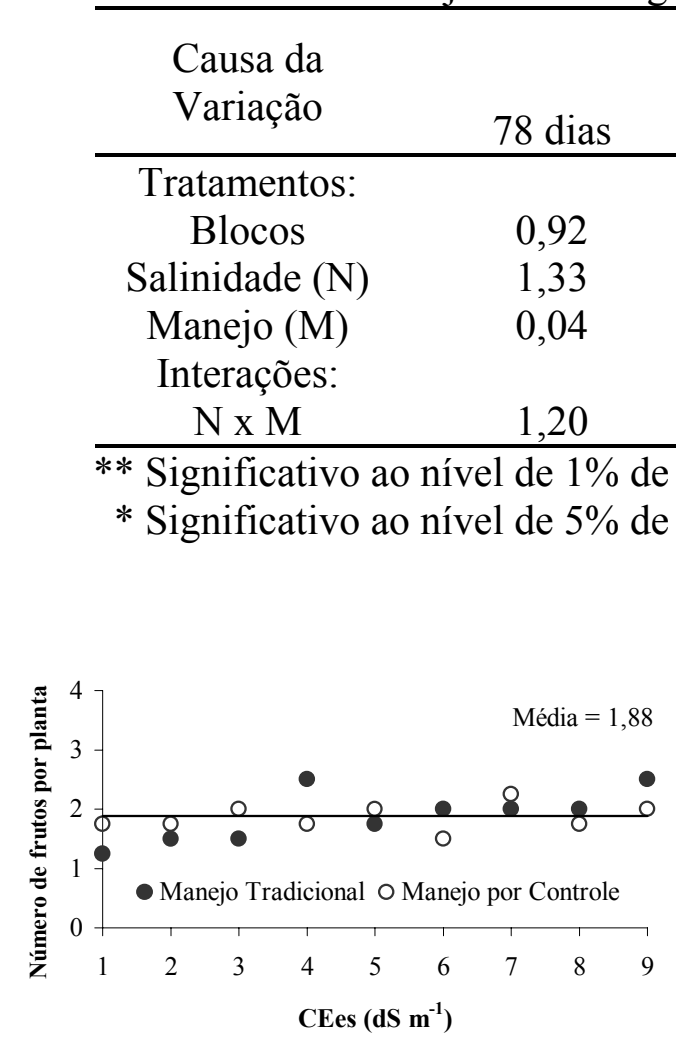

(A)
Estatística F

Número de Frutos 114 dias

2,75

1,69

2,43

0,86
153 dias

\begin{tabular}{c}
$125,82 * *$ \\
0,87 \\
0,33 \\
0,48 \\
\hline
\end{tabular}

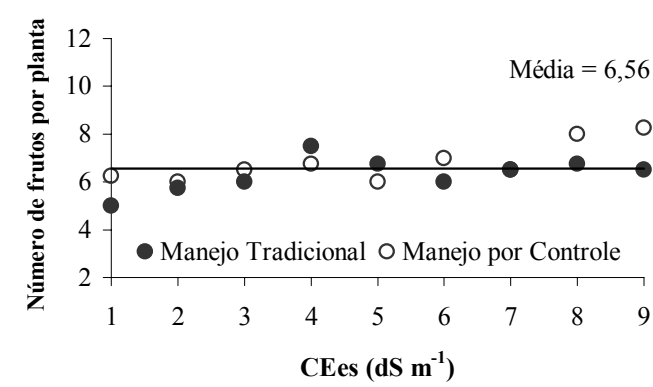

(B)

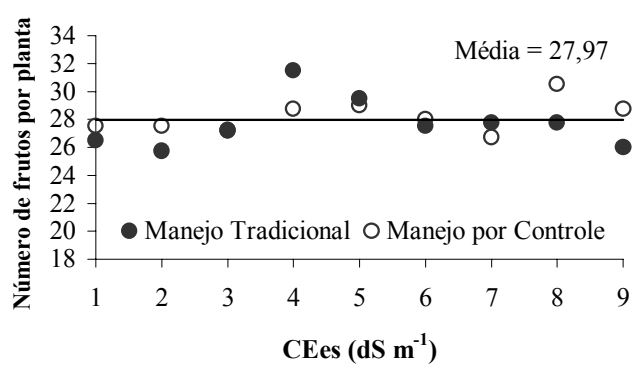

(C)

Figura 49 - Diagrama de dispersão e equação de ajuste para o solo franco-argiloso entre o número de frutos aos: (A) 78 DAT, (B) 114 DAT e (C) 153 DAT para os diferentes manejos de fertirrigação e a salinidade inicial do solo

Na Figura 49 estão apresentados os valores médios do número de frutos por planta em função da salinidade inicial do solo franco-argiloso. A média para as análises realizadas aos 78 DAT, 114 DAT e 153 DAT foram 1,88; 6,56 e 27,97, respectivamente para os diferentes níveis de salinidade e manejo da fertirrigação. 


\subsubsection{Porcentagem de matéria seca e espessura de casca dos frutos}

Apenas a variável espessura de casca foi influenciada pela salinidade inicial do solo ao nível de $1 \%$ pelo teste de F. Entretanto o tipo de solo teve efeito significativo ao nível de 5\% na porcentagem de matéria seca de frutos e na espessura de casca. A variável material seca de fruto diferiu a 5\% em função dos manejos utilizados. A interação entre manejo,solo e salinidade do solo foi significativa a 5\% pelo teste de $\mathrm{F}$ para a variável espessura de casca (Tabela 25).

Tabela 25. Resumo da análise de variância para porcentagem de matéria seca e espessura de casca de frutos em função de níveis de salinidade, para diferentes tipos de solo e manejo

\begin{tabular}{lcc}
\hline Causa da & \multicolumn{2}{c}{ Estatística $\mathrm{F}$} \\
Variação & \%MSF & Espessura de casca \\
& & \\
Tratamentos: & 0,52 \\
Blocos & 0,54 & $6,21^{* *}$ \\
Salinidade (N) & 1,10 & $5,13 *$ \\
Solo (S) & $4,49^{*}$ & 0,33 \\
Manejo (M) & $4,04^{*}$ & 1,24 \\
Interações: & & 1,66 \\
N x S & 1,71 & 0,00 \\
N x M & 0,99 & $2,35 *$ \\
S x M & 0,00 & \\
N x S x M & 1,84 & \\
** Significativo ao nível de $1 \%$ de probabilidade pelo teste $\mathrm{F}$ \\
* Significativo ao nível de $5 \%$ de probabilidade pelo teste $\mathrm{F}$
\end{tabular}

Analisando separadamente o solo franco-arenoso nota-se que apenas a espessura de casca mostrou diferença significativa pelo teste de F, ocasionada pelos níveis de salinidade no solo (Tabela 26). 
Tabela 26. Resumo da análise de variância para porcentagem de matéria seca (MSF) e espessura de casca de frutos em função de níveis de salinidade e manejo da fertirrigação para o solo franco-arenoso

Causa da

Variação
Estatística F

$\% \mathrm{MSF}$

Espessura de casca

\begin{tabular}{ccc}
\hline Tratamentos: & & \\
Blocos & 1,71 & 0,46 \\
Salinidade (N) & 1,83 & $4,28^{* *}$ \\
Manejo (M) & 2,90 & 0,13 \\
Interações: & & \\
N x M & 1,90 & 0,65 \\
\hline
\end{tabular}

** Significativo ao nível de $1 \%$ de probabilidade pelo teste $\mathrm{F}$

* Significativo ao nível de $5 \%$ de probabilidade pelo teste $\mathrm{F}$

Na Figura 50 pode-se verificar os valores médios de porcentagem de matéria seca para os diferentes níveis de salinidade inicial do solo e manejo de fertirrigação, com uma média geral de 7,64\%. O gráfico relativo a espessura de casca mostra uma leve tendência de queda na espessura de casca com o aumento na salinidade inicial do solo para os diferentes manejos da fertirrigação. Apesar de significativo o $\mathrm{R}^{2}$ de 0,58 retrata a dispersão dos valores médios em relação à curva de ajuste.

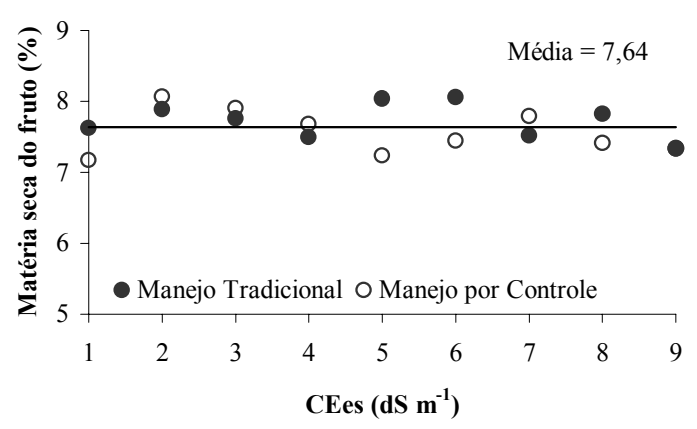

(A)

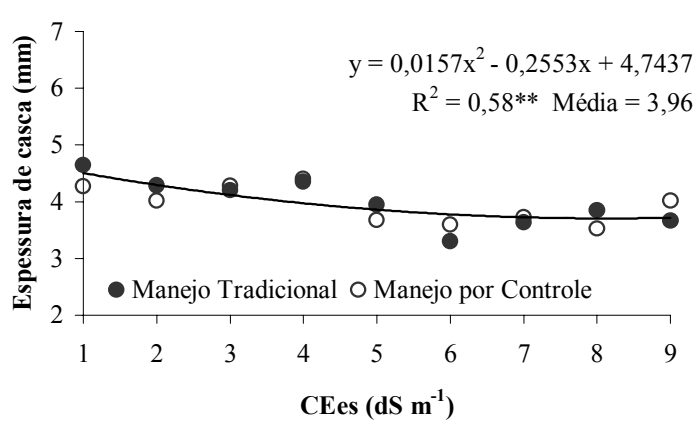

(B)

Figura 50- Diagrama de dispersão e equação de ajuste para o solo franco-arenoso entre: (A) porcentagem de matéria seca e (B) espessura de casca e a salinidade inicial do solo 
Em relação ao solo franco-argiloso apenas a variável espessura de casca diferiu-se em função da salinidade inicial. $\mathrm{O}$ manejo da fertirrigação não interferiu nas duas variáveis analisadas (Tabela 27).

Tabela 27. Resumo da análise de variância para porcentagem de matéria seca e espessura de casca de frutos em função de níveis de salinidade e manejo da fertirrigação para o solo franco-argiloso

\begin{tabular}{ccc}
\hline Causa da & \multicolumn{2}{c}{ Estatística F } \\
Variação & \multicolumn{2}{c}{ Espessura de casca } \\
\hline Tratamentos: & & \\
Blocos & 0,12 & 0,12 \\
Salinidade (N) & 1,45 & $2,76^{*}$ \\
Manejo (M) & 1,89 & 0,21 \\
Interações: & & \\
N x M & 1,40 & 3,71 \\
\hline
\end{tabular}

* Significativo ao nível de $5 \%$ de probabilidade pelo teste $\mathrm{F}$

$\mathrm{Na}$ Figura 51 pode-se observar os dados médios para variável porcentagem de matéria seca, que apresentou uma média geral de 7,47\% para o solo franco-argiloso e a regressão linear para a variável espessura de casca. A correlação do ajuste não foi significativa, entretanto, percebe-se um leve queda da espessura de casca do fruto com o incremento da salinidade inicial do solo e uma média de 3,80 $\mathrm{mm}$.

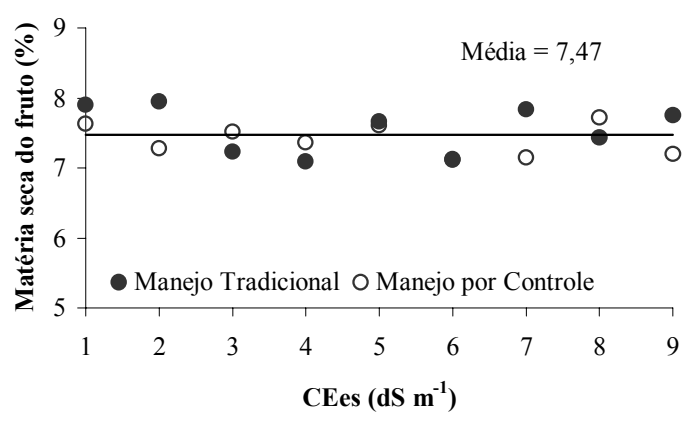

(A)

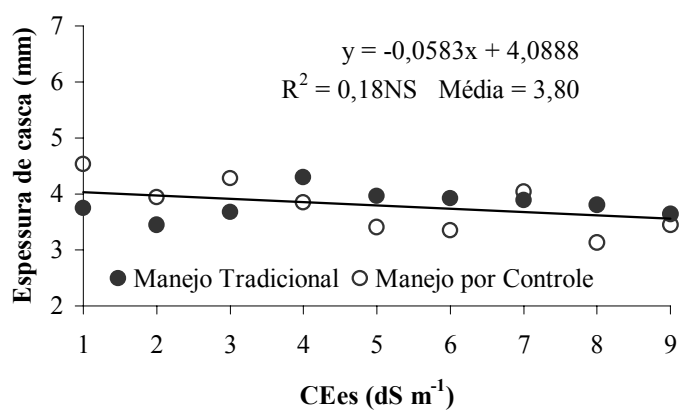

(B)

Figura 51 - Diagrama de dispersão e equação de ajuste para o solo franco-argiloso entre: (A) porcentagem de matéria seca e (B) espessura de casca e a salinidade inicial do solo 


\subsubsection{Diâmetro e comprimento médio dos frutos}

A análise de variância, cujo resumo encontra-se na Tabela 28, evidencia que as variáveis diâmetro e comprimento médio de frutos diferiram significativamente em função dos fatores salinidade inicial e solo. Nota-se ainda que o manejo da fertirrigação influenciou a variável comprimento médio de frutos. Todavia, as interações foram significativas em sua maioria, mostrando assim o efeito combinado entre os fatores. Para maior compreensão estudaremos as variáveis para cada tipo de solo.

Tabela 28. Resumo da análise de variância para diâmetro e comprimento médios de fruto em função de níveis de salinidade, para diferentes tipos de solo e manejo

\begin{tabular}{ccc}
\hline Causa da & \multicolumn{2}{c}{ Estatística $\mathrm{F}$} \\
Variação & Diâmetro & Comprimento \\
\hline Tratamentos: & & \\
Blocos & 1,47 & $4,47^{* *}$ \\
Salinidade (N) & $28,24^{* *}$ & $82,34^{* *}$ \\
Solo (S) & $116,52^{* *}$ & $1458,45^{* *}$ \\
Manejo (M) & 0,216 & $15,01^{* *}$ \\
Interações: & & \\
N x S & $26,79^{* *}$ & $36,12^{* *}$ \\
N x M & $13,81^{* *}$ & $37,21^{* *}$ \\
S x M & 8,32 & $25,00^{* *}$ \\
N x S x M & $19,00^{* *}$ & $18,53^{* *}$ \\
\hline ** Significativo ao nível de $1 \%$ de probabilidade pelo teste F
\end{tabular}

** Significativo ao nível de $1 \%$ de probabilidade pelo teste $\mathrm{F}$

$\mathrm{Na}$ Tabela 29 pode-se verificar que para o solo franco-arenoso as variáveis diâmetro e comprimento de frutos diferiram ao nível de $1 \%$ pelo teste de $\mathrm{F}$. A salinidade do solo, o manejo da fertirrigação, bem como as interações entre eles proporcionaram diferenças significativas. 
Tabela 29. Resumo da análise de variância para diâmetro e comprimento médios de fruto em função de níveis de salinidade e manejo da fertirrigação para o solo franco-arenoso

\begin{tabular}{ccc}
\hline Causa da & \multicolumn{2}{c}{ Estatística $\mathrm{F}$} \\
Variação & Diâmetro & Comprimento \\
\hline Tratamentos: & 1,67 & 1,30 \\
Blocos & $31,94^{* *}$ & $47,63^{* *}$ \\
Salinidade (N) & $4,99^{* *}$ & $27,80^{* *}$ \\
Manejo (M) & & \\
Interações: & $22,35^{* *}$ & $33,34^{* *}$ \\
N x M & & \\
\hline
\end{tabular}

** Significativo ao nível de $1 \%$ de probabilidade pelo teste $\mathrm{F}$

O diâmetro de fruto foi afetado pela salinidade do solo mostrando um ajuste polinomial quadrático decrescente em relação ao manejo tradicional. $\mathrm{O}$ valor de $\mathrm{R}^{2}$ foi significativo e igual à 0,74 , ou seja os valores médios do diâmetro do fruto apresentam baixa dispersão em relação a curva de ajuste. Para o manejo controlado o diâmetro de fruto não apresentou uma tendência definida e obteve uma média de 49,14 $\mathrm{mm}$ (Figura 52). O comprimento de fruto foi reduzido com o aumento da salinidade do solo para o manejo tradicional, todavia para o manejo controlado não foi verificada uma tendência. No diagrama de dispersão (D) estão apresentados os valores médios em função da salinidade, a média geral para manejo controlado foi de 75,97 mm. 


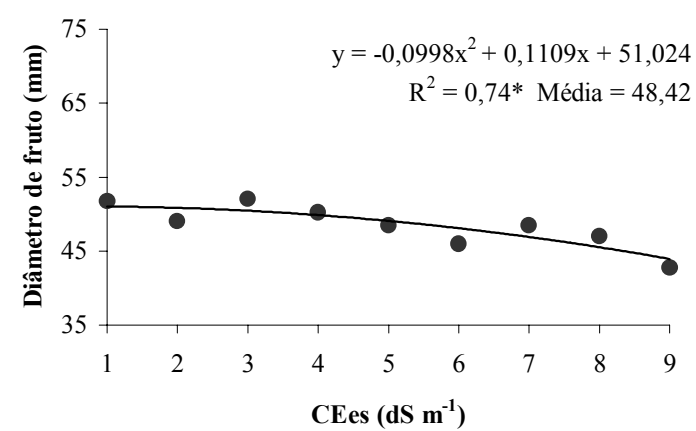

(A)

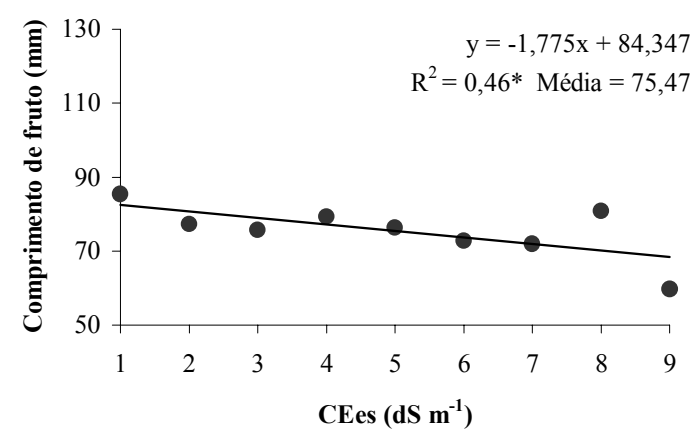

(C)

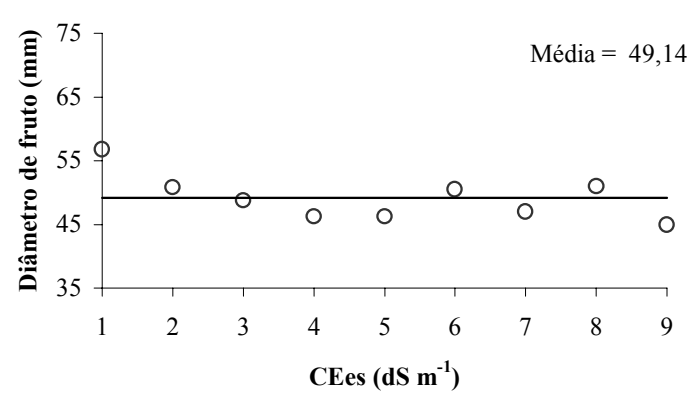

(B)

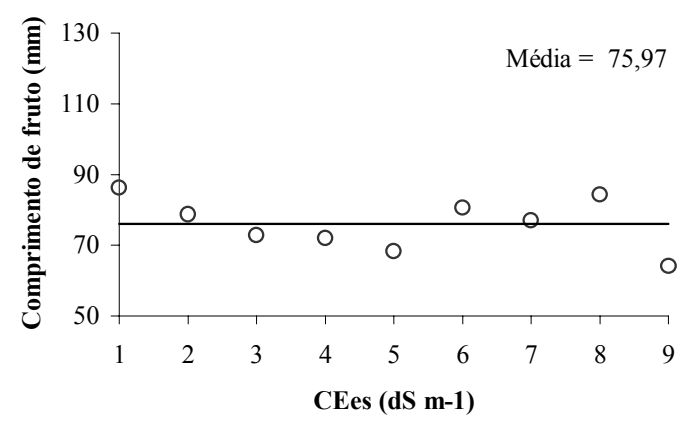

(D)

Figura 52 - Diagrama de dispersão e equação de ajuste para o solo franco-arenoso entre: (A) diâmetro de frutos com o manejo tradicional da fertirrigação, (B) diâmetro de frutos com o manejo controlado da fertirrigação, (C) comprimento de frutos com o manejo tradicional da fertirrigação, (D) comprimento de frutos com o manejo controlado da fertirrigação e a salinidade inicial do solo

Para o solo franco-argiloso, o diâmetro e o comprimento médio dos frutos foram influenciados significativamente pela salinidade do solo (Tabela 30). A tendência polinomial quadrática das regressões apresentadas na Figura 53 indica que a salinidade do solo proporciona um aumento no tamanho do fruto até um máximo (próximo a salinidade inicial de $4 \mathrm{dS} \mathrm{m}^{-1}$ ). A partir desse valor o tamanho o fruto decresce com o incremento da salinidade. Entretanto os valores de $\mathrm{R}^{2}$ de 0,17 e 0,38 demonstram uma alta dispersão dos pontos em relação a reta de ajuste.

Medeiros (1998) encontrou para comprimento de fruto valores médios de $121 \mathrm{~mm}$, superior ao encontrado no presente experimento, esse fato pode ser atribuído as características dos híbridos cultivados. 
Tabela 30.Resumo da análise de variância para para diâmetro e comprimento médios de fruto em função de níveis de salinidade e manejo da fertirrigação para o solo franco-argiloso

\begin{tabular}{ccc}
\hline Causa da & \multicolumn{2}{c}{ Estatística F } \\
Variação & Diâmetro & Comprimento \\
\hline Tratamentos: & & \\
Blocos & $4,15^{*}$ & $5,51^{* *}$ \\
Salinidade (N) & $26,13^{* *}$ & $84,72^{* *}$ \\
Manejo (M) & 3,99 & 7,38 \\
Interações: & & \\
N x M & 10,49 & $14,11^{* *}$ \\
\hline
\end{tabular}

** Significativo ao nível de $1 \%$ de probabilidade pelo teste $\mathrm{F}$

* Significativo ao nível de $5 \%$ de probabilidade pelo teste $\mathrm{F}$

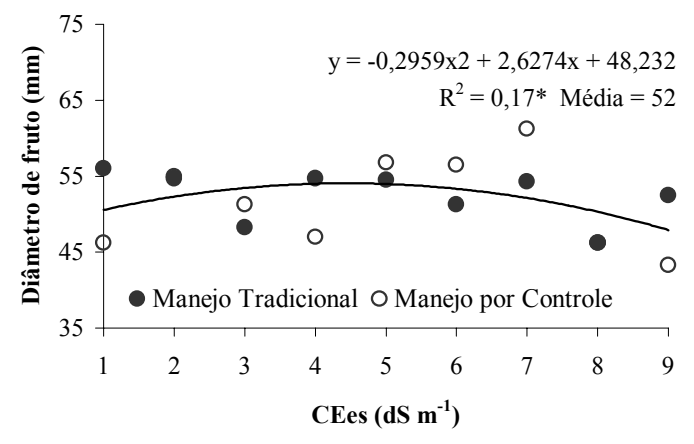

(A)

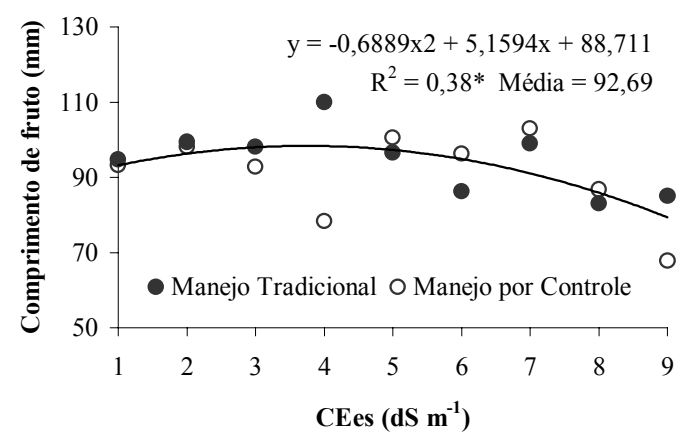

(B)

Figura 53 - Diagrama de dispersão e equação de ajuste para o solo franco-argiloso entre: (A) diâmetro de frutos e (B) comprimento de frutos para ambos os manejos de fertirrigação e a salinidade inicial do solo

\subsubsection{Variáveis de qualidade e teores de macronutrientes nos frutos}

A variáveis relacionadas à qualidade do fruto avaliadas foram a acidez total titulável e os sólidos solúveis; as mesmas foram realizadas em amostras compostas para cada tratamento. Na Figura 54 estão apresentados os valores de sólidos solúveis determinados para os diferentes tratamentos. Os sólidos solúveis representados pelo ${ }^{\circ}$ Brix expressam os açúcares presentes nos frutos. Os resultados obtidos numericamente não apresentaram valores que permitam ser verificadas diferenças entre os tratamentos 
que possuem uma média de 5,56; resultados semelhantes foram obtidos por Nanetti (2001)

No diagrama de blocos (B) da Figura 54 os valores de acidez total titulável são expressos em \% de ácido cítrico. Essa variável tem influência principalmente no sabor dos frutos. Os resultados obtidos não demonstram diferenças numéricas consideráveis e conseqüentemente os tratamentos parecem não ter influência sobre a variável, entretanto, à média dos valores igual à $0,10 \%$ é inferior a média apresentada por Nanetti (2001).

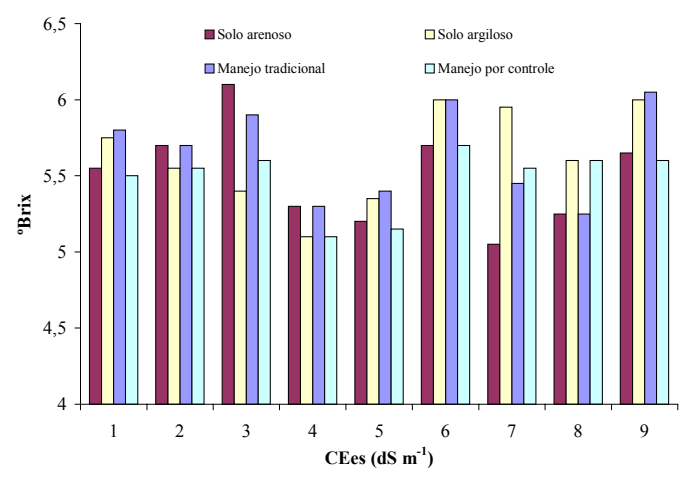

(A)

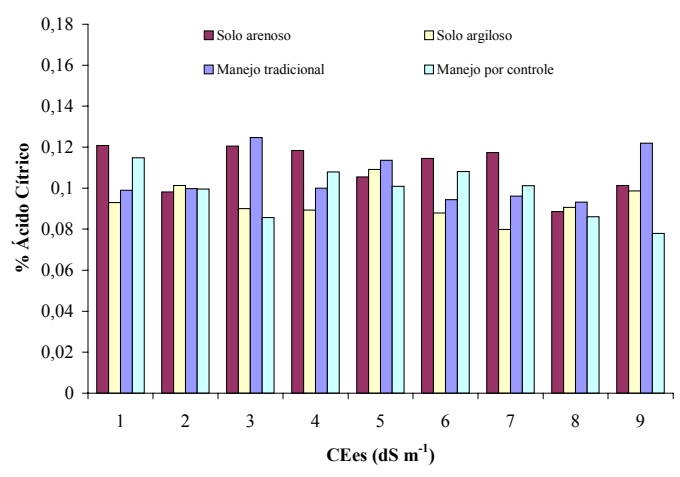

(B)

Figura 54 - Quantificação do: (A) sólidos solúveis e (B) acidez titulável para os frutos dos diferentes tratamentos

$\mathrm{Na}$ Figura 55 pode-se observar os valores de macronutrientes presentes nos frutos e expresso em termos de porcentagem de matéria seca. As análises foram realizadas em amostras compostas para todos os tratamentos. Os valores determinados encontram-se em concordância pelos valores obtidos por Villas Bôas (2001). 


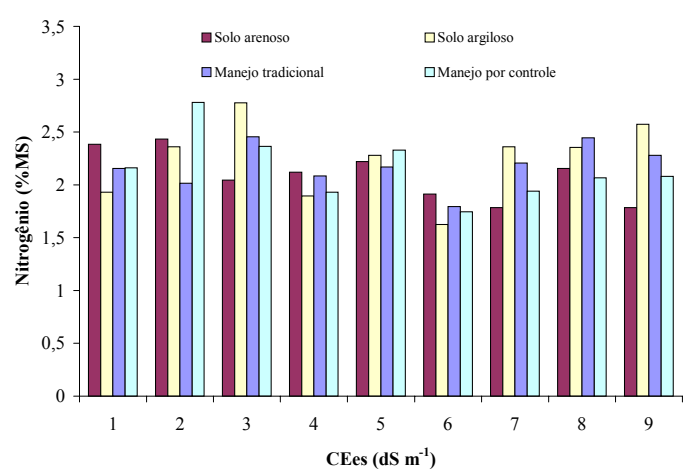

(A)

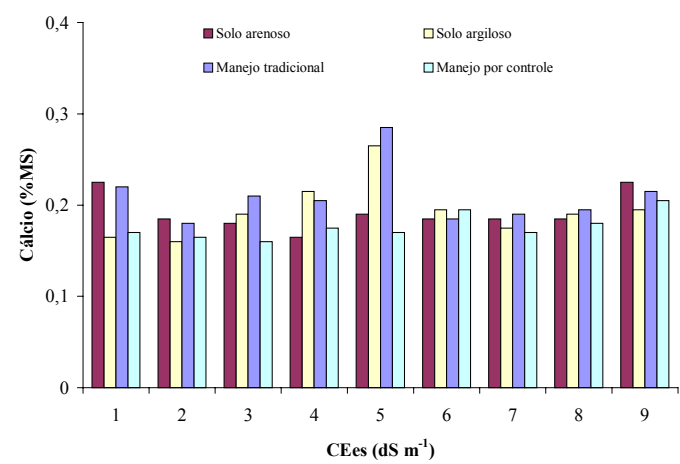

(C)

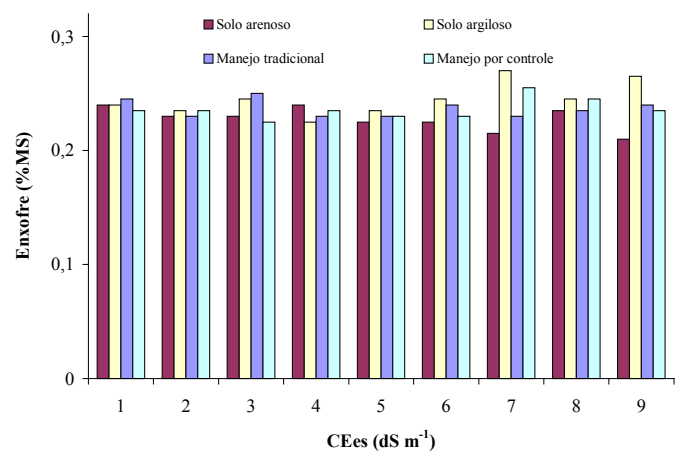

(E)

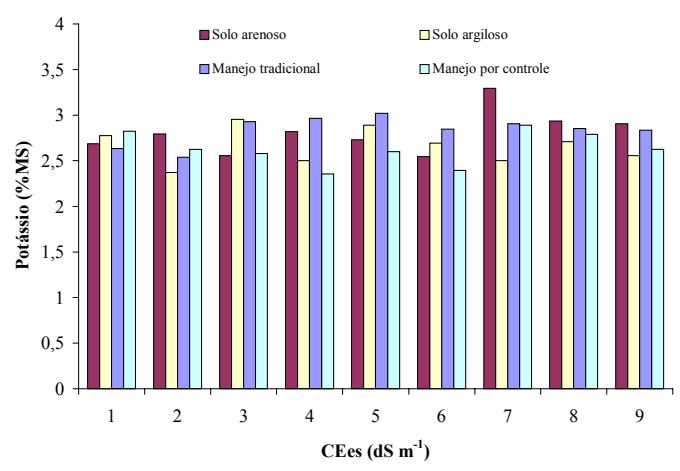

(B)

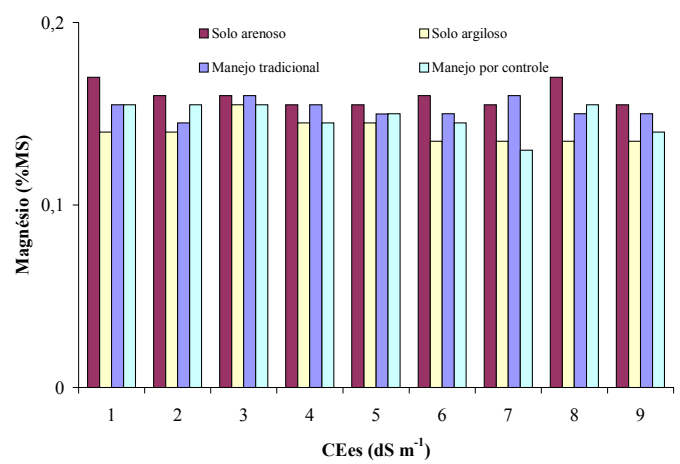

(D)

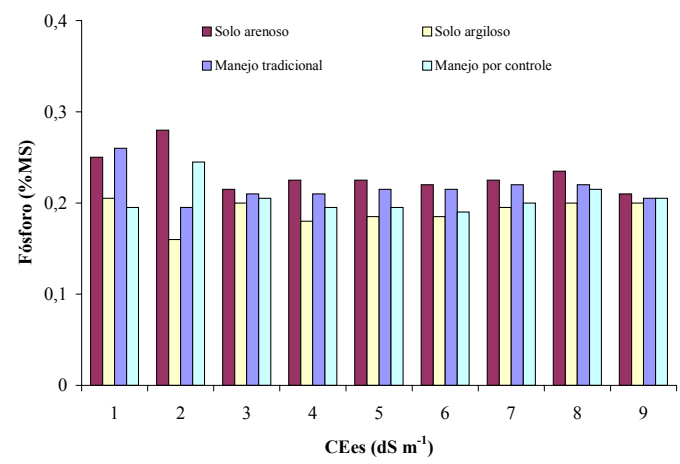

(F)

Figura 55 - Concentração dos macronutrientes: (A) nitrogênio, (B) potássio, (C) cálcio, (D) magnésio, $(\mathrm{E})$ enxofre e $(\mathrm{F})$ fósforo nos frutos dos diferentes tratamentos

Para todos os íons não se notam diferenças numéricas marcantes. Assim, pode-se afirmar que os diferentes tratamentos não influenciaram consideravelmente a concentração de nutrientes nos frutos. Possivelmente, a amostragem composta interferiu nos resultados obtidos e a prática de aplicação de defensivos e nutrientes via foliar pode ter influenciado na concentração dos macronutrientes nos frutos. 


\subsubsection{Teores de potássio e nitrato na seiva da planta}

Os teores de nitrato e potássio na seiva da planta diferiram significativamente ao nível de 5\% pelo teste de $\mathrm{F}$ em função da salinidade inicial, do tipo de solo e do manejo da fertirrigação. As interações também foram significativas, sugerindo o efeito combinado entre os fatores estudados. Assim torna-se necessário avaliar o efeito de forma separada para os diferentes tipos de solo (Tabela 31).

Tabela 31. Resumo da análise de variância para $\mathrm{K}$ e $\mathrm{NO}_{3}$ na seiva em função de níveis de salinidade, para diferentes tipos de solo e manejo

\begin{tabular}{|c|c|c|}
\hline \multirow{2}{*}{$\begin{array}{l}\text { Causa da } \\
\text { Variação }\end{array}$} & \multicolumn{2}{|c|}{ Estatística F } \\
\hline & $\mathrm{K}$ na seiva & $\mathrm{NO}_{3}$ na seiva \\
\hline \multicolumn{3}{|l|}{ Tratamentos: } \\
\hline Blocos & $7,81 * *$ & 0,486 \\
\hline Salinidade $(\mathrm{N})$ & $63,11 * *$ & $22,49 * *$ \\
\hline Solo (S) & $19,46^{* *}$ & $13,53 * *$ \\
\hline Manejo (M) & $5,00 *$ & $11,71 * *$ \\
\hline \multicolumn{3}{|l|}{ Interações: } \\
\hline $\mathrm{N} \times \mathrm{S}$ & $19,04 * *$ & $27,79 * *$ \\
\hline $\mathrm{N} \times \mathrm{M}$ & $31,26 * *$ & $13,74 * *$ \\
\hline $\mathrm{S} \times \mathrm{M}$ & $280,98 * *$ & $7,15 * *$ \\
\hline $\mathrm{N} \times \mathrm{S} \times \mathrm{M}$ & $43,27 * *$ & $22,53 * *$ \\
\hline
\end{tabular}

** Significativo ao nível de $1 \%$ de probabilidade pelo teste $\mathrm{F}$

* Significativo ao nível de $5 \%$ de probabilidade pelo teste $\mathrm{F}$

A concentração de potássio na seiva diferiu significativamente para o solo franco-arenoso para todos os fatores analisados, inclusive em relação a sua interação. Para a concentração de nitrato na seiva da planta o fator manejo da fertirrigação não interferiu significativamente (Tabela 32). 
Tabela 32. Resumo da análise de variância para $\mathrm{K}$ e $\mathrm{NO}_{3}$ na seiva em função de níveis de salinidade e manejo da fertirrigação para o solo franco-arenoso

\begin{tabular}{ccc} 
Causa da & \multicolumn{2}{c}{ Estatística $\mathrm{F}$} \\
Variação & K na seiva & $\mathrm{NO}_{3}$ na seiva \\
\hline Tratamentos: & $4,31 * *$ & \\
Blocos & $48,50 * *$ & 0,845 \\
Salinidade $(\mathrm{N})$ & $151,53 * *$ & $39,19 * *$ \\
Manejo $(\mathrm{M})$ & & 0,32 \\
Interações: & $24,44 * *$ & $24,39 * *$ \\
N x M & * &
\end{tabular}

** Significativo ao nível de $1 \%$ de probabilidade pelo teste $\mathrm{F}$

Nos diagramas de dispersão referentes a Figura 56 pode-se verificar que para o solo franco-arenoso, no manejo da fertirrigação controlado, o ajuste linear apresenta uma tendência de aumento do teor de potássio na seiva à medida que a salinidade inicial do solo é incrementada. Entretanto os valores médios apresentam-se próximos a 200 mmol $_{\mathrm{c}} \mathrm{L}^{-1}$ para os dois manejos estudados. O teor de nitrato apesar de apresentar diferença significativa pelo teste de F não mostrou na análise de regressão uma tendência, isso pode ser atribuído a dispersão dos pontos para os diferentes manejos. O valor médio de nitrato para os tratamentos estudados foi de 135,16 $\operatorname{mmol}_{\mathrm{c}} \mathrm{L}^{-1}$. 


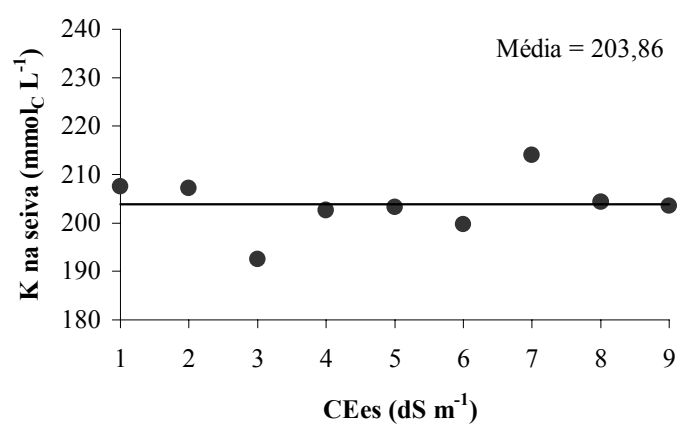

(A)

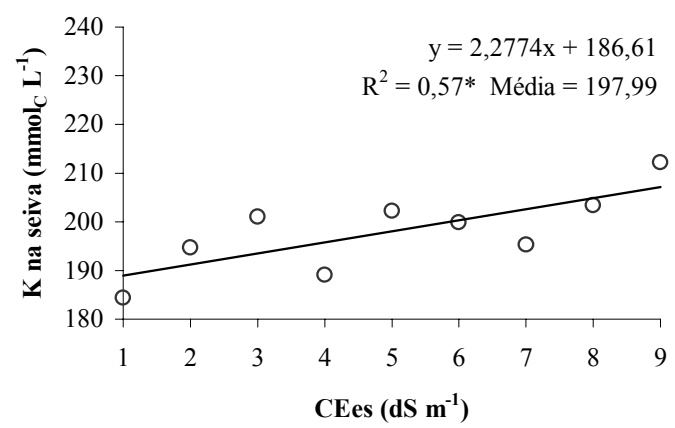

(B)

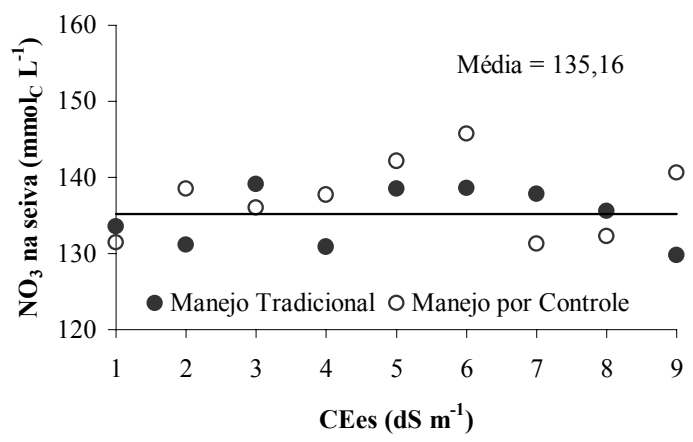

(C)

Figura 56 - Diagrama de dispersão e equação de ajuste para o solo franco-arenoso entre: (A) concentração de potássio na seiva com manejo tradicional da fertirrigação, (B) concentração de potássio na seiva com manejo controlado da fertirrigação e (C) concentração de nitrato na seiva para ambos os manejos de fertirrigação e a salinidade inicial do solo

$\mathrm{Na}$ Tabela 33 está exposto um resumo da análise de variância para concentração de potássio e de nitrato na seiva da planta para o solo franco-argiloso. Os valores de $\mathrm{F}$ mostram que ambas as variáveis apresentam diferenças significativas para a salinidade inicial, o manejo da fertirrigação bem como do manejo entre esses fatores.

Na Figura 57 pode-se observar que os níveis de potássio na seiva aumentaram em função da salinidade do solo apenas para o manejo da fertirrigação controlado, mantendo se constante para o manejo tradicional e com médias gerais de $195,31 \mathrm{mmol}_{\mathrm{c}} \mathrm{L}^{-1}$ e 202,98 $\mathrm{mmol}_{\mathrm{c}} \mathrm{L}^{-1}$, respectivamente. 
Tabela 33. Resumo da análise de variância para $\mathrm{K}$ e $\mathrm{NO}_{3}$ na seiva em função de níveis de salinidade e manejo da fertirrigação para o solo franco-argiloso

Causa da

Estatística F

Variação

$\mathrm{NO}_{3}$ na seiva

\begin{tabular}{ccc}
\hline Tratamentos: & & \\
Blocos & $3,45^{*}$ & 0,49 \\
Salinidade (N) & $28,61^{* *}$ & $14,03^{* *}$ \\
Manejo (M) & $123,69^{* *}$ & $16,39 * *$ \\
Interações: & & \\
N x M & $53,26 * *$ & $12,86^{* *}$
\end{tabular}

** Significativo ao nível de $1 \%$ de probabilidade pelo teste $\mathrm{F}$

* Significativo ao nível de $5 \%$ de probabilidade pelo teste $\mathrm{F}$

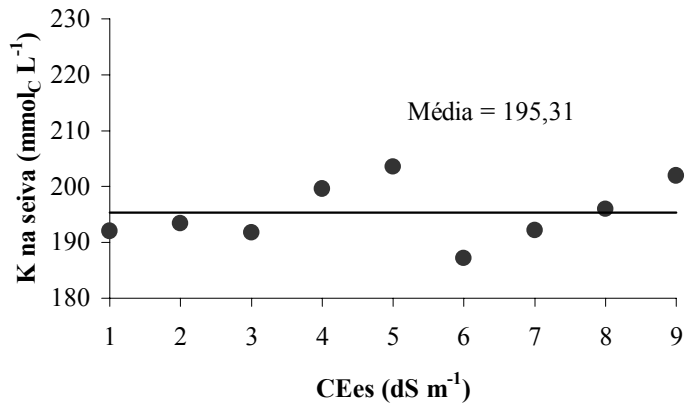

(A)

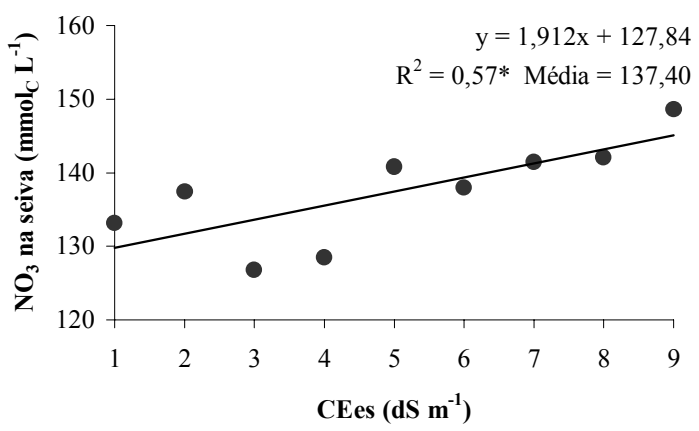

(C)

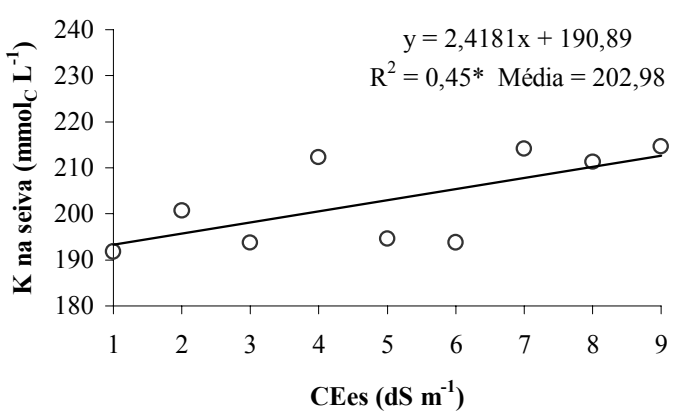

(B)

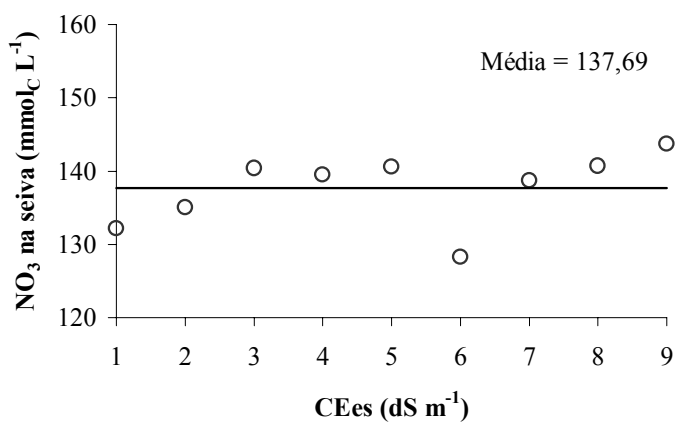

(D)

Figura 57 - Diagrama de dispersão e equação de ajuste para o solo franco-argiloso entre: (A) concentração de potássio na seiva com manejo tradicional da fertirrigação, (B) concentração de potássio na seiva com manejo controlado da fertirrigação e (C) concentração de nitrato na seiva com manejo tradicional da fertirrigação e (D) concentração de nitrato na seiva com manejo controlado da fertirrigação e a salinidade inicial do solo 


\subsubsection{Comparação entre os valores de potássio e nitrato determinados em laboratório e em testes rápidos}

As determinações nas concentrações de potássio e nitrato na solução do solo realizadas em laboratório por meio de fotometria de chamas e potenciometria, respectivamente, e em campo por meio de testes rápidos são comparadas na Figura 58. O teste rápido para potássio superestimou os valores determinados por fotometria de chamas em $27 \%$. O valor de $\mathrm{D}$ igual à 0,11 mostra os métodos diferem-se entre si e necessitam de um ajuste prévio a partir, por exemplo, de calibrações. Entretanto, o teste de Willmott apresentou um índice de concordância de 0,95 que significa que os valores não mostraram grande dispersão em relação a reta 1:1. O valor do coeficiente de determinação de 0,92 retrata a precisão em relação ao método analisado.

Os valores de concentração de nitrato na solução determinados pelo teste rápido subestimaram o medido em laboratório em 33\% com uma precisão de $77 \%$. Para esse íon os valores de D calculado de 0,17 quando comparado com o tabelado indica que os métodos diferem entre si e que necessitam de ajuste prévio. $\mathrm{O}$ índice de concordância de 0,86 reforça a afirmação anterior.

Todavia a rapidez e a praticidade nas determinações permite-nos avaliar com certa precisão a concentração de potássio e nitrato na solução do solo em situ. 


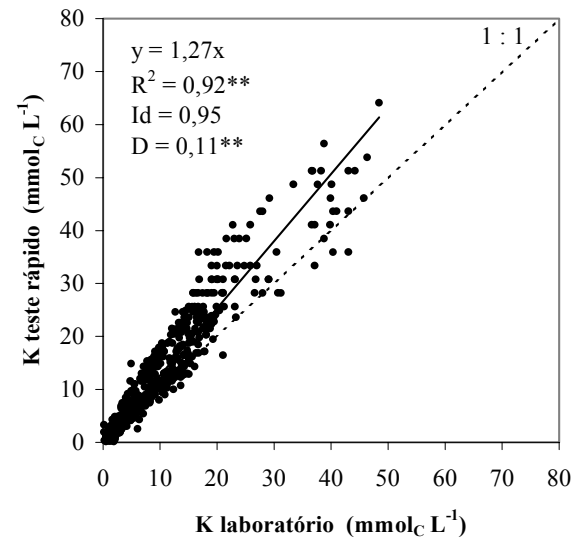

(A)

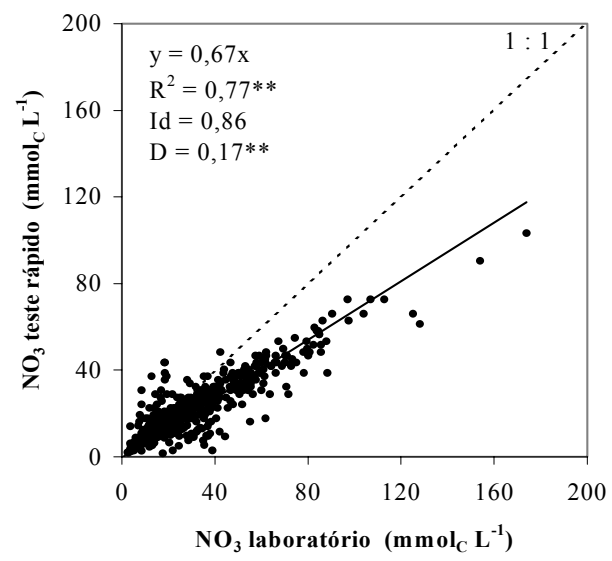

(B)

Figura 58 - Relação entre os valores de: (A) potássio e (B) nitrato determinados em laboratório e em campo por meio de testes rápidos

\subsubsection{Demanda hídrica da cultura sob condições salinas}

Assim como a variáveis de rendimento e as vegetativas o consumo hídrico total apresentou uma tendência diferenciada para os diferentes solos utilizados quando relacionados com a salinidade do solo (Figura 59). No solo franco-arenoso a curva ajustada foi um modelo polinomial quadrático, semelhante ao ajuste da variável rendimento. Observou-se um decréscimo do consumo com o incremento da salinidade do solo. Entretanto o consumo hídrico das plantas cultivadas no solo franco-argiloso não diferiu sensivelmente em função do incremento da salinidade. O estudo apresentado a seguir enfatiza apenas a redução na absorção da água pelo solo franco-arenoso.

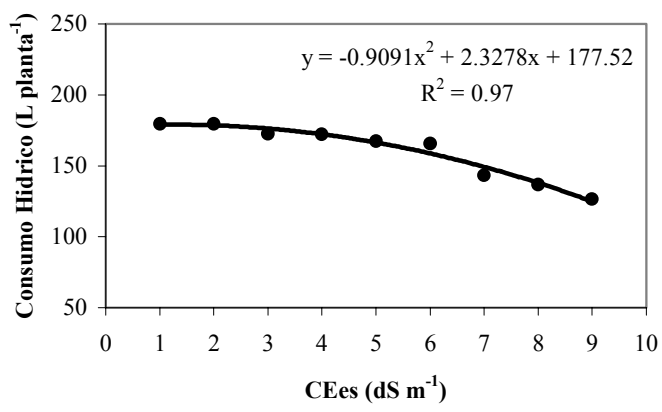

(A)

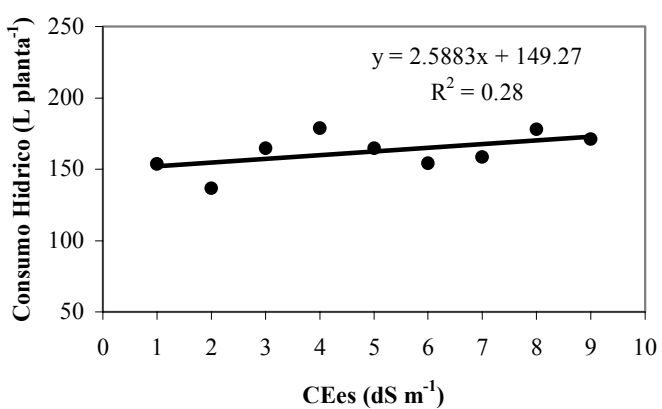

(B)

Figura 59 - Consumo hídrico médio para os solos: (A) franco-arenoso e (B) francoargiloso 
Pode-se observar pela Figura 60 os valores de Kc nas diversas fases fenológicas da cultura. Nota-se que os valores determinados aproximam-se dos valores apresentados por Doorenbos \& Kassam (1979) e Medeiros (1998). Entretanto as diferenças podem ser atribuídas às condições locais, variedade e período de cultivo. Os valores encontrados por Doorenbos \& Kassam (1979) são relativos a cultivos em campo aberto. $\mathrm{O}$ valor encontrado para fase final concorda com o valor citado pela FAO, enquanto que o valor proposto por Medeiros (1998) apresenta uma discrepância acentuada, causada possivelmente por um sombreamento do mini-tanque.

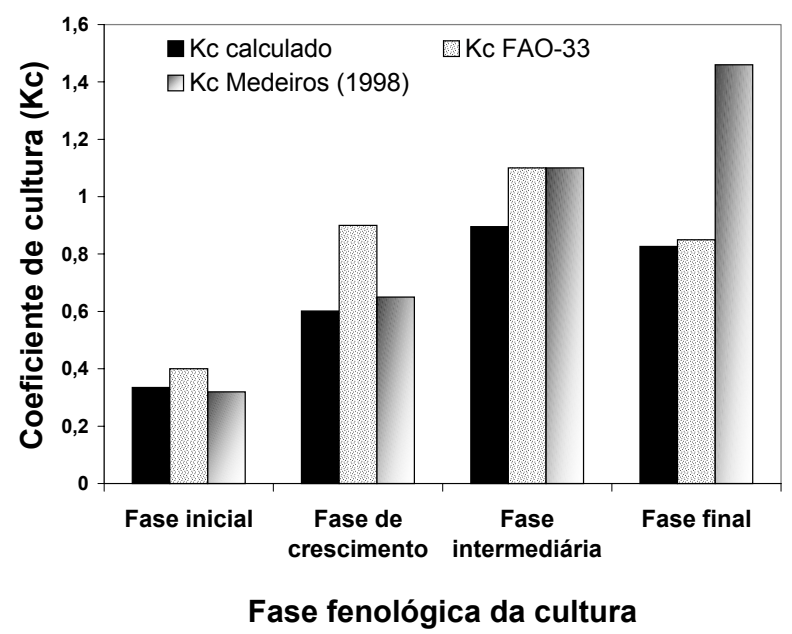

Figura 60 - Coeficientes da cultura para diferentes fases fenológicas, calculados para o solo franco-arenoso

O consumo hídrico para condições não salinas correspondeu a uma evapotranspiração total próxima de $400 \mathrm{~mm}$ durante os 153 DAT. Doorenbos \& Kassam (1979) apresentam um consumo total entre 600 e $900 \mathrm{~mm}$. O menor consumo encontrado deve-se ao fato de que, em condições protegidas, a taxa de evapotranspiração é menor, como citado por Monteiro et al. (1985).

Percebe-se pelo gráfico A da Figura 61 que os valores de evapotranspiração de referência $(\mathrm{ETL})$ foram crescentes durante o ciclo, visto que o experimento teve início na primavera e final no verão. Entretanto, os valores estimados pelo modelo da radiação global apresentaram comportamento inverso, provavelmente durante a fase inicial o fator radiação solar teve maior influência em relação aos outros 
fatores contribuintes para evapotranspiração. A estimativa pelo modelo da radiação superou a estimativa por Penmam-Montheith ao longo do ciclo, possivelmente isso ocorreu em virtude do modelo de Penmam-Montheith levar em consideração o efeito do vento, o qual torna-se insignificante sob ambiente protegido. A evapotranspiração da cultura e real, ou seja, influenciada pela salinização do solo franco-franco arenoso, foi crescente ao longo do ciclo fenológico da cultura. A evapotranspiração real apresentou decréscimo em função do incremento da salinidade do solo, destacando-se a fase de crescimento, onde a redução do consumo apresentou-se mais acentuada. Os coeficientes da salinidade apresentados na Tabela 34 sugerem uma interferência na evapotranspiração real ocasionada por uma redução no potencial osmótico. Nota-se que em média até o nível de salinidade do solo de $4 \mathrm{dS} \mathrm{m}^{-1}$ ocorreu um decréscimo de apenas $3 \%$ no consumo hídrico quando comparado com a evapotranspiração em condição não salina. A partir do nível de $5 \mathrm{dS} \mathrm{m}^{-1}$ até a condição mais salina $\left(9 \mathrm{dS} \mathrm{m}^{-1}\right)$ houve uma redução no consumo de 6 a 28\%, respectivamente. Os valores de temperaturas máxima e mínima ao longo do ciclo da cultura apresentaram-se dentro dos limites citados por Villas Bôas (2001) como não prejudiciais, $15^{\circ} \mathrm{C}$ para mínima e $53^{\circ} \mathrm{C}$ para máxima (Figura $61 \mathrm{~B}$ ).

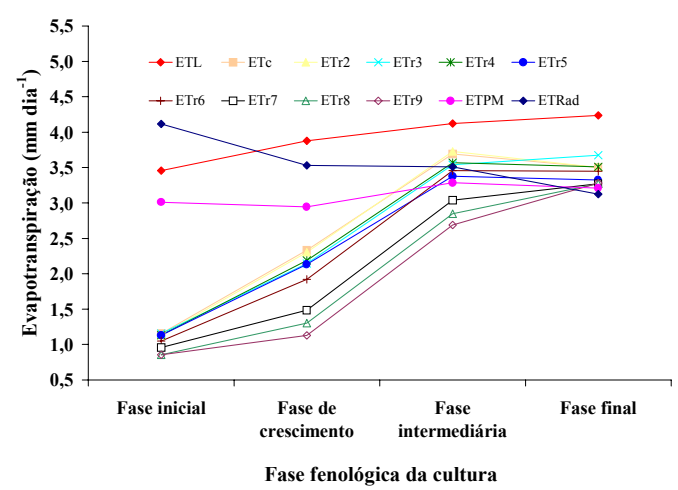

(A)

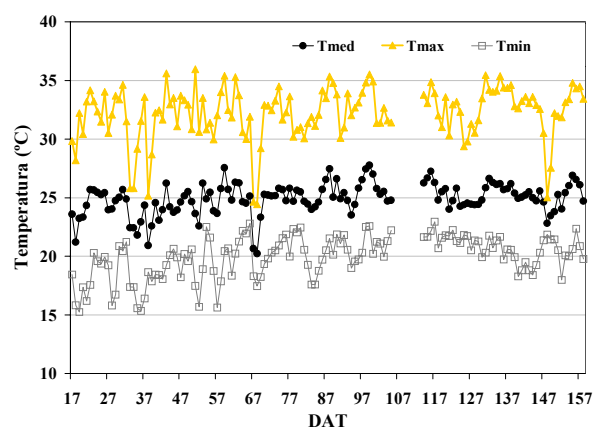

(B)

Figura 61 - (A) Evapotranspiração de referência pelo tanque evaporimétrico (ETL), por Penman-Montheith (ETPM) e pelo método da radiação (ETRad); da cultura (Etc) e real (Etr) para os diferentes níveis de salinidade do solo francoarenoso e (B) temperatura máxima, média e mínima ao longo do ciclo 
Durante a fase de crescimento, a cultura apresentou maior sensibilidade à condição salina, e consequentemente a redução na ETr mostrou-se mais acentuada com o incremento da salinidade do solo atingindo um decréscimo de até $52 \%$ no consumo para a condição mais salina.

Tabela 34. Coeficientes de salinidade para os diferentes valores de condutividade elétrica do extrato de saturação do solo franco-arenoso e fases fenológicas da cultura

\begin{tabular}{cccccc}
\hline Salinidade do solo & \multicolumn{4}{c}{ Coeficiente de salinidade (Ks) } \\
CEes $\left(\mathrm{dS} \mathrm{m}^{-1}\right)$ & Fase inicial & Fase de crescimento & Fase intermediária & Fase final & Médio \\
\hline 1 & 1,00 & 1,00 & 1,00 & 1,00 & 1,00 \\
2 & 0,98 & 0,99 & 1,00 & 1,00 & 0,99 \\
3 & 1,00 & 0,92 & 0,96 & 1,00 & 0,97 \\
4 & 0,98 & 0,94 & 0,97 & 1,00 & 0,97 \\
5 & 0,98 & 0,91 & 0,91 & 0,95 & 0,94 \\
6 & 0,91 & 0,82 & 0,94 & 0,99 & 0,91 \\
7 & 0,83 & 0,64 & 0,82 & 0,94 & 0,81 \\
8 & 0,74 & 0,56 & 0,77 & 0,94 & 0,75 \\
9 & 0,74 & 0,48 & 0,73 & 0,94 & 0,72 \\
\hline
\end{tabular}

\subsubsection{Tolerância da cultura do pimentão à salinidade}

Na Figura 62 é apresentada uma curva de regressão, que representa a tolerância do híbrido de pimentão "Elisa" à salinidade no solo franco arenoso, avaliada em função dos valores de condutividade elétrica do extrato de saturação (CEes) correspondente ao início da fase de floração. A tolerância em relação a salinidade do solo franco-argiloso não será estudada em virtude da ausência de resposta das variáveis em função da salinidade inicial com tendência de acréscimo do rendimento como o incremento da salinidade inicial do solo, ocasionado possivelmente pela distribuição de sais nos vasos, como discutido anteriormente.

Verifica-se que o modelo linear se adaptou bem aos pontos obtidos, revelando um coeficiente de determinação igual a 0,93. Pode-se notar que os dados experimentais indicaram uma tolerância para a cultura do pimentão superior àquela preconizada na literatura, com valor de salinidade limiar de $3,58 \mathrm{dS} \mathrm{m}^{-1}$, essa maior tolerância deveu-se a uma queda de produção de apenas $8,56 \%$ contra os $14 \%$ citados 
por Maas \& Hoffman (1977), os quais encontraram uma salinidade limiar de $1,50 \mathrm{dS} \mathrm{m}^{-1}$.

A diferença pode ser devida às condições locais e ambientais de onde foi desenvolvido o experimento e principalmente ao sistema e manejo de irrigação utilizado. Segundo Rhoades et al. (2000), a irrigação por gotejamento associada a uma freqüência elevada reduz os efeitos da salinidade sob a cultura, visto que, os sais tendem a ser deslocados para a periferia do bulbo.

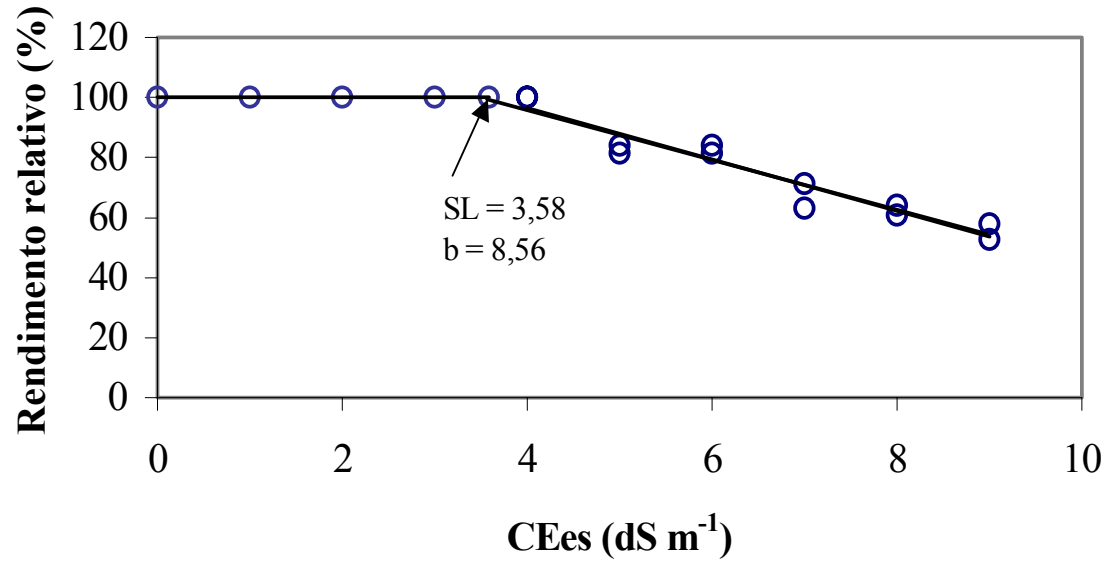

Figura 62 - Curva de tolerância do híbrido de pimentão "Elisa" à salinidade a partir dos resultados obtidos para o solo franco-arenoso

Medeiros (1998) encontrou para cultura do pimentão, híbrido "Luiz", uma salinidade limiar igual a $1,55 \mathrm{dS} \mathrm{m}^{-1}$ e uma perda relativa no rendimento de $11,4 \%$. Entretanto o solo foi salinizado com água de qualidade inferior à base de cloreto de sódio e cálcio, enquanto que no presente experimento a salinidade foi produzida por excesso de fertilizantes, onde os cátions presentes, como maioria, foram o potássio e o cálcio. A menor redução no rendimento relativo da cultura em relação ao encontrado por Maas \& Hoffman (1977) e por Medeiros (1998) pode ser atribuída aos tipos de sais, visto que, o sódio é mais prejudicial que o potássio às plantas, quando acumulados no solo. 
Recomendar um valor de condutividade elétrica na solução do solo como limiar a ser seguido ao longo do ciclo da cultura exige estudos que possibilitem avaliar qual seria o melhor valor para cada fase fenológica, além de que a condutividade elétrica na solução depende da umidade atual do solo e das relação entre os valores de umidade do solo na saturação e na capacidade de campo. Portanto, o valor mais coerente para ser utilizado seria uma extrapolação do valor de CEes limiar após a correção da umidade.

\subsubsection{Ajustamento osmótico do pimentão aos diferentes níveis de salinidade do solo}

Nas Figuras 63, 64, 65 e 66 encontram-se curvas pressão-volume que ilustram a forma de estimativa dos potenciais determinados e seus respectivos valores para folhas do híbrido de pimentão submetido aos níveis extremos de salinidade nos dois tipos de solo estudados. Pode ser verificado que o comportamento das curvas foi semelhante nos dois tipos de solo. Os resultados demonstram que os cuidados tomados durante a coleta das folhas, armazenamento e saturação, permitiram um boa caracterização da curva, sendo possível a verificação da porção linear das curvas encontrando-se bons ajustes aos pontos pertencentes à reta, possibilitando a estimativa dos parâmetros de forma segura.

Os resultados referentes ao tratamento com salinidade inicial no extrato de saturação igual a $9 \mathrm{dS} \mathrm{m}^{-1}$ não estão apresentados em função da problemas técnicos ocorridos durante a realização do teste, ou seja, ocorreu o rompimento do pecíolo de todas as folhas retiradas em campo referente ao tratamento, ocasionado possivelmente por um estrangulamento. 


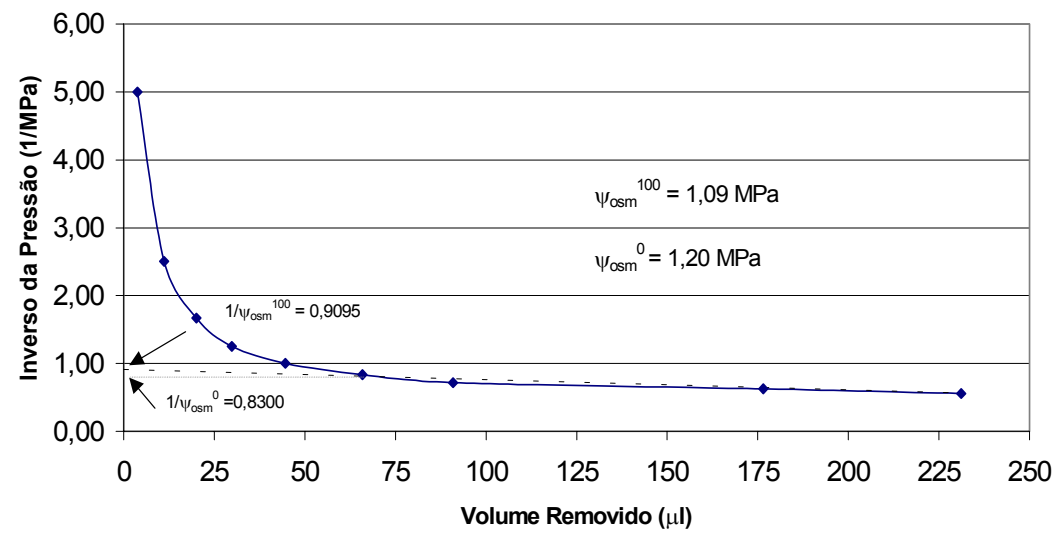

Figura 63 - Curva Pressão volume obtida em folhas provenientes de planta de pimentão cultivada em solo franco-arenoso com salinidade do correspondente a $1 \mathrm{dS} \mathrm{m}^{-1}$

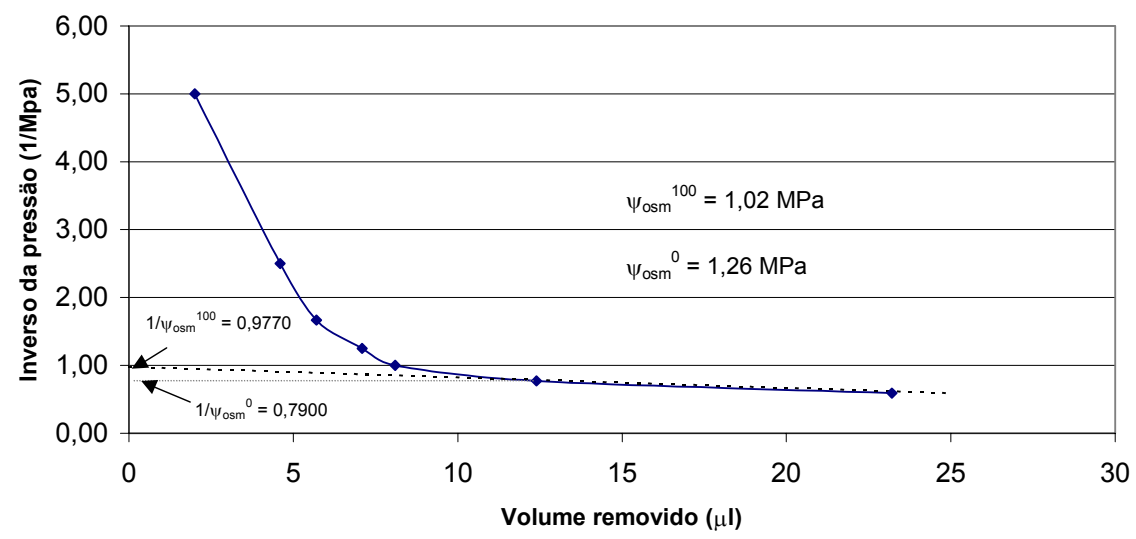

Figura 64 - Curva Pressão volume obtida em folhas provenientes de planta de pimentão cultivada em solo franco-arenoso com salinidade do correspondente a $8 \mathrm{dS} \mathrm{m}^{-1}$ 


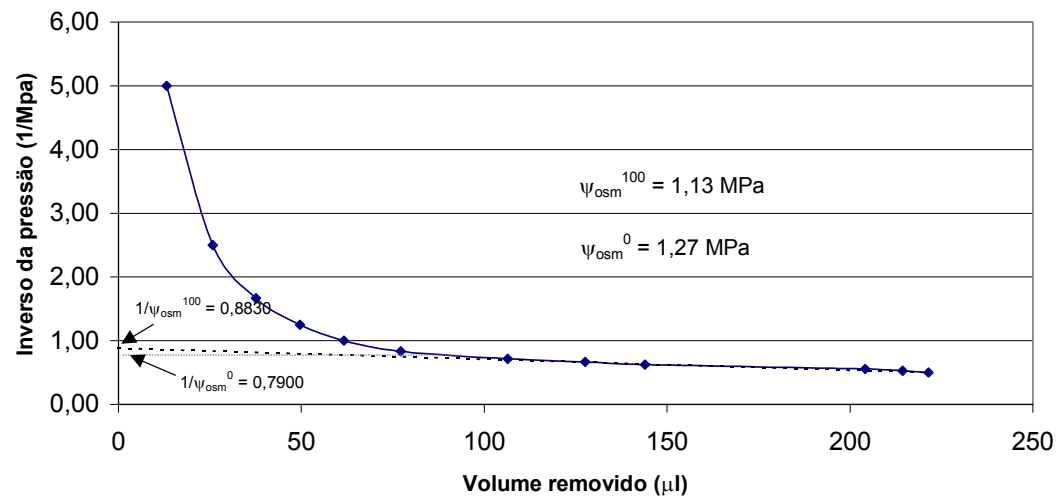

Figura 65 - Curva Pressão volume obtida em folhas provenientes de planta de pimentão cultivada em solo franco-argiloso com salinidade do correspondente a $1 \mathrm{dS} \mathrm{m}^{-1}$

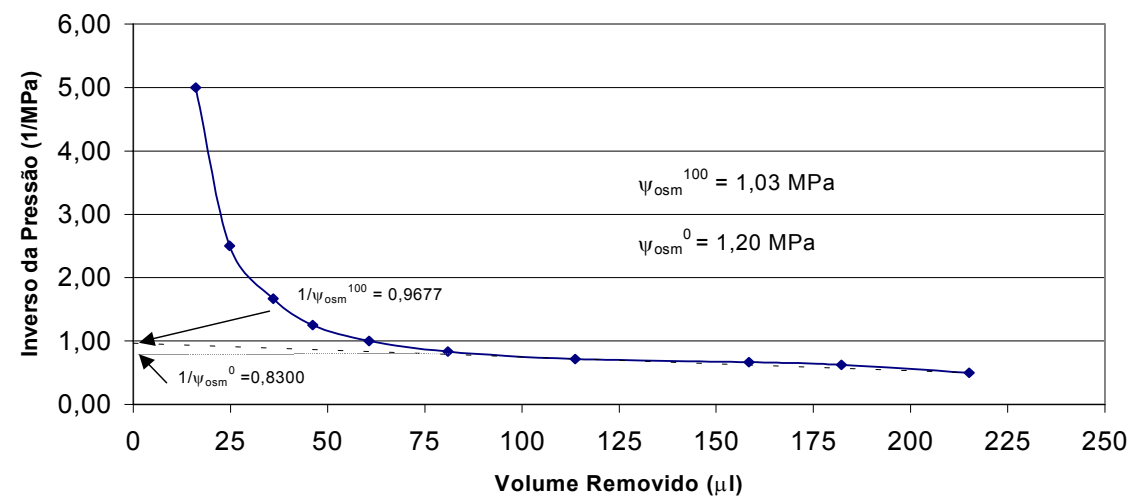

Figura 66 - Curva Pressão volume obtida em folhas provenientes de planta de pimentão cultivada em solo franco-argiloso com salinidade do correspondente a $8 \mathrm{dS} \mathrm{m}^{-1}$

Na Tabela 35 encontram-se os valores de $\psi_{\text {osm }}^{100}$ e $\psi_{\text {osm }}{ }^{0}$ para os tratamentos estudados. Pode ser verificado que os valores de $\psi_{\text {osm }}{ }^{0}$ nos tratamentos do solo franco-argiloso foram ligeiramente superiores em módulo aos encontrados para o solo franco-arenoso, o que pode ser decorrente do fato das curvas referentes às plantas em solo franco-argiloso terem sido determinadas duas semanas após a determinação dos tratamentos em solo franco-arenoso. De maneira geral os valores determinados demonstraram similaridade para ambos os tratamentos, sem ser verificado nenhuma 
tendência de diminuição com o acréscimo do estresse salino, demonstrando a incapacidade da cultura, de acordo com as condições impostas no estudo realizado, de produção e acúmulo de sais no simplasma em resposta ao ambiente salino no qual as plantas foram submetidas no ciclo de crescimento.

Tabela 35. Valores de potenciais osmóticos na turgescência plena $\left(\psi_{\text {osm }}{ }^{100}\right)$ e na turgescência zero $\left(\psi_{\text {osm }}{ }^{0}\right)$ para os tratamentos estudados

\begin{tabular}{ccccc}
\hline $\begin{array}{c}\text { Salinidade do } \\
\text { solo } \\
\left(\mathrm{dS} \mathrm{m}^{-1}\right)\end{array}$ & \multicolumn{2}{c}{ Solo franco-arenoso } & \multicolumn{2}{c}{ Solo franco-argiloso } \\
\hline 1,0 & $\psi_{\text {osm }}{ }^{100}(\mathrm{MPa})$ & $\psi_{\text {osm }}{ }^{0}(\mathrm{MPa})$ & $\psi_{\text {osm }}{ }^{100}(\mathrm{MPa})$ & $\psi_{\text {osm }}{ }^{0}(\mathrm{MPa})$ \\
2,0 & $-1,09$ & $-1,20$ & $-1,13$ & $-1,27$ \\
3,0 & $-1,02$ & $-1,20$ & $-1,10$ & $-1,29$ \\
4,0 & $-1,04$ & $-1,09$ & $-1,11$ & $-1,29$ \\
5,0 & $-1,03$ & $-1,17$ & $-1,02$ & $-1,25$ \\
6,0 & $-1,00$ & $-1,08$ & $-1,13$ & $-1,25$ \\
7,0 & $-1,00$ & $-1,20$ & $-1,05$ & $-1,29$ \\
8,0 & $-1,02$ & $-1,17$ & $-1,00$ & $-1,29$ \\
& $-1,02$ & $-1,26$ & 1,03 & $-1,20$ \\
\hline
\end{tabular}

Os resultados obtidos no presente estudo e de acordo com as condições impostas indicaram que a metodologia empregada para determinação das curvas PV foi adequada. Sendo que, para os níveis de salinidade estudados e texturas de solos utilizados, não ficou evidenciado o ajustamento osmótico das plantas de pimentão em resposta aos diferentes níveis de salinidade do solo impostos. 


\section{CONCLUSÕES}

Com base nos resultados obtidos pode-se concluir que:

- Com o auxílio dos extratores providos de cápsulas cerâmicas é possível determinar a concentração de nitrato e potássio com excelente precisão na solução do solo e cálcio e magnésio com uma menor precisão. Para concentração de enxofre e fósforo a metodologia não é recomendada;

- O uso de testes rápidos na determinação da concentração de nitrato e potássio na solução do solo permite solucionar desequilíbrios nutricionais a partir de monitoramento ao longo do ciclo da cultura, auxiliando assim no manejo da fertirrigação de forma eficiente;

- O monitoramento a partir da condutividade elétrica da solução do solo extraída por cápsulas porosas permite evitar possíveis processos de salinização e deficiências nutricionais;

- A metodologia necessita de calibrações para diferentes culturas e condições de cultivo, sendo assim, é possível recomendar concentrações iônicas apropriadas a cultura implantada;

- O controle da solução do solo em níveis desejados proporcionou um efeito desejável no cultivo do pimentão além de evitar desequilíbrios iônicos;

- Os níveis crescentes de salinidade inicial do solo ocasionaram para o solo francoarenoso uma redução no rendimento da cultura, bem como, nas variáveis vegetativas e no consumo hídrico;

- No solo franco-argiloso ocorreu uma tendência de incremento das variáveis de crescimento e produção com o aumento da salinidade inicial do solo, fato esse atribuído 
à redução do efeito da salinidade inicial sobre as plantas de pimentão, ocasionada possivelmente pela distribuição de sais no solo;

- Os manejos da fertirrigação não proporcionaram efeitos discrepantes nas variáveis relacionadas ao crescimento e produção do pimentão, em virtude da recomendação e marcha de absorção de nutrientes escolhidos para o manejo tradicional adaptar-se bem a extração de nutrientes pela cultura;

- A tolerância da cultura do pimentão à salinidade para o solo franco-arenoso foi superior ao preconizado na literatura, possivelmente esse fato ocorreu em função da distribuição de sais no vaso, ocasionada pela irrigação por gotejamento e aos tipos de sais presentes. 


\section{REFERÊNCIAS BIBLIOGRÁFICAS}

ASSOCIATION OF OFFICIAL AGRICULTURAL CHEMISTS. Official methods of the Association of the Agricultural Chemists. Washington, 1990. v.2, 275p.

ARENAS, M.T.L.; MEJIAS, R.J.; TORRES, F.M. et al. Estimation of the evolution in time of the salts of the soil solution by means of suction cups (compact disc). In: INTERNATIONAL SYMPOSIUM ON WATER QUANTITY AND QUALITY ON GREENHOUSE HORTICUltURE, Almeria, 1996. Proceedings. Almeria: ICIA, ISHS, SECH, 1996.

AYERS, R.S.; WESTCOT, D.W. Water quality for agriculture. Rome: FAO, 1985. 174 p. (FAO. Irrigation and Drainage Paper, 29, Rev. 1).

BAKER, D.E. A new approach to soil testing: II ionic equilibria involving $\mathrm{H}, \mathrm{K}, \mathrm{Ca}$, $\mathrm{Mg}, \mathrm{Mn}, \mathrm{Fe}, \mathrm{Cu}, \mathrm{Zn}, \mathrm{Na}, \mathrm{P}$ and S. Soil Science Society of America Proceedings, v.37, p. 537-541, 1973.

BARBIN, D. Planejamento e análise estatística de experimentos agronômicos. 1. ed. Piracicaba, ESALQ; FEALQ, 1994. 135p.

BAR-YOSEF, B. Fertilization under drip irrigation. In: PALGRAVE, D. A. (Ed.) Fluid fertilizer: science and tecnology. New York: Marcel Dekker, 1991. cap.14, p.285329. (Fertilizer Science and Technology Series, 7). 
BERNSTEIN, L.; FRANCOIS, L.E.; CLARK, R.A. Interactive effects of salinity and fertility on yileds of grains and vegetables. Agronomy Journal, v.66, p.412-421, 1974.

BLANCO, F.F. Tolerância do pepino enxertado à salinidade em ambiente protegido e controle da salinização do solo. Piracicaba, 1999. 104p. Dissertação (Mestrado) Escola Superior de Agricultura “Luiz de Queiroz”, Universidade de São Paulo.

BOHN, H.L.; McNEAL, B.L.; O' CONNOR, G.A. Soil chemistry. New York: John Wiley, 1985. 341p.

BOUYOUCUS, G.J. A recalibration of the hydrometer method for making mechanical analysis of soils. Agronomy Journal, v.43, n.9, p.434-438, 1951.

BOYER, J.S. Measuring the water status of plants and soils. London: Academic Press, 1995. 175p.

BRESLER, E. Two-dimensional transport of solutes during nonsteady infiltration from a trickle source. Soil Science Society of the America Proceedings, v.39, n.4, p.604$613,1975$.

BURGUEÑO, H. La fertirrigacion en cultivos hortícolas com acolchado plástico. Culiacan: BURSAR, 1996. v.1, 45p.

CAMPOS, H. Estatística experimental não-paramétrica. 4. ed. Piracicaba, ESALQ; FEALQ, 1983. 349p.

CRUCIANI, D.E. A drenagem na agricultura. 4. ed. São Paulo: Nobel, 1987. 337p. 
DONEEN, L.D. Salinization of soil by salts in the irrigation water. Transactions of the American Geophysics Union, v. 35, p.943-950, 1975.

DOORENBOS, J.; KASSAM, A. H. Yield response to water. Rome: FAO, 1979. 193p. (FAO. Irrigation and Drainage Paper, 33).

DOORENBOS, J.; PRUITT, W. O. Crop water requirements. Rome: FAO, 1977. 179p. (FAO. Irrigation and Drainage Paper, 24).

ELKHATIB, E.A.; HERN, J.L.; STALEY, T.E. A rapid centrifugation method for obtaining soil solution. Soil Science Society of America Journal, v.51, p.578-583, 1987.

EMPRESA BRASILEIRA DE PESQUISA AGROPECUÁRIA. Serviço Nacional de Levantamento e Conservação do Solo. Manual de métodos de análise de solo. 2.ed. Rio de Janeiro, 1997. 212p.

FAQUIN, V. Nutrição mineral de plantas. Lavras: UFLA, FAEPE, 1994. 227p.

FERNANDES, P.D. Estudo de nutrição mineral do pimentão (Capsicum annuum L.) cultivares Avelar e Ikeda: Absorção e deficiências de macronutrientes. Piracicaba, 1971. 85p. Dissertação (Mestrado) - Escola Superior de Agricultura "Luiz de Queiroz", Universidade de São Paulo.

FURLANI, P.R. Cultivo de alface pela técnica de hidroponia. Campinas: Instituto Agronômico, 1995. 19p. (Boletim Técnico, 55).

GALVÉZ, J.L.; HERNÁNDEZ, J.C.L.; BRETONES, F. et al. Los invernaderos de cubierta asimétrica. HortoFruticultura, n.12, p.30-33, 1993. 
GILLMAN, G.P. A centrifuge method for obtaining soil solution. Melbourne: CSIRO, Division Soil Report, 1976. 16p.

GRATTAN, S.R.; GRIEVE, C.M. Mineral nutrient acquisition and response by plants grown in saline environments. In: PESSARAKLI, M. (Ed.) Plant and crop stress. Tucson: Macel Dekker, 1993. p. 203-226.

GRIEVE, C.M.; SHANNON, M.C.; POSS, J.A. Mineral nutrition of leafy vegetable crops irrigated with saline drainage water. Journal of Vegetable Crop Production, v.7, n.1, p. 37-47, 2001.

GROVER, B.L.; LAMBORN, R.E. Preparation of porous ceramic cups to be used for extraction of soil water having low solute concentrations. Soil Science Society of America Proceedings, v.34, p.706-708, 1970.

HAGIN, J.; TUCKER, B. Fertilization of dryland and irrigated soils. Berlin: Springer - Verlag, 1982. 188p. (Advanced Series in Agricultural Sciences, 12).

HOORN, J.W.; ALPHEN, J.G. Salt movement, leaching efficienty and leaching requirement. Agricultural and Water Management, v.4, p.409-428. 1981.

INSTITUTO ADOLFO LUTZ. Normas analíticas, métodos químicos e físicos para análises de alimentos. 3.ed. São Paulo: Instituto Adolfo Lutz, 1985. v.1, 533p.

KRUGEL, C.; DREYSPRING, C.; HEINZ, W. A new suction apparatus for the complete separation of the soil solution from the soil itself. Superphosphate, v.8, p. 101-108, 1935.

LARCHER, W. Physiological plant ecology. 3.ed. Berlin: Springer - Verlag, 1995. $506 \mathrm{p}$. 
LIMA, L. A. Efeitos de sais no solo e na planta. In: GHEYI, H. R.; QUEIROZ, J. E.; MEDEIROS, J. M. (Ed.) Manejo e controle da salinidade na agricultura. Campina Grande: UFPB,SBEA, 1997. p.113-136.

LIPMAN, C.B. A new method of extracting the soil solution. Journal of Agricultural Science, v.3. p.131-134. 1918.

LOPEZ, C.C. Fertirrigacion : Cultivos hortícolas y ornamentales. 2.ed. Madrid: Mundi Prensa, 2000. 475p.

LOPEZ, C.C. Fertirrigação: aplicações na horticultura. In: FOLEGATTI, M.V.; CASARINI,E.; BLANCO, F.F.; BRASIL, R.P.C.; RESENDE, R.S. (Coord) Fertirrigação: flores, frutas e hortaliças. Guaíba: Agropecuária, 2001. cap. 8, p. 269288.

MAAS, E.V.; HOFFMAN, G.J. Crop salt tolerance - Current Assessment. Journal of Irrigation and Drainage Division ASCE, v.103, n. IR2, p.115-134. 1977.

MAAS, E.V. Crop salt tolerance. In: TANJI, K.K. (Ed.) Agricultural salinity assessment and management manual. New York: ASCE, 1990. cap. 13, p. $262-$ 304.

MAAS, E.V.; GRATTAN, S.R. Crop yields as affected by salinity. In: SKAGGS, R.W.; SCHILFGAARDE, J. Agricultural drainage, agronomy. Madison: SSSA, 1999. cap.3, p.55-108. (Monograph, 38).

MALAVOLTA, E.; VITTI, G.C.; OLIVEIRA, S.A. Avaliação do estado nutricional das plantas: princípios e aplicações. 2.ed. Piracicaba: POTAFOS, 1997. 201p. 
MARFÀ, O. Fertirriego. Revista Sociedad Española de Horticultura, v.68, p. 32-33, 1987.

MARUR, C.J. Curvas pressão - volume e expansão foliar em cultivares de algodoeiro submetidos a déficit hídrico. Scientia Agrícola, v.56, n.3, p.563-569. 1999.

MEDEIROS, J. F.; PEREIRA, F. A. C.; PEREIRA, A. R. et al. Comparação entre a evaporação em tanque classe A padrão e em mini-tanque, instalados em estufa e estação meteorológica. In: CONGRESSO BRASILEIRO DE AGROMETEOROLOGIA, 10, Piracicaba, 1997. Anais. Piracicaba: SBA, 1997. p.228-230.

MEDEIROS, J.F. Manejo da água de irrigação salina em estufa cultivada com Pimentão. Piracicaba, 1998. 152p. Tese. (Doutorado) - Escola Superior de Agricultura "Luiz de Queiroz", Universidade de São Paulo.

MONTEIRO, J. I.; CASTILLA, N.; GUTIERREZ de RAVÉ et al. Climates under plastic in the Almeria area. Acta Horticulturae, n.170, p.227-234, 1985.

MORRISON, R.D.; LOWERY,B. Effect of cup properties, sampler geometry and vacuum on the sampling rate of porous cup samplers. Soil Science, v.149, p.308-316, 1990.

NANETTI, D.C. Nitrogênio e potássio aplicados via fertirrigação na produção, nutrição e pós-colheita do pimentão. Lavras, 2001. 184p. Tese (Doutorado)- Universidade Federal de Lavras.

NORVELL, W.A.; LINDSAY, W.L. Estimation of the concentration of $\mathrm{Fe}^{3+}$ and the $\left(\mathrm{Fe}^{3+}\right)\left(\mathrm{OH}^{-}\right)_{3}$ ion product from equilibria of EDTA in soil. Soil Science Society of America Journal, n.46, p.710-715, 1982. 
OLIVEIRA, A.S. de; SALATI, E. Um estudo sobre as águas subterrâneas da região de Piracicaba. Anais da Escola Superior de Agricultura “Luiz de Queiroz", v.38, p.885-907, 1981.

OR, D. Root zone solute dynamics under drip irrigation : a review. Plant and Soil, v.222, p.163-190, 2000.

PAKER, F.W. Methods of studying the concentration and composition of the soil solution. Soil Science, v. 12, p.209-232, 1921.

PAPADOPOULOS, I. Fertirrigação: situação atual e perspectivas para o futuro. In: FOLEGATTI, M.V. (Coord) Fertirrigação : citrus flores e hortaliças. Guaíba: Ed. Agropecuária, 1999. cap.1, p.11-84.

PEREIRA, F.A.M; FERNÁNDEZ MEDINA, B.; ETCHEVERS,J.D. et al. Solos afetados por sais no Nordeste I : Efeito da relação solo-água nos valores de condutividade elétrica. Agropecuária Técnica, Areia, v.2, p.148-154, 1981.

PEREIRA, A. R. P.; VILLA NOVA, N. A.; SEDIYAMA, G. C. Evapo(transpi)ração. Piracicaba: FEALQ, 1997. 183 p.

QUEIROZ, J.E.; GONÇALVES, A.C.; SOUTO, J.S. et al. Avaliação e monitoramento da salinidade do solo. In: GHEYI, H.R., QUEIROZ, J.E, MEDEIROS, J.F. (Ed.) Manejo e controle da salinidade na agricultura irrigada. Campina Grande: SBEA. 1997. cap.3, p.69-111.

REEVE, R.C.; DOERING, E.J. Sampling the soil solution for salinity appraisal. Soil Science, n.99, p.339-344, 1965. 
RHOADES, J.D. Eletrical conductivity methods for measuring and mapping soil salinity. Advances in Agronomy, v. 49, p.201-251, 1994.

RHOADES, J.D.; CHANDUVI, F.; LESCH, S. Soil salinity assessment: methods and interpretation of electrical condutivity measurements. Rome: FAO, 1999. 150p. (FAO. Irrigation and Drainage Paper, 57).

RHOADES, J.; KANDIAH, A.; MASHALI, A. M. Uso de águas salinas para produção agrícola. Trad. de H.R. GHEYI, J.R. SOUZA e J.E. QUEIROZ. Campina Grande: UFPB, 2000. 117p. (FAO. Estudos de Irrigação e Drenagem, 48).

RHOADES, J.D.; LOVEDAY, J. Salinity in irrigated agriculture. In: STEWART, D.R.; NIELSEN, D.R. (Ed.) Irrigation of agricultural crops. Madison: ASA, CSSA, SSSA, 1990. cap.36, p. 1089-1142. (Agronomy, 30)

RICHARDS, L.A. A pressure-mebrane extraction apparatus for soil solution. Soil Science, v.51, n.5, p.377-386, 1941.

RICHARDS, L.A.. Methods for mounting porous plates used in soil moisture measurement. Agronomy Journal, n.41, p.489-490, 1949.

RICHARDS, L.A. (Ed.) Diagnosis and improvement of saline and alkali soils. Washington: United States Salinity Laboratory, 1954. 160p. (USDA. Agriculture Handbook, 60).

RIGA, P.; CHARPENTIER, S. Ionic-equilibrium time inside ceramic cups in unsaturated porous media. Soil Science Society of America Journal, v.62, p.574579, 1998. 
ROSS, D.S.; BARTLETT, R.J. Effects of extraction methods and sample storage on properties of solutions obtained from forested spodosols. Journal of Environmental Quality, n.19, p.108-113, 1990.

SANTOS,R.V.dos; MURAOKA,T. Interações salinidade e fertilidade do solo. In: GHEYI, H. R.; QUEIROZ, J. E.; MEDEIROS, J. M. (Ed.) Manejo e controle da salinidade na agricultura. Campina Grande: UFPB, SBEA, p.289-315, 1997.

SERRANO, L.; CARBONELL, X.; MARFÀ, O. et al. Nitrate leaching and strawberry production as affected by drip irrigation. Enviromental Pollution, v.2, p. 311-316, 1993.

SHALHEVET, J. Using water of marginal quality for crop production: major issues. Agricultural and Water Management, v.25, p. 233-269, 1994.

SCHOLANDER, P.F.; HAMMEL, H.T.; BRADSTREET, E.D. et al. Sap pressure in vascular plants. Science, v.148, p.339-346, 1965.

SILVA, E.F.F.; MIRANDA, J.H.; COELHO, R.D. et al. Determinação da salinidade do solo utilizando extratores de cápsulas porosas e soluções diluídas. (compact disc). In: CONGRESSO BRASILEIRO DE ENGENHARIA AGRÍCOLA, 28 , Pelotas, 1999. Anais. Pelotas, 1999. Pelotas: SBEA, 1999.

SILVA, E.F.F.; ANTI, G.R.; CARMELLO, Q.A.C. et al. Extratores de cápsulas porosas para o monitoramento da condutividade elétrica e do teor de potássio na solução de um solo. Scientia Agricola, v.57, p.785-789, 2000.

SILVA, E.F.F.; CAMARGO, M.S.; DUARTE, S.N. et al. Extratores providos de cápsula cerâmica e a determinação do nitrato solúvel num solo cultivado com aster (compact disc). In: CONGRESSO BRASILEIRO DE ENGENHARIA AGRÍCOLA, 29 , Fortaleza, 2000. Anais. Fortaleza: SBEA, 2000. 
SMEDEMA, L.K. Water table control indices for drainage of agricultural land in humid climates. Agricultural Water Management, v.14, n.1, p.69-77, 1988.

SONNEVELT, C.; ENDE, J. Soil analysis by means of a 1:2 volume extract. Plant Soil, v.35, p.505-516, 1971.

SOUSA, V.F.; SOUZA, A.P. Fertirrigação II: Tipos de produtos, aplicação e manejo. Irrigação e Tecnologia Moderna, v.47, p.15-20, 1992.

SOUSA, V.F.; SOUZA, A.P. Fertirrigação: princípios e métodos de aplicação, vantagens e limitações. In: CONGRESSO BRASILEIRO DE ENGENHARIA AGRÍCOLA, 22 , Ilhéus, 1993. Anais.Ilhéus: SBEA, 1993. p.2519-2528.

SPOSITO, G. The future of an illusion : Ion activities in soil solutions. Soil Science Society of America Journal, v.48, p.531-536, 1984.

STANGHELLINI, C. Evapotranspiration in greenhouse with special reference to mediterranean conditions. Acta Horticulturae, n.335, p.296-304, 1993.

TANJI, K.K.(Ed.) Agricultural salinity assessment and management. New York : ASCE, 1990. 610p. (ASCE Manuals and Reports of Engineering Pratices, 71).

TIVELLI, S.W. A cultura de pimentão. In: GOTO R.; TIVELLI, S.W. (Org.) Produção de hortaliças em ambiente protegido: condições subtropicais. São Paulo: Fundação Editora da UNESP, 1998. p.225-257.

TIVELLI, S.W. Avaliação de híbridos e sistemas de condução na cultura do pimentão (Capsicum annumm L.) vermelho em ambiente protegido. Botucatu, 1999. 240p. Tese. (Doutorado) - Universidade Estadual Paulista "Júlio de Mesquita Filho". 
VILLAS BOAS, R.L.; BOARETO, A. E.; VITTI, G. C. Aspecto da fertirrigação. In: VITTI, G. C.; BOARETO, A. E. (Ed.) Fertilizantes fluidos. Piracicaba: POTAFOS,1994. cap.15, p. 283-308.

VILLAS BOAS, R.L.; BÜLL, L;T.; FERNANDES, D.M. Fertilizantes em fertirrigação. In: FOLEGATTI, M.V. (Coord) Fertirrigação : citrus flores e hortaliças. Ed. Guaíba: Agropecuária, 1999. cap.4, p.293-334.

VILLAS BOAS, R.L. Doses de nitrogênio para o pimentão aplicadas de forma convencional e através da fertirrigação. Botucatu, 2001. 123p. Tese. (Livre Docência) - Universidade Estadual Paulista "Júlio de Mesquita Filho".

VITTI, G. C.; BOARETO, A. E.; PENTEADO, S. R. Fertilizantes e fertirrigação. . In: VITTI, G. C.; BOARETO, A. E. (Ed.) Fertilizantes fluidos. Piracicaba: POTAFOS, 1994. cap.14, p.261-281.

VIVANCOS, D. A. Fertirrrigation. Madrid: Mundi-Prensa, 1993. 217p.

WILLMOTT, C.J. On the validation of models. Physical Geography, v.2, p.184-194, 1981.

WOLT, J.D. Soil solution chemistry :applications to environmental science and agriculture. New York : Wiley, 1994. 345 p.

WOLT, J.D.; RHODES, G.N.; GRAVEEL, J.G. et al. Activity of imazaquin in soil solution as affected by incorporated wheat (Triicum aestivum) straw. Weed Science, v.37, p.254-258, 1989. 